\title{
17. CENOZOIC DIATOMS FROM THE NORTHEAST PACIFIC, LEG 18
}

Hans-Joachim Schrader, Geologisch-Paläontologisches Institut und Museum der Universität Kiel, Germany

\section{CONTENTS}

Introduction

Preparation of samples and presentation of results

Diatoms at each site (abundance, preservation, biostratigraphic zonation, paleoclimatical interpretation)

Site 172

Site 173

Site 174

Site 175

Site 176

Site 177

Site 178

Site 179

Site 180

Site 181

Site 182

Time ranges of selected taxa and biostratigraphic zonation

Correlation with other Pacific sections

Systematic section

Paleoclimatic interpretation '

Site 173

Site 175

Site 176

Site 177

Site 178
Page

673

674

674

674

674

675

675

675

682

682

682

687

687

687

687

701

701

713

713

714

714

714

714
Site 179

Site 180

Site 181

Site 182

Correlation of the Td-values with results of Donahue (1970), Kanaya and Koizumi (1966), and Jouse (1971)

Correlation and comments on Rhabdonema arcuatum Zones

Sedimentological interpretation (depth, reworking, influx of terrigenous material, influx of marine-littoral material)

Site 173

Site 174

Site 175

Site 176

Site 177

Site 178

Site 179

Site 180

Acknowledgements

References

Appendix: Tables of abundance, preservation, number of individuals, and Td-values at each site

Plates
Page

714

714

715

715

715

715

715

716

716

716

716

716

717

717

717

717

717

736

745

\section{INTRODUCTION}

Most of the drilling sites of Leg 18 of the Deep Sea Drilling Project contained diatoms together with silicoflagellates, radiolarians, and sponge spicules. Site localities are as follows:

Site 172 : $31^{\circ} 32.23^{\prime} \mathrm{N}, 133^{\circ} 22.36^{\prime} \mathrm{W}$, water depth 4768 meters.

Site 173 : $39^{\circ} 57.71^{\prime} \mathrm{N}, 125^{\circ} 27.12^{\prime} \mathrm{W}$, water depth 2927 meters.

Site 174: $44^{\circ} 53.38^{\prime} \mathrm{N}, 126^{\circ} 20.80^{\prime} \mathrm{W}$, water depth 2815 meters.

Hole $174 \mathrm{~A}: 44^{\circ} 53.38^{\prime} \mathrm{N}, 126^{\circ} 21.40^{\prime} \mathrm{W}$, water depth 2799 meters.

Site 175 : $44^{\circ} 50.20^{\prime} \mathrm{N}, 125^{\circ} 14.50^{\prime} \mathrm{W}$, water depth 1999 meters.

Site $176: 45^{\circ} 56.00^{\prime} \mathrm{N}, 124^{\circ} 37.00^{\prime} \mathrm{W}$, water depth 193 meters.

Site 177: $50^{\circ} 28.18^{\prime} \mathrm{N}, 130^{\circ} 12.30^{\prime} \mathrm{W}$, water depth 2006 meters.

Site 178 : $^{\prime} 56^{\circ} 57.38^{\prime} \mathrm{N}, 147^{\circ} 07.86^{\prime} \mathrm{W}$, water depth 4218 meters.

Site 179: $56^{\circ} 24.54^{\prime} \mathrm{N}, 145^{\circ} 59.32^{\prime} \mathrm{W}$, water depth 3781 meters.

Site 180 : $57^{\circ} 21.76^{\prime} \mathrm{N}, 147^{\circ} 51.37^{\prime} \mathrm{W}$, water depth 4923 meters.

Site 181: $57^{\circ} 26.30^{\prime} \mathrm{N}, 148^{\circ} 27.88^{\prime} \mathrm{W}$, water depth 3086 meters.

Site 182 : $57^{\circ} 52.96^{\prime} \mathrm{N}, 148^{\circ} 42.99^{\prime} \mathrm{W}$, water depth 1419 meters.

Hole $182 \mathrm{~A}: 57^{\circ} 52.88^{\prime} \mathrm{N}, 148^{\circ} 43.39^{\prime} \mathrm{W}$, water depth 1434 meters.

Lower Miocene floras were encountered only at Site 173; Middle and Upper Miocene floras at Sites 173 and 178; Pliocene floras at Sites 173, 177, 178, and 179; and Pleistocene diatom floras at Sites 173, 174, 175, 176, 177, 
$178,179,180,181$, and 182. The Miocene and Pliocene portions of these sequences produced significant diatom stratigraphic results (correlation with diatom zonation of the Equatorial Pacific, Burckle, 1972; of the Oga Peninsula, Japan, Koizumi, 1968; of the Experimental Mohole Drilling, Guadalupe Suite, Kanaya, 1971, Schrader, 1973, in press; and of Kamchatka Sequences, Jousé, SheshukovaPoretskaya, 1967).

Sedimentological, paleoecological, and paleoclimatical data are briefly summarized and nearly all diatom taxa for which a good description is unavailable are treated systematically and illustrated.

\section{PREPARATION OF SAMPLES AND PRESENTATION OF RESULTS}

Samples were taken aboard Glomar Challenger for Sites 172 and 173 at fixed intervals, and as a result may be unequally spaced through time. This method of sampling proved unsatisfactory in turbidite and hemipelagic sediment-bearing sequences of the other sites. Here, several smear slides were prepared from each section in order to determine where shore laboratory samples should be taken. In all cases, the attempt was made to sample as complete a sequence of the pelagic and hemipelagic diatom-bearing sediments as possible.

Fractions coarser than $43 \mu$ were prepared aboard ship by splitting the samples prepared for radiolarians. Counts were made on these samples to determine the qualitative composition of marine-pelagic, marine-littoral, and freshwater diatoms, and the abundance of sponge spicules.

Shore laboratory samples were treated as follows: $0.2 \mathrm{ml}$ of crude material was pipetted from each sample tube and heated at $100^{\circ} \mathrm{C}$ for 20 minutes in a beaker with a mixture of concentrated acetic acid and hydrogen peroxide. This suspension was then centrifuged in 50-ml centrifuge tubes (11 cm in height, $4 \mathrm{~cm}$ in diameter) at 1700 r.p.m., decanted, and the residue diluted with demineralized water. This procedure was repeated seven times. The residue was then carefully shaken in a mixture of $0.5 \%$ sodium pyrophosphate in water and centrifuged three times. The residue was then diluted to $50 \mathrm{ml}$ with demineralized water and, after a few drops of formalin were added to prevent bacterial activity, stored in plastic bottles. Each sample was carefully shaken, 3 drops were pipetted from the middle of the bottle and put on an $18 \times 18 \mathrm{~mm}$ cover glass. After drying, a small amount of Aroclor (solvent xylene, No. 4465 [Schrader, 1969], nd 1,66) was placed on the cover glass and heated until the medium became hard upon cooling. The cover glass was then taken up on a heated slide. This method of sample preparation resulted in a standard amount of original material on each slide.

Estimates of relative abundance of diatom species were made by random counts of 100 or 200 individuals on a traverse across the slide.

Td values used for paleoclimatic interpretations are defined by Kanaya and Koizumi (1966) as

$$
T d=\frac{T_{w} \times 100}{T_{w}+T_{c}}
$$

where $\mathrm{T}_{w}$ is the number of warm-water species and $\mathrm{T}_{c}$ is the number of cold-water species. A microscope field of $250 \mu$ was used for counting the Td values. Only specimens represented by more than half a frustule were counted as one specimen.

Two methods were used to gather the data on quantitative abundances of diatom frustules. In Method $A$, used only at Site 173, twenty microscopic fields of $120 \times 185 \mu$ were orientated diagonally over the cover glass and each diatom valve represented by more than one half was counted as one individual (Leitz Orthoplan Obj. Oil $57 / 0.95$, Oc. Periplan GW 10). Data are presented as relative abundances of diatom valves within one field. In Method $B$, used at all other sites, all frustules represented by more than one half, occurring within one traverse measuring $250 \times 1800 \mu$, were counted. A traverse was laid through the middle of the cover glass. Data are presented as the number of valves per single traverse.

Abbreviations in the tables are a minus sign (-), indicating not present; $R$, rare (only a very few individuals on one slide); $F$, few (several individuals per slide); $C$, common; and $A$, abundant.

Estimates of preservation are based on the presence or absence of special diatom species which either resist dissolution or are dissolved in the sediment very easily (Schrader, 1972). The abundance of Coscinodiscus marginatus and the condition of valves are used as evidence of the degree of diatom dissolution. Large numbers of Denticula seminae and related forms are used as evidence of good preservation of diatom tests within the sediment. Abbreviations for preservation in the tables are $G$, good; $M$, moderate; and $P$, poor.

Reworked species are marked with a circle in the tables.

\section{DIATOMS AT EACH SITE (ABUNDANCE, PRESERVATION, BIOSTRATIGRAPHIC ZONATION, PALEOCLIMATIC INTERPRETATION)}

\section{Site $\mathbf{1 7 2}$}

Diatoms are nearly absent in all cores from the sea floor to a depth of about 24 meters (172-3, CC). In Core 1, only the core catcher contained specimens (Coscinodiscus marginatus, Coscinodiscus radiatus, and Ethmodiscus rex) in the acid-cleaned fraction coarser than $63 \mu$. These specimens were corroded (no outer or inner sieve membranes; pore margins zig-zag) and fragmented. All these species have wide biostratigraphic ranges and resist dissolution. Attempts to find evidence of near-surface dissolution and/or corrosion gradients in opaline diatom frustules by sampling at $5-\mathrm{cm}$ intervals down to $50 \mathrm{~cm}$ in Core 1 , Section 1 failed for lack of frustules. This indicates that no real surface layer $(0-50 \mathrm{~cm}$ below the sea floor) was recovered; at least some of the larger species should have been found within that interval.

\section{Site 173}

Diatoms are common to abundant and moderately to well preserved in the terrigenous muds cored continuously from the surface to about 130 meters below the sea floor. They are abundant and well preserved in the diatomites and diatom-bearing muds from 130 meters to 280 meters below 
the sea floor. The sample from Sample 31-1(132-134 cm) contained a moderately preserved assemblage. The section from 282 meters to 333.5 meters is barren of diatoms. The sequence from 0 to 281 meters represents a continuous record of high diatomaceous productivity from today to the Lower Miocene with an abruptly increased influx of terrigenous material within the Pleistocene and Late Pliocene. Several cool and warm periods are revealed by warm-, temperate-, and cool-water diatom biofacies (for more details see "Paleoclimatic Interpretations," this report). Older reworked microfossils are common in the Pleistocene section and in the lower section of the hole. In the latter interval, Holocene to Pleistocene forms were displaced to this depth by downslumping or downwashing during coring procedures. The abundance of displaced (littoral marine, freshwater benthic and planktonic) diatoms increased abruptly in the terrigenous Pleistocene muds. Detailed references to the systematic composition of the diatom floras are given in Table 1 and in discussion of biostratigraphy ("Time Ranges of Selected Taxa and Biostratigraphic Zonation," this report).

The base of NPD Zone $I$ is at 17 meters (173-2-2, 104-105 cm), the base of NPD Zone II at 28 meters $(173-4-2,55-56 \mathrm{~cm})$, the base of NPD Zone III at 53 meters $(173-6-3,55-56 \mathrm{~cm})$, the base of NPD Zone IV at 67 meters (173-8-2, 55-56 cm), the base of NPD Zone V at 77 meters $(173-9-4,55-56 \mathrm{~cm})$, the base of NPD Zone VI at 90 meters $(173-10-5,55-56 \mathrm{~cm})$, the base of NPD Zone VII at 104 meters $(173-12-2,55-56 \mathrm{~cm})$, the base of NPD Zone VIII at 123 meters $(173-14-1,55-56 \mathrm{~cm})$, the base of NPD Zone IX at 130 meters (173-14, CC), the base of NPD Zone X at 139 meters (173-15, CC), the base of NPD Zone XI at 152 meters $(173-17-2,55-56 \mathrm{~cm})$, the base of NPD Zone XII at 160 meters $(173-17, \mathrm{CC})$, the base of NPD Zone XIII at 168 meters $(173-18-4,56-57 \mathrm{~cm})$, the base of NPD Zone XIV at 173 meters $(173-19-2,55-56 \mathrm{~cm})$, the base of NPD Zone XV at 177 meters $(173-20-2,55-56 \mathrm{~cm})$, the base of NPD Zone XVI at 182 meters $(173-21-1,99-100 \mathrm{~cm})$, the base of NPD Zone XVII at 197 meters (173-22-2, 55-56 $\mathrm{cm}$ ), the base of NPD Zone XVIII at 205 meters (173-23-1, $110-122 \mathrm{~cm}$ ), the base of NPD Zone XIX at 225 meters (173-24, CC), the base of NPD Zone XX at 234 meters $(173-25, \mathrm{CC})$, the base of NPD Zone XXI at 244 meters (173-26, CC), the base of NPD Zone XXII at 254 meters $(173-27$, CC), the base of NPD Zone XXIII at 164 meters $(173-29-1,55-56 \mathrm{~cm})$, and the base of NPD Zone XXIV at 281 meters $(173-30, \mathrm{CC})$; the base of NPD Zone XXV has not been defined.

No breaks in the diatom stratigraphic record were detected from 0 to 281 meters. The species diversity changed noticeably between cool and warm biofacies. Within sections representing the cool biofacies, diversity was low; in warm-interval sections, diversity was high. Based 'on placement of the base of North Pacific Diatom Zone IV (Pleistocene-Pliocene boundary) at 67 meters, the base of NPD Zone XI (Pliocene-Miocene boundary) at 152 meters, and on other horizons with absolute ages estimated on the basis of Berggren's (1969) correlations with the radiometric-paleomagnetic time scale, the interval from 0 to 120 meters below the surface (Pleistocene-Late Pliocene has a sedimentation rate of $44 \mathrm{~m} / \mathrm{m} . \mathrm{y}$. and the interval from
140 meters to 281 meters below the surface (Middle Pliocene-Early Miocene) has an extrapolated sedimentation rate of $10.5 \mathrm{~m} / \mathrm{m} . \mathrm{y}$. (Figure 35 ).

\section{Site 174 (Holes 174 and 174A)}

Diatoms are abundant only in the uppermost part of Hole 174 (174-1, CC). Both abundance and preservation are low. The thanatocoenoses in the lower part of this hole consist of displaced large, robust freshwater and marine benthic species. A few diatom frustules occur sporadically in Hole 174A. Preservation varies from sample to sample. The occurrences of diatoms are correlated with radiolaria and sponge spicules. No species of known stratigraphic importance was encountered.

\section{Site 175}

Diatoms are common in the upper part of Site 175 to a depth of about 100 meters below the sea floor (175-10-3, $78-79 \mathrm{~cm}$ ); they are less abundant in the lower part from 100 to 180 meters below the sea floor (175-21-1, 65-66 $\mathrm{cm})$. The interval from 180 to 220 meters $(175-21-2,30 \mathrm{~cm}$ to $175-22, \mathrm{CC}$ ) contained only a very few frustules. Several cool periods can be recognized in the Pleistocene section by warm; temperate-, and cold-water diatom assemblages (for more details see "Paleoclimatic Interpretations," this report). The abundance of older reworked microfossils (Pliocene) was low within this section. Sporadic displacement of marine littoral species occurred throughout the hole. Detailed references on the content of diatom taxa are given in Table 2.

The base of NPD Zone I is at 51.5 meters (175-6-6, $87-89 \mathrm{~cm}$ ) and the base of NPD Zone II at 147.5 meters $(175-16, \mathrm{CC})$; the base of NPD Zone III has not been found. No breaks in the diatom stratigraphic record were detected from 0 to 188 meters below the sea floor. The species diversity was high in all diatom-bearing samples. The oldest penetrated diatom-bearing sediment, at 188 meters $(175-21-2,65-66 \mathrm{~cm})$, represents NPD Zone III with an absolute age of 0.92 to 1.3 m.y.

Based on the placement of North Pacific Diatom Zone I (base at $51.5 \mathrm{~m}$ ) and NPD Zone II (base at $147.5 \mathrm{~m}$ ), a sedimentation rate of $18 \mathrm{~cm} / 10^{3} \mathrm{y}$ was derived (Figure 36).

\section{Site 176}

Diatoms are abundant and well preserved in the uppermost samples of Site $175(176-1-1,65-66 \mathrm{~cm})$, but numbers of individuals and preservation of tests decreases with depth. Samples from Core $5(176-5, \mathrm{CC})$ contain only a few frustules of thick-walled species.

The continuously cored section of dark greenish gray soft carbonate-bearing mud from about 0 to 35 meters below the sea floor (176-1-1, 65-66 $\mathrm{cm}$ to $176-5-2,65-66$ $\mathrm{cm})$ represents NPD Zone I with an absolute age of 0 to 0.26 m.y. The lower section from 35 to 41 meters below the sea floor represents NPD Zone II with an absolute age of 0.25 to 0.92 m.y. (176-5-3, 63-64 $\mathrm{cm}$ to $176-5-6,66-67$ $\mathrm{cm})$. Oldest recovered sediment belongs to NPD Zone III. Based on the placement of NPD Zone I and II, the sedimentation rate was approximately $65 \mathrm{~m} / \mathrm{m} . \mathrm{y}$. (Figure 36). 
TABLE 1

Diatoms at Site 173

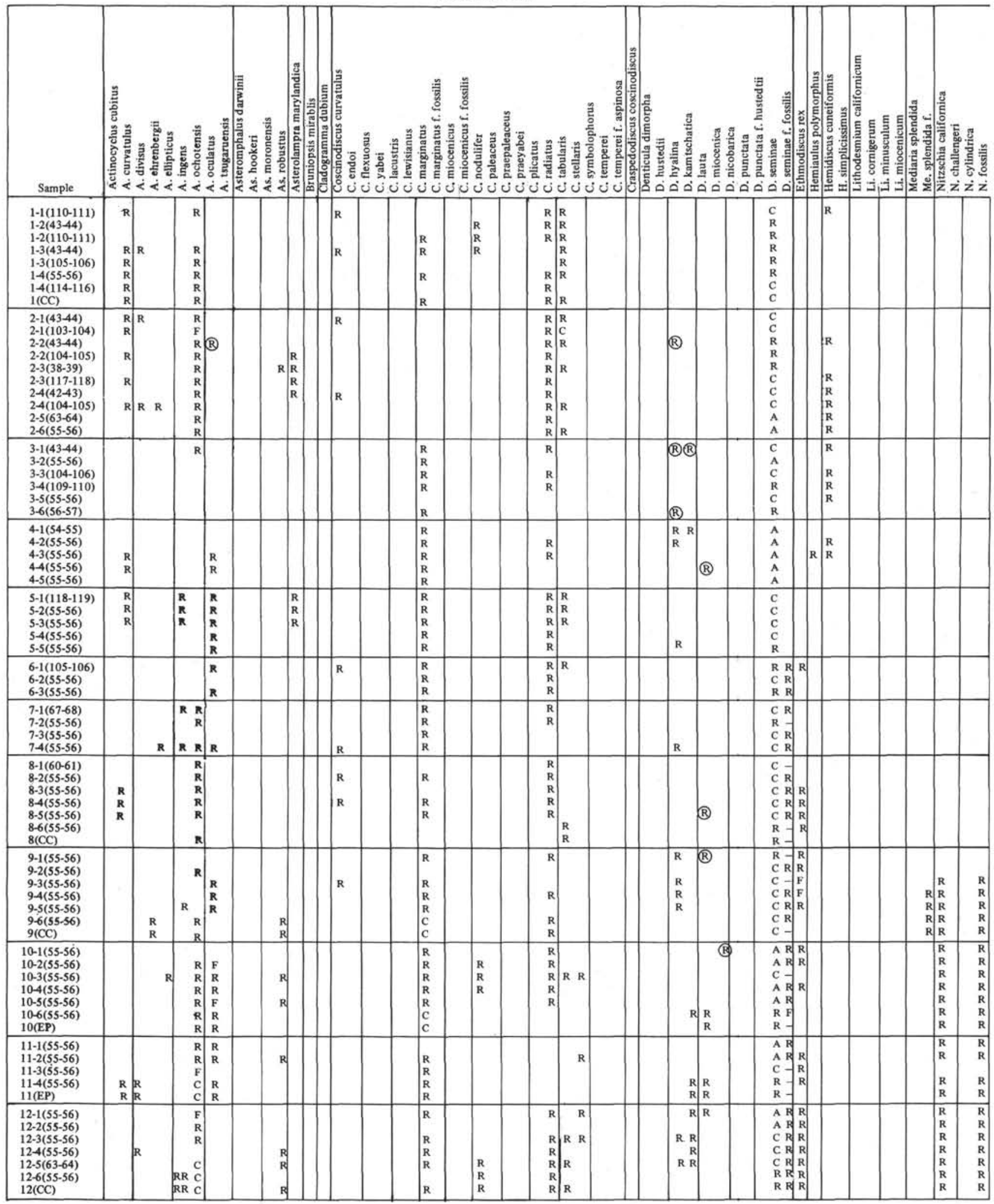


TABLE 1 - Continued

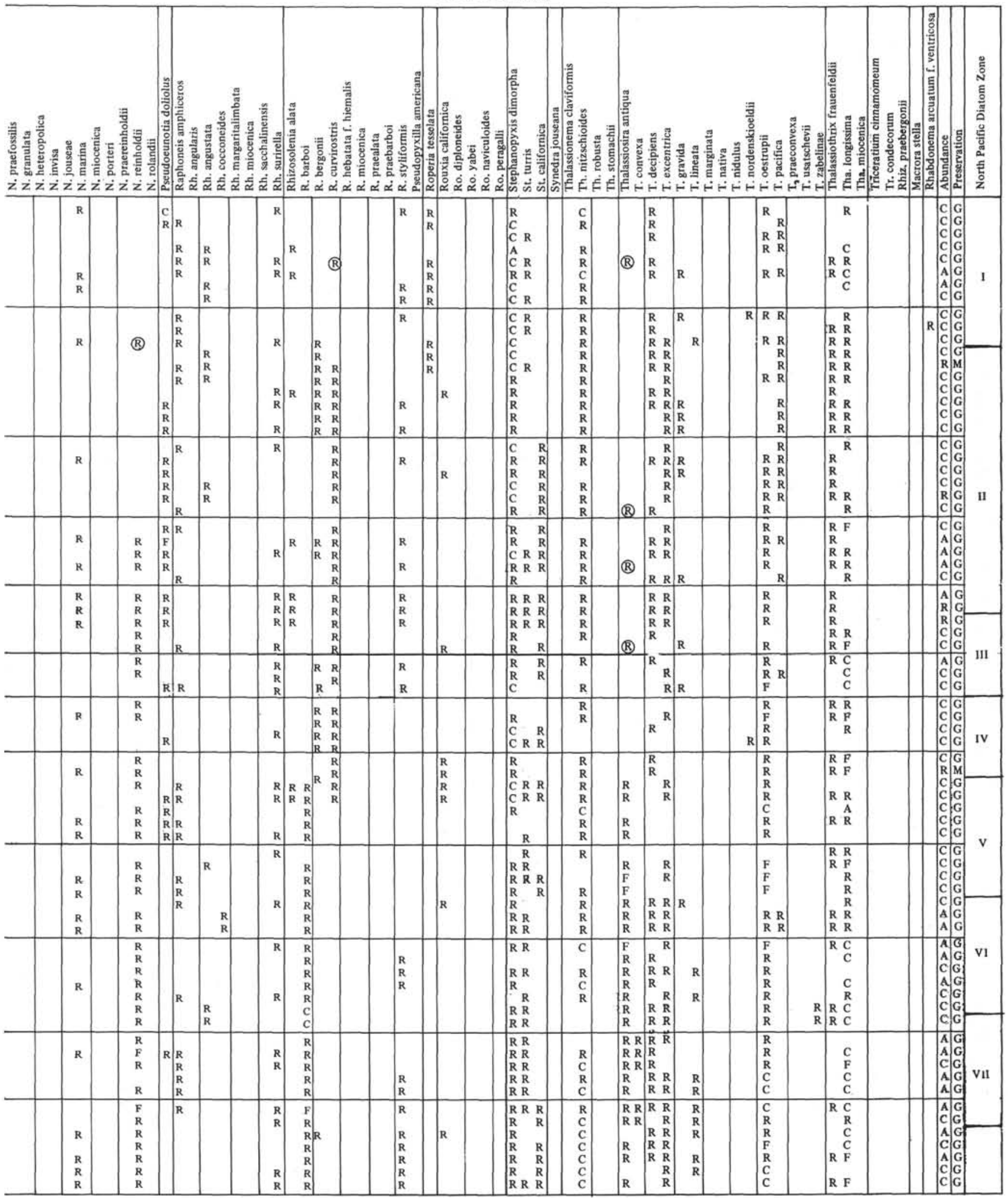


TABLE 1 - Continued

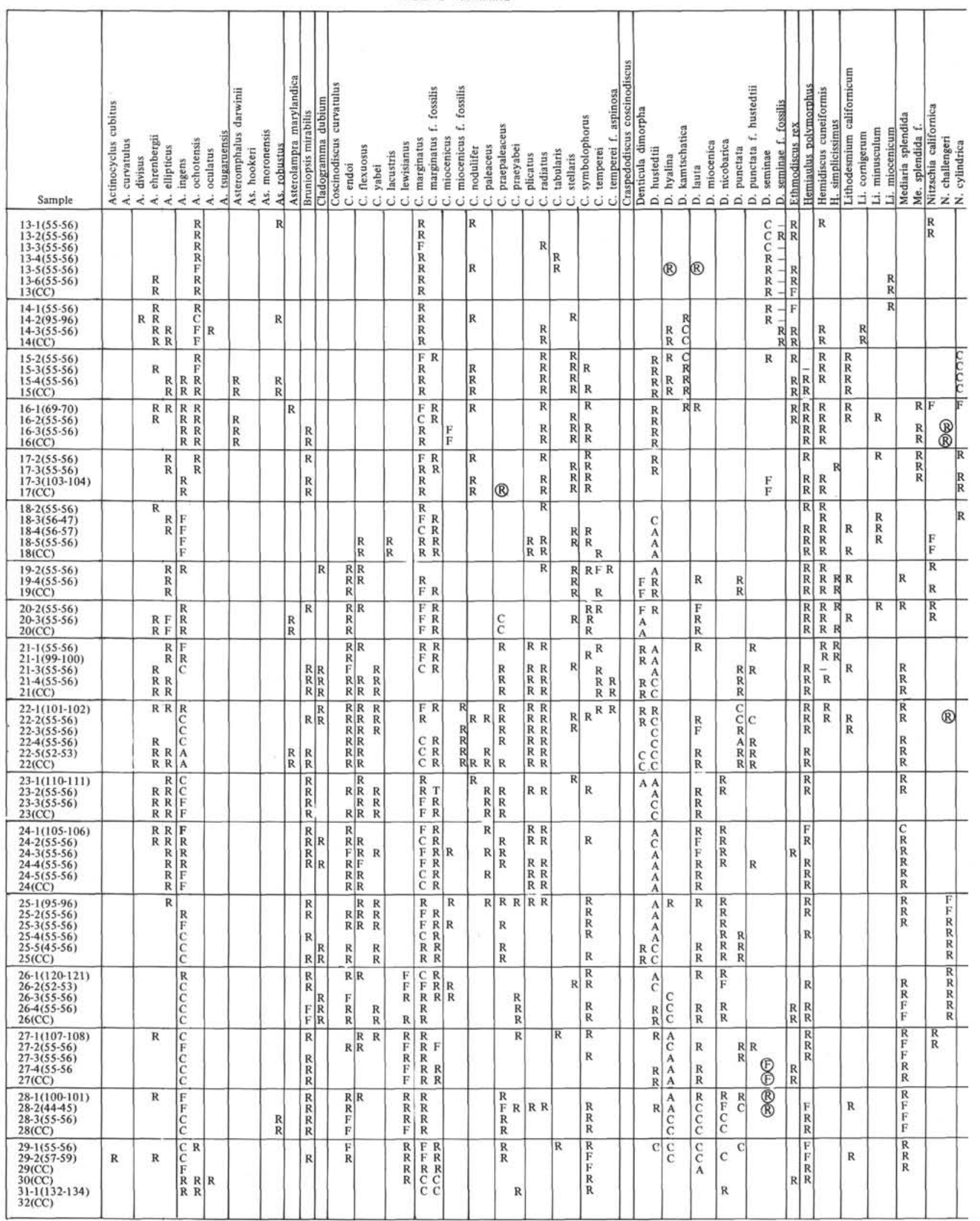


TABLE 1 - Contimued

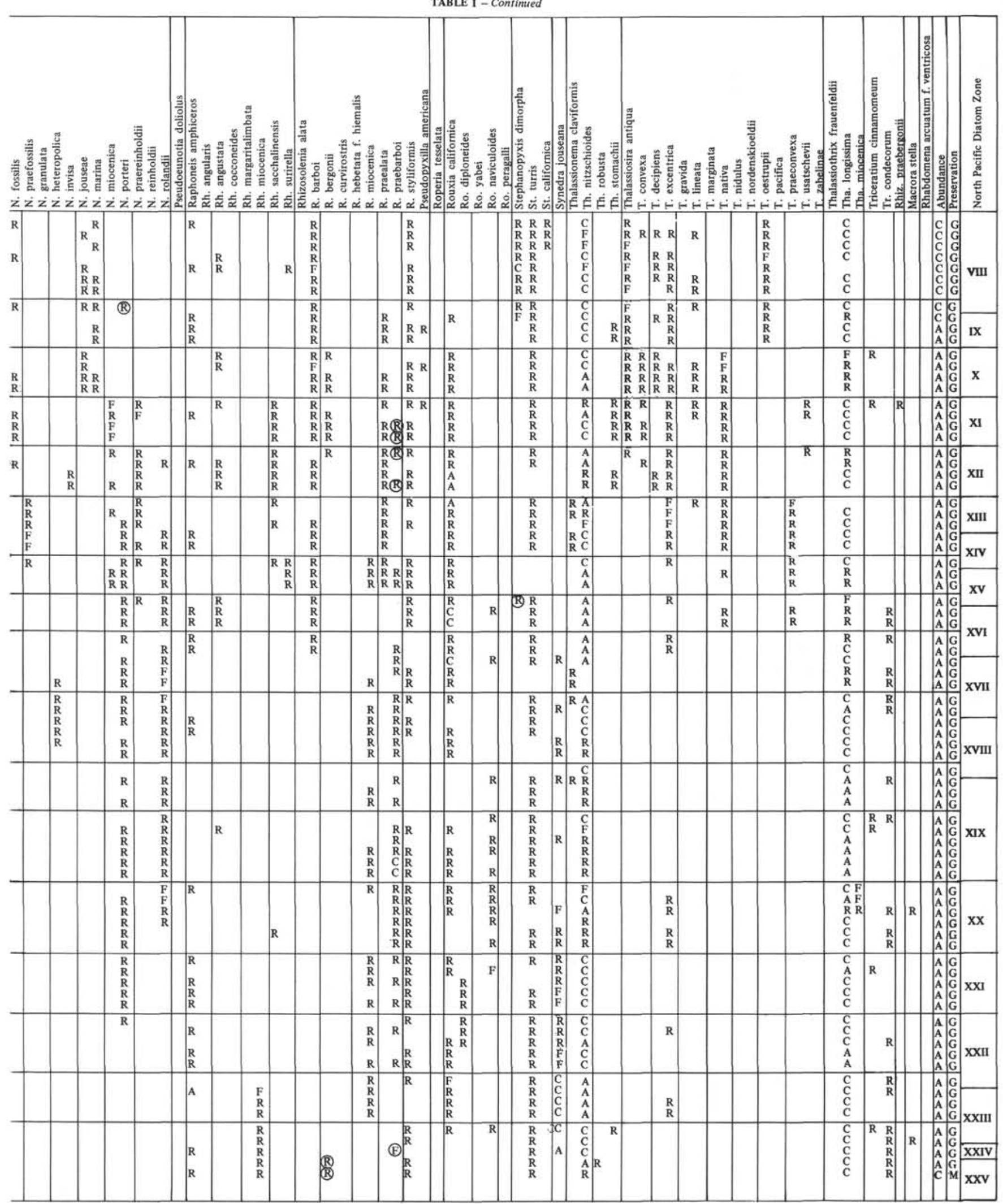


TABLE 2

Diatoms at Site 175

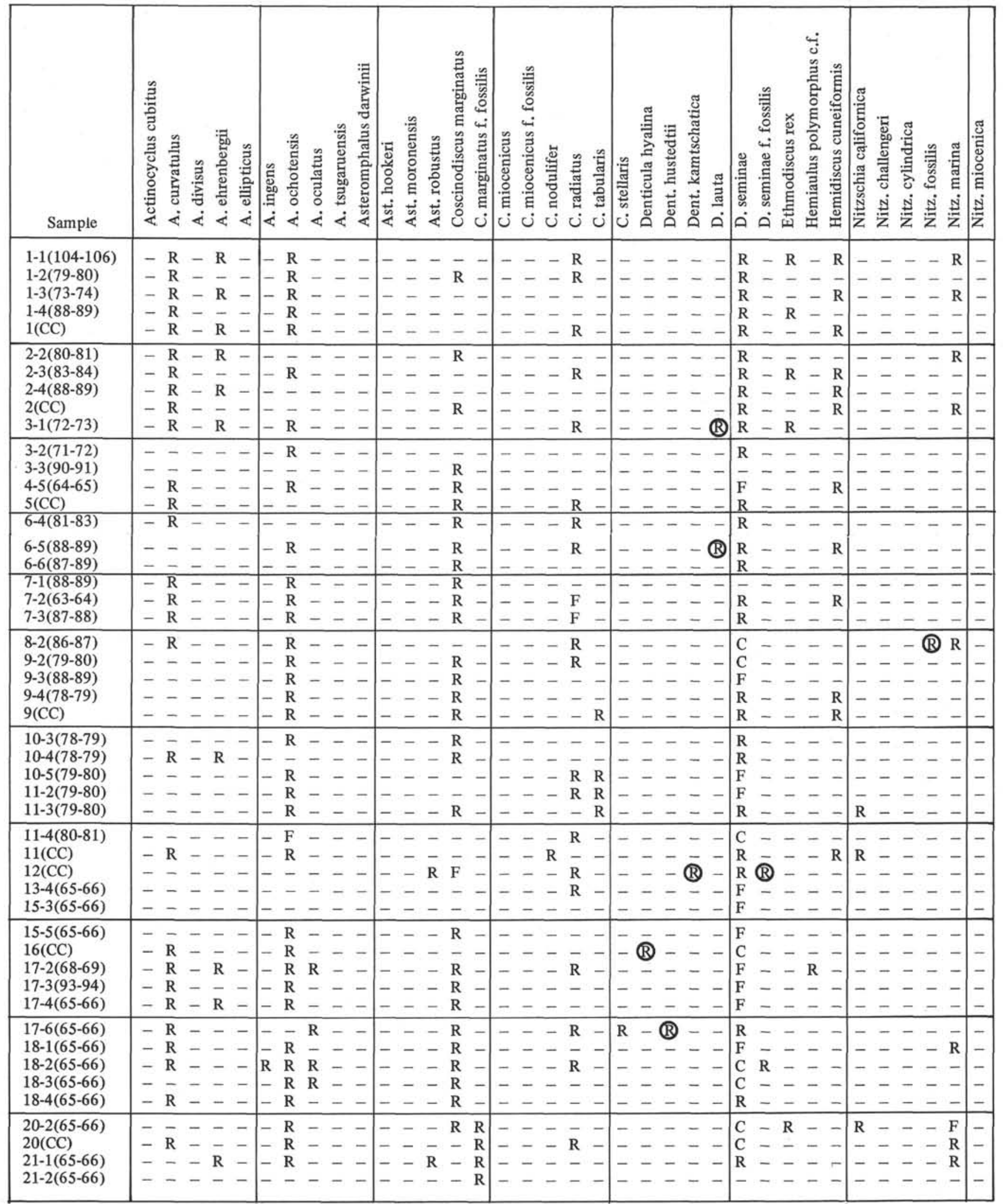


TABLE 2 - Continued

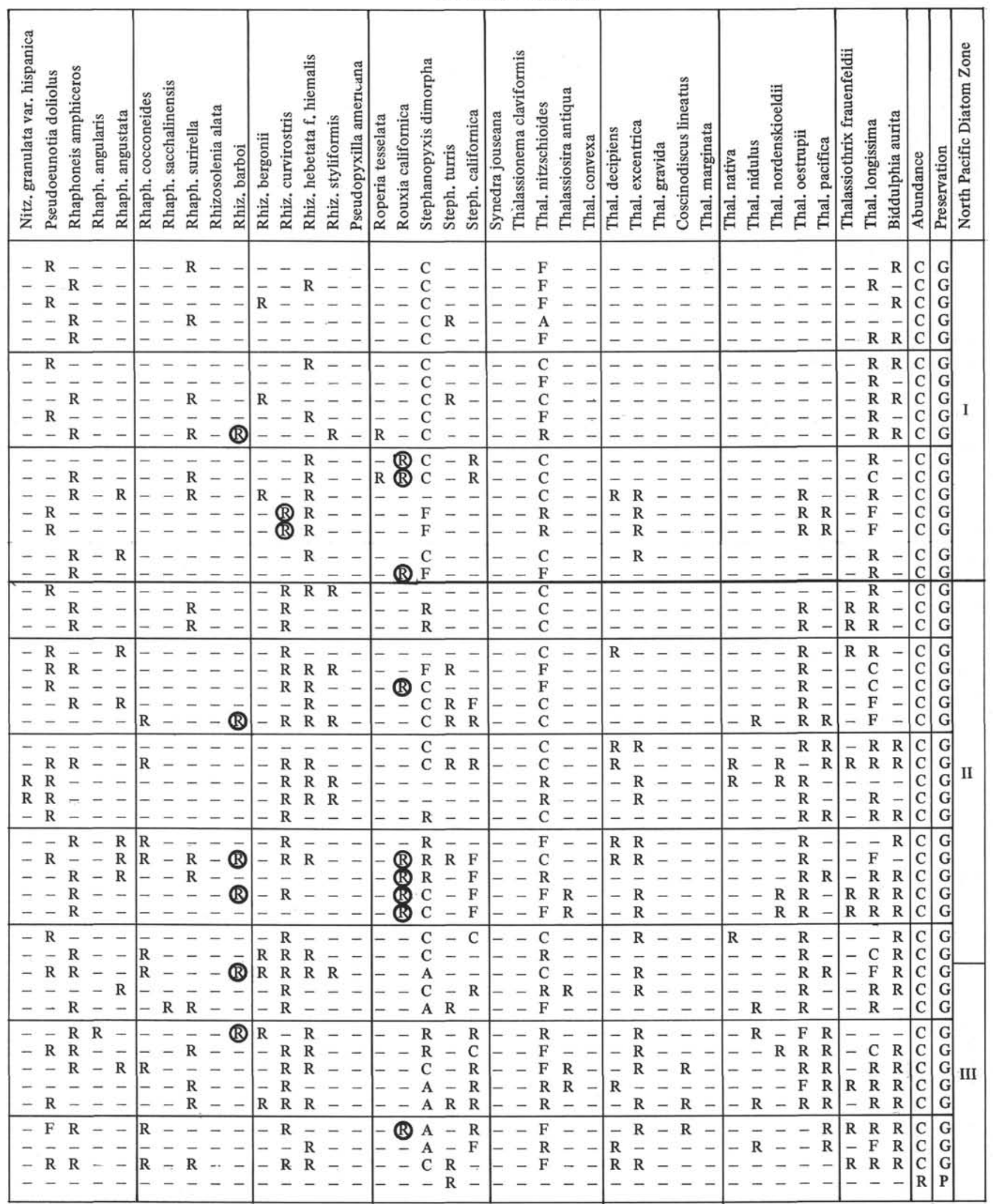




\section{Site 177 (Hole 177 and 177A)}

A sequence of alternating sandy muds, silts, and sandstones representing a series of fan deposits were encountered at Site 177. Diatoms were abundant to rare in the pelagic to hemipelagic sediments from 0 to 150 meters below the sea floor $(177-1-1,47-48 \mathrm{~cm}$ to $177 \mathrm{~A}-12-1-1$, $118-120 \mathrm{~cm})$. The section from 150 to 459.5 meters below the sea floor (177 A-12-2, 63-65 cm to $177 \mathrm{~A}-26, \mathrm{CC})$ was barren of diatoms (for more details see Figure 18 and Table $3)$. Preservation of frustules was moderate to good in the diatom-bearing muds. Species diversity was high in samples representing temperate to warm biofacies, and low in samples representing cool biofacies (see "Paleoclimatic Interpretation," this report). A few recrystallized diatom frustules were encountered in $177 \mathrm{~A}-14$ (CC). The abundance of older reworked fossils was high in the middle part of the section (177A-6-5, 64-66 cm to 177A-8-2, 65-67 $\mathrm{cm}$ ). The abundance of displaced (littoral marine, freshwater benthic and planktonic species) is negligible throughout the hole.

Detailed lists of diatom taxa identified in the samples are given in Table 3. The base of NPD Zone $I$ is at 27 meters (177A-2-6, 107-108 cm), the base of NPD Zone II at 47.6 meters (177A-5-2, 64-66 cm), the base of NPD Zones III and IV at 60.5 meters (177 A-6-5, 64-66 cm), and the base of NPD Zone V at 61.5 meters $(177 \mathrm{~A}-7-1,63-66 \mathrm{~cm})$; the base of NPD Zone VI has not been defined. The oldest recovered diatom-bearing sediment (177A-12-1, 118-120 $\mathrm{cm}$ ) falls within NPD Zone VI. No breaks in the diatom stratigraphic record were detected from 0 to 146 meters below the sea floor. NPD Zones III and IV could not be subdivided because of the lack of indicator species. Neither Denticula kamtschatica nor Thalassiosira convexa was encountered, indicating a Middle to Lower Pliocene age.

Based upon the placement of the base of NPD Zone I at 27 meters, of NPD Zone II at 47.6 meters, of NPD Zones III and IV at 60.5 meters, and of NPD Zone V at 61.5 meters, a sedimentation rate of 40 meters $/ \mathrm{m} . \mathrm{y}$. can be calculated (see Figure 36). The Pleistocene-Pliocene boundary falls within Core $6(177 \mathrm{~A}-6-5,64-66 \mathrm{~cm})$.

\section{Site 178}

Diatoms were found throughout Site 178 in the pelagic sediment-bearing intervals with varying abundance and preservation. Species diversity was high in warm intervals, low in cold intervals. The sequence from 0 to 740 meters below the sea floor represents a continuous record of high diatom productivity from Holocene to Upper Miocene with intermittent influx of sands, silts and mud turbidites. Several warmer periods were found in the Pleistocene to Upper Miocene section (see "Paleoclimatic Interpretation," this report). Reworking of older microfossils is negligible. Detailed lists of the planktonic diatom content of samples are given in Table 4.

The base of NPD Zone I is at 46 meters (178-6-3, 130-132 cm); of NPD Zone II, 125 meters (178-15-2, 36-38 $\mathrm{cm})$; of NPD Zones III and IV, 152 meters (178-18-2, 45-47 $\mathrm{cm}$ ); and of NPD Zones V and VI, 243 meters (178-28-4, $5-7 \mathrm{~cm})$. The base of NPD Zone VII is tentatively placed at 360 meters $(178-37-4,133-135 \mathrm{~cm})$ on the basis of the last occurrence of Thalassiosira convexa, the first occurrence of
Thalassiosira antiqua, and the first occurrence of Thalassiosira oestrupii; the base of NPD Zone VIII at 465 meters $(178-44-6,121-123 \mathrm{~cm})$ on the basis of the last occurrences of Denticula hustedtii and Denticula hyalina, the occurrences of Rouxia californica and Thalassiosira nativa, and the first occurrence of Denticula kamtschatica; and the base of NPD Zones IX and X at 690.5 meters (178-52, CC). The base of NPD Zone XIV was not detected. The oldest recovered diatom-bearing sediment, at 746 meters (178-54-3, 126-127 cm), is of Upper Miocene age.

Recovered thanatocoenoses belong to the recurrent group II representing the Subarctic Diatom Assemblage of Kanaya and Koizumi (1966).

Within the interval from 289 to 746 meters below the sea floor $(178-30-2,62-64 \mathrm{~cm}$ to $178-54-3,126-127 \mathrm{~cm})$, the preservation of diatom frustules was generally poor. The assemblage has been strongly dissolved and only the more robust tests have been preserved. Within this interval, Coscinodiscus marginatus, Coscinodiscus marginatus forma fossilis, and Coscinodiscus symbolophorus occur in masses whereas weekly silicified diatoms such as species of Denticula, Thalassiosira, and Nitzschia have been dissolved. Only in relict sediment in burrows could a few stratigraphic markers be detected and used for correlation. The NPD zone boundaries in the interval from 289 to 746 meters below the sea floor are tentative because most of the marker species have been removed from the assemblage by dissolution of opaline silica.

Based on the radiometric-paleomagnetic stratigraphy of the NPD zones, a sedimentation rate of $125 \mathrm{~m} / \mathrm{m}$.y. was obtained for the Pleistocene-Upper Pliocene interval (Figure 36).

\section{Site 179}

Diatoms are abundant to common in the pelagic to hemipelagic sequences at Site 179. They are well preserved in the interval from 0 to 92 meters below the sea floor and only a very few badly corroded to well-preserved displaced frustules were found below that level $(179-10$, CC to $179-13, \mathrm{CC})$. The sequence from 0 to 92 meters represents a continuous record of high diatom productivity from today to Upper Pliocene with intermittent influx of turbidity sequences. Several warmer periods occur within the generally cold biofacies (see "Paleoclimatic Interpretation," this report). The abundance of older reworked microfossils is generally low, but within the Upper Pleistocene NPD Zone I (179-2-2, 120-122 cm to 179-2-3, $147-149 \mathrm{~cm}$ ), a pure Lower Pliocene pelagic sequence was recovered. Detailed lists of planktonic diatom taxa in the samples are given in Table 5 .

The base of NPD Zone I is at 13.3 meters (179-3-1, 30-32 cm); of NPD Zone II, 43.5 meters (179-6-2, 120-122 $\mathrm{cm})$; of NPD Zone III, 53 meters (179-7-2, 65-67 cm); of NPD Zone IV, 63 meters (179-8-2, 90-92 cm); and of NPD Zone V, 72.5 meters $(179-9-2,110-112 \mathrm{~cm})$. The base of NPD Zone VI was not recognized. The oldest recovered diatom-bearing sediment $(179-10, \mathrm{CC})$ belongs to NPD Zone VI and is of Upper Pliocene age (younger than 2.2 m.y.).

No breaks in the diatom stratigraphic record were detected from 0 to 92 meters. Species diversity was 
TABLE 3

Diatoms at Site 177

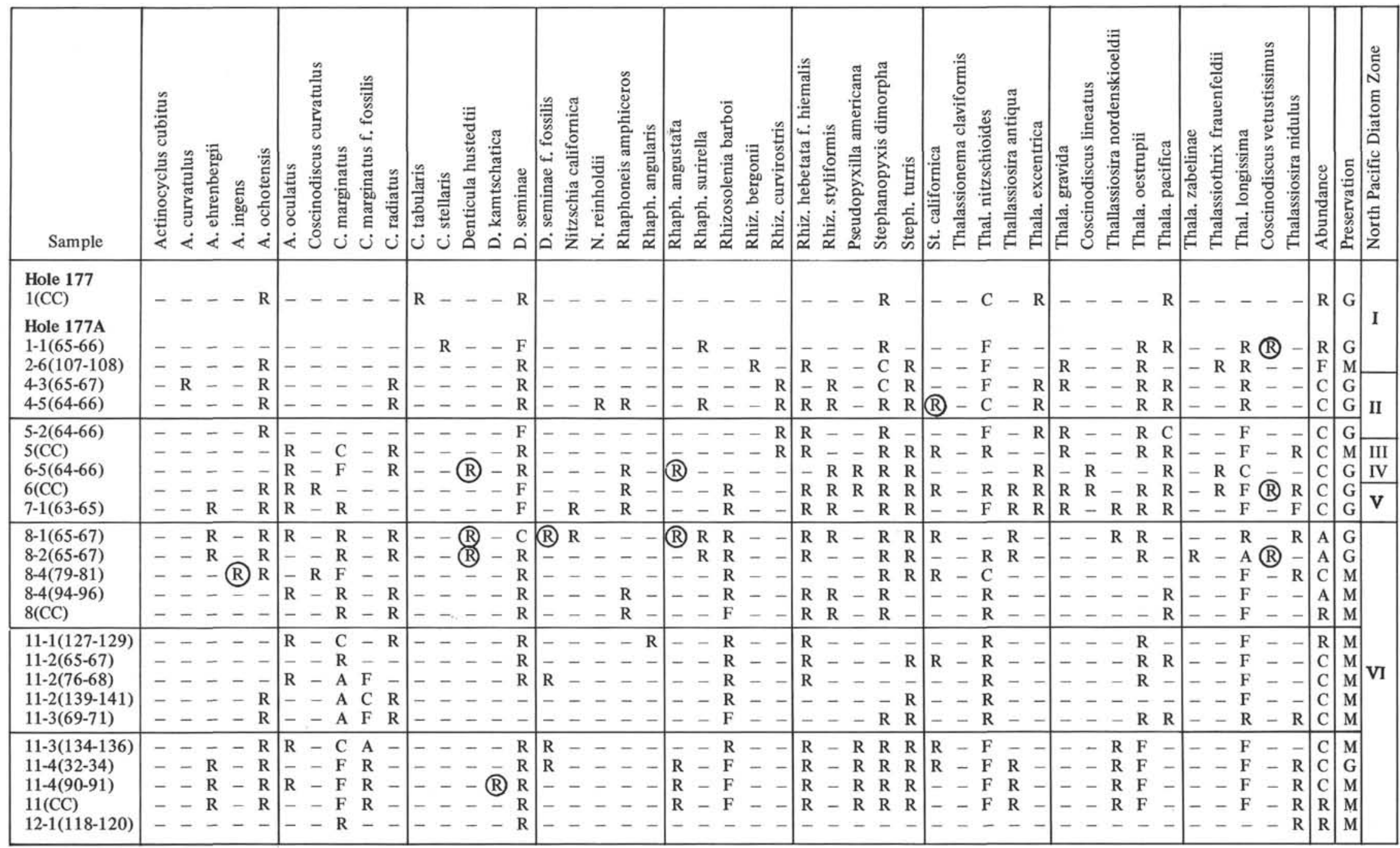


TABLE 4

Diatoms at Site 178

\begin{tabular}{|c|c|c|c|c|c|c|c|c|c|c|c|c|}
\hline Sample & 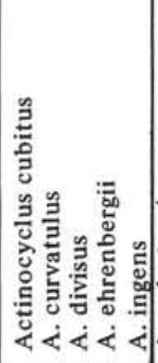 & 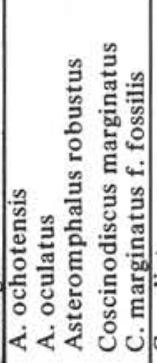 & 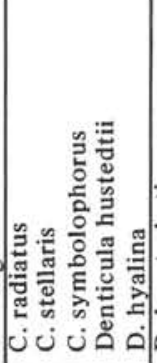 & 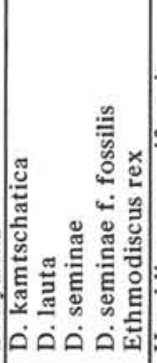 & 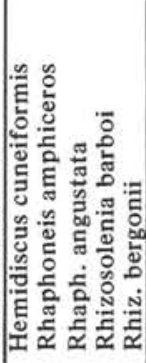 & 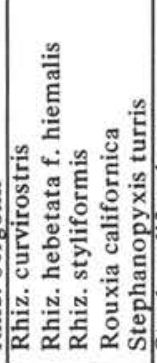 & 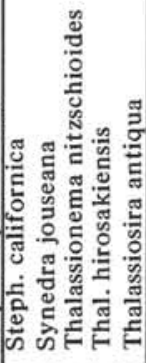 & 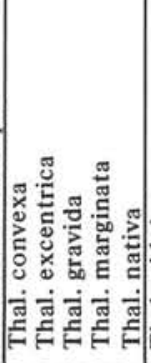 & 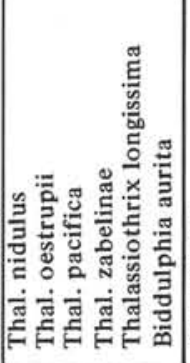 & 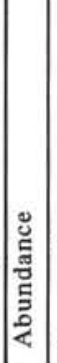 & 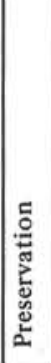 & 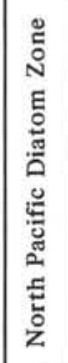 \\
\hline $\begin{array}{l}2-1(55-57) \\
2-1(120-122) \\
2(C C) \\
3-1(119-121) \\
3-3(120-122) \\
\end{array}$ & $\begin{array}{l}-\mathrm{C} C-- \\
-\mathrm{C} C-- \\
--\mathrm{F}-- \\
-\mathrm{R} \mathrm{R}-- \\
-\mathrm{R} \mathrm{R}--\end{array}$ & $\mid \begin{array}{l}\mathrm{R}---- \\
\mathrm{R}--\overline{\mathrm{F}} \\
\mathrm{R}--\mathrm{R} \\
\mathrm{R}--\mathrm{R}- \\
\mathrm{R}--\mathrm{R}-\end{array}$ & $\mid \begin{array}{l}-\mathrm{R}--- \\
-\mathrm{R}--- \\
\mathrm{R}---- \\
\mathrm{R}-----\end{array}$ & $\mid \begin{array}{l}--\mathrm{A}-- \\
--\mathrm{A}-- \\
--\mathrm{C}-- \\
--\mathrm{A}-- \\
--\mathrm{A}--\end{array}$ & $\begin{array}{l}----- \\
----- \\
----- \\
----- \\
-----\end{array}$ & $\left|\begin{array}{l}-R--R \\
-R--R \\
-R--- \\
-R--- \\
-F--R\end{array}\right|$ & $\begin{array}{l}----- \\
----- \\
----- \\
----- \\
----- \\
\end{array}$ & $\begin{array}{l}-\mathrm{R} R-- \\
--\mathrm{R}-- \\
-\mathrm{R} \mathrm{R}-- \\
-\overline{-}--- \\
-\mathrm{R} \mathrm{R}--\end{array}$ & $\begin{array}{l}-- \text { C }- \text { A R } \\
-- \text { C }- \text { A R } \\
-- \text { C }- \text { A }- \\
-- \text { F }- \text { C }- \\
-- \text { R }- \text { C R }\end{array}$ & $\begin{array}{l}\mathrm{A} \\
\mathrm{A} \\
\mathrm{C} \\
\mathrm{C} \\
\mathrm{C}\end{array}$ & $\begin{array}{l}G \\
G \\
G \\
G \\
G\end{array}$ & I \\
\hline $\begin{array}{l}4-3(120-122) \\
5-4(120-122) \\
6-3(130-132) \\
6-4(120-122) \\
8-4(120-122) \\
\end{array}$ & $\begin{array}{l}- \text { R R - } \\
- \text { R R - - } \\
- \text { F R - - } \\
- \text { R R - - } \\
- \text { R R - - } \\
\end{array}$ & $\begin{array}{l}\mathrm{R}--\mathrm{R}- \\
\mathrm{R}--\mathrm{R}- \\
\mathrm{R}--\mathrm{R}- \\
----- \\
-----\end{array}$ & $\mid \begin{array}{l}\mathrm{R}-\cdots-- \\
\mathrm{R}---- \\
\mathrm{R}-\cdots-- \\
----- \\
-----\end{array}$ & \begin{tabular}{|l|}
$--\mathrm{A}--$ \\
$--\mathrm{A}--$ \\
$--\mathrm{A}--$ \\
$--\mathrm{R}--$ \\
$--\mathrm{C}--$ \\
\end{tabular} & $\begin{array}{l}----- \\
----- \\
----- \\
----- \\
-----\end{array}$ & $\begin{array}{l}-F--R \\
-F--R \\
R R--R \\
R R---- \\
------\end{array}$ & $\begin{array}{l}----- \\
----- \\
----- \\
----- \\
----- \\
\end{array}$ & $\begin{array}{l}-\mathrm{R} R-- \\
-\mathrm{R} R-- \\
--\mathrm{R}-- \\
-\mathrm{R} C-- \\
----- \\
\end{array}$ & $\begin{array}{l}--\mathrm{R}-\mathrm{C} \mathrm{R} \\
-\mathrm{R} \mathrm{R}-\mathrm{C} \mathrm{R} \\
--\mathrm{A}-\mathrm{A}- \\
----\mathrm{R}- \\
--\mathrm{R}-\mathrm{A}-\end{array}$ & \begin{tabular}{|l|}
$\mathrm{C}$ \\
$\mathrm{C}$ \\
$\mathrm{A}$ \\
$\mathrm{C}$ \\
$\mathrm{C}$ \\
\end{tabular} & $\begin{array}{l}G \\
G \\
G \\
G \\
G\end{array}$ & \\
\hline $\begin{array}{l}9-3(100-102) \\
9-3(120-122) \\
10-1(120-122) \\
10-2(45-47) \\
11(\mathrm{CC}) \\
\end{array}$ & $\begin{array}{l}-F C-- \\
- \text { C F }-- \\
-\mathrm{R}--- \\
-\mathrm{C}--- \\
-\mathrm{F} C-- \\
\end{array}$ & $\begin{array}{l}---R- \\
F-R F- \\
R--R- \\
R--R- \\
--R R-\end{array}$ & \begin{tabular}{|c|}
----- \\
----- \\
----- \\
----- \\
----- \\
\end{tabular} & \begin{tabular}{|l|}
$--\mathrm{C}--$ \\
$--\mathrm{C}--$ \\
$--\mathrm{A}--$ \\
$--\mathrm{A}--$ \\
$--\mathrm{C}--$ \\
\end{tabular} & $\begin{array}{l}----- \\
----- \\
----- \\
----- \\
-----\end{array}$ & $\begin{array}{l}R \text { R }--R \\
R \text { F R }-- \\
-C \text { C - - } \\
\text { R C R - - } \\
\text { R C R }- \text { R }\end{array}$ & \begin{tabular}{|l}
---- \\
----- \\
----- \\
----- \\
----- \\
\end{tabular} & $\begin{array}{l}-\mathrm{R}--- \\
--\mathrm{R}-- \\
-\mathrm{R} R-- \\
-\mathrm{R} R-- \\
-\mathrm{R} R-- \\
\end{array}$ & $\begin{array}{l}----\mathrm{A}- \\
----\mathrm{A}- \\
--\mathrm{R}-\mathrm{A}- \\
----\mathrm{A}- \\
----\mathrm{C}-\end{array}$ & \begin{tabular}{l|}
$\mathrm{A}$ \\
$\mathrm{A}$ \\
$\mathrm{A}$ \\
$\mathrm{A}$ \\
$\mathrm{A}$
\end{tabular} & $\begin{array}{l}G \\
G \\
G \\
G \\
G\end{array}$ & II \\
\hline $\begin{array}{l}12-1(112-114) \\
12-2(41-43) \\
12-3(112-114) \\
13-1(113-115) \\
15-2(36-38)\end{array}$ & $\begin{array}{l}-\mathrm{C}--- \\
----- \\
-\mathrm{R}--- \\
-\mathrm{C} \mathrm{R}-- \\
-\mathrm{R}---\end{array}$ & $\begin{array}{l}\mathrm{R}-\mathrm{R} \mathrm{R}- \\
\mathrm{R}-\mathrm{R}- \\
\mathrm{R}-\mathrm{R} \mathrm{R}- \\
\mathrm{R} \mathrm{R}---\end{array}$ & \begin{tabular}{|c|}
----- \\
----- \\
----- \\
----- \\
----- \\
\end{tabular} & \begin{tabular}{|l|}
$--\mathrm{A}--$ \\
$--\mathrm{A}--$ \\
$--\mathrm{C}--$ \\
$--\mathrm{R}--$ \\
$--\mathrm{A}--$ \\
\end{tabular} & $\begin{array}{l}----- \\
----- \\
----- \\
----- \\
-----\end{array}$ & $\begin{array}{l}R \text { R R }-R \\
R-R-R \\
--R-R \\
R---- \\
C---R\end{array}$ & $\begin{array}{l}----- \\
----- \\
----- \\
----- \\
----- \\
\end{array}$ & \begin{tabular}{|l|}
$-\mathrm{R} R--$ \\
$-\mathrm{R} R--$ \\
$-\mathrm{R}---$ \\
$--\mathrm{R}--$ \\
$-\mathrm{R} \mathrm{R}--$ \\
\end{tabular} & $\begin{array}{l}-\mathrm{R} R-\mathrm{A}- \\
-\mathrm{R}--\mathrm{R}- \\
----\mathrm{C}- \\
-\mathrm{R} \mathrm{R}-\mathrm{A}- \\
----\mathrm{R}-\end{array}$ & \begin{tabular}{|l|}
$\mathrm{A}$ \\
$\mathrm{A}$ \\
$\mathrm{C}$ \\
$\mathrm{A}$ \\
$\mathrm{A}$
\end{tabular} & $\begin{array}{l}\mathrm{G} \\
\mathrm{G} \\
\mathrm{G} \\
\mathrm{G} \\
\mathrm{G}\end{array}$ & \\
\hline $\begin{array}{l}15-2(95-97) \\
16-1(138-140) \\
16-2(41-43) \\
16-2(113-115) \\
16-3(6-8)\end{array}$ & $\begin{array}{l}- \text { R R - } \\
- \text { R R - - } \\
- \text { R R - - } \\
- \text { R - - - } \\
- \text { A - - - }\end{array}$ & $\begin{array}{l}\mathrm{R}-\mathrm{R}-- \\
\mathrm{R} \mathrm{R} \mathrm{R}-\mathrm{-} \\
\mathrm{R} \mathrm{C}-\mathrm{R}- \\
-\mathrm{C}-\mathrm{R}- \\
--\mathrm{R} \mathrm{R}-\end{array}$ & $\mid \begin{array}{l}----- \\
\mathrm{R}---- \\
----- \\
---- \\
\mathrm{R}----\end{array}$ & $\begin{array}{l}--\mathrm{A}-- \\
--\mathrm{A}-- \\
--\mathrm{C}-- \\
--\mathrm{C}-- \\
--\mathrm{R}--\end{array}$ & $\begin{array}{l}----- \\
----- \\
----- \\
----- \\
-----\end{array}$ & $\begin{array}{l}R-R-R \\
R---R \\
----- \\
R--- \\
-R---\end{array}$ & $\begin{array}{l}----- \\
----- \\
----- \\
----- \\
--\mathrm{R}--\end{array}$ & $\begin{array}{l}-\mathrm{R} R-- \\
-\mathrm{R}--- \\
-\mathrm{R} \mathrm{R}-- \\
-\mathrm{R}--- \\
-\mathrm{R} \mathrm{R}--\end{array}$ & $\begin{array}{l}----\mathrm{C}- \\
----\mathrm{C}- \\
--\mathrm{R}-\mathrm{C}- \\
-\mathrm{R}-\mathrm{R}- \\
-\mathrm{R} \mathrm{R}-\mathrm{A}-\end{array}$ & \begin{tabular}{l|}
$\mathrm{A}$ \\
$\mathrm{A}$ \\
$\mathrm{A}$ \\
$\mathrm{C}$ \\
$\mathrm{A}$
\end{tabular} & \begin{tabular}{|l|} 
G \\
G \\
G \\
G \\
G \\
\end{tabular} & III \\
\hline $\begin{array}{l}16-3(121-123) \\
18-2(45-47) \\
19-2(44-46) \\
20-2(110-112) \\
23-3(50-52) \\
\end{array}$ & $\begin{array}{l}----- \\
----- \\
-\overline{-}--- \\
-\mathrm{F}--- \\
-\mathrm{R}---\end{array}$ & $\begin{array}{l}- \text { C R }-- \\
- \text { F R R - } \\
- \text { R C - - } \\
- \text { R C - - } \\
\text { R R C R - }\end{array}$ & $\begin{array}{c}----- \\
----- \\
----- \\
----- \\
-----\end{array}$ & $\begin{array}{l}--\mathrm{A}-- \\
--\mathrm{C}-- \\
--\mathrm{R}-- \\
--\mathrm{R}-- \\
--\mathrm{R}--\end{array}$ & $\begin{array}{l}---- \\
---\mathrm{R}- \\
---\mathrm{F}- \\
---\mathrm{F}- \\
---\mathrm{A}-\end{array}$ & $\mid \begin{array}{c}\mathrm{R}---\mathrm{R} \\
\mathrm{R}---- \\
----- \\
----- \\
--\mathrm{R}--\end{array}$ & $\begin{array}{l}----- \\
----- \\
----R \\
-\cdots-R \\
----R\end{array}$ & $\begin{array}{l}-\mathrm{R} R-- \\
-\mathrm{R} R-- \\
--\mathrm{R}-- \\
--\mathrm{R}-- \\
-----\end{array}$ & $\begin{array}{l}----C- \\
R-R-C- \\
----C- \\
----C- \\
R-R R C-\end{array}$ & $\begin{array}{l}\mathrm{A} \\
\mathrm{A} \\
\mathrm{C} \\
\mathrm{A} \\
\mathrm{A}\end{array}$ & $\begin{array}{l}\text { G } \\
\text { G } \\
\text { G } \\
\text { G } \\
\text { G }\end{array}$ & $\begin{array}{l}\text { V } \\
+ \\
\text { VI }\end{array}$ \\
\hline $\begin{array}{l}26-3(96-98) \\
28-4(5-7) \\
30-2(62-64) \\
31-2(10-12) \\
31-2(115-117)\end{array}$ & \begin{tabular}{|l|}
----- \\
----- \\
----- \\
----- \\
----- \\
\end{tabular} & $\begin{array}{l}-\mathrm{R}-\mathrm{A}- \\
\mathrm{R} \mathrm{R}-\mathrm{R}- \\
-\mathrm{R}-\mathrm{A}- \\
\mathrm{R}--\mathrm{A}- \\
\mathrm{R}--\mathrm{A}-\end{array}$ & \begin{tabular}{|c|}
----- \\
----- \\
----- \\
----- \\
----- \\
\end{tabular} & $\mid \begin{array}{l}---\bar{C} \\
R-C R- \\
R-R-- \\
----- \\
---\mathrm{R}-\end{array}$ & $\begin{array}{l}---\mathrm{R}- \\
---\mathrm{R}- \\
-\mathrm{R} \mathrm{R} \mathrm{R}- \\
----- \\
-----\end{array}$ & \begin{tabular}{|c|}
----- \\
----- \\
----- \\
$----\mathrm{R}$ \\
$----\mathrm{R}$
\end{tabular} & $\begin{array}{c}----\bar{R} \\
----\mathrm{R} \\
--\mathrm{R}-\mathrm{R} \\
----\mathrm{R} \\
----\mathrm{R}\end{array}$ & \begin{tabular}{|l|}
----- \\
----- \\
----- \\
----- \\
----- \\
\end{tabular} & $\begin{array}{l}----\mathrm{R}- \\
----\mathrm{C}- \\
----\mathrm{R}- \\
-\mathrm{R} R-\mathrm{C}- \\
-\mathrm{R} \mathrm{R}-\mathrm{C}-\end{array}$ & \begin{tabular}{|l|}
$\mathrm{C}$ \\
$\mathrm{C}$ \\
$\mathrm{C}$ \\
$\mathrm{C}$ \\
$\mathrm{A}$ \\
\end{tabular} & $\begin{array}{l}\mathrm{M} \\
\mathrm{G} \\
\mathrm{M} \\
\mathrm{P} \\
\mathrm{P}\end{array}$ & \\
\hline $\begin{array}{l}31(\mathrm{CC}) \\
32-1(30-32) \\
32-2(25-27) \\
32-3(41-43) \\
32-3(130-132) \\
\end{array}$ & $\begin{array}{l}----- \\
----- \\
----- \\
----\mathrm{R} \\
----- \\
\end{array}$ & \begin{tabular}{|l|}
$---\mathrm{A}-$ \\
$---\mathrm{A}-$ \\
$---\mathrm{A}-$ \\
$---\mathrm{A}-$ \\
$---\mathrm{A}-$ \\
\end{tabular} & \begin{tabular}{|c|}
----- \\
----- \\
----- \\
----- \\
----- \\
\end{tabular} & \begin{tabular}{|l|}
$--\mathrm{R}--$ \\
$--\overline{\mathrm{R}}$ \\
$--\mathrm{R}-$ \\
----- \\
$\mathrm{R}----$
\end{tabular} & $\begin{array}{l}----- \\
---\mathrm{R}- \\
----- \\
-\mathrm{R}-\mathrm{R}- \\
\mathrm{R}----\end{array}$ & \begin{tabular}{|c|}
----- \\
----- \\
----- \\
----- \\
----- \\
\end{tabular} & \begin{tabular}{|l}
---- \\
----- \\
----- \\
----- \\
$--\mathrm{R}--$
\end{tabular} & \begin{tabular}{|l|}
----- \\
----- \\
----- \\
----- \\
----- \\
\end{tabular} & $\begin{array}{l}----\mathrm{C}- \\
----\mathrm{R}- \\
----\mathrm{R}- \\
----\mathrm{R}- \\
----\mathrm{C}-\end{array}$ & \begin{tabular}{l|}
$\mathrm{C}$ \\
$\mathrm{A}$ \\
$\mathrm{C}$ \\
$\mathrm{C}$ \\
$\mathrm{A}$
\end{tabular} & $\begin{array}{l}\mathrm{P} \\
\mathrm{P} \\
\mathrm{P} \\
\mathrm{M}\end{array}$ & \\
\hline $\begin{array}{l}32(C C) \\
33-4(116-118) \\
33-5(52-54) \\
33(C C) \\
34-2(45-47) \\
34-4(29-31) \\
\end{array}$ & $\begin{array}{l}----- \\
----- \\
----- \\
----- \\
----- \\
-----\end{array}$ & $\begin{array}{l}---\mathrm{A}- \\
---\mathrm{C}- \\
---\mathrm{A}- \\
---\mathrm{A}- \\
---\mathrm{A}- \\
--\mathrm{RA}-\end{array}$ & $\mid \begin{array}{c}----- \\
----- \\
----- \\
----- \\
----- \\
-----\end{array}$ & $\left|\begin{array}{l}\mathrm{R}---- \\
----- \\
----- \\
----- \\
---- \\
\mathrm{R}----\end{array}\right|$ & $\begin{array}{l}\mathrm{R}--\mathrm{R}- \\
----- \\
----- \\
----- \\
----- \\
---\mathrm{R}-\end{array}$ & $\mid \begin{array}{c}----- \\
----- \\
----- \\
----- \\
----- \\
----- \\
-\end{array}$ & $\begin{array}{c}--\mathrm{R}-\mathrm{R} \\
----- \\
----- \\
----- \\
----- \\
----- \\
\end{array}$ & $\begin{array}{l}----- \\
----- \\
----- \\
----- \\
----- \\
----- \\
\end{array}$ & $\begin{array}{l}-\mathrm{R}--\mathrm{C}- \\
----\mathrm{R}- \\
----\mathrm{R}- \\
----\overline{\mathrm{R}}- \\
----\mathrm{R}- \\
-\mathrm{R}--\mathrm{C}-\end{array}$ & $\begin{array}{l}\mathrm{A} \\
\mathrm{R} \\
\mathrm{R} \\
\mathrm{R} \\
\mathrm{C} \\
\mathrm{A} \\
\end{array}$ & $\begin{array}{l}\mathrm{M} \\
\mathrm{M} \\
\mathrm{M} \\
\mathrm{P} \\
\mathrm{P} \\
\mathrm{M}\end{array}$ & VII \\
\hline $\begin{array}{l}34-6(121-123) \\
35-2(86-88) \\
35(C C) \\
36-1(123-125) \\
37-1(45-47) \\
\end{array}$ & $\begin{array}{l}----- \\
----- \\
----- \\
----- \\
----- \\
\end{array}$ & \begin{tabular}{|c|}
$--\mathrm{R} A-$ \\
$---\mathrm{A}-$ \\
$---\mathrm{C}-$ \\
$---\mathrm{R}-$ \\
$---\mathrm{A}-$ \\
\end{tabular} & $\mid \begin{array}{c}----- \\
----- \\
----- \\
----- \\
-----\end{array}$ & $\begin{array}{l}----- \\
\mathrm{R}---- \\
\mathrm{R}---- \\
\mathrm{R}---- \\
\mathrm{R}----\end{array}$ & $\begin{array}{l}---\mathrm{R}- \\
----- \\
-\mathrm{R} \mathrm{R}-- \\
---\mathrm{R}- \\
---\mathrm{R}-\end{array}$ & \begin{tabular}{|c|}
----- \\
----- \\
----- \\
----- \\
----- \\
\end{tabular} & \begin{tabular}{|l}
---- \\
----- \\
$----\mathrm{R}$ \\
$----\mathrm{R}$ \\
-----
\end{tabular} & \begin{tabular}{|l|}
----- \\
----- \\
----- \\
----- \\
$-\mathrm{R}----$ \\
\end{tabular} & $\begin{array}{l}----\mathrm{C}- \\
----\mathrm{C}- \\
\mathrm{R}--\mathrm{R} C- \\
----\mathrm{C}- \\
-\mathrm{R}-\mathrm{R}--\end{array}$ & \begin{tabular}{|l|}
$\mathrm{A}$ \\
$\mathrm{A}$ \\
$\mathrm{C}$ \\
$\mathrm{C}$ \\
$\mathrm{A}$ \\
\end{tabular} & $\begin{array}{l}\mathrm{M} \\
\mathrm{M} \\
\mathrm{M} \\
\mathrm{M} \\
\mathrm{M}\end{array}$ & \\
\hline
\end{tabular}


TABLE 4 - Continued

\begin{tabular}{|c|c|c|c|c|c|c|c|c|c|c|c|c|}
\hline Sample & 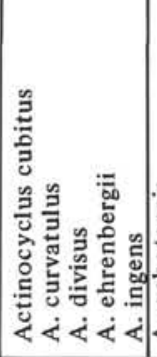 & 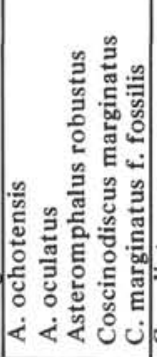 & 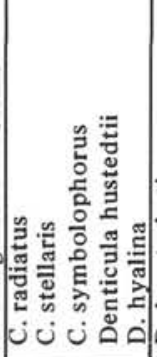 & 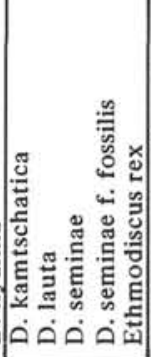 & 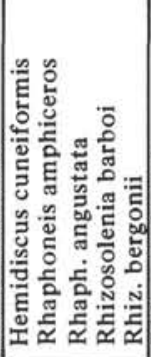 & 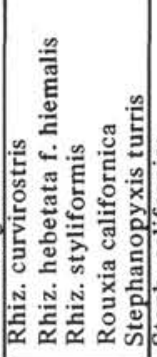 & 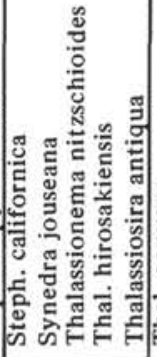 & 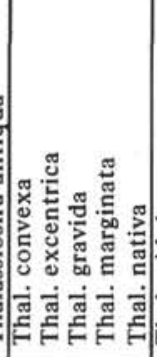 & 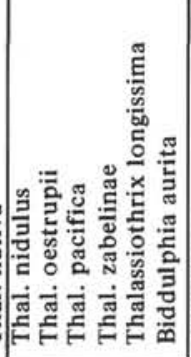 & 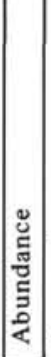 & 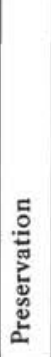 & 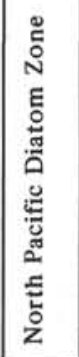 \\
\hline $\begin{array}{l}37-2(39-41) \\
37-3(44-46) \\
37-3(127-129) \\
37-4(78-80) \\
37-4(133-135) \\
\end{array}$ & $\begin{array}{l}----f \\
----- \\
----- \\
----- \\
-----\end{array}$ & $\begin{array}{c}---\mathrm{A}- \\
---\mathrm{A}- \\
---\mathrm{A}- \\
---\mathrm{A}- \\
---\mathrm{A}-\end{array}$ & $\mid \begin{array}{c}----- \\
----- \\
--\mathrm{R}-- \\
----- \\
-----\end{array}$ & $\begin{array}{l}\mathrm{R}---- \\
\mathrm{R}---- \\
\mathrm{R}--- \\
\mathrm{A}---- \\
\mathrm{R}---\mathrm{R}\end{array}$ & \begin{tabular}{|l|}
$--\mathrm{R}-$ \\
$-\mathrm{R}-\mathrm{R}-$ \\
$\mathrm{R}$ R R R - \\
$---\mathrm{R}-$ \\
$-\mathrm{R}-\mathrm{R}-$ \\
\end{tabular} & \begin{tabular}{|l|}
$-\mathrm{R}----$ \\
$-\mathrm{R}---$ \\
----- \\
----- \\
$-\mathrm{R}--\mathrm{R}$
\end{tabular} & {$\left[\begin{array}{c}--- \text { F R } \\
--- \text { C R } \\
- \text { R R C C } \\
--- \text { R } \\
--- \text { C R } \\
\end{array}\right.$} & \begin{tabular}{|l|}
$-\mathrm{R}---$ \\
$-\mathrm{R}---$ \\
$-\mathrm{R}-\mathrm{R}-$ \\
$-\mathrm{R}---$
\end{tabular} & $\begin{array}{l}-\mathrm{R}--\mathrm{R}- \\
-\mathrm{R}--\mathrm{C}- \\
-\mathrm{R}--\mathrm{C}- \\
-\mathrm{R}-\mathrm{R} \mathrm{C}- \\
----\mathrm{C}-\end{array}$ & \begin{tabular}{|l|}
$\mathrm{A}$ \\
$\mathrm{C}$ \\
$\mathrm{C}$ \\
$\mathrm{A}$ \\
$\mathrm{A}$ \\
\end{tabular} & $\begin{array}{l}\mathrm{M} \\
\mathrm{M} \\
\mathrm{M} \\
\mathrm{M} \\
\mathrm{M} \\
\end{array}$ & \\
\hline $\begin{array}{l}37(\mathrm{CC}) \\
38-1(65-67) \\
39-5(122-124) \\
39-6(70-72) \\
39-6(129-131) \\
40(\mathrm{CC})\end{array}$ & $\begin{array}{l}----- \\
----- \\
----- \\
---- \\
----- \\
-----\end{array}$ & $\begin{array}{c}---\mathrm{F}- \\
---\mathrm{A}- \\
---\mathrm{A}- \\
---\mathrm{A}- \\
---\mathrm{A}- \\
---\mathrm{A} \mathrm{R}\end{array}$ & $\mid \begin{array}{l}--\cdots-- \\
\mathrm{R}---- \\
----- \\
----- \\
----- \\
-----\end{array}$ & \begin{tabular}{|l|}
$\mathrm{F}----$ \\
$\mathrm{R}----$ \\
---- \\
--- \\
$\mathrm{F}-----$
\end{tabular} & \begin{tabular}{|l} 
R R R R - \\
$-\mathrm{R}-\mathrm{R}-$ \\
----- \\
----- \\
----- \\
$---\mathrm{R}-$
\end{tabular} & \begin{tabular}{|l|}
$--\mathrm{R}--$ \\
$-\mathrm{R} \mathrm{R}--$ \\
----- \\
----- \\
----- \\
------ \\
\end{tabular} & \begin{tabular}{|c|}
-- C R \\
--- F R \\
----- \\
---- \\
----- \\
---- \\
\end{tabular} & $\mid \begin{array}{l}\mathrm{R}---- \\
\mathrm{R}---- \\
----- \\
----- \\
----- \\
-----\end{array}$ & $\begin{array}{l}\mathrm{R} R--\mathrm{C}- \\
-\mathrm{R}--\mathrm{F}- \\
----\mathrm{R}- \\
----\mathrm{C}- \\
----\mathrm{R}- \\
----\mathrm{R}-\end{array}$ & \begin{tabular}{|l|}
$\mathrm{A}$ \\
$\mathrm{C}$ \\
$\mathrm{A}$ \\
$\mathrm{C}$ \\
$\mathrm{A}$ \\
$\mathrm{A}$
\end{tabular} & $\begin{array}{l}\mathrm{M} \\
\mathrm{P} \\
\mathrm{P} \\
\mathrm{P} \\
\mathrm{P} \\
\mathrm{P}\end{array}$ & \\
\hline $\begin{array}{l}43-3(131-133) \\
44-1(72-74) \\
44-2(16-18) \\
44-2(71-73) \\
44-3(58-60)\end{array}$ & $\begin{array}{l}-----1 \\
-----1 \\
----\mathrm{R} \\
-----1 \\
-----\end{array}$ & $\begin{array}{c}-- \text { A R } \\
--- \text { A R } \\
--- \text { A R } \\
--- \text { A R } \\
-- \text { A R }\end{array}$ & $\mid \begin{array}{l}-\cdots-- \\
-\cdots- \\
----- \\
R-\cdots- \\
-\cdots-\cdots\end{array}$ & $\mid \begin{array}{l}----- \\
----- \\
\mathrm{R}---- \\
---- \\
-----\end{array}$ & $\begin{array}{l}----- \\
----- \\
---\mathrm{R}- \\
----- \\
----- \\
\end{array}$ & $\mid \begin{array}{c}----- \\
----- \\
-\mathrm{R}--- \\
----- \\
-----\end{array}$ & $\mid \begin{array}{c}----- \\
----- \\
---\mathrm{R}- \\
---\mathrm{C}- \\
-----\end{array}$ & $\mid \begin{array}{l}----- \\
----- \\
----- \\
\mathrm{R}---- \\
---\cdots\end{array}$ & $\mid \begin{array}{l}----\mathrm{C}- \\
----\overline{\mathrm{F}}- \\
----\mathrm{C}- \\
----\mathrm{C} \\
------\end{array}$ & \begin{tabular}{|l|}
$\mathrm{A}$ \\
$\mathrm{C}$ \\
$\mathrm{A}$ \\
$\mathrm{A}$ \\
$\mathrm{A}$
\end{tabular} & $\begin{array}{l}\mathrm{P} \\
\mathrm{P} \\
\mathrm{P} \\
\mathrm{P} \\
\mathrm{P} \\
\end{array}$ & VIII \\
\hline $\begin{array}{l}44-5(81-83) \\
44-6(21 \mathrm{~cm}) \\
44-6(53-55) \\
44-6(121-123) \\
44(C C)\end{array}$ & $\begin{array}{l}----\mathrm{R} \\
----\mathrm{R} \\
----\mathrm{R} \\
----\bar{R} \\
----\mathrm{R} \\
\end{array}$ & \begin{tabular}{|l|}
--- A R \\
--- A C \\
--- A C \\
--- A F \\
--- A R
\end{tabular} & $\mid \begin{array}{l}\mathrm{R}-\cdots-- \\
----- \\
-\cdots-- \\
---\overline{\mathrm{R}} \\
---\mathrm{R}\end{array}$ & \begin{tabular}{|l|}
$\mathrm{R}---\mathrm{R}$ \\
--- \\
---- \\
$\mathrm{R}---$ \\
\end{tabular} & \begin{tabular}{|l|}
$-\mathrm{R}-\mathrm{R}-$ \\
$-\mathrm{R}-\mathrm{R}-$ \\
----- \\
----- \\
$---\mathrm{R}-$ \\
\end{tabular} & $\mid \begin{array}{c}----\frac{1}{2} \\
----\mathrm{R} \\
-\overline{\mathrm{R}}---- \\
--\mathrm{R}-\end{array}$ & $\mid \begin{array}{c}---\mathrm{R}- \\
---\overline{\mathrm{F}}- \\
---\mathrm{F}- \\
---\overline{\mathrm{C}}- \\
----\mathrm{C}\end{array}$ & $\mid \begin{array}{l}\mathrm{R}-\cdots-\mathrm{R} \\
\mathrm{R}----- \\
\mathrm{R}---- \\
\mathrm{R}----\end{array}$ & $\begin{array}{l}----\mathrm{C}- \\
----\mathrm{C}- \\
----\mathrm{C}- \\
----\mathrm{R}- \\
----\mathrm{C}-\end{array}$ & \begin{tabular}{|l|}
$\mathrm{A}$ \\
$\mathrm{A}$ \\
$\mathrm{A}$ \\
$\mathrm{A}$ \\
$\mathrm{A}$ \\
\end{tabular} & $\begin{array}{l}\mathrm{M} \\
\mathrm{M} \\
\mathrm{P} \\
\mathrm{M} \\
\mathrm{M} \\
\end{array}$ & - \\
\hline $\begin{array}{l}45-1-5(\mathrm{CM}) \\
45-1(32-34) \\
46-2(32-34) \\
50-1(35-37) \\
50-2(68-69)\end{array}$ & $\begin{array}{l}----\mathrm{R} \\
----- \\
----- \\
----- \\
----\mathrm{R}\end{array}$ & $\mid \begin{array}{l}--- \text { A A } \\
--- \text { A C } \\
--- \text { A R } \\
--- \text { A C } \\
--- \text { A C }\end{array}$ & $\begin{array}{l}----- \\
----- \\
--\bar{C} \\
--\mathrm{C}-- \\
--\mathrm{C}--\end{array}$ & $\begin{array}{l}----\bar{R} \\
----\mathrm{R} \\
----\frac{-}{2} \\
-----\mathrm{R} \\
----\mathrm{R}\end{array}$ & \begin{tabular}{|l|}
----- \\
----- \\
----- \\
----- \\
----- \\
\end{tabular} & $\left|\begin{array}{c}----- \\
----- \\
----- \\
----- \\
-----\end{array}\right|$ & $\mid \begin{array}{c}----- \\
---\mathrm{R}- \\
---\mathrm{R}- \\
---\mathrm{R}- \\
-----\end{array}$ & $\left|\begin{array}{l}\mathrm{R}---- \\
----- \\
----- \\
----- \\
-----\end{array}\right|$ & $\mid \begin{array}{l}----\mathrm{C}- \\
----\mathrm{R}- \\
----\mathrm{R}- \\
----\mathrm{R}- \\
----\mathrm{C}-\end{array}$ & $\begin{array}{l}\mathrm{A} \\
\mathrm{A} \\
\mathrm{C} \\
\mathrm{R} \\
\mathrm{C} \\
\end{array}$ & $\begin{array}{l}\mathrm{G} \\
\mathrm{M} \\
\mathrm{P} \\
\mathrm{P} \\
\mathrm{P} \\
\end{array}$ & IX \\
\hline $\begin{array}{l}50-3(18-19) \\
52-2(108-110) \\
52(C C) \\
54-1(146-147) \\
54-2(26-27) \\
\end{array}$ & \begin{tabular}{|l|}
----- \\
----- \\
$----\mathrm{R}$ \\
$----\mathrm{R}$ \\
$----\mathrm{R}$ \\
\end{tabular} & $\begin{array}{c}--- \text { A R } \\
--- \text { C C } \\
--- \text { C R } \\
--- \text { C C } \\
--- \text { C F }\end{array}$ & $\begin{array}{l}--C-- \\
--C-- \\
--R-R \\
-R C-- \\
--C--\end{array}$ & $\begin{array}{l}----\mathrm{R} \\
----- \\
-\overline{-}- \\
-\mathrm{R}--- \\
----- \\
\end{array}$ & \begin{tabular}{|l|}
$---\mathrm{R}-$ \\
----- \\
$-\mathrm{R}-\mathrm{R}-$ \\
----- \\
$---\mathrm{C}-$ \\
\end{tabular} & \begin{tabular}{|l|}
$-\mathrm{R}----$ \\
$-\mathrm{R}---$ \\
$-\mathrm{R}---$ \\
----- \\
-----
\end{tabular} & $\mid \begin{array}{c}----- \\
----- \\
---\mathrm{R}- \\
---\mathrm{R}- \\
----\end{array}$ & \begin{tabular}{|l|}
----- \\
----- \\
----- \\
----- \\
----- \\
\end{tabular} & $\begin{array}{l}----\mathrm{C}- \\
----\mathrm{C}- \\
----\mathrm{C}- \\
----\mathrm{R}- \\
----\mathrm{R}-\end{array}$ & \begin{tabular}{|l|}
$\mathrm{A}$ \\
$\mathrm{A}$ \\
$\mathrm{C}$ \\
$\mathrm{A}$ \\
$\mathrm{A}$
\end{tabular} & $\begin{array}{l}\mathrm{P} \\
\mathrm{P} \\
\mathrm{P} \\
\mathrm{P} \\
\mathrm{P}\end{array}$ & $\mathrm{X}$ \\
\hline $\begin{array}{l}54-3(36-37) \\
54-3(41-42) \\
54-3(126-127)\end{array}$ & $\begin{array}{l}----- \\
----- \\
----\mathrm{R} \\
\end{array}$ & \begin{tabular}{|l|}
--- C R \\
--- R R \\
--- C R
\end{tabular} & $\begin{array}{l}--\mathrm{C}-- \\
--\mathrm{C}- \\
--\mathrm{C}-\end{array}$ & \begin{tabular}{|l|}
----- \\
---- \\
----- \\
\end{tabular} & \begin{tabular}{|l|}
$---\mathrm{R}-$ \\
$---\overline{-}$ \\
$---\mathrm{F}-$ \\
\end{tabular} & \begin{tabular}{|l|}
----- \\
----- \\
----- \\
\end{tabular} & \begin{tabular}{|c|}
$--\mathrm{R}-$ \\
----- \\
----- \\
\end{tabular} & \begin{tabular}{|l|}
----- \\
----- \\
----- \\
\end{tabular} & $\begin{array}{l}----\mathrm{R}- \\
------ \\
------\end{array}$ & \begin{tabular}{|l|}
$\mathrm{C}$ \\
$\mathrm{R}$ \\
$\mathrm{R}$ \\
\end{tabular} & $\begin{array}{l}\mathrm{M} \\
\mathrm{M} \\
\mathrm{P}\end{array}$ & XVI \\
\hline
\end{tabular}


TABLE 5

Diatoms at Site 179

\begin{tabular}{|c|c|c|c|c|c|c|c|c|c|c|c|}
\hline Sample & 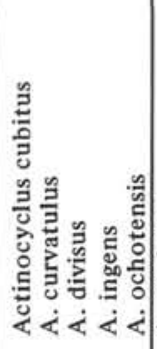 & 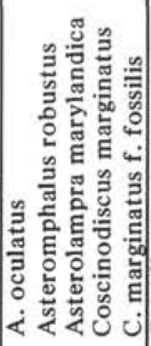 & \begin{tabular}{|l}
1 \\
\end{tabular} & 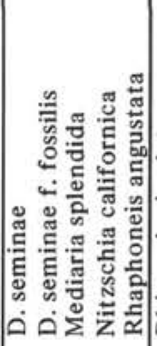 & 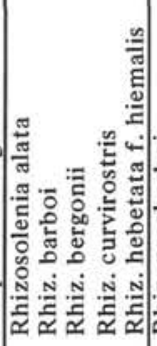 & 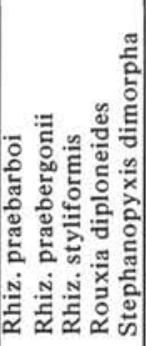 & 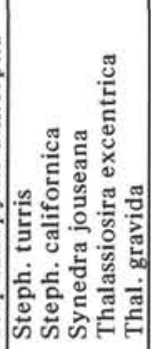 & 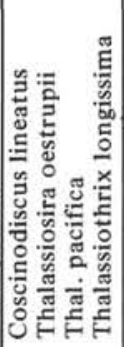 & 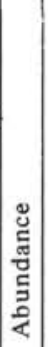 & 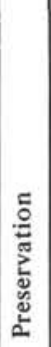 & 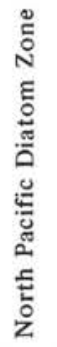 \\
\hline $\begin{array}{l}1-1(146-148) \\
1-2(44-46) \\
1-2(119-121) \\
1-3(45-47) \\
1-3(114-116)\end{array}$ & $\begin{array}{l}F-R-R \\
F-R-R \\
F-R-R \\
R-R-R \\
R-R-R\end{array}$ & $\mid \begin{array}{c}---\mathrm{F}- \\
---\mathrm{F}- \\
---\mathrm{F}- \\
--\mathrm{F}- \\
--\mathrm{R}-\end{array}$ & \begin{tabular}{|l|}
$-\mathrm{R} R--$ \\
$-\mathrm{R}---$ \\
$-\mathrm{R} \mathrm{R}--$ \\
$-\mathrm{R}---$ \\
-----
\end{tabular} & $\mid \begin{array}{l}\mathrm{C}---- \\
\mathrm{C}---- \\
\mathrm{C}---- \\
\mathrm{C}---- \\
\mathrm{C}----\end{array}$ & $\mid \begin{array}{c}----\mathrm{R} \\
----\mathrm{R} \\
----\mathrm{R} \\
----\mathrm{R} \\
----\mathrm{F}\end{array}$ & $\begin{array}{l}----- \\
----- \\
----- \\
----\mathrm{R} \\
-----\end{array}$ & $\mid \begin{array}{c}--\mathrm{R}- \\
---\mathrm{R}- \\
---\mathrm{R}- \\
----\mathrm{R} \\
---\mathrm{R}-\end{array}$ & $\begin{array}{l}-- \text { F C } \\
-- \text { F C } \\
-- \text { F C } \\
-- \text { F C } \\
-- \text { R F }\end{array}$ & $\begin{array}{l}\mathrm{R} \\
\mathrm{C} \\
\mathrm{A} \\
\mathrm{A} \\
\mathrm{R}\end{array}$ & $\begin{array}{l}M \\
G \\
G \\
G \\
G\end{array}$ & \multirow{3}{*}{ I } \\
\hline $\begin{array}{l}2-1(44-46) \\
2-1(118-120) \\
2-2(120-122) \\
2-3(147-149) \\
2-4(68-70)\end{array}$ & $\begin{array}{l}R-R-R \\
R---R \\
R-R-- \\
--R R- \\
---A-\end{array}$ & $\begin{array}{l}--\mathrm{R}- \\
---\mathrm{R}- \\
\mathrm{R}--\overline{\mathrm{R}} \\
\mathrm{R}--\mathrm{R}- \\
--\mathrm{R}-\mathrm{C}\end{array}$ & \begin{tabular}{|c|}
----- \\
----- \\
----- \\
$---\mathrm{R}-$ \\
$----\mathrm{R}$ \\
\end{tabular} & $\begin{array}{l}\mathrm{C}---- \\
\mathrm{C}---- \\
\mathrm{C}-\overline{-}- \\
\mathrm{C}-\mathrm{R}-- \\
--\mathrm{F}--\end{array}$ & $\begin{array}{l}----\mathrm{F} \\
----\mathrm{F} \\
----\mathrm{C} \\
---\mathrm{R}- \\
-\mathrm{F}---\end{array}$ & \begin{tabular}{|l|}
----- \\
----- \\
----- \\
----- \\
$\mathrm{R}-\mathrm{R} F-$ \\
\end{tabular} & \begin{tabular}{|l}
$---\mathrm{R}-$ \\
$---\mathrm{R}-$ \\
$---\mathrm{R}-$ \\
$---\mathrm{R}-$ \\
$\mathrm{R}-\mathrm{R}--$
\end{tabular} & $\begin{array}{l}--R_{F} \\
R-\text { R F } \\
R-\text { R F } \\
-- \text { F C } \\
- \text { R }- \text { F } \\
\end{array}$ & \begin{tabular}{l|}
$\mathrm{R}$ \\
$\mathrm{R}$ \\
$\mathrm{C}$ \\
$\mathrm{C}$ \\
$\mathrm{A}$ \\
\end{tabular} & $\begin{array}{l}G \\
G \\
G \\
G \\
G \\
\end{array}$ & \\
\hline $\begin{array}{l}2-5(93-95) \\
3-1(30-32)\end{array}$ & $\begin{array}{l}\mathrm{R}-\overline{\mathrm{R}}-\overline{\mathrm{F}} \\
--\mathrm{F}\end{array}$ & \begin{tabular}{|l|}
$-\mathrm{R}-\mathrm{R}-$ \\
$--\mathrm{F}-$
\end{tabular} & $\mid \begin{array}{l}\mathrm{R}-\cdots-- \\
-\cdots---\end{array}$ & $\left|\begin{array}{l}\mathrm{C}-\cdots \\
\mathrm{A}---\cdots\end{array}\right|$ & $\left|\begin{array}{c}---\mathrm{R} \\
----\mathrm{R}\end{array}\right|$ & $\mid \begin{array}{l}----- \\
-----\end{array}$ & $\mid \begin{array}{l}---R \\
----R\end{array}$ & & \begin{tabular}{l|}
$\mathrm{C}$ \\
$\mathrm{C}$
\end{tabular} & $\begin{array}{l}\mathrm{G} \\
\mathrm{G}\end{array}$ & \\
\hline $\begin{array}{l}3-1(120-122) \\
3-2(44-46) \\
3-2(120-122)\end{array}$ & $\begin{array}{l}R-R-R \\
R-R-R \\
R-R-R\end{array}$ & $\begin{array}{l}-\mathrm{R}-\mathrm{R}- \\
-\mathrm{R}-\mathrm{R}- \\
-\mathrm{R}-\mathrm{R}- \\
\end{array}$ & {$\left[\begin{array}{c}--\mathrm{R}- \\
--\mathrm{R}- \\
---\mathrm{R}-\end{array}\right.$} & $\left|\begin{array}{l}\mathrm{R}---- \\
\mathrm{R}---- \\
\mathrm{R}----\end{array}\right|$ & $\mid \begin{array}{c}--- \text { R R } \\
--- \text { R R } \\
--- \text { R R }\end{array}$ & $\begin{array}{l}----- \\
----- \\
----- \\
\end{array}$ & $\begin{array}{c}---\mathrm{R}- \\
---\mathrm{R}- \\
---\mathrm{R}-\end{array}$ & $\begin{array}{l}--\mathrm{RC} \\
--\mathrm{RC} \\
--\mathrm{RC}\end{array}$ & $\begin{array}{l}\mathrm{A} \\
\mathrm{C} \\
\mathrm{A}\end{array}$ & $\begin{array}{l}\mathrm{G} \\
\mathrm{G} \\
\mathrm{G} \\
\end{array}$ & \multirow{4}{*}{ II } \\
\hline $\begin{array}{l}3-5(34-36) \\
3-6(18-20) \\
4-1(118-120) \\
4-3(130-132) \\
4-4(35-37)\end{array}$ & $\begin{array}{l}R-R-R \\
R-R-R \\
R-R R R \\
R-R-R \\
R-R-R \\
\end{array}$ & $\begin{array}{l}-\mathrm{R}-\mathrm{R}- \\
-\mathrm{R}-\mathrm{R}- \\
-\mathrm{R}-\mathrm{R}- \\
-\mathrm{R}-\mathrm{R}- \\
-\mathrm{R}-\mathrm{R}- \\
\end{array}$ & \begin{tabular}{|l}
$--\mathrm{R}-$ \\
$---\mathrm{R}-$ \\
$---\mathrm{R}-$ \\
$---\mathrm{R}-$ \\
$---\mathrm{R}-$ \\
\end{tabular} & $\begin{array}{l}\mathrm{C}---- \\
\mathrm{C}---- \\
\mathrm{C}---- \\
\mathrm{C}---- \\
\mathrm{C}----\end{array}$ & $\begin{array}{l}--- \text { R } \\
--- \text { R R } \\
--- \text { R R } \\
--- \text { R R } \\
--- \text { R R } \\
\end{array}$ & $\begin{array}{l}----- \\
----- \\
----- \\
----- \\
----- \\
\end{array}$ & $\begin{array}{c}---\mathrm{R}- \\
---\mathrm{R}- \\
---\mathrm{R}- \\
---\mathrm{R}- \\
---\mathrm{R} R\end{array}$ & $\begin{array}{l}--\mathrm{RC} \\
--\mathrm{R} C \\
--\mathrm{RC} \\
--\mathrm{RC} \\
--\mathrm{RC}\end{array}$ & \begin{tabular}{l|}
$\mathrm{C}$ \\
$\mathrm{C}$ \\
$\mathrm{A}$ \\
$\mathrm{A}$ \\
$\mathrm{C}$ \\
\end{tabular} & $\begin{array}{l}G \\
G \\
G \\
G \\
M \\
\end{array}$ & \\
\hline $\begin{array}{l}4(C C) \\
5-1(35-37) \\
5-1(85-87) \\
5-2(43-45) \\
5-5(120-122)\end{array}$ & $\begin{array}{l}R-R-F \\
R-R-R \\
R-R-R \\
--R-R \\
R-R R R\end{array}$ & \begin{tabular}{|l|}
$-\mathrm{R}-\mathrm{R}-$ \\
$---\mathrm{R}-$ \\
$---\mathrm{R}-$ \\
$---\mathrm{R}-$ \\
$---\mathrm{R}-$ \\
\end{tabular} & $\begin{array}{c}---\mathrm{R}- \\
---\mathrm{R}- \\
---\mathrm{R} \\
----- \\
---\mathrm{R}\end{array}$ & $\begin{array}{l}\mathrm{C}---- \\
\mathrm{F}---- \\
\mathrm{F}---- \\
\mathrm{F}---- \\
\mathrm{R}----\end{array}$ & $\begin{array}{c}--- \text { R R } \\
--- \text { R R } \\
--- \text { R R } \\
--- \text { R R } \\
--- \text { R R } \\
\end{array}$ & \begin{tabular}{|l|}
----- \\
----- \\
----- \\
----- \\
$--\mathrm{R}--$ \\
\end{tabular} & \begin{tabular}{|c|}
$---\mathrm{R} R$ \\
$---\mathrm{R}-$ \\
$----\mathrm{R}$ \\
$----\mathrm{R}$ \\
$---\mathrm{R}-$ \\
\end{tabular} & $\begin{array}{l}-- \text { R }- \\
- \text { R R F } \\
-- \text { R F } \\
-- \text { R F } \\
-- \text { R R }\end{array}$ & \begin{tabular}{|l|}
$\mathrm{C}$ \\
$\mathrm{C}$ \\
$\mathrm{C}$ \\
$\mathrm{R}$ \\
$\mathrm{R}$ \\
\end{tabular} & $\begin{array}{l}G \\
G \\
G \\
M \\
G \\
\end{array}$ & \\
\hline $\begin{array}{l}5-6(93-95) \\
5-6(113-115) \\
6-2(35-37) \\
6-2(120-122)\end{array}$ & $\begin{array}{l}R-R-R \\
R-R-R \\
----R \\
--R-R\end{array}$ & \begin{tabular}{|c|}
$---\mathrm{R}-$ \\
$---\mathrm{R}-$ \\
$---\overline{\mathrm{R}}-$ \\
$---\mathrm{R}-$
\end{tabular} & $\begin{array}{c}--\mathrm{R}- \\
-\cdots-- \\
----- \\
---\mathrm{R}-\end{array}$ & $\mid \begin{array}{l}F-\cdots-- \\
F---- \\
F----\end{array}$ & $\mid \begin{array}{c}--- \text { R R } \\
--- \text { R R } \\
--- \text { R } \\
--- \text { R R }\end{array}$ & $\begin{array}{l}--\mathrm{R}-- \\
----- \\
--\mathrm{R}-- \\
--\mathrm{R}--\end{array}$ & \begin{tabular}{|c|}
$---\overline{-}$ \\
$---\mathrm{R}-$ \\
----- \\
-----
\end{tabular} & $\begin{array}{l}-- \text { R R } \\
-- \text { R R } \\
-- \text { R F } \\
-- \text { F F }\end{array}$ & $\begin{array}{l}\mathrm{R} \\
\mathrm{R} \\
\mathrm{R} \\
\mathrm{R}\end{array}$ & $\begin{array}{l}\mathrm{G} \\
\mathrm{G} \\
\mathrm{M} \\
\mathrm{M}\end{array}$ & \\
\hline $7-1(100-102)$ & & $\mathrm{R} \ldots-\cdots$ & $-\cdots \mathrm{R}-$ & $A \ldots-\cdots$ & $-\ldots-\mathrm{R} \mathrm{R}$ & ----- & $---\mathrm{R}-$ & $-\mathrm{RFC}$ & $\mathrm{C}$ & G & III \\
\hline $\begin{array}{l}7-2(65-67) \\
7-2(120-122) \\
7-3(70-72) \\
7-4(59-61) \\
7-4(76-78) \\
\end{array}$ & $\begin{array}{l}\mathrm{R}-\mathrm{F}-\mathrm{R} \\
\mathrm{R}-\mathrm{F}-- \\
\mathrm{R}-\mathrm{F}- \\
--\mathrm{R}-- \\
--\mathrm{R}--\end{array}$ & $\begin{array}{l}\text { R R }-\mathrm{R}- \\
\text { R R }-\mathrm{R}- \\
\mathrm{R} R-\mathrm{R}- \\
\mathrm{R}--\overline{-} \\
\mathrm{R} \mathrm{R}-\mathrm{F}-\end{array}$ & $\mid$\begin{tabular}{c}
$---\mathrm{R}-$ \\
$---\mathrm{R}-$ \\
\hdashline$--\mathrm{R}$ \\
$\mathrm{R}--\mathrm{R}-$ \\
$---\mathrm{R}-$
\end{tabular} & $\mid \begin{array}{l}\mathrm{A}---- \\
\mathrm{A}---- \\
\mathrm{A}--- \\
\mathrm{A}--\mathrm{R}- \\
\mathrm{C}----\end{array}$ & $\mid \begin{array}{c}--- \text { R R } \\
--- \text { R R } \\
--- \text { R R } \\
--- \text { R F } \\
--- \text { C R }\end{array}$ & $\begin{array}{l}----- \\
----- \\
----- \\
--\mathrm{R}-- \\
--\mathrm{R}--\end{array}$ & $\begin{array}{c}---\mathrm{R}- \\
---\mathrm{R}- \\
---\mathrm{R}- \\
---\mathrm{R} R \\
\mathrm{R}--\mathrm{R} \mathrm{R}\end{array}$ & $\begin{array}{l}- \text { R R C } \\
- \text { R R C } \\
- \text { R F C } \\
- \text { R F C } \\
- \text { R F C }\end{array}$ & \begin{tabular}{l|}
$\mathrm{C}$ \\
$\mathrm{A}$ \\
$\mathrm{A}$ \\
$\mathrm{A}$ \\
$\mathrm{A}$
\end{tabular} & $\begin{array}{l}\mathrm{G} \\
\mathrm{G} \\
\mathrm{G} \\
\mathrm{G} \\
\mathrm{G}\end{array}$ & \multirow[b]{2}{*}{ IV } \\
\hline $\begin{array}{l}7-4(130-132) \\
7-5(105-107) \\
7-5(133-135) \\
7(C C) \\
8-2(90-92)\end{array}$ & $\begin{array}{l}--R-- \\
R-R-R \\
R-R-R \\
R-R-F\end{array}$ & \begin{tabular}{|l|} 
F R $-F-$ \\
- \\
R R $-F-$ \\
F R $-F-$ \\
F R $-F-$
\end{tabular} & \begin{tabular}{|c|}
----- \\
----- \\
----- \\
----- \\
----- \\
\end{tabular} & $\mid \begin{array}{l}\mathrm{R}---- \\
\mathrm{C}---- \\
\mathrm{C}---- \\
\mathrm{A}---- \\
\mathrm{A}----\end{array}$ & \begin{tabular}{|l}
--- C R \\
--- R F \\
--- R F \\
--- R F \\
--- R F
\end{tabular} & \begin{tabular}{|l|}
$--\mathrm{R}--$ \\
----- \\
$--\mathrm{R}--$ \\
$--\mathrm{R}--$ \\
$--\mathrm{R}--$ \\
\end{tabular} & $\begin{array}{c}\mathrm{R}--\mathrm{R} R \\
---\mathrm{F}- \\
---\mathrm{F}- \\
---\mathrm{F}- \\
---\mathrm{F}-\end{array}$ & $\begin{array}{l}-\mathrm{R} F \mathrm{C} \\
--\mathrm{RC} \\
--\mathrm{RC} \\
--\mathrm{RC} \\
--\mathrm{RC}\end{array}$ & \begin{tabular}{l|}
$\mathrm{C}$ \\
$\mathrm{C}$ \\
$\mathrm{C}$ \\
$\mathrm{C}$ \\
$\mathrm{C}$ \\
\end{tabular} & $\begin{array}{l}G \\
G \\
G \\
G \\
M\end{array}$ & \\
\hline $\begin{array}{l}8-2(130-132) \\
8-3(40-42) \\
8-3(134-136) \\
9-1(5-7) \\
9-1(90-92) \\
\end{array}$ & $\begin{array}{l}\mathrm{R}-\mathrm{R}-\mathrm{F} \\
\mathrm{R}-\mathrm{R}-\mathrm{R} \\
\mathrm{R}---- \\
\mathrm{R}---- \\
-----\end{array}$ & $\begin{array}{l}\text { F R - F - } \\
\text { F R - F - } \\
\text { R R - R - } \\
\text { R - - R - } \\
\text { R - - R - }\end{array}$ & \begin{tabular}{|c|}
----- \\
----- \\
----- \\
----- \\
----- \\
\end{tabular} & \begin{tabular}{|l|}
$\mathrm{A}----$ \\
$\mathrm{F}$ R --- \\
$\mathrm{C}--\mathrm{R}$ \\
$\mathrm{C} \mathrm{R}--\mathrm{R}$ \\
$\mathrm{C} \mathrm{R}--\mathrm{R}$
\end{tabular} & \begin{tabular}{|l}
$---\mathrm{R} F$ \\
$-\mathrm{R}--\mathrm{R}$ \\
$-\mathrm{F}--\mathrm{R}$ \\
$-\mathrm{F}--\mathrm{R}$ \\
$-\mathrm{F}--\mathrm{R}$
\end{tabular} & \begin{tabular}{|l|}
$--\mathrm{R}--$ \\
----- \\
$--\mathrm{R}--$ \\
$--\mathrm{R}--$ \\
$--\mathrm{R}--$ \\
\end{tabular} & $\begin{array}{l}---\mathrm{F}- \\
---\mathrm{R} R \\
---\mathrm{R}- \\
---\mathrm{R}- \\
----\mathrm{R} \\
\end{array}$ & $\begin{array}{l}-- \text { R C } \\
-- \text { R C } \\
-- \text { R A } \\
-- \text { R A } \\
--- \text { A } \\
\end{array}$ & \begin{tabular}{l|}
$\mathrm{A}$ \\
$\mathrm{A}$ \\
$\mathrm{R}$ \\
$\mathrm{C}$ \\
$\mathrm{C}$ \\
\end{tabular} & $\begin{array}{l}\mathrm{G} \\
\mathrm{G} \\
\mathrm{M} \\
\mathrm{G} \\
\mathrm{G} \\
\end{array}$ & V \\
\hline $\begin{array}{l}9-2(17-19) \\
9-2(110-112) \\
9-3(38-40) \\
9-4(33-35) \\
9-4(140-141)\end{array}$ & $\begin{array}{l}----- \\
\mathrm{R}---\mathrm{R} \\
\mathrm{R}---\overline{\mathrm{R}} \\
\mathrm{R}-----\end{array}$ & 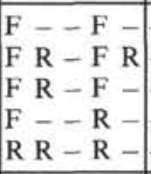 & $\begin{array}{c}----- \\
-\cdots--- \\
---\mathrm{R}- \\
----- \\
----- \\
\end{array}$ & \begin{tabular}{|l|}
$\mathrm{R}----$ \\
$\mathrm{C}$ R --- \\
$\mathrm{C} \mathrm{R} \mathrm{R}--$ \\
$\mathrm{C} \mathrm{R}---$ \\
$\mathrm{F}----$
\end{tabular} & $\begin{array}{l}-\mathrm{R}--\mathrm{R} \\
-\mathrm{F}--\mathrm{R} \\
-\mathrm{R}--- \\
-\mathrm{F}--- \\
-\mathrm{R}---\end{array}$ & \begin{tabular}{|l|}
----- \\
----- \\
----- \\
----- \\
----- \\
\end{tabular} & $\begin{array}{c}---\mathrm{R} R \\
--- \text { F R } \\
----- \\
---\mathrm{R}- \\
---\mathrm{R}- \\
\end{array}$ & $\begin{array}{l}---\mathrm{C} \\
--\mathrm{RA} \\
---\mathrm{C} \\
---\mathrm{C} \\
-\mathrm{R} R \mathrm{C}\end{array}$ & \begin{tabular}{l|}
$\mathrm{C}$ \\
$\mathrm{C}$ \\
$\mathrm{C}$ \\
$\mathrm{C}$ \\
$\mathrm{C}$ \\
\end{tabular} & $\begin{array}{l}G \\
G \\
G \\
G \\
G \\
\end{array}$ & \multirow{3}{*}{ VI } \\
\hline $\begin{array}{l}9-5(53-55) \\
9-5(113-115) \\
9-6(56-58) \\
9-6(125-127) \\
10-4(27-29) \\
\end{array}$ & $\begin{array}{l}\mathrm{R}---- \\
\mathrm{R}---- \\
\mathrm{R}---\mathrm{R} \\
----- \\
----\mathrm{R}\end{array}$ & $\begin{array}{l}\text { R R - R - } \\
\text { R R - R R } \\
\text { R R - R R } \\
\text { F - F - } \\
\text { F - - R - }\end{array}$ & \begin{tabular}{|l|}
------ \\
----- \\
----- \\
----- \\
-----
\end{tabular} & $\begin{array}{l}\text { F R }--- \\
\text { F R }--- \\
\text { F R }--- \\
\text { F }---- \\
\text { R R }---\end{array}$ & \begin{tabular}{|l|}
$-\mathrm{R}---$ \\
$-\mathrm{R}---$ \\
$-\mathrm{F}---$ \\
$-\mathrm{F}---$ \\
$-\mathrm{F}---$
\end{tabular} & \begin{tabular}{|l|}
$--\mathrm{R}--$ \\
----- \\
----- \\
----- \\
------ \\
\end{tabular} & \begin{tabular}{|l|}
$---\mathrm{R}-$ \\
----- \\
----- \\
----- \\
$---\mathrm{R}-$
\end{tabular} & $\begin{array}{l}--\mathrm{RC} \\
--\mathrm{RC} \\
--\mathrm{RC} \\
-\mathrm{R} \mathrm{RC} \\
-\mathrm{R} \mathrm{RC} \\
\end{array}$ & \begin{tabular}{l|}
$\mathrm{R}$ \\
$\mathrm{C}$ \\
$\mathrm{C}$ \\
$\mathrm{C}$ \\
$\mathrm{R}$
\end{tabular} & $\begin{array}{l}G \\
G \\
G \\
G \\
G \\
\end{array}$ & \\
\hline $\begin{array}{l}104-(51-53) \\
10(\mathrm{CC})\end{array}$ & $\begin{array}{l}\mathrm{R}---\mathrm{R} \\
\mathrm{R}---\mathrm{R}\end{array}$ & 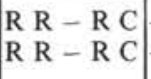 & $\mid \begin{array}{c}-\cdots \\
-----1\end{array}$ & $\mid \begin{array}{l}\mathrm{R}-\cdots-- \\
\mathrm{R}-----\end{array}$ & $\mid \begin{array}{l}\text { R R - - - } \\
\text { R R - - - }\end{array}$ & $\begin{array}{l}----- \\
-----\end{array}$ & $\left|\begin{array}{l}----- \\
-----\end{array}\right|$ & $\begin{array}{l}-\mathrm{R}-\mathrm{F} \\
-\mathrm{R}-\mathrm{F}\end{array}$ & $\begin{array}{l}\mathrm{R} \\
\mathrm{C}\end{array}$ & $\begin{array}{l}M \\
G\end{array}$ & \\
\hline
\end{tabular}


generally low within most parts of the section (characteristic of subarctic assemblages). Recovered thanatocoenoses belong to the recurrent group II representing the Subarctic Diatom Assemblage of Kanaya and Koizumi (1966).

According to the radiometric-paleomagnetic time scale of the NPD zones, a sedimentation rate of 37 meters/m.y. could be assigned for the interval from 0 to 92 meters below the sea floor (Figure 36).

\section{Site 180}

Diatoms are rare to absent in most samples collected from Site 180 except for those (listed in Table 6) which contained a moderately to well-preserved diatom flora with common to abundant individuals. The best samples came from $179-20-4(86-88 \mathrm{~cm})$. Three warm periods are found within this section (see "Paleoclimatic Interpretation," this report). No older reworked diatoms occurred in the recovered section. Sporadic displacement of a few littoralmarine diatoms was found in the warmer intervals. Detailed lists of diatom taxa in the samples are given in Table 6.

The base of NPD Zone I was not recognized within the upper 450 meters below the sea floor. None of the NPD Zone I base indicators were found even though the lowest samples were concentrated and sieved in efforts to detect the latest occurrence of Rhizosolenia curvirostris. Thus the cored interval from 0 to 470 meters is younger than 0.26 m.y. This is consistent with the low abundance of hemipelagic to pelagic sediment layers within the sequence of graded silts, fine sands, and muds.

Species diversity was low throughout the hole, which is characteristic for the subarctic biofacies. Recovered thanatocoenoses belong to the recurrent group II representing the Subarctic Diatom Assemblage of Kanaya and Koizumi (1966).

The calculated minimum sedimentation rate, as determined by the absolute date for the base of NPD Zone I of 0.26 m.y., is 1700 meters/m.y. for the interval 0 to 470 meters below the sea floor (Figure 36).

\section{Site 181}

A sequence of 369 meters of muds, silty muds, thin sands, and diatomaceous muds was cored continuously at Site 181. Cores 1 to 3 contain a well-preserved, abundant to rare, diatom flora; Cores 4 through 8 are barren; Cores 9 to 21 contain a poorly to well-preserved, abundant to rare, diatom flora. A nearly pure diatom-rich mud was recovered from certain levels $(181-1-1,70-72 \mathrm{~cm}, 181-1-6,78-80 \mathrm{~cm}$, $181-2-3,21-23 \mathrm{~cm}, 181-12-3,119-21 \mathrm{~cm}, 181-13-3,40-42$ $\mathrm{cm}, 181-14$, CC, 181-18-2, 20-22 cm, 181-18-3, 30-32 cm, and 181-18-4, 14-16 cm). (See Table 7).

Species diversity is generally low as is characteristic of subarctic assemblages. No older reworked microfossils are found within the sequence.

Based on the radiometric-paleomagnetic time scale of the NPD zones, a sedimentation rate of 200 meters/m.y. was calculated for the interval from 0 to 165.5 meters below the sea floor. No Rhabdonema arcuatum Zone was found, but this may result from sampling procedures and/or incomplete core recovery (Figures 34 and 36).

The base of NPD Zone I is at 104 meters $(181-11, \mathrm{CC})$ and of NPD Zone II, at 165.5 meters $(181-18-4,14-16 \mathrm{~cm})$.
The base of NPD Zone III could not be recognized as the interval from $181-21-1(51-53 \mathrm{~cm})$ to $181-30-1(33-34 \mathrm{~cm})$ was barren of diatoms. The oldest recovered diatom-bearing sediment $(181-21-1,25 \mathrm{~cm})$ belongs to NPD Zone III.

\section{Site 182 (Holes 182 and 182A)}

A sequence of 166.5 meters of sand- and gravel-rich muds, including glacial erratics, was cored discontinuously at Site 182. No paleoclimatic investigations were made due to poor recovery (11.5 meters at Hole 182 and only a core catcher sample at Hole 182A). Diatoms were found in varying abundance with good to poor preservation (see Table 8). One occurrence of a warmer biofacies was encountered in NPD Zone II (182-3-1, 53-55 cm). Species diversity was generally low within the section (subarctic assemblage). No reworked older microfossils were found in the examined samples.

The base of NPD Zone $I$ is at 9.5 meters $(182-1 \mathrm{CC})$ and of NPD Zone II, at 63 meters $(182-3-2,109-111 \mathrm{~cm})$; the base of NPD Zone III was not recognized. The oldest recovered sediment at Hole 182A (166.5 meters below the sea floor) falls within NPD Zone III with an age younger than 1.3 m.y.

Thalassiosira nidulus occurs within NPD Zone III and seems to be a good marker, together with Rhizosolenia curvirostris, for the Middle Pleistocene in high latitudes.

Based on the radiometric-paleomagnetic time scale of the NPD zones, a sedimention rate of 62.5 meters/m.y. can be assigned to the 63 -meter interval immediately below the sea floor (Figure 36 ).

\section{Lower Wildcat Group}

A section equivalent to part of that drilled at Site 173 was collected along Mattole Road, South of Ferndale, Humboldt County, California. This sequence belongs to the lower portion of the Wildcat Group. The base of the Pliocene section is a Cretaceous metasediment (Yager Formation) which is in fault contact with the overlying Pullen Formation. The Pullen Formation is overlain successively by the Eel River and Rio Dell Formations.

Samples 1 and 2 (Figure 29) contain poorly preserved diatom specimens which have been partly recrystallized and show quartzitic structure. Only faint indications of surface topography remained of the original structure. The Coscinodiscus marginatus-Coscinodiscus species Group can be identified. These individuals have a wide stratigraphic range and no correlation with the North Pacific Diatom Zones established at Site 173 is possible.

\section{TIME RANGES OF SELECTED DIATOM TAXA AND BIOSTRATIGRAPHIC ZONATION}

In order to establish levels of correlation between the various sequences cored and to determine a diatom zonation for the North Pacific, selected diatom events (upper and lower limits of occurrence of taxa and evolutionary transitions) were arranged in chronological order for Sites 173 (Figure 1) and 178 (Figure 3). These were then used to define North Pacific Diatom Zones I through XXV. Most of these zones are represented only at Site 173, but intensive study on available land sections from Japan, California, and Kamchatka and the results of DSDP Leg 19 will permit 
TABLE 6

Diatoms at Site 180

\begin{tabular}{|c|c|c|c|c|c|c|c|c|c|c|c|c|c|c|c|}
\hline Sample & 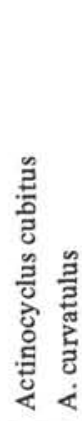 & $\frac{\pi}{3}$ & 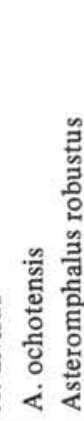 & 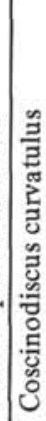 & & 造 & 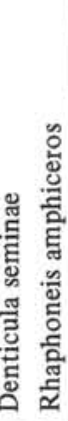 & 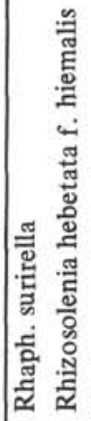 & 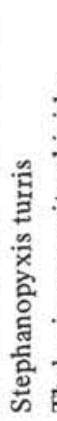 & 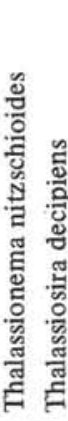 & 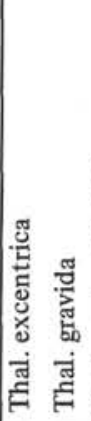 & 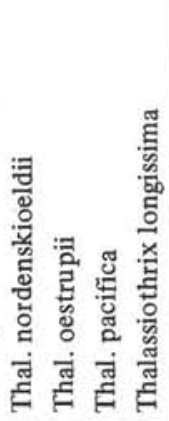 & 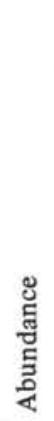 & 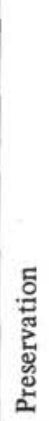 & 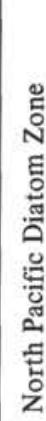 \\
\hline $\begin{array}{l}1-1(82-84) \\
1-2(109-110) \\
1-3(26-28) \\
3(C C) \\
4-1(39-41)\end{array}$ & $\begin{array}{l}-- \\
-- \\
-- \\
-- \\
--\end{array}$ & $\begin{array}{l}- \\
- \\
- \\
- \\
-\end{array}$ & $\begin{array}{l}\mathrm{R}- \\
\overline{\mathrm{R}} \mathrm{R} \\
- \\
-\end{array}$ & $\begin{array}{l}- \\
\mathrm{R} \\
- \\
- \\
-\end{array}$ & $\begin{array}{l}\bar{R} \\
\bar{R} \\
\mathrm{R}\end{array}$ & $\begin{array}{l}-\mathrm{C} \\
\mathrm{R} \\
-\mathrm{F} \\
-\mathrm{F} \\
-\mathrm{F}\end{array}$ & $\begin{array}{l}\mathrm{C}- \\
\mathrm{F}- \\
\mathrm{C}- \\
\mathrm{F}- \\
\mathrm{F}-\end{array}$ & $\begin{array}{l}-\mathrm{R} \\
-\mathrm{R} \\
-- \\
-\overline{\mathrm{R}}\end{array}$ & $\begin{array}{l}\mathrm{R} \\
- \\
- \\
- \\
-\end{array}$ & $\begin{array}{l}- \\
- \\
- \\
- \\
-\end{array}$ & $\begin{array}{l}-\mathrm{R} \\
-\quad- \\
-\mathrm{F} \\
-\mathrm{R} \\
- \\
-\end{array}$ & $\begin{array}{l}--\mathrm{RC} \\
--\mathrm{RC} \\
---\mathrm{C} \\
--\bar{C} \\
--\mathrm{RC}\end{array}$ & $\begin{array}{l}\mathrm{C} \\
\mathrm{C} \\
\mathrm{R} \\
\mathrm{R} \\
\mathrm{R}\end{array}$ & $\mathrm{M}$ & \\
\hline $\begin{array}{l}15-2(98-100) \\
15(C C) \\
16-1(92-94) \\
17-3(33-35) \\
17-3(98-100)\end{array}$ & $\begin{array}{l}-\mathrm{R} \\
-\mathrm{R} \\
-\overline{\mathrm{R}} \\
-\mathrm{R}\end{array}$ & $\begin{array}{l}\mathrm{R} \\
\mathrm{R} \\
- \\
\mathrm{R} \\
-\end{array}$ & $\begin{array}{ll}\mathrm{R} & \mathrm{R} \\
\mathrm{R} & \mathrm{R} \\
\overline{\mathrm{R}} & \overline{\mathrm{R}} \\
\mathrm{R} & \mathrm{R}\end{array}$ & $\begin{array}{l}\mathrm{R} \\
\mathrm{R} \\
\mathrm{R} \\
\mathrm{R} \\
\mathrm{R}\end{array}$ & $\begin{array}{l}\mathrm{R} \\
\mathrm{R} \\
\mathrm{C} \\
\mathrm{R} \\
\mathrm{R}\end{array}$ & $\begin{array}{ll}R & F \\
R & F \\
- & C \\
R & C \\
R & C \\
\end{array}$ & $\begin{array}{l}\mathrm{F}- \\
\mathrm{F}- \\
\mathrm{C}- \\
\mathrm{C}- \\
\mathrm{C}-\end{array}$ & $\begin{array}{ll}\mathrm{R} & \mathrm{R} \\
\mathrm{R} & \mathrm{R} \\
- & \mathrm{C} \\
\mathrm{R} & \mathrm{C} \\
- & \mathrm{C} \\
\end{array}$ & $\begin{array}{l}\mathrm{R} \\
\mathrm{R} \\
- \\
- \\
\mathrm{R}\end{array}$ & $\begin{array}{ll}\mathrm{R} & - \\
\mathrm{R} & - \\
\mathrm{R} & - \\
\mathrm{R} & \mathrm{R} \\
- & -\end{array}$ & $\begin{array}{ll}\mathrm{R} & \mathrm{F} \\
\mathrm{R} & \mathrm{F} \\
- & \mathrm{C} \\
\mathrm{C} & \mathrm{R} \\
\mathrm{R} & \mathrm{C} \\
\end{array}$ & $\begin{array}{llll}R & R & C & R \\
R & R & C & R \\
R & - & R & C \\
- & - & R & C \\
- & - & R & C\end{array}$ & $\begin{array}{l}\mathrm{C} \\
\mathrm{C} \\
\mathrm{F} \\
\mathrm{C} \\
\mathrm{C}\end{array}$ & M & \\
\hline $\begin{array}{l}17-4(110-112) \\
18-1(70-72) \\
18-3(83-85) \\
18-4(93-95) \\
18(C C) \\
19-1(95-97) \\
19-2(78-80) \\
20-2(120-122) \\
20-4(40-42) \\
20-4(86-88) \\
20-5(80-82) \\
25-1(112-114)\end{array}$ & $\begin{array}{l}-\bar{R} \\
-\bar{R} \\
-\bar{R} \\
-R \\
-\bar{R} \\
-R \\
-- \\
-\bar{R} \\
=R \\
-\bar{R}\end{array}$ & $\begin{array}{l}\mathrm{R} \\
- \\
\bar{R} \\
\mathrm{R} \\
\mathrm{R} \\
\overline{\mathrm{R}} \\
\overline{\mathrm{R}} \\
- \\
-\end{array}$ & 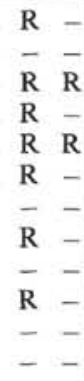 & $\begin{array}{l}\bar{R} \\
\bar{R} \\
\bar{R} \\
\bar{R} \\
\bar{R} \\
\bar{R} \\
\bar{R} \\
- \\
-\end{array}$ & $\begin{array}{l}\mathrm{C} \\
\mathrm{R} \\
\mathrm{C} \\
\mathrm{R} \\
\mathrm{R} \\
\mathrm{C} \\
\mathrm{C} \\
\mathrm{C} \\
\mathrm{C} \\
\mathrm{C} \\
\mathrm{C} \\
\mathrm{C}\end{array}$ & $\begin{array}{ll}R & - \\
R & C \\
- & R \\
R & R \\
R & R \\
R & C \\
- & C \\
R & C \\
- & C \\
R & C \\
- & C \\
- & R\end{array}$ & $\begin{array}{l}-\bar{l} \\
\mathrm{C}- \\
\mathrm{R}- \\
\mathrm{R} \text { R } \\
\mathrm{R} \text { R } \\
\mathrm{C}- \\
\mathrm{C}- \\
\mathrm{C}- \\
\mathrm{C}- \\
\mathrm{C}- \\
\mathrm{C}- \\
\mathrm{R}-\end{array}$ & $\begin{array}{ll}\mathrm{R} & - \\
- & \mathrm{F} \\
\mathrm{R} & - \\
\mathrm{R} & \mathrm{R} \\
\mathrm{R} & \mathrm{F} \\
- & \mathrm{R} \\
- & \mathrm{C} \\
- & \mathrm{R} \\
- & \mathrm{C} \\
- & \mathrm{F} \\
- & \mathrm{C} \\
- & \mathrm{F}\end{array}$ & $\begin{array}{l}\bar{R} \\
\bar{R} \\
\mathrm{R} \\
\overline{\mathrm{R}} \\
- \\
\overline{\mathrm{R}} \\
- \\
-\end{array}$ & 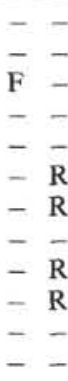 & $\begin{array}{ll}C & - \\
R & C \\
-\bar{R} & \bar{C} \\
R & C \\
- & R \\
R & R \\
- & R \\
- & R \\
R & R \\
- & \bar{R} \\
- & R\end{array}$ & $\begin{array}{llll}R & F & C & C \\
R & - & R & F \\
- & C & R & R \\
- & R & C & C \\
R & R & C & R \\
- & - & R & C \\
R & - & R & C \\
- & R & R & C \\
- & - & R & C \\
R & R & C & C \\
- & - & R & C \\
- & R & R & C\end{array}$ & $\begin{array}{l}\mathrm{F} \\
\mathrm{F} \\
\mathrm{F} \\
\mathrm{C} \\
\mathrm{C} \\
\mathrm{R} \\
\mathrm{R} \\
\mathrm{R} \\
\mathrm{R} \\
\mathrm{A} \\
\mathrm{R} \\
\mathrm{R}\end{array}$ & M & 1 \\
\hline
\end{tabular}


TABLE 7

Diatoms at Site 181

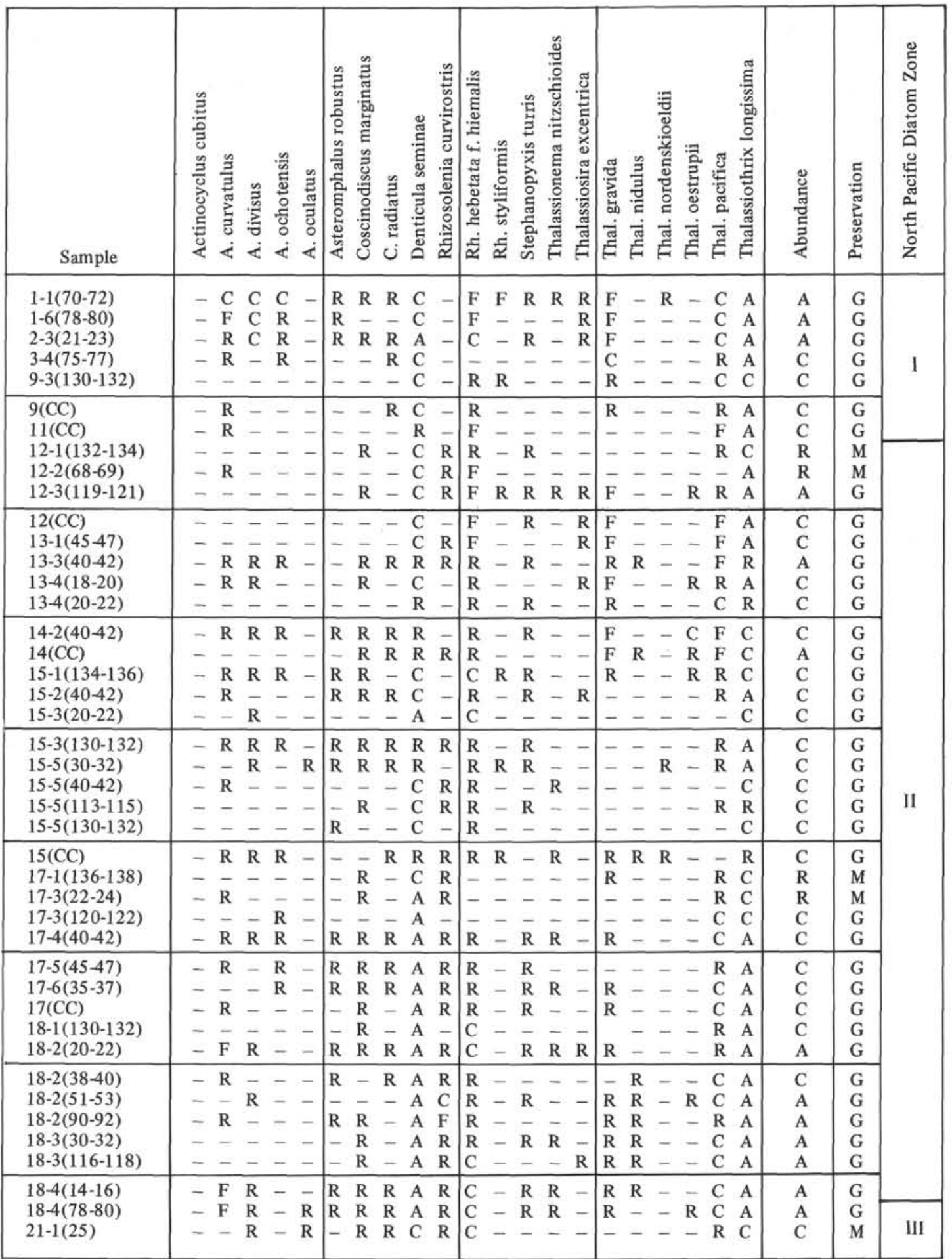


TABLE 8

Diatoms at Site 182

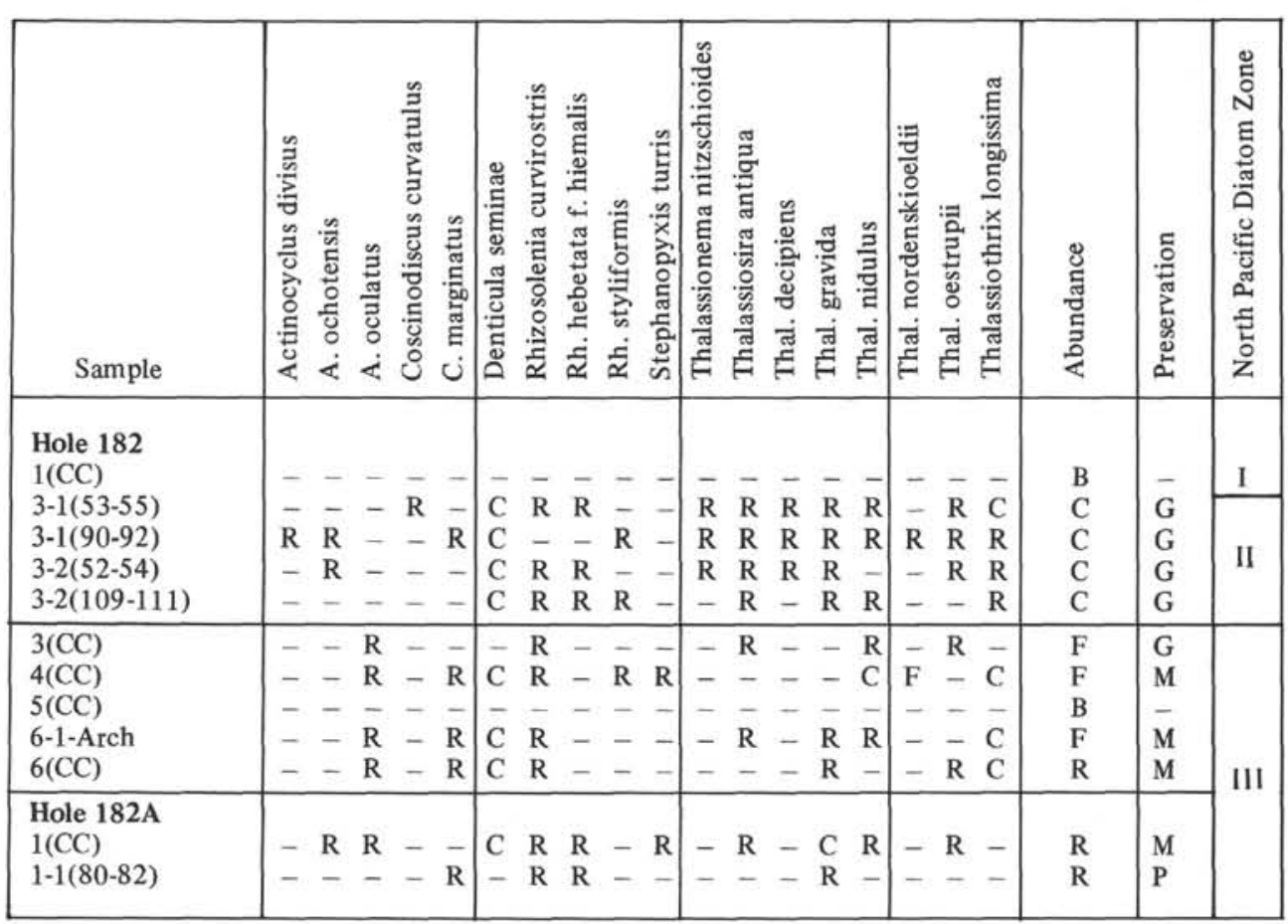


further refinement of the zones. Poor preservation and recovery at Site 178 prevented reliable application of the zonation in the Pliocene-Miocene interval in the Gulf of Alaska.

The zonation of Donahue (1970) was used to subdivide the Pleistocene to Upper Pliocene interval. Correlation of Site 173 with the Experimental Mohole sequence (Kanaya, 1971; Martini, 1972 personal communication; Schrader, in press), and the Equatorial Pacific zonation of Burckle (1972) was used to establish the Pliocene-Miocene zonation. Correlations with the planktonic foraminiferal zonation of Blow (1969), the nannoplankton zonation of Martini (1971), and the radiolarian zonations of Hays (1970), and Riedel and Sanfilippo (1971) were made by comparison with diatom sequences from the tropical Pacific, the northern Pacific, and Japanese land sections. Estimated radiometric-paleomagnetic ages of the diatom zones were based on information from Donahue (1970), Burckle (1972), Kanaya and Koizumi (1970), and Berggren (1969, 1972). Boundaries based on diatoms for MiddleUpper Miocene, Pliocene-Miocene, and Pleistocene-Pliocene have been defined by Burckle (1972), and have been used in this paper.

Some question arises as to placement of the PliocenePleistocene boundary which was taken by Burckle (1969) as the evolution of Pseudoeunotia doliolus from its ancestor Nitzschia fossilis. At this same level another transition occurs in the North Pacific where Rhizosolenia curvirostris evolves from its ancestor Rhizosolenia barboi. Comparing the Td values at this level at various sites indicates that, at the base of NPD Zone IV (Pliocene-Pleistocene boundary), a temperature transition from cold to warm to cold took place. On the other hand, a strong cooling occurs in equatorial Pacific cores over the Olduvai event. This cooling should be used to define the Pliocene-Pleistocene boundary instead of the previously mentioned datum level (Burckle, 1972 personal communication). Donahue (1970) also found high Td values in cores V 21-148, RC 10-203, and V 20-107 occurring over the Olduvai event in the northwestern Pacific.

\section{North Pacific Diatom Zone I}

Definition: The base of this zone is defined at the extinction of Rhizosolenia curvirostris.

Discussion: An essentially modern flora is present throughout the zone includes Actinocyclus curvatulus, $A$. ochotensis, Coscinodiscus radiatus (temperate element), Denticula seminae, Nitzschia marina (temperate element), Rhaphoneis cocconeides, Roperia tesselata (temperate element), Stephanopyxis dimorpha, Thalassionema nitzschioides, Thalassiosira decipiens, $T$. excentrica, T. oestrupii, Thalassiothrix frauenfeldii, T. longissima, and Biddulphia aurita.

Subzones: No subzones have been defined.

Paleomagnetic stratigraphy: The base of this zone falls within the middle part of the Brunhes Normal epoch and ranges to the top of the Brunhes Normal epoch.

Comparison with zonations of other workers: Zone I correlates with the Denticula seminae Zone of Donahue (1970); with Horizons I through III of Jousé (1971), with the upper part of the Pseudoeunotia doliolus
Range-zone of Burckle (1972); and with the upper part of the Eucyrtidium tumidulum radiolarian zone of Hays (1970).

Absolute age: 0.0 to 0.26 m.y. (Donahue, 1970).

Geographical extent: Found in North Pacific sediments.

Type locality: DSDP Leg 18, Site 173, Sample 1-1 $(110-111 \mathrm{~cm})$ to Sample 2-2 $(104-105 \mathrm{~cm})$.

\section{North Pacific Diatom Zone II}

Definition: The base of this zone is placed immediately above the extinction of Actinocyclus oculatus; the top at the extinction of Rhizosolenia curvirostris.

Discussion: A modern flora, present throughout the zone, includes Actinocyclus curvatulus, A. ochotensis (present only in the upper part of the zone), Coscinodiscus marginatus (cold element), Coscinodiscus radiatus (temperate element), C. tabularis var. egregius, Denticula seminae, Hemidiscus cuneiformis (temperate element), Pseudoeunotia doliolus (temperate element), Rhizosolenia curvirostris, $R$. styliformis, $R$. bergonii (temperate element), $R$. hebetata forma hiemalis, Stephanopyxis dimorpha, Thalassionema nitzschioides, Thalassiosira excentrica, T. gravida, T. oestrupii, $T$. pacifica, Thalassiothrix frauenfeldii, T. longissima, and Biddulphia aurita.

Subzones: Three subzones are recognized. The top of the lowest subzone, $A$, is defined as the last appearance of Nitzschia reinholdii; the middle subzone, $B$, extends from the top of Nitzschia reinholdii through an interval lacking Actinocyclus ochotensis; the upper subzone, $C$, extends from the reappearance (not evolutionary) of Actinocyclus ochotensis to the top of the zone.

Paleomagnetic stratigraphy: This zone ranges from the Jaramillo event of the Matuyama Reversed epoch to the middle part of the Brunhes Normal epoch.

Comparison with Zonations of other workers: Zone II correlates with the Rhizosolenia curvirostris Zone of Donahue (1970), with Horizons IV through VI of Jousé (1971), and with the lower part of the Eucyrtidium tumidulum radiolarian zone of Hays (1970). It falls within the Pseudoeunotia doliolus Range-zone of Burckle (1972). Nitzschia reinholdii ranges into the lowermost part of this zone. Its extinction in the North Pacific has been dated as 0.70 m.y. by Kanaya and Koizumi (1970).

Absolute age: 0.26 to 0.92 m.y. (Donahue, 1970). This differs from the interpretation of Kanaya and Koizumi (1970) who estimate the extinction of Rhizosolenia curvirostris as 0.25 m.y. and the extinction of Actinocyclus oculatus as 0.75 m.y.

Geographical extent: Found in North Pacific sediments. Subzones were found only in temperate Pacific sediments (representing floral assemblages of transitional biofacies).

Type locality: DSDP Leg 18, Site 173, Sample $2-3(38-39 \mathrm{~cm})$ to Sample $4-2(55-56 \mathrm{~cm})$.

\section{North Pacific Diatom Zone III}

Definition: The base of this zone is defined at the extinction of Nitzschia fossilis and the disappearance occurrence (not an extinction, see NPD Zones I and II) 
of Actinocyclus ochotensis; the top at the last occurrence of Actinocyclus oculatus.

Discussion: Actinocyclus ochotensis disappears within the middle Pleistocene at the base of this zone. A modern flora in this zone includes Actinocyclus curvatulus, A. oculatus, Coscinodiscus marginatus, C. radiatus (temperate element), Denticula seminae, Hemidiscus cuneiformis (temperate element), Nitzschia marina and Nitzschia reinholdii (temperate element), Rhizosolenia curvirostris, $R$. hebetata forma hiemalis, $R$. styliformis, Stephanopyxis dimorpha (temperate element), St. californica (temperate element), Thalassionema nitzschioides, Thalassiosira decipiens, T. excentrica, T. pacifica, Thalassiothrix longissima, and Biddulphia aurita. Thalassiosira nidulus species ranges well into the Pleistocene in material studied here, in disagreement with its pre-Pleistocene extinction found by Kanaya and Koizumi (1970).

Subzones: The zone can be divided into two subzones. The lower subzone, $B$, is characterized by the occurrence of Thalassiosira nidulus, the upper, $A$, by the absence of Thalassiosira nidulus.

Paleomagnetic stratigraphy: The zone ranges from the middle part of the Matuyama Reversed epoch to the Jaramillo event of the Matuyama Reversed epoch.

Comparison with zonations of other workers: Zone III correlates in part with the Actinocyclus oculatus Zone of Donahue (1970), with Horizon VI and Late Pliocene of Jousé (1971), with the Pseudoeunotia doliolus Range Zone of Burckle (1972), and with the upper part of the Eucyrtidium matayamai radiolarian zone of Hays (1970).

Absolute age: 0.92 to $1.3 \mathrm{~m} . \mathrm{y}$. The extinction of Nitzschia fossilis has previously been estimated as 0.26 m.y. by Kanaya and Koizumi (1970) and as 1.85 m.y. (PliocenePleistocene boundary) by Burckle $(1969,1972)$.

Geographical extent: Found in North Pacific sediments. Subzones found in temperate Pacific sediments (representing floral assemblages of transitional biofacies).

Type locality: DSDP Leg 18, Site 173, Sample 4-3(55-56 $\mathrm{cm})$ to Sample 6-3 $(55-56 \mathrm{~cm})$.

\section{North Pacific Diatom Zone IV}

Definition: The base of this zone is defined by the extinction of Thalassiosira antiqua and Rhizosolenia barboi, and the first evolutionary appearance of Rhizosolenia curvirostris; the top is defined by the extinction of Nitzschia fossilis and the disappearance of Actinocyclus ochotensis in the Middle Pleistocene.

Discussion: It is rather difficult to decide whether Rhizosolenia curvirostris or its ancestor, $R h$. barboi, is present in smear slides. Best results were obtained by observation of the 25 to $40 \mu$ fraction. Other floral elements include Actinocyclus curvatulus, A. oculatus, A. ochotensis, Coscinodiscus marginatus, Denticula seminae, Nitzschia fossilis (temperate element), Nitzschia marina and $N$. reinholdii (temperate elements), Rhizosolenia bergonii (temperate element), $R$. curvirostris, $R$. hebetata forma hiemalis, Stephanopyxis dimorpha, St. californica (temperate element), Thalassionema nitz- schioides, Thalassiosira decipiens, T. excentrica, T. nidulus, $T$. oestrupii, $T$. pacifica, Thalassiothrix frauenfeldii, T. longissima, and Biddulphia aurita. Kanaya and Koizumi (1970) estimate an absolute age for the range of Rhizosolenia curvirostris of 0.26 to $1.85 \mathrm{~m} . \mathrm{y}$. If this datum level is correct, the first evolutionary appearance of Rhizosolenia curvirostris should fall near the Pliocene-Pleistocene boundary prior to the base of the Actinocyclus oculatus Zone (Donahue, 1970) which has an age of 2.2 m.y. The range of Pseudoeunotia doliolus at Site 173 indicates that it first evolves at the first evolutionary appearance of Rhizosolenia curvirostris. This is about the same level as the extinction of Thalassiosira antiqua.

Subzones: No subzones have been defined.

Paleomagnetic stratigraphy: This zone ranges from the middle part of the Matuyama Reversed epoch to the top of the Olduvai event within the Matuyama Reversed epoch.

Comparison with zonations of other workers: Zone IV correlates in part with the middle part of the Actinocyclus oculatus Zone of Donahue (1970), with the lower part of the Pseudoeunotia doliolus Range-zone of Burckle (1972), with the Late Pliocene of Jousé (1971), and with the lower part of the Eucyrtidium matayamai radiolarian zone of Hays (1970).

Absolute age: 1.3 to 1.85 m.y.(?).

Geographical extent: Found in North Pacific sediments.

Type locality: DSDP Leg 18, Site 173, Sample 7-1(67-68 $\mathrm{cm})$ to Sample 8-2 $(55-56 \mathrm{~cm})$.

\section{North Pacific Diatom Zone V}

Definition: The base of this zone is defined by the extinction of Nitzschia californica and the first occurrence of Thalassiosira gravida; the top is defined by the extinctions of Thalassiosira antiqua and Rhizosolenia barboi and the first evolutionary appearance of Rhizosolenia curvirostris.

Discussion: Other floral elements include Actinocyclus curvatulus, A. ochotensis, A. oculatus, Coscinodiscus marginatus, $C$. radiatus (temperate element), Denticula seminae, D. seminae forma fossilis, Hemidiscus cuneiformis (temperate element), Nitzschia californica, $N$. fossilis, $N$. marina, $N$. reinholdii (all temperate elements), Rhizosolenia barboi, $R$. bergonii (temperate element), $R$. hebetata forma hiemalis, Stephanopyxis dimorpha, $S$. californica, Thalassionema nitzschioides, Thalassiosira antiqua, T. excentrica, $T$. gravida, $T$. nidulus, $T$. oestrupii, Thalassiothrix frauenfeldii, $T$. longissima, and Biddulphia aurita. Kanaya and Koizumi (1970) give the following ranges: Thalassiosira gravida, Recent to Middle Miocene (definitely not); Rhizosolenia curvirostris, Recent to 1.85 m.y.; Actinocyclus oculatus, 0.75 to 2.55 m.y.; Thalassiosira antiqua, 2.55 m.y. to Middle Miocene (definitely not). Jousé's zonation (1971), based upon data derived from Lamont-Doherty Geological Observatory Core Vema $20-119$, is not used here because of questionable paleomagnetic stratigraphy in the lower part of the core with part of the section missing (Burckle, 1972 personal communication). 
Subzones: No subzones have been defined.

Paleomagnetic stratigraphy: The top of the zone falls within the Olduvai event of the Matuyama Reversed epoch; the base has not been correlated but probably is younger than the lower part of the Matuyama Reversed epoch.

Comparison with zonations of other workers: Zone V correlates with the lower part of the Actinocyclus oculatus Zone of Donahue (1970), with the upper part of the Rhizosolenia praebergonit Partial Range-zone of Burckle (1972), with the lower part of the Eucyrtidium matayamai radiolarian zone of Hays (1970), and with the Pterocanium prismaticum radiolarian zone of Riedel and Sanfilippo (1971).

Absolute age: The top correlates with the PliocenePleistocene boundary with an age of 1.85 m.y.; the base has not been correlated with previously dated levels.

Geographical extent: Found in North Pacific sediments.

Type locality: DSDP Leg 18, Site 173, Sample 8-3(55-56 $\mathrm{cm}$ ) to Sample $9-4(55-56 \mathrm{~cm})$.

\section{North Pacific Diatom Zone VI}

Definition: The base of this zone is defined at the extinction of Denticula kamtschatica and the first occurrence of Raphoneis cocconeides (found only in temperate waters); the top at the extinction of Nitzschia californica and the first occurrence of Thalassiosira gravida.

Discussion: Associated species include Actinocyclus oculatus, A. ochotènsis, Denticula seminae, D. seminae forma fossilis, Hemidiscus cuneiformis (temperate element), Nitzschia californica, $N$. fossilis, $N$. marina, $N$. reinholdii (all temperate elements), Raphoneis angustata, Rhizosolenia barboi, $R$. styliformis, Stephanopyxis dimorpha, St. turris, Thalassionema nitzschioides, Thalassiosira antiqua, $T$. decipiens, $T$. excentrica, $T$. gravida (upper part of the Zone), $T$. nidulus, $T$. oestrupii, Thalassiothrix frauenfeldii, T. longissima, and Biddulphia aurita. Rhizosolenia praebergonii and Thalassiosira convexa occurred in trace abundances. Kanaya and Koizumi (1970) report a range from Middle Miocene (definitely not) to $2.5 \mathrm{~m} . \mathrm{y}$. for Denticula kamtschatica in North Pacific sediments.

Subzones: No subzones have been defined.

Paleomagnetic stratigraphy: No correlations with paleomagnetic stratigraphy have been made.

Comparison with zonations of other workers: Zone VI correlates with the lower part of the Actinocyclus oculatus Zone of Donahue (1970), with the upper part of the Rhizosolenia praebergonii Partial-range-zone of Burckle (1972), and with the lower part of the Eucyrtidium matayamai radiolarian zone of Hays (1970).

Absolute age: Accurate estimates of exact age could not be made. An approximate age, based on sedimentation rates and comparison with the zonation of other workers, is 1.85 to 2.2 m.y.

Geographical extent: Found in North Pacific sediments.

Type locality: DSDP Leg 18, Site 173, Sample 9-5(55-56 $\mathrm{cm})$ to Sample $10-5(55-56 \mathrm{~cm})$.

\section{North Pacific Diatom Zone VII}

Definition: The base of this zone is defined by the extinction of Nitzschia jouseae, the first occurrence of Thalassiosira nidulus, and the first appearance of Stephanopyxis dimorpha. The top is defined by the extinction of Denticula kamtschatica and the first appearance of Rhaphoneis cocconeides (found only in temperate waters).

Discussion: Nitzschia jouseae ranges in equatorial Pacific sediments from the middle part of the Gilbert Reversed epoch ("c" event) to the top of the Gauss Normal epoch. Accordingly, the base of this zone is probably not younger than 2.5 m.y. Kanaya and Koizumi (1970) report the extinction of Denticula kamtschatica at the top of the Gauss Normal epoch. Jousé (1971) found Denticula kamtschatica in Lamont-Doherty Geological Observatory Core Vema 20-119, 11.05 meters below the surface. The paleomagnetic stratigraphy of the lower part of this core is problematic and may represent the top of the Gauss Normal epoch rather than the Olduvai event. Other floral elements include Actinocyclus ochotensis, A. oculatus, Asteromphalus robustus, Coscinodiscus marginatus, Denticula kamtschatica, D. seminae, D. seminae forma fossilis, Hemidiscus cuneiformis (temperate element), Nitzschia californica, $N$. fossilis, $N$. marina, $N$. reinholdii (all temperate elements), Rhizosolenia barboi, $R$. hebetata forma hiemalis, Stephanopyxis dimorpha, S. turris, S. californica, Thalassionema nitzschioides, Thalassiosira antiqua, $T$. decipiens, $T$. excentrica, T. nidulus, T. oestrupii, Thalassiothrix longissima, Coscinodiscus nodulifer (temperate element), and Biddulphia aurita.

Subzones: No subzones have been defined.

Paleomagnetic stratigraphy: The top of Zone VII has not been correlated with paleomagnetic events; the base correlates with the top of the Gauss Normal epoch.

Comparison with zonations of other workers: Correlates in part with the upper Pliocene of Kurilsk and Iturup Island (Jousé, 1959), with the lower part of the Actinocyclus oculatus Zone of Donahue (1970), with the upper part of the Rhizosolenia praebergonii Partialrange-zone of Burckle (1972), with the Oga Diatom Zone 7 of Koizumi (1968), and with the Spongaster pentas radiolarian zone of Riedel and Sanfilippo (1971).

Absolute age: The top of this zone, according to correlation with the lower part of the Actinocyclus oculatus Zone of Donahue (1970), is 2.2 m.y. old. The base is dated at $2.5 \mathrm{~m} . \mathrm{y}$.

Geographical extent: Found in North Pacific sediments and in land sections from Japan.

Type locality: DSDP Leg 18, Site 173, Sample 10-6(55-56 $\mathrm{cm}$ ) to Sample $12-2(55-56 \mathrm{~cm})$.

\section{North Pacific Diatom Zone VIII}

Definition: The base of this zone is defined by the extinctions of Denticula hyalina, Actinocyclus ellipticus, and Rhizosolenia praealata. The top is defined by the extinction of Nitzschia jouseae and the first appearances of Thalassiosira nidulus and Stephanopyxis dimorpha. 
Discussion: Other floral elements include Actinocyclus ehrenbergii, A. ochotensis, Coscinodiscus marginatus, $C$. nodulifer (temperate element), Denticula kamtschatica, $D$. seminae, D. seminae forma fossilis, Lithodesmium minusculum, Nitzschia fossilis, $N$. jouseae, $N$. marina, $N$. reinholdii (all temperate elements), Raphoneis angustata, Rhizosolenia barboi, $R$. bergonii (temperate element), $R$. hebetata forma hiemalis, $R$. styliformis, Stephanopyxis dimorpha, S. turris, Thalassionema nitzschioides, Thalassiosira antiqua, T. convexa, $T$. excentrica, $T$. oestrupii, and Thalassiothrix longissima. Kanaya and Koizumi (1970) report a range of Actinocyclus ellipticus from Middle Miocene to the lower part of Late Miocene. Here the species ranges well into the Pliocene.

Subzones: No subzones have been defined.

Paleomagnetic stratigraphy: The top of Zone VIII approximates the top of the Gauss Normal epoch, the base probably falls within the upper part of the Gauss Normal epoch.

Comparison with zonations of other workers: This zone correlates in part with the lower part (lacking Thalassiosira nativa) of the Rhizosolenia praebergonii Partialrange-zone of Burckle (1972) and with the Oga Diatom Zone 7 of Koizumi (1968).

Absolute age: The top of this zone is dated at 2.5 m.y.; the base has not been dated.

Geographical extent: Found in North Pacific sediments.

Type locality: DSDP Leg 18, Site 173, Sample 12-3(55-56 $\mathrm{cm})$ to Sample 14-1 $(55-56 \mathrm{~cm})$.

\section{North Pacific Diatom Zone IX}

Definition: The base of this zone is defined by the extinction of Actinocyclus ingens, the first evolutionary appearance of Thalassiosira oestrupii, and the first evolutionary appearance of Denticula seminae. The top is defined by the extinctions of Denticula hyalina, Actinocyclus ellipticus, and Rhizosolenia praealata.

Discussion: At the base of this zone, Denticula seminae evolves from its ancestor Denticula kamtschatica, and Thalassiosira oestrupii from its ancestor Thalassiosira nativa. Other floral elements are Actinocyclus ingens, $A$. ellipticus, A. ochotensis, Coscinodiscus marginatus, $C$. marginatus forma fossilis, Denticula hyalina, D. kamtschatica, Lithodesmium californicum, Nitzschia marina, $N$. fossilis, $N$. jouseae, N. reinholdii, Rhizosolenia barboi, $R$. hebetata forma hiemalis, $R$. styliformis, Stephanopyxis turris, Thalassionema nitzschioides, Thalassiosira antiqua, T. convexa, T. excentrica, T. oestrupii, Thalassiothrix longissima, and Coscinodiscus nodulifer. The extinction of Thalassiosira nativa occurs within the lower part of the Rhizosolenia praebergonii Partialrange-zone of Burckle (1972), approximately in the middle of the Gauss Normal epoch. Denticula seminae ranges from the top of the Gauss Normal epoch to Recent (Kanaya and Koizumi, 1970). Here the species ranges well into the upper part of the Gauss Normal epoch. The systematic position of Denticula hyalina could not be determined from the literature; it may be a synonym of Denticula lauta or Denticula kamtschatica.

Subzones: No subzones have been defined.
Paleomagnetic stratigraphy: Paleomagnetic stratigraphy has not been determined (see discussion above).

Comparison with zonations of other workers: This zone correlates in part with the lower part of the Rhizosolenia praebergonii Partial-range-zone of Burckle (1972), and with the Oga Diatom Zone 7 of Koizumi (1968).

Absolute age: No absolute age has been estimated.

Geographical extent: Found in North Pacific sediments.

Type locality: DSDP Leg 18, Site 173, Sample 14-2(95-96 $\mathrm{cm})$ to Sample 14(CC).

\section{North Pacific Diatom Zone X}

Definition: The base of this zone is defined by the extinctions of Thalassiosira usatchevii, Rhaphoneis sachalinensis, Nitzschia praereinholdii, Nitzschia miocenica, and Lithodesmium minusculum, and the first occurrences of Denticula hyalina, D. kamtschatica, Nitzschia reinholdii, and Nitzschia marina. The top is defined by the extinction of Actinocyclus ingens and the first evolutionary appearances of Thalassiosira oestrupii and Denticula seminae.

Discussion: At the base of this zone, Nitzschia reinholdii evolves from its ancestor, Nitzschia praereinholdii. Other floral elements include Actinocyclus ehrenbergii, $A$. ellipticus, A. ingens, A. ochotensis, Asteromphalus darwinii, Coscinodiscus marginatus, $C$. nodulifer, $C$. radiatus, C. stellaris, C. symbolophorus, Denticula hustedtii, D. hyalina, D. kamtschatica, Hemiaulus c.f. polymorphus, Hemidiscus cuneiformis, Lithodesmium californicum, Nitzschia cylindrica, $N$. fossilis, $N$. jouseae, $N$. marina, $N$. reinholdii, Rhaphoneis angustata, Rhizosolenia barboi, $R$. bergonii, $R$. praealata, $R$. styliformis, Rouxia californica, Stephanopyxis turris, Thalassionema nitzschioides, Thalassiosira antiqua, T. convexa, $T$. excentrica, T. nativa, Thalassiothrix frauenfeldii, $T$. longissima, and Biddulphia aurita. The ranges of indicator species here are different from equatorial and North Pacific sediments. The range of Nitzschia jouseae reaches the level of the first occurrence of Thalassiosira usatchevii, possibly attributable, in part, to differing systematic treatment of the species. In this report, the taxonomic interpretation of Sheshukova-Poretskaya was followed strictly. The same is true for Nitzschia miocenica. Denticula hustedtii has a reported range (Kanaya and Koizumi, 1970) from the Middle Miocene to Late Pliocene. The Late Pliocene extinction does not correspond to the results found here.

Subzones: No subzones have been defined.

Paleomagnetic stratigraphy: Based upon the paleomagnetic stratigraphy of Burckle (1972), the base of this zone (extinction of Thalassiosira usatchevii) falls tentatively within the "c" event of the Gilbert Reversed epoch. The top has not been correlated with paleomagnetic events.

Comparison with zonations of other workers: Zone X correlates in part with the Nitzschia jouseae Partialrange-zone of Burckle (1972), with the Oga Diatom Zones 6 and 7 (?) of Koizumi (1968), and with the Upper-Middle Pliocene of Kurilsk, Iturup Island, eastern Coast of Kamchatka, and southern Sakhalin of Jousé (1959). 
Absolute age: Assuming that the base of this zone falls within the "c" event of the Gilbert Reversed epoch, an age of $4.38 \mathrm{~m} . \mathrm{y}$. can be postulated for the base using Berggren's (1969) time scale.

Geographical extent: Found in North Pacific sediments and in land sections from Japan and Kamchatka.

Type locality: DSDP Leg 18, Site 173 Sample 15-2(55-56 $\mathrm{cm}$ ) to Sample $15(\mathrm{CC})$.

\section{North Pacific Diatom Zone XI}

Definition: The base of this zone is defined by the extinction of Nitzschia rolandii, and the first occurrences of Nitzschia fossilis, Nitzschia jouseae, Thalassiosira convexa, Thalassiosira antiqua and Actinocyclus ochotensis. The top is defined by the extinctions of Thalassiosira usatchevii, Rhaphoneis sachalinensis, Nitzschia praereinholdii, Nitzschia miocenica, and Lithodesmium minusculum, and the first occurrences of Denticula hyalina Denticula kamtschatica, Nitzschia reinholdii, and Nitzschia marina.

Discussion: Other floral elements include Actinocyclus ellipticus, A. ingens, A. ochotensis, Asteromphalus robustus, A. darwinii, Bruniopsis mirabilis, Coscinodiscus marginatus, Coscinodiscus marginatus forma fossilis, $C$. miocenicus, $C$. nodulifer, $C$. radiatus, $C$. stellaris, C. symbolophorus, Denticula hustedtii, Hemiaulus c.f. polymorphus, Lithodesmium californicum, L. minusculum, Mediaria splendida forma tenera, Nitzschia cylindrica, $N$. fossilis, $N$. miocenica, $N$. praereinholdii, Rhizosolenia bergonii, $R$. praealata, Rouxia californica, Stephanopyxis turris, Thalassionema nitzschioides, $T$. stomachii, Thalassiosira antiqua, $T$. convexa, $T$. excentrica, $T$. nativa, $T$. usatchevii, Thalassiotrix longissima, Coscinodiscus vetustissimus. The range of Thalassiosira nativa is different from equatorial Pacific sediments. The top of this zone has been defined as the Pliocene-Miocene boundary (Burckle, 1972). This is in good agreement with the ranges of several taxa given by Kanaya and Koizumi (1970): the extinctions of Thalassiosira antiqua, Rouxia californica and Mediaria splendida.

Subzones: No subzones have been defined.

Paleomagnetic stratigraphy: The base of this zone has been correlated with the top of magnetic epoch 5 , the top falls within the "c" event of the Gilbert Reversed epoch.

Comparison with zonations of other workers: Zone XI correlates in part with the Middle Pliocene of Jouse (1959), with the upper part of the Thalassiosira convexa Partial-range-zone of Burckle (1972), with the upper part of the N.18 foraminiferal zone of Blow (1969), and with the upper part of the Stichocorys peregrina radiolarian zone of Riedel and Sanfilippo (1971).

Absolute age: This zone has a tentative absolute age of 4.3 to 5.5 m.y using Berggren's time scale (1969).

Geographical extent: Found in equatorial and North Pacific sediments.

Type locality: DSDP Leg 18, Site 173, Sample 16-1(69-70 $\mathrm{cm})$ to Sample $15-2(55-56 \mathrm{~cm})$

North Pacific Diatom Zone XII
Definition: The base of this zone is defined by the extinctions of Thalassiosira praeconvexa and Nitzschia praefossilis; the top by the extinction of Nitzschia rolandii and the first appearances of Nitzschia jouseae, Thalassiosira convexa Thalassiosira antiqua, Nitzschia fossilis and Actinocyclus ochotensis.

Discussion: Other floral elements are comparable with those found in NPD Zone XI. Burckle (1972) placed the extinction of Thalassisira praeconvexa at the base of the "a" event of the magnetic normal epoch 5. Thalassiosira nativa is still present.

Subzones: No subzones have been defined.

Paleomagnetic stratigraphy: The base of this zone has not been correlated with paleomagnetic events; the top occurs within the top of the magnetic normal epoch 5 .

Comparison with zonations of other workers: Zone XII correlates in part with the Thalassiosira convexa Partialrange-zone of Burckle (1972), and with the Stichocorys peregrina radiolarian zone of Riedel and Sanfilippo (1971).

Absolute age: The top of this zone has an extrapolated age of 5.5 m.y. using Berggren's (1969) time scale; the age of the base has not been estimated.

Geographical extent: Found in equatorial and North Pacific sediments.

Type locality: DSDP Leg 18, Site 173, Sample 17-3(55-56 $\mathrm{cm})$ to Sample 17(CC).

\section{North Pacific Diatom Zone XIII}

Definition: The base of this zone is defined by the extinction of Coscinodiscus temperei and the first appearance of Coscinodiscus c.f. lacustris; the top by the extinctions of Thalassiosira praeconvexa and Nitzschia praefossilis.

Discussion: Other floral elements include Actinocyclus ellipticus $A$. ingens, Coscinodiscus marginatus, $C$. marginatus forma fossilis, $C$. radiatus, $C$. stellaris, $C$. symbolophorus, Denticula hustedtii, Hemiaulus c.f. polymorphous, Hemidiscus cuneiformis, Lithodesmium californicum, L. minusculum, Mediaria splendida, Nitzschia cylindrica, $N$. praefossilis, $N$. miocenica, $N$. porteri (last occurrence in lower part of this zone), $N$. praereinholdii, Rhaphoneis schalinensis, Rhizosolenia barboi, $R$. praealata, $R$. styliformis, Rouxia californica, Stephanopyxis turris Thalassionema nitzschioides, Thalassiosira excentrica, $T$. nativa, $T$. praeconvexa, Thalassiotrix longissima, Coscinodiscus vetustissimus, and Biddulphia aurita. Rhizosolenia miocenica, Coscinodiscus endoi and Cladogramma dubium have their extinction and Nitzschia cylindrica its first appearance near the top of this zone. A chart by Koizumi (1968) shows Coscinodiscus temperei in almost all samples of his Oga Diatom Zones 1 through 7 (see his diatom Chart 2), while another chart (Chart 1) indicates that Coscinodiscus temperei is found only in Oga Diatom Zones 1 through 5 . The latter range would be in better agreement with the range found here. Nevertheless, Koizumi does not indicate the amount of reworking in his material. Kanaya and Koizumi (1970) show evidence that the extinction of Coscinodiscus endoi occurs within the Middle Miocene, whereas Koizumi (1968) found it 
only in his Diatom Zone 1. The extinction level of Coscinodiscus temperei occurs within the Schmidt Peninsula diatom sequence, North Sakhalin, and in the diatom suite of the west coast of Kamchatka, according to Jousé (1959). Jousé placed her Lower to Middle Pliocene boundary at the extinction level of Coscinodiscus temperei and Rouxia californica.

Subzones: No subzones have been defined.

Plaeomagnetic stratigraphy: The base of this zone probably falls within the middle part of the magnetic reversed epoch 6 . The top has not been correlated with paleomagnetic stratigraphy.

Comparison with zonations of other workers: Zone XIII correlates in part with the middle Pliocene of Jouse (1959), with the Nitzschia miocenica Partial-range-zone of Burckle (1972), with the lower part of the Stichocorys peregrina radiolarian zone of Riedel and Sanfilippo (1971).

Absolute age: The base of this zone occurs within the middle part of the magnetic reversed epoch 6 , with an age of about 6.5 to $7 \mathrm{~m} . \mathrm{y}$. according to Berggren's (1969) time scale. The top has not been dated.

Geographical extent: Found in equatorial and North Pacific sediments and in land sections from Japan, Kamchatka, and California.

Type locality: DSDP Leg 18, Site 173, Sample 18-2(55-56 $\mathrm{cm})$ to Sample $18-4(56-57 \mathrm{~cm})$.

\section{North Pacific Diatom Zone XIV}

Definition: The base of this zone is defined by the extinction of Hemidiscus simplicissimus Denticula punctata, Denticula lauta, and Denticula dimorpha, and at the first appearance of Rhaphoneis sachalinensis. The top is defined by the extinction of Coscinodiscus temperei and at the first appearance of Coscinodiscus c.f. lacustris. The extinction of Nitzschia porteri occurs just above the top of this zone.

Discussion: Other floral elements include Actinocyclus ellipticus. A. ingens, Cladogramma dubium, Coscinodiscus endoi, $C$. flexuosus, $C$. c.f. lacustris, $C$. marginatus $C$. marginatus forma fossilis, $C$. radiatus, $C$. symbolophorus, C. stellaris, C. temperei, Denticula hustedtii, Hemiaulus c.f. polymorphus, Hemidiscus cuneiformis, Lithodesmium californicum, L. minusculum, Nitzschia praefossilis, N. miocenica, N. porteri, $N$. praereinholdii, $N$. rolandii, Rhaphoneis sachalinensis, Rhizosolenia barboi, $R$. miocenica, $R$. praealata, $R$. styliformis, Rouxia californica, Thalassionema nitzschioides, Thalassiosira excentrica, T. nativa, T. praeconvexa, Thalassiothrix longissima, Coscinodiscus vetustissimus. Nitzschia miocenica is still present as is Thalassiosira praeconvexa and Thalassiosira nativa. Coscinodiscus endoi is only present in Oga Diatom Zones 1 and 2 (Koizumi, 1968). The extinction of Denticula lauta has not been defined by Kanaya and Koizumi (1970).

Subzones: No subzones have been defined.

Paleomagnetic stratigraphy: The base of this zone probably falls within the "a" event of magnetic epoch 7 according to Burckle's (1972) placement of the extinction of Nitzschia porteri in this event. The top falls within the middle part of the magnetic reversed epoch 6.

Comparison with zonations of other workers: Zone XIV correlates in part with the lower Pliocene of Jouse (1959), with the lower part of the Nitzschia miocenica Partial-range-zone of Burckle (1972), with the Oga Diatom Zone 2 of Koizumi (1968), and with the Ommatartus penultimus radiolarian zone of Riedel and Sanfilippo (1971).

Absolute age: The base of this zone occurs within the "a" event of the magnetic reversed epoch 7 which suggests an age of about 7.3. m.y. The extrapolated age of the top is about 6.8 m.y. according to Berggren's (1969) time scale.

Geographical extent: Found in equatorial and North Pacific sediments and in land sections from Japan, Kamchatka, and California.

Type locality: DSDP Leg 18, Site 173, Sample 18-5(55-56 $\mathrm{cm})$ to Sample $19-2(55-56 \mathrm{~cm})$.

\section{North Pacific Diatom Zone XV}

Definition: The base of this zone is defined by the first appearances of Nitzschia praereinholdii, Nitzschia miocenica, Rhizosolenia praealata, and Lithodesmium minusculum; the top by the extinctions of Hemidiscus simplicissimus, Denticula punctata, Denticula lauta and Denticula dimorpha, and at the first appearance of Rhaphoneis sachalinensis.

Discussion: Other floral elements include Actinocyclus ellipticus, $A$. ingens, Coscinodiscus endoi, C. flexuosus, C. marginatus, C. marginatus forma fossilis, C. stellaris, C. symbolophorus, Denticula dimorpha, $D$. hustedtii, $D$. lauta, D. punctata, Hemiaulus polymorphus, Hemidiscus cuneiformis, $H$. simplicissimus, Lithodesmium californicum, L. minusculum, Nitzschia porteri, N. rolandii, Rhizosolenia barboi, $R$. miocenica, $R$. styliformis, Rouxia californica, Thalassionema nitzschioides, Thalssiosira excentrica, T. nativa, T. praeconvexa, Thalassiothrix longissima, and Coscinodiscus vetustissimus. Ranges of Thalassiosira praeconvexa and Thalassiosira nativa are longer here than those reported by Burckle (1972), possibly because of differing systematic interpretations, here, Thalassiosira nativa is synonymized with Thalassiosira spec. A of Burckle (1972).

Subzones: No subzones have been defined.

Paleomagnetic stratigraphy: The base of this zone occurs within the "b" event of the magnetic normal epoch 7 according to Burckle's (1972) placement of the first evolutionary appearance of Nitzschia miocenica; the top occurs within the "a" event of the magnetic normal epoch 7.

Comparison with zonations of other workers: Zone XV correlates in part with the Oga Diatom Zone 2 of Koizumi (1968), with the lower Pliocene of Jouse (1959), with the lower part of the Nitzschia miocenica Partial-range-zone of Burckle (1972), and with the Ommatartus penultimus radiolarian zone of Riedel and Sanfilippo (1971). 
Absolute age: The base of this zone probably has an approximate age of $7.5 \mathrm{~m} . \mathrm{y}$.; the top an age of approximately 7.3 m.y. using Berggren's (1969) time scale.

Geographical extent. Found in equatorial and North Pacific sediments and in land sections from Japan, Kamchatka, and California.

Type locality: DSDP Leg 18, Site 173, Sample 19-4(55-56 $\mathrm{cm})$ to Sample $20-2(55-56 \mathrm{~cm})$.

\section{North Pacific Diatom Zone XVI}

Definition: The base of this zone is defined by the extinctions of Coscinodiscus paleaceus, Coscinodiscus yabei, Rhizosolenia praebarboi, Denticula punctata forma hustedtii, and Coscinodiscus plicatus, and by the first appearances of Thalassiosira praeconvexa, Rhaphoneis angustata, and Rhizosolenia barboi. The top is defined by the first appearances of Nitzschia praereinholdii, Nitzschia miocenica, Rhizosolenia praealata, and Lithodesmium minusculum.

Discussion: Other floral elements include Actinocyclus ehrenbergii, A. ellipticus, A. ingens, Asterolampra marylandica, Coscinodiscus endoi, $C$. flexuosus, $C$. marginatus, C. marginatus forma fossilis, $C$. praepaleaceus, $C$. plicatus, $C$. radiatus, $C$. stellaris, $C$. symbolophorus, C. temperei, Denticula dimorpha, D. hustedtii, D. lauta, D. punctata forma hustedtii, Hemiaulus c.f. polymorphus, Hemidiscus cuneiformis, H. simplicissimus, Lithodesmium californicum, Nitzschia porteri, $N$. rolandii, Rhizosolenia barboi, $R$. praebarboi (lower part of the Zone), $R$. styliformis, Rouxia californica, Thalassiosira excentrica, $T$. nativa (first appearance upper part of the zone), $T$. praeconvexa, (first appearance upper part of the zone), Thalassiothrix longissima, Triceratium condecorum, Coscinodiscus vetustissimus, and Biddulphia aurita.

Subzones: No subzones have been defined.

Paleomagnetic stratigraphy: The top of NPD Zone XVI occurs within the "b" event of magnetic normal epoch 7 , the base within the middle part of magnetic epoch 8 (Burckle, 1972).

Comparison with zonations of other workers: Zone XVI correlates in part with the lower part of the Nitzschia porteri Range-zone of Burckle (1972), with the Upper Miocene of Jousé (1959) of South Sakhalin, Pozharskoye, Lapatino, and with the lower two thirds of the Ommatartus penultimus radiolarian zone of Riedel and Sanfilippo (1971).

Absolute age: An approximate absolute age for the top of this zone 7.5 m.y., and 8.2 m.y. for the base, can be postulated from paleomagnetic stratigraphy using Berggren's time scale (1969).

Type locality: DSDP Leg 18, Site 173, Sample $203(55-56$ $\mathrm{cm})$ to Sample 21-1(99-100 cm).

\section{North Pacific Diatom Zone XVII}

Definition: The base of this zone is defined by the first occurrence of Hemidiscus simplicissimus and Coscinodiscus temperei; the top by the extinctions of Mediaria splendida, Coscinodiscus paleaceus, Coscinodiscus yabei, Rhizosolenia praebarboi, Denticula punctata forma hustedtii, Coscinodiscus plicatus and the first occurrences of Thalassiosira praeconvexa, Rhaphoneis angustata, and Rhizosolenia barboi.

Discussion: Other floral elements include Actinocyclus ehrenbergii, A. ellipticus, A. ingens, Bruniopsis mirabilis, Cladogramma dubium, Coscinodiscus endoi, C. flexuosus, C. yabei, C. marginatus, C. marginatus forma fossilis, $C$. miocenicus, $C$. nodulifer, $C$. paleaceus, $C$. praepaleaceus, C. plicatus, C. stellaris, C. symbolophorus, C. temperei, Craspedodiscus coscinodiscus, Denticula dimorpha, D. hustedtii, D. lauta, D. punctata, D. punctata forma hustedtii, Hemiaulus c.f. polymorphus, Hemidiscus simplicissimus, Lithodesmium californicum, Mediaria splendida, Nitzschia porteri, $N$. rolandii, Rhizosolenia hebetata forma hiemalis, $R$. miocenica, $R$. praebarboi, $R$. styliformis, Rouxia californica, Stephanopyxis turris, Synedra jouseana, Thalassionema claviformis, T. nitzschioides, Thalassiothrix longissima, Triceratium condecorum, and Coscinodiscus vetustissimus. Ranges of taxa determined by Kanaya and Koizumi (1970) are Mediaria spendida, lower part of the Middle Miocene to the upper part of the Middle Miocene, and Coscinodiscus yabei, lower part of the Middle Miocene to the upper part of the Middle Miocene (partly to the lower part of the Upper Miocene). Ranges reported by Burckle (1971) are Nitzschia porteri, from lower part of magnetic epoch 11 to "b" event of magnetic epoch 7; Coscinodiscus paleaceus, from the Globorotalia fohsi peripheroacuta Zone of Blow (1969) to the top of the Nitzschia porteri Partial-range-zone; and Coscinodiscus yabei, from the Globorotalia fohsi peripheroacuta Zone to the middle part of magnetic epoch 8 .

Subzones: No subzones have been defined.

Paleomagnetic stratigraphy: The top of this zone occurs within the middle part of magnetic epoch 8 (extinction of Coscinodiscus yabei); the base has not been correlated with paleomagnetic events.

Comparison with zonations of other workers: Zone XVII correlates in part with the upper part of the Coscinodiscus yabei Partial-range-zone of Burckle(1972), with the Diatom Zone II of Kanaya (1971), with the Oga Diatom Zones 1 and 2 of Koizumi (1968), and with the Ommatartus antepenultimus radiolarian zone of Riedel and Sanfilippo (1971).

Absolute age: An absolute age for the extinction level of Coscinodiscus yabei of 8.2 m.y. can be postulated using Berggren's (1969) time scale; the base has not been dated.

Geographical extent: Found in equatorial and North Pacific sediments and in land sections from Japan and California.

Type locality: DSDP Leg 18, Site 173, Sample 21-3(55-56 $\mathrm{cm})$ to Sample $22-2(55-56 \mathrm{~cm})$.

\section{North Pacific Diatom Zone XVIII}

Definition: The base of this zone is defined by the extinctions of Rouxia naviculoides and Denticula nicobarica, and the first appearances of Denticula punctata forma hustedtii and Denticula dimorpha. The 
top is defined by the first appearances of Hemidiscus simplicissimus and Coscinodiscus temperei.

Discussion: Other floral elements include Actinocyclus ehrenbergii, A. ellipticus, A. ingens, Asterolampra marylandica, Bruniopsis mirabilis, Coscinodiscus endoi, C. flexuosus, C. yabei, C. marginatus, C. marginatus forma fossilis, $C$. nodulifer, $C$. paleaceus, $C$. praepaleaceus, C. plicatus, C. stellaris, Denticula dimorpha, D. hustedtii D. Lauta, D. punctata, D. punctata forma hustedtii, Hemiaulus c.f. polymorphus, Mediaria splendida, Nitzschia porteri, N. rolandii, Rhizosolenia miocenica, $R$. praebarboi, $R$. styliformis, Rouxia californica, Stephanopyxis turris, Synedra jouseana, Thalassionema nitzschioides, Thalassiothrix longissima, and Coscinodiscus vetustissimus. This zone correlates with the Diatom Zone II of Kanaya (1971) because of the presence of Actinocyclus ellipticus and Bruniopsis mirabilis. Denticula nicobarica ranges in the Experimental Mohole from the base to approximately 100 meters below the top. This longer range found by Kanaya (1971) may be due to the fact that Denticula nicobarica and Denticula punctata were treated as synonyms. Nitzschia porteri is still present and was found first within the lower half of magnetic epoch 11 in equatorial sediments by Burckle (1972).

Subzones: No subzones have been defined.

Paleomagnetic stratigraphy: No correlations with paleomagnetic stratigraphy have been made.

Comparison with zonations of other workers: Zone XVIII correlates in part with the Coscinodiscus yabei Partial-range-zone of Burckle (1972), with the Diatom Zone II of Kanaya (1971), with the Oga Diatom Zones 1 and 2 of Koizumi (1968), with the Coscinodiscus yabei Assemblage of Kanaya (1959), and with the Ommatartus antepenultimus and Cannartus petterssonii radiolarian zones of Riedel and Sanfilippo (1971).

Absolute age: No absolute age determinations have been made.

Geographical extent: Found in equatorial and North Pacific sediments and in land sections from Japan and California.

Type locality: DSDP Leg 18, Site 173, Sample 22-3(55-56 $\mathrm{cm})$ to Sample $23-1(110-111 \mathrm{~cm})$.

\section{North Pacific Diatom Zone XIX}

Definition: The base of this zone is defined by the first evolutionary appearances of Coscinodiscus plicatus and Nitzschia rolandii, the first occurrences of Actinocyclus ellipticus and Coscinodiscus paleaceus and the extinction of Nitzschia challengeri. The top is defined by the extinction of Rouxia naviculoides and Denticula nicobarica, and the first appearances of Denticula punctata forma hustedtii and Denticula dimorpha.

Discussion: Other floral elements include Actinocyclus ehrenbergii, A. ellipticus, A. ingens, Bruniopsis mirabilis, Cladogramma dubium, Coscinodiscus endoi, C. yabei, $C$. marginatus, $C$. marginatus forma fossilis, $C$. paleaceus, $C$. praepaleaceus, C. plicatus, C. radiatus, C. symbolophorus, Denticula hustedtii, D. lauta, D. nicobarica, Hemiaulus polymorphus, Mediaria splendida, Nitzschia porteri, $N$. rolandii, Rhizosolenia miocenica, $R$. prae- barboi, $R$. styliformis, Rouxia californica, R. naviculoides, Stephanopyxis turris Synedra jouseana Thalassionema nitzschioides, Thalassiothrix longissima, Triceratium cinnamomeum, $T$. condecorum, and CoscinoGloborotalia bykovae Zone (Saito, 1963) and is of discus paleaceus and Actinocyclus ellipticus have been found to occur in the Experimental Mohole (Kanaya, 1971) at about 132 meters below the top. This level has an absolute age of about 12.0 m.y. (Dymond, 1966), which would be correlative with the "a" event of magnetic epoch 11 using Berggren's (1969) time scale. Kanaya and Koizumi (1970) correlate the range of Actinocyclus ellipticus with the planktonic foraminiferal zones N.10 to N.16 of Blow (1969). Their correlation with the foraminiferal datum planes of Berggren (1969) is incorrect. The base of the boundary between Late and Middle Miocene has been defined by Berggren at the base of the Foraminiferal Standard Zone N.13 and not in the middle of $\mathrm{N} .15$ as indicated by Kanaya and Koizumi, 1970.

Subzones: No subzones have been defined.

Paleomagnetic stratigraphy: The base of this zone apparently occurs within the "a" event of magnetic epoch 11 ; the top has not been correlated with paleomagnetic events.

Comparison with zonations of other workers: Zone XIX is correlated in part with the lower part of the Coscinodiscus yabei Partial-range-zone of Burckle (1972), with the lower part of Diatom Zone II of Kanaya (1971), with the Oga Diatom Zone 1 of Koizumi (1968), with the Coscinodiscus yabei Assemblage of Kanaya (1959), with the upper part of the Cannartus laticonus radiolarian zone of Riedel and Sanfilippo (1971), and with the upper part of the Corbisema triacantha silicoflagellate zone of Martini (1971).

Absolute age: An extrapolated absolute age for the base of this zone is 12.0 m.y.; the top has not been dated.

Geographical extent: Found in North Pacific sediments and in land sections from Japan and California.

Type locality: DSDP Leg 18, Site 173, Sample 23-2(55-56 $\mathrm{cm})$ to Sample $24(\mathrm{CC})$.

\section{North Pacific Diatom Zone XX}

Definition: The base of this zone is defined by the last occurrence of Coscinodiscus lewisianus and the first occurrence of Coscinodiscus praepaleaceus. The top is defined by the first evolutionary appearance of Coscinodiscus plicatus; the first occurrences of Nitzschia rolandii, Actinocyclus ellipticus, and Coscinodiscus paleaceus; and the extinctions of Nitzschia challengeri and Coscinodiscus praeyabei.

Discussion: Other floral elements include Actinocyclus ingens, Bruniopsis mirabilis, Coscinodiscus endoi, $C$. yabei, C. praeyabei, C. marginatus, C. marginatus forma fossilis, C. praepaleaceus, C. symbolophorus, Denticula hustedtii, $D$. hyalina, $D$. lauta, $D$. nicobarica, $D$. punctata, Hemiaulus c.f. polymorphus, Mediaria splendida, Nitzschia challengeri, N. porteri, Rhizosolenia miocenica, $R$. praebarboi, $R$. styliformis, Rouxia naviculoides, Stephanopyxis turris, Synedra jouseana, 
Thalassionema nitzschioides, Thalassiothrix longissima, T. miocenica, and Coscinodiscus vetustissimus. Bruniopsis mirabilis has a longer range than that found in the Experimental Mohole by Kanaya (1971). Coscinodiscus lewisianus had its last occurrence in the Experimental Mohole at about 160 meters below the top but with abundances of 5.5 to 9.9 percent of the total assemblage. This high abundance means that the extinction should be placed somewhere between 160 and 135 meters. Kanaya correlated the boundary of the Luisian to Lower Mohnian stages of California with the boundary of his Diatom Zones I and II at about 145 meters below the top. This level has an extrapolated age of 13.5 m.y. using Dymond's (1966) potassium-argon geochronology for the Experimental Mohole with a postulated sedimentation rate of $1.1 \mathrm{~cm} / 10^{3} \mathrm{y}$. This same level has been placed in the NN6 calcareous nannoplankton zone by Martini (personal communication 1972) which correlates with the plankton foraminiferal zones N.12 to N.11 of Blow (1969) and in part with the Dorcadospyris alata radiolarian zone of Riedel and Sanfilippo (1971) (Martini, 1971). Nitzschia porteri is still present in this zone. Burckle (1972) found its first occurrence in equatorial Pacific sediments in the magnetic epoch 11. The differences in the ranges of Coscinodiscus yabei and Coscinodiscus plicatus (see Kanaya, 1971; Burckle, 1972) may be caused by different systematic interpretation of the species. Other plicate species of Coscinodiscus range well into the Middle Miocene and are included in Coscinodiscus yabei by other authors.

Subzones: No subzones have been defined.

Paleomagnetic stratigraphy: No correlations with paleomagnetic stratigraphy have been made.

Comparison with zonations of other workers: Zone XX correlates in part with the lowest part of the Coscinodiscus yabei Partial-range-zone of Burckle (1972) with the lowest part of the Diatom Zone II of Kanaya (1971), with the upper part of NN6 calcareous nannofossil zone of Martini (1971), with the upper part of the Corbisema triacantha silicoflagellate zone of Martini (1971), and with the Dorcadospyris alata radiolarian zone of Riedel and Sanfilippo (1971).

Absolute age: The base of this zone has an extrapolated age of 13.5 m.y., the top an extrapolated age of 12.0 m.y.

Geographical extent: Found in North Pacific sediments.

Type locality: DSDP Leg 18, Site 173, Sample 25-1(95-96 $\mathrm{cm}$ ) to Sample 25(CC).

\section{North Pacific Diatom Zone XXI}

Definition: The base of this zone is defined by the first appearances of Nitzschia challengeri, Coscinodiscus yabei, and Cladogramma dubium; the top by the last occurrence of Coscinodiscus lewisianus and the first appearance of Coscinodiscus praepaleaceus.

Discussion: Other floral elements include Actinocyclus ingens, Bruniopsis mirabilis, Cladogramma dubium, Coscinodiscus endoi, C. flexuosus, C. yabei, C. lewisianus, C. marginatus, C. marginatus forma fossilis, C. praeyabei, C. radiatus, C. symbolophorus, Denticula hustedtii, D. lauta, $D$. nicobarica, D. punctata, Hemiaulus c.f. polymorphus, Mediaria splendida, Nitzschia challengeri, $N$. porteri, Rhizosolenia miocenica, $R$. praebarboi, $R$. styliformis, Rouxia diploneides (extinction upper part of this zone), $R$. naviculoides (first occurrence upper part of this zone), Stephanopyxis turris, Synedra jouseana, Thalassiothrix longissima, Thalassionema nitzschioides, Triceratium cinnamomeum, and Coscinodiscus vetustissimus. Kanaya and Koizumi (1970) correlate the extinction of Coscinodiscus lewisianus with the base of the planktonic foraminiferal zone N.11 (Blow, 1969). Burckle (1972) found Coscinodiscus yabei in equatorial Pacific sediments at a level correlative with the Globorotalia fohsi peripheroacuta Zone N.10 of Blow (1969) with an approximate absolute age of 13 m.y. using Berggren's (1969) time scale. Burckle (1972) found Nitzschia porteri also present within the N.11 foraminiferal zone, but on his figure 3 , he placed the extinction level of Nitzschia porteri within the magnetic epoch 11, which is correlative to the N.12 to N.13 foraminiferal zones.

Subzones: No subzones have been defined.

Paleomagnetic stratigraphy: No correlations with paleomagnetic stratigraphy have been made.

Comparison with zonations of other workers: Zone XXI correlates in part with the Diatom Zone I of Kanaya (1971), with the planktonic foraminiferal Zones N.10 and N.11 of Blow (1969), with the Miocene Wonosari Series of Java of Reinhold (1937), with the NN6 calcareous silicoflagellate nannofossil zone of Martini (1971), with the Corbisema triacantha Zone of Martini in the Experimental Mohole (personal communication 1972), and with the Dorcadospyris alata radiolarian zone of Riedel and Sanfilippo (1971).

Absolute age: The base of this zone has not been dated; the top has an extrapolated age of 13.5 m.y. using Berggren's time scale (1969).

Geographical extent: Found in equatorial and North Pacific sediments.

Type locality: DSDP Leg 18, Site 173, Sample 26-1(120-121 cm) to Sample 26(CC).

\section{North Pacific Diatom Zone XXII}

Definition: The base of this zone is defined by the first appearance of Rhizosolenia praebarboi and the extinction of Rhaphoneis miocenica, the top by the first occurrences of Cladogramma dubium, Coscinodiscus yabei, and Nitzschia challengeri.

Discussion: The zone is characterized by the occurrence of Actinocyclus ingens, Bruniopsis mirabilis, Coscinodiscus lewisianus, C. marginatus, C. marginatus forma fossilis, C. praeyabei, C. symbolophorus, Denticula hustedtii, D. lauta, D. nicobarica, D. punctata, Hemiaulus c.f. polymorphus, Mediaria splendida, Rhizosolenia miocenica, R. praebarboi, Rouxia deploneides, Stephanopyxis turris, Synedra jouseana, Thalassionema nitzschioides, and Thalassiothrix longissima. The first occurrence of Coscinodiscus yabei is reported by Kanaya and Koizumi (1970) to correlate with the base of the planktonic foraminiferal Zone N.10 of Blow (1969). Burckle (1972) points out that Coscinodiscus yabei is a 
good Middle Miocene marker ranging to the middle of geomagnetic epoch 8. Koizumi (1968) established Oga Diatom Zone I which represents the upper part of the Coscinodiscus yabei Assemblage of Kanaya (1959). The Oga Diatom Zone I correlates with the lower part of the Globorotalia bykovae Zone (Saito, 1963) and is of Middle Miocene age but lacks Coscinodiscus lewisianus. Sawamura (1963) found the Coscinodiscus yabei Zone in the upper part of the Oidawara Formation which is correlative (Saito, 1963) with the Globorotalia fohsi barisanensis Zone (upper part of N.9 of Blow, 1969). The Oga Diatom Zone I (Koizumi, 1968) extends from the lower to the upper part of the Onnagawa Formation, directly overlying the Globorotalia fohsi fohsi foraminiferal zone, its base coinciding with that of Globorotalia bykovae Zone. The Coscinodiscus yabei Assemblage (Kanaya, 1959) occurs in the diatomaceous mudstone of the Middle Miocene Onnagawa and its correlative formations in Akita and Aomori Prefectures, northeastern Japan, but all these zones lack Coscinodiscus lewisianus and are probably younger than Zone XXII.

Subzones: In the upper part of this zone, Rouxia diploneides has its first evolutionary appearance from its ancestor Rouxia californica. The same is true for Nitzschia porteri, which is derived from an undescribed ancestor (Schrader, in preparation).

Paleomagnetic stratigraphy: No correlations with paleomagnetic stratigraphy have been made.

Comparison with zonations of other workers: Zone XXII is certainly older than the Coscinodiscus yabei Assemblage of Kanaya (1959) and the Oga Diatom Zone 1 and its correlative sequences of Koizumi (1958). The zone underlies the Discoaster exilis-Cyclococcolithus neogammation calcareous nannofossil subzone of Milow (1970) of Middle Miocene age (N.9-N.10).

Absolute age: Absolute ages have not been estimated.

Geographical extent: Found in equatorial and North Pacific sediments.

Type locality: DSDP Leg 18, Site 173, Sample $27-1(107-108 \mathrm{~cm})$ to Sample 27(CC).

\section{North Pacific Diatom Zone XXIII}

Definition: The base of this zone is defined at the first occurrence of Bruniopsis mirabilis, Coscinodiscus endoi, Rhizosolenia miocenica, Denticula punctata, and Denticula hustedtii; the top at the first occurrence of Rhizosolenia praebarboi and the extinction of Rhaphoneis miocenica.

Discussion: The zone is characterized by the occurrence of Actinocyclus ingens, Asteromphalus robustus, Bruniopsis mirabilis, Coscinodiscus endoi, C. lewisianus, $C$. marginatus, $C$. marginatus forma fossilis, $C$. praeyabei, $C$. symbolophorus, Denticula hustedtii, D. hyalina, D. lauta, D. punctata, D. nicobarica, Hemiaulus c.f. polymorphus, Mediaria splendida, Rhaphoneis miocenica, Rhizosolenia miocenica, Stephanopyxis turris, Synedra jouseana, Thalassionema nitzschioides, and Thalassiothrix longissima. Kanaya and Koizumi (1970) correlate the first occurrence of Denticula hustedtii in North Pacific sediments with the base of the N.11 planktonic foraminiferal zone of Blow (1969); Kanaya and Simonsen (1961) found Denticula hustedtii in Californian land sections first within the lower Mohnian (correlative with the base of N.13, Berggren, 1969). Mediaria splendida first occurs at the top of the foraminiferal zone N.10 both in North Pacific sediments and in sediments of the west coast of North America (Kanaya and Koizumi, 1970). Sheshukova-Poretskaya (1967) found this species restricted to the lower layer of her diatom section of Schmidt Peninsula. No information is available from the literature on the other species.

Subzones: No subzones have been defined.

Paleomagnetic stratigraphy: No correlations with paleomagnetic stratigraphy have been made.

Comparison with zonations of other workers: Zone XXIII correlates in part with the lower Mohnian stage of California according to Kanaya and Simonsen (1961), with the lower diatom section of Schmidt Peninsula of Scheshukova-Poretskaya (1967), and with the Discoaster exilis-Cyclococcolithus neogammation calcareous nannofossil zubzone of Milow (1970).

Absolute age: No absolute ages have been estimated.

Geographical extent: Found in North Pacific sediments.

Type locality: DSDP Leg 18, Site 173, Sample $28-1(100-101 \mathrm{~cm})$ to Sample $29-1(55-56 \mathrm{~cm})$.

\section{North Pacific Diatom Zone XXIV}

Definition: The base of this zone is defined by the first occurrence of Coscinodiscus lewisianus; the top by the first occurrences of Bruniopsis mirabilis, Coscinodiscus endoi, Coscinodiscus praeyabei, Rhizosolenia miocenica, and Denticula punctata.

Discussion: The zone is characterized by the occurrence of Actinocyclus ingens, Coscinodiscus lewisianus, $C$. praeyabei, C. marginatus, C. marginatus forma fossilis, $C$. symbolophorus, Denticula nicobarica, Hemiaulus c.f. polymorphus, Rhaphoneis miocenica, Rhizosolenia styliformis, Stephanopyxis turris, Thalassionema nitzschioides, Thalassiothrix longissima, and Triceratium condecorum. Burckle (1972) points out that Coscinodiscus lewisianus is a good guide fossil of the early middle part of the Middle Miocene. Kanaya and Koizumi (1970) correlate the range of Coscinodiscus lewisianus with the planktonic foraminiferal zone N.9 of Blow (1969). Reinhold (1937) gives a range of Coscinodiscus lewisianus from his Upper Miocene to lower Middle Miocene. He found it occurring in the Wonosari Series of Java which Reinhold correlates with the "lower middle Miocene with the Temblor Horizon in California." Wornardt (1967) found it ranging up to late Miocene in California but gave no estimates of abundance or the possibility of reworking of older fossils into younger strata within the Monterey Formation. Coscinodiscus endo $i$ first occurs at the base of the foraminiferal zone N.10 (Kanaya and Koizumi, 1970). Burckle (1972) found it in rare abundances in his oldest examined sediments from the equatorial Pacific correlative to the Globorotalia fohsi peripheroacuta (N.10) Zone of Blow (1969).

Subzones: No subzones have been defined. 
Paleomagnetical stratigraphy: No correlations with paleomagnetic stratigraphy have been made.

Comparison with zonations of other workers: Zone XXIV correlates in part with the Wonosari Formation of Java according to Reinhold (1937) and with the Globorotalia fohsi peripheroacuta (N.10) Zone of Blow (1969).

Absolute age: No absolute age estimates have been made.

Geographical extent: Found in North Pacific and equatorial Pacific sediments and in land sections from California and Java.

Type locality: DSDP Leg 18, Site 173, Sample 29-2(57-59 $\mathrm{cm})$ top to Sample 30(CC).

\section{North Pacific Diatom Zone XXV}

Definition: The base of this zone is not defined; the top is defined at the first occurrence of Coscinodiscus lewisianus.

Discussion: The zone is characterized by the occurrence of Actinocyclus ingens, Coscinodiscus marginatus, $C$. marginatus forma fossilis, Denticula nicobarica, Rhaphoneis miocenica, Stephanopyxis turris, Thalassionema nitzschioides, Thalassiothrix longissima, and Triceratium condecorum. Kanaya and Koizumi (1970) correlated the range of Triceratium condecorum on the west coast of North America with planktonic foraminiferal zones N.14 to N.8 of Blow (1969).

Subzones: No subzones have been defined.

Paleomagnetic stratigraphy: No correlations with paleomagnetic stratigraphy have been made.

Comparison with zonations of other workers: Zone XXV correlates in part with the lower Tremblor Formation of California (Pyramid Hill Fauna of Hanna, 1932), which according to Mandra (1960) is in the uppermost upper Relizian Stage, just below the Luisian. This would place it in the upper N.8 to lower N.9 zones using Berggren's time scale (1969).

Absolute age: No absolute ages have been estimated.

Geographical extent: Found in North Pacific sediments and in land sections from California.

Type locality: DSDP Leg 18, Site 173, Sample $30(\mathrm{CC})$ top to Sample $31-1(130-132 \mathrm{~cm})($ ?) (base of this zone has not been defined).

\section{CORRELATION WITH OTHER PACIFIC SECTIONS}

The ages and the correlation of some land-based diatom sequences in the northern circum-Pacific region are not well established. Partly as a test of the geographical extent of applicability of diatom biostratigraphy developed from DSDP Leg 18, land sections from California, Japan, and the Experimental Mohole have been compared with the North Pacific Diatom Zonation described above.

\section{SYSTEMATIC SECTION, FLORAL REFERENCE}

The genera are arranged alphabetically and species alphabetically within each genus Species and varieties are treated according to the classifications of Hustedt (1930), Sheshukova-Poretskaya (1967), and others whose descriptions have been followed strictly in identifying species. Descriptions with discussions are given for those species which have not been treated sufficiently in the literature. New species have been described and their holotypes and paratypes designated. Holotypes are deposited in the author's type collection. Paratypes and paratype material have been deposited in the $\mathrm{Dr}$. Friedrich Hustedt Arbeitsplatz fur Diatomeenkunde, Institut fur
Meeresforschung, Bremerhaven (Site 173) and at Lamont-Doherty Geological Observatory, Palisades, New York (Site 173). Unidentified species are numbered and illustrated and will be treated in a supplementary paper. An attempt was made to catalogue all diatom species in the samples.

\section{Genus ACTINOCYCLUS Ehrenberg (1837) \\ Actinocyclus cubitus Hanna and Grant (1926) \\ (Plate 19, Figure 7)}

Description: Hanna and Grant (1926), p. 118, pl. 11, fig. 3 .

Several specimens were found in Pliocene sediments at Site 173. They look exactly like those illustrated by Hanna and Grant.

\section{Actinocyclus curvatulus Janisch in A. Schmidt (1878)} (Plate 19, Figure 2)

Description: Hustedt (1930), p. 538, fig. 307. Specimens were identified as Act. curvatulus whenever a pseudonodule was found, otherwise they were identified as Coscinodiscus curvatulus Grunow. Margin finely striated with 18 striae in $10 \mu$.

\section{Actinocyclus divisus (Grunow) Hustedt (1958)}

Description: Hustedt (1958), p. 129-130, pl. 8, fig. 81; Hustedt (1930), p. 411, fig. 218 as Coscinodiscus divisus Grunow.

DSDP Leg 18 occurrences: Found quite often in Holocene to Pleistocene sediments from the northern sites. No illustration.

\section{Actinocyclus ehrenbergii Ralfs in Pritchard (1861)} (Plate 19, Figure 1)

Description: Hustedt (1930), p. 525-532, numerous figures. No subdivisions of this species have been made. The taxonomy needs revision which is beyond the scope of this investigation. Found quite often in Neogene sediments all over the North Pacific.

\section{Actinocyclus ellipticus Grunow in Van Heurck (1881)} (Plate 8, Figures 7-9, 11-14, 16, 17)

Description: Hustedt (1930), p. 533, fig. 303

Actinocyclus ellipticus Grun. var. moronensis (Deby) Kolbe (1954) (Plate 24, Figure 15)

Description: Kolbe (1954), p. 21, pl. III, figs. 29-30.

Actinocyclus ingens Rattray (1890) (Plate 18, Figures 1-4,7)

Description: Kanaya (1971), p.554, numerous figures; Koizumi (1968), p. 207-208, pl. 32, figs. 5-6.

Actinocyclus ochotensis Jouse (1961) illustration only. (Plate 18, Figures 8, 15(?), 17; Plate 19, Figure 6)

Description: Koizumi (1968) p. 208, pl. 32, figs. 7-10; Donahue (1970), p. 135 , pl. 2, figs. 2-5. Valve discoid, almost flat, $20-48 \mu$ in diameter. Areolae hexagonal to round, $4-8$ in $10 \mu$ near the center, becoming smaller towards the margin. Central hyaline area usually present, $2.5-12 \mu$ in diameter. Aereolae tend to make fascicles in the inner half of the radius. The structure is interrupted near the margin by an irregular narrow hyaline zone. Fascicles not developed when pores are sparse and irregularly distributed. Pseudonodule filled with small aereolae, present on the margin outside the hyaline zone. Margin $1.5-2 \mu$ wide, radially striated, $14-15$ striae in $10 \mu$.

Actinocyclus oculatus Jousé (1961) illustration only. (Plate 18, Figures 5, 6, 9-14, 16, 18, Plate 19, Figure 5)

Description: Koizumi (1968), p. 208, pl. 32, figs. 11-14; Donahue (1970), p. 135, pl. 2, fig. 6-7.

\section{Genus ACTINOPTYCHUS Ehrenberg (1839)}

Actinoptychus splendens (Shadb.) Ralfs in Pritchard (1861)

(Plate 22, Figures 10, 11, 13, 14, 16)

Description: Hustedt (1930), p. 478-479, fig. 265.

Discussion: No attempts have been made to split this group. All 
species of the genus Actinoptychus which possess more than 6 alternately raised and depressed sectors are included in this species. This whole group needs revision.

\section{Actinoptychus undulatus (Bail.) Ralfs in Pritchard (1861)} (Plate 22, Figures 4, 12, 15, 17(?))

Description: Hustedt (1930), p. 475-478, fig. 264.

\section{Genus ARACHNOIDISCUS Deane ex Pritchard (1852)}

Several broken specimens and complete frustules have been found in the coarser fractions. No attempts have been made to treat this group taxonomically.

\section{Genus ASTEROLAMPRA Ehrenberg (1845)}

Asterolampra grevillei (Wall.) Greville (1860) (Plate 21, Figure 3)

Description: Hustedt (1930), p. 489-491, fig. 274.

Asterolampra marylandica Ehrenberg (1845) (Plate 21, Figure 2)

Description: Hustedt (1930), p. 485-487, fig. 271.

Asterolampra sp. 1 Schrader (Plate 21, Figure 8)

Description: This species resembles $A$. grevillei but differs in the much coarser sectors, here 11-12 hexagonal areolae occur in $10 \mu$.

Genus ASTEROMPHALUS Ehrenberg (1844)

Asteromphalus hookeri Ehrenberg (Plate 21, Figure 6)

Description: Hustedt (1958),p. 127-128, pl. 8, figs. 88-90.

Asteromphalus robustus Castracane (1875)

(Plate 21, Figures 4, 5, 7)

Description: Hustedt (1930), p. 496-498, fig. 278.

Genus BACTEROSIRA Gran (1900)

Bacterosira fragilis Gran (1900)

(Plate 16, Figure 7)

Description: Hustedt (1930), p. 544, figs. 310.

Genus BIDDULPHIA Gray (1821)

Biddulphia aurita (Lyngb.) Brebisson et Godey (1838)

(Plate 13, Figures 1-3)

Description: Hustedt (1930), p. 846-849, figs. 500-502.

Biddulphia calamus Brun et Tempere (1889) (Plate 13, Figure 15)

Description: Brun and Tempere (1889), p. 26-27, pl. 5, fig. 15.

Discussion: Here found usually as fragments which could be referred to this species after a complete specimen had been observed in the coarser fractions.

Biddulphia toumeyi (Bailey) Roper (1859)

Description: Hustedt (1930),p. 834-836), fig. 491.

DSDP Leg 18 Occurrences: Several individuals have been found. This species inhabits the marine-littoral environment.

\section{Genus BRUNIOPSIS (Tempere) Karsten (1928) \\ Bruniopsis mirabilis (Brun) Karsten (1928) (Plate 13, Figure 16)}

Description: As Brightwellia ? mirabilis Brun in Brun and Tempere (1890), p. 27, pl. 8, fig. 1, Bruniopsis mirabilis Kolbe (1954), p. 24, pl. IV, fig. 44, Kanaya (1971), p. 555.

DSDP Leg 18 occurrences: Represented only by fragments in the lower part of Site 173.
Genus CHAETOCEROS Ehrenberg (1844)

Chaetoceros species were found quite often within the pelagic sequences. They are represented mostly as spores. No attempts have been made to treat this genus systematically. On Plate 17, Figures $1-15$, the most abundant forms are illustrated. They include Dicladia pylea Hanna et Grant (= Chaetoceros mitra), Chaetoceros debilis Cleve, Chaetoceros cinctus Gran among others, Chaetoceros subsecundus Hustedt, Dicladia capreolus Ehrenberg, and Chaetoceros pliocenus Brun.

\section{Genus CLADOGRAMMA Ehrenberg (1954)}

Cladogramma dubium Lohmann (1948)

(Plate 13, Figures 17, 18, 21; Plate 24, Figure 11(?))

Description: Lohmann (1948), p. 168, pl.9, fig. 5; SheshukovaPoretskaya (1967), p. 192, pl. 24, fig. 6; pl. 29, fig. 4 .

\section{Genus COCCONEIS Ehrenberg (1838)}

No attempts have been made to identify all species of Cocconeis found at the various sites. Most species of this genus can only be identified if both valves are present. The genus Cocconeis is characteristic either of littoral-marine or freshwater biofacies. Among others the following species could be identified.

\section{Cocconeis placentula Ehrenberg (1838)}

Description: Hustedt (1959), p. 347-350, figs. 802-803.

DSDP Leg 18 occurrences: Found at sites bearing hemipelagic sediments.

\section{Cocconeis vitrea Brun (1891)}

Description: Brun (1891), p. 19,pl. 18, fig. 2.

DSDP Leg 18 occurrences: Coarse fraction at Site 173. No illustration.

Genus COSCINODISCUS Ehrenberg (1838)

Coscinodiscus curvatulus Grunow in A. Schmidt (1878)

Description: Hustedt (1930), p. 406-410.

DSDP Leg 18 occurrences: Found quite frequently in Pleistocene North Pacific sediments. No illustration.

\section{Coscinodiscus endoi Kanaya (1959)}

(Plate 7, Figures 14, 21; Plate 20, Figures 1, 2)

Description: Kanaya (1959), p. 76-77,pl. 3, figs. 8-11; Koizumi (1968), p. 211, pl. 32, figs. 21-22.

Discussion: This species is very similar to Coscinodiscus tabularis var. egregius (Rattr.) Hustedt (1930), p. 428, but can be easily distinguished from that species by its excentric central nodule and the wider hyaline ring around the margin.

Coscinodiscus flexuosus Brun (1895) illustration only. (Plate 7, Figures 6, 7(?), 10-13, 15, 16)

Description: Valve circular, $20-30 \mu$ in diameter, surface with tangential plication, one side concave, the other convex. Central area absent. Areolae circular, radially arranged in a complete meshwork over the valve, 6-7 areolae in $10 \mu$, slightly increasing in size toward the margin. Areolae form fascicles. Secondary spiral structure of areolae well developed. Margin clearly defined, flat, $2 \mu$ wide, radially striated $10-12$ striae in $10 \mu$; marginal structure separated from the valve structure by a hyaline area. Margin subdivided into equal sections by inner marginal, radially arranged ribs, 5-6 of marginal striae between each rib.

Discussion: Distinguished from Coscinodiscus yabei Kanaya (1957) by the circular areolae, by its small margin, and by the structure of the marginal area.

DSDP Leg 18 occurrences: Found in temperate and tropical Pacific sediments of Miocene age.

\section{Coscinodiscus lacustris Grunow forma indet.} (Plate 6, Figure 24)

Description: Hustedt (1930), p. 432-433, fig. 235.

Discussion: It is not certain that the forms described here are 
correctly identified as Coscinodiscus lacustris. They resemble $C$. lacustris var. hyperborea Grunow. They differ from Coscinodiscus plicatus by the finer structure, $12-13$ areolae in $10 \mu$, by the more finely striated margin, 16 striae in $10 \mu$, and by the presence of two rows of spines, one close to the margin with around 3 spines in $10 \mu$ and the other inside with isolated spines.

\section{Coscinodiscus lewisianus Greville (1866)}

(Plate 8, Figures 1-6, 10, 15)

Description: Kanaya (1971), p. 555, pl. 40.5, fig. 4-6.

\section{Coscinodiscus lineatus Ehrenberg (1838)}

Description: Hustedt (1939), p. 392-393, fig. 204.

DSDP Leg 18 occurrences: Found in varying abundance in the Holocene to Pleistocene and Pliocene sections. No illustration.

Coscinodiscus marginatus Ehrenberg (1841)

(Plate 20, Figures 7, 10, 12,13)

Description: Hustedt (1930), p. 416-418, fig. 223.

Coscinodiscus marginatus Ehrenberg forma fossilis Jousé (1961) illustration only

(Plate 20, Figure 12)

Discussion: Differs from $C$. marginatus by its convex valve surface, by the inner structure of the areolae, and by the double-chambered margin.

DSDP Leg 18 occurrences: Found in North Pacific sediments of Pliocene and Miocene Age.

\section{Coscinodiscus miocenicus Schrader nova species.} (Plate 7, Figures 11, 12)

Description: Valve circular $10-15 \mu$ in diameter, surface with tangential plication, one side concave, the other convex. Central area absent. Areolae circular, arranged in radial rows, areolae of the same size over the entire valve, 7 areolae in $10 \mu$. Marginal structure not distinguished from the valve structure. Margin 1-1.5 $\mu$ wide, each radial line ends in a marginal chamber formed by two inner marginal, radially arranged ribs.

Discussion: Differs from the other plicate species of Coscinodiscus by its smaller size, the radial lines, and the structural arrangements of the margin.

Holotype: Plate 7, Figures 11-12; from DSDP Leg 18, Sample 173-26-4(55-56cm), northeast Pacific, off northern California.

\section{Coscinodiscus monicae Grunow in Rattray (1889)}

Description: Rattray (1889), p. 563; illustration: Hanna (1932), p. 182, pl. 9, fig. 2; Wornardt (1967), p. 27, fig. 29; Kanaya (1971), pl. 40.1 , fig. 2 .

DSDP Leg 18 occurrences: Found in the lower part of Hole 173 in varying abundance. No illustration.

\section{Coscinodiscus nodulifer A. Schmidt (1878)}

Description: Hustedt (1939), p. 426-427, fig. 229

Discussion: Distinguished from $C$. vetustissimus Pant. by the irregularly arranged areolae, by the more coarsely striate margin, and by the marginal spines.

DSDP Leg 18 occurrences: Found in temperate and equatorial Pacific sediments of Miocene age.

\section{Coscinodiscus paleaceus (Grunow) Rattray (1889)}

(Plate 3, Figures 10-12)

Description: Kolbe (1954), p. 34, pl. III, fig. 32.

Discussion: Kanaya (1971) synonymizes Cymatosira andersoni Hanna (1932) with Coscinodiscus paleaceus. They are, however, quite different: Coscinodiscus paleaceus never shows a central area as does $C$. andersonii.

\section{Coscinodiscus plicatus Grunow (1884)}

(Plate 6, Figure 23)

Description: Grunow (1884), p. 86 pl. III, figs. 10, 27; Kolbe
(1954), p. $34-35$, no illustration. Valve circular $25-40 \mu$ in diameter, surface with tangential plication, one side concave, the other side convex. Central area absent. Areolae polygonal, forming a close network over the entire valve. Areolae 9 in $10 \mu$ near the center of the valve, slightly increasing in size outwardly, decreasing in size near the margin. Margin small, $1 \mu$ in bread th, not separated from the valve structure. Radially striated 13 striae in $10 \mu$. Small spines between the marginal striae, 3 in $10 \mu$.

Discussion: C. plicatus differs from C. yabei, C. praeyabei, $C$. miocenicus, and $C$. flexuosus by the spiny margin and the polygona areolation over the valve surface. It very much resembles Coscinodiscus lacustris but differs from it by the finer areolation and the coarser spiny margin.

\section{Coscinodiscus praepaleaceus Schrader nova species} (Plate 3, Figures 1-9)

Description: Valve ovate, flat, margin well developed, narrow lanceolate, with acute apex. Valve symmetrical, $20-55 \mu$ long, 6-10 $\mu$ in breadth. Central area not present. Structure bilateral, hyaline in light microscope, with $6-8$ transapical ribs in $10 \mu$ reaching to the middle of the valve. Ribs from one side little off set from ribs on the other side connected by a zig-zag central apical rib.

Discussion: This species resembles in shape Coscinodiscus paleaceus but differs by the rib structure. The exact position within the Coscinodiscus group is problematic and needs further electron-microscopical investigation. No information about this species is given in the literature.

Holotype: Plate 3, Figures 1, 2; from DSDP Leg 18, Sample 173-17-3 (55-56 cm), northeast Pacific, off northern California.

Paratypes: Plate 3, Figures 3-9.

Coscinodiscus praeyabei Schrader nova species

(Plate 6, Figure 16; Plate 7, Figures 17-20, 22, 23)

Description: Valve circular $18-35 \mu$ in diameter, surface with tangential plication, one side concave, the other side convex. Central area absent. Areolae polygonal to circular (more common), arranged in radial rows with one row of areolae in the middle part of the valve and two to three rows at the outer part of the valve. Areolae $7-8$ in $10 \mu$ near the center, slightly increasing in size outwardly, then decreasing in size in the outer third of the valve. Margin separated from the valve structure by a hyaline ring, $1.5-3 \mu$ in breadth. Each radial row ends in a chamber of two marginal ribs.

Discussion: Differs from Coscinodiscus yabei, C. flexuosus, C. plicatus, and $C$. lacustris by the special arrangement of the radial rows and the structure of the margin.

Holotype: Plate 7, Figures 22, 23; from DSDP Leg 18, Sample 173-29-1(55 56cm) northeast Pacific, off northern California.

Paratype: Plate 6, Figure 16, Plate 7, Figures 17-20.

\section{Coscinodiscus radiatus Ehrenberg (1839)}

Description: Hustedt (1930), p. 420, fig. 225.

DSDP Leg 18 occurrences: Found in temperate and tropical Pacific sediments of Cenozoic age. No illustration.

\section{Coscinodiscus rothii (Ehrenberg) Grunow in Schneider (1878)}

Description: Hustedt (1930), p. 400-406, figs. 210-213.

DSDP Leg 18 occurrences: Found at Site 173 in various abundances. No illustration.

\section{Coscinodiscus symbolophorus Grunow (1884)}

(Plate 22, Figures 8,9)

Description: Hustedt (1930), p. 396-398, fig. 208 as Coscino. discus stellaris var. symbolophora (Grun.) Jörgensen (1905).

Discussion: Valves strongly convex, at times nearly hemispherical, $18-140 \mu$ in diameter, with a characteristic dark asterisk-like figure at the center of the valves. Areolae small, hexagonal, in a network of rows grouped in broad bands. Within a band, the arealae rows are parallel to the middle one. The bands are at times inconspicuous. The secondary concave tangential rows of areolae are quite distinct. The areolae increase in size appreciably from the center of the valve toward the margin, from 9-14 in $10 \mu$, to 10 in $10 \mu$. Margin narrow, inner part striated, up to 20 striae in $10 \mu$, outer part hyaline. 
Coscinodiscus stellaris Roper (1858) (Plate 26, Figure 7)

Description: Hustedt (1930), p. 396-398, fig. 207.

DSDP Leg 18 occurrences: Found at all sites in various abundance.

\section{Coscinodiscus tabularis Grunow var. egregius (Rattr.) Hustedt (1930)}

(Plate 20, Figure 3, 4)

Description: Hustedt (1930), p. 428 , fig. 230 b.

Discussion: Differs from $C$. endoi Kanaya by the absence of the eccentric central nodule and by the small hyaline submarginal zone.

DSDP Leg 18 occurrences: Found in Holocene and Pleistocene sediments.

Coscinodiscus temperei Brun in Brun and Tempere (1889) (Plate 6, Figures 18, 19; Plate 7, Figures 1-5, 8,9)

Description: Kanaya (1959), p. 84 , pl. 4 , fig. 8.

Discussion: Diagnostic features of this species are the ellipsoidal valves, the plication parallel to the apical axis, radially arranged striae, lack of central area, distinct valve margin, one side with complete areolation, and the other side with a hyaline area between the margin and the structure. Margin radially striated, in the middle of the hyaline area one solitary spine. Other marginal spines smaller. A central spine as reported by Kanaya (1959) has not been observed. The illustrated specimen in Schmidt (1874, pl. 163, fig. 9) shows no central spine. Schmidt says "Auf der Seite pflegt ein langer Dorn vorzustehen, welcher an dem gezeichneten Exemplar abgebrochen war".

\section{Coscinodiscus temperei Brun var. aspinosa Schrader nova var} (Plate 6, Figures 10, 14, 17)

Description: Differs from the species (s.s.) by having no asymmetrical marginal hyaline area, and no middle spine in the hyaline area. Structure at one side of the plication much coarser than on the other side. Valves not as ellipsoidal as the species (s.s.).

Holotype: Plate 6, Figure 17; from DSDP Leg 18, Sample 173-19-3 $(55-56 \mathrm{~cm})$, northeast Pacific, off northern California.

Paratype: Plate 6, Figures 10,14.

\section{Coscinodiscus vetustissimus Pantocsek (1886)} (Plate 22, Figure 2)

Description: Hustedt (1930), p. 412, fig. 220.

Discussion: Similar to $C$. nodulifer, differences discussed under that species.

\section{Coscinodiscus yabei Kanaya (1959)}

(Plate 6, Figures 1-6, 15(?))

Description: Kanaya (1959), p. $86-87$, pl. 5, figs. 5-9. Valve circular $30-60 \mu$ in diameter, surface with a tangential plication, one side concave, the other convex. Central area absent. Areolae polygonal, on one part of the plication circular, arranged in radial rows forming a complete network over almost the entire valve surface. Areolae 6-8 in $10 \mu$ near the center, slightly increasing in size outwardly, and again decreasing toward the margin. Secondary spiral structure of areolae well developed, interrupted by the axis of the plication. Margin clearly defined but not separated from the meshwork, $1.5-4 \mu$ wide, radially striated with inner ribs which form chambers, each of which spans 2-3 areolae.

DSDP Leg 18 occurrences: Found in temperate and tropical Pacific sediments of Miocene age.

\section{Genus CRASPEDODISCUS Ehrenberg (1844) \\ Craspedodiscus coscinodiscus Ehrenberg (1844) (Plate 20, Figure 6)}

Description: Kolbe (1954), p. 36, pl. 1, fig. 4; Kanaya (1971), p. 555 , pl. 40.4 , figs. $1-3$.

\section{Genus CYCLOTELLA Kützing (1833)}

Several species have been found in the terrigenous sediment- bearing sequences. No attempts have been made to treat systematically the recovered freshwater species of Cyclotella.

\section{Genus CYMATOGONIA Grunow (1883) \\ (Plate 26, Figure 8)}

Description: Hanna (1932), p. 186 pl. 10 , fig. 5 .

DSDP Leg 18 occurrences: Found in the lower section of Hole 173 (Middle to Lower Miocene).

$$
\text { Genus CYMATOPLEURA W. Smith (1851) }
$$

Cymatopleura elliptica (Brebisson) Smith (1851)

Description: Hustedt (1930), p. 426-428 figs. 825-827.

DSDP Leg 18 occurrences: Few individuals found. Inhabits freshwater environment. No illustration.

$$
\begin{gathered}
\text { Genus CYMBELLA Agardh (1830) } \\
\text { Cymbella mexicana (Ehrenberg) Cleve (1894) }
\end{gathered}
$$

Description: Cleve (1894), p. 177.

DSDP Leg 18 occurrences: Several individuals found. This species inhabits freshwater environment. No illustration.

\section{Cymbella spp.}

Several other freshwater species of Cymbella were found sporadically. No attempts have been made to treat these systematically.

\section{Genus DENTICULA Kützing (1844) \\ Denticula dimorpha Schrader nova species (Plate 1, Figures 37-46)}

Description: Valves linear-elliptical with bluntly rounded ends, $15-28 \mu$ long, $4-8 \mu$ wide in valve view, $8-10 \mu$ wide in girdle view (complete cells). Pseudoseptae $4-6$ in $10 \mu$, no secondary pseudoseptae. Valve almost hyaline, structure at the margin, on margin 2-3 transapical striae in between the pseudoseptae, largely punctate, 10 transapical marginal striae in $10 \mu$. Raphe marginal. At both poles of the septae on one side of the valve, a strongly silicified thickening which protrudes into the cell interior. The pseudoseptae of one valve penetrate through much of the half frustule and are easily separated from valves and found isolated. The opposite side of the intercalary bands possess one row of small punctae.

Discussion: This species differs from Denticula lauta and Denticula hyalina by the intercalary band, the hyaline valve surface, and the marginal structure. Included in this species are specimens assigned to Denticula lauta Bailey by Simonsen and Kanaya (1961, pl. 1 , figs. 9,10 ).

Holotype: Plate 1, Figure 42, from DSDP Leg 18, Sample 173-20-3(55-56cm), northeast Pacific, off northern California.

Paratype: Plate 1, Figures 37-41, 43-46.

\section{Denticula hustedtii Simonsen et Kanaya (1961)} (Plate 2, Figures 28-34, 36-47)

Description: Simonsen and Kanaya (1961), p. 501, pl. 1, figs. $19-25$; pl. 2 , figs. $36-47$.

\section{Denticula hyalina Schrader nova species (Plate 1, Figures 12-22)}

Description: Valves strongly silicified, elliptical to linearelliptical with broadly rounded ends, $12-40 \mu$ long, $4-9 \mu$ wide, Pseudoseptae about 4 in $10 \mu$, between them short ribs thickened on both mantle sides. Secondary pseudoseptae absent. Valve surface hyaline, a few pores arranged in triangles on both sides of the mantle, approximately 9 in $10 \mu$. The raphe is in most cases situated in the middle of one mantle side. Mantle coarsely punctuate with circular pores, 9 in $10 \mu$, arranged in transapical lines.

Discussion: This species differs from Denticula lauta by its hyaline valve surfaces, the coarsely punctuate mantle sides, and by the situation of the raphe in the middle of one mantle. It differs from Denticula dimorpha by the absence of the intercalary bands and the finer mantle structure. 
Holotype: Plate 1, Figure 21; from DSDP Leg 18, Sample 173-26-4 $(55-56 \mathrm{~cm})$, northeast Pacific, off northern California.

Paratype: Plate 1, Figures 12-20, 22.

\section{Denticula kamtschatica Sabelina (1934)}

(Plate 2, Figures 1-13)

Description: Kanaya and Simonsen (1961), p. 503-504, pl. 1, fig. 14-18.

\section{Denticula lauta Bailey (1854)}

(Plate 2, Figures 14-25, 35)

Description: Simonsen and Kanaya (1961), p. 500-501, pl. 1, figs. 1-8 (non Figs. 9-10 = Denticula dimorpha nov. spec.).

Illustrations: Figure 35 is an atypical specimen; Figure 25 is an atypical specimen, possibly a resting spore.

\section{Denticula miocenica Schrader nova species}

(Plate 2. Figures 16-18)

Description: Valves strongly silicified, linear-elliptical, with broadly rounded ends, $40-45 \mu$ long, $12-15 \mu$ wide. Pseudoseptae 4 in $10 \mu$, strongly silicified, forming inner chambers. Inner openings small, $2-3 \mu$ wide, forming one apical line, this apical line surrounded by two ribs. Between the pseudoseptae a short rib wall thickening on both mantle sides. Secondary pseudoseptae not present. Transapical striae punctuate, about 14 in $10 \mu$, sometimes reduced to one transapical stria near the pseudoseptum. Punctae in quincunx so that oblique rows are formed. Oblique rows more widely separated than the transapical rows. Raphe near the margin, sometimes on the valve surface, eccentric.

Discussion: This species differs from all other species of Denticula by the morphology of the pseudoseptae, forming inner chambers with small inner openings.

Holotype: Plate 2, Figures 26, 27; from DSDP Leg 18, Sample 173-29-2(57-58cm), northeast Pacific, off northern California.

Paratype: Plate 2, Figure 28.

Denticula nicobarica Grunow (1868)

(Plate 1, Figures 31-35) $11-13$.

Description: Simonsen and Kanaya (1961), p. 503, pl. 1, figs.

Denticula punctata Schrader nova species

(Plate 1, Figures 25-30; Plate 3, Figures 16, 17)

Description: Valves strongly silicified, elliptical to linearelliptical with broadly rounded ends, $50-30 \mu$ long, $10-6 \mu$ wide. Pseudoseptae $2-3$ in $10 \mu$, between the pseudoseptae are short rib-wall thickenings on both mantle sides. Secondary pseudoseptae sometimes present in the forma hustedtii. Transapical striae coarsely punctuate, $12-13$ in $10 \mu$, punctae in quincunx, so that oblique rows are formed. Oblique rows not more widely separated than the transapical rows. Raphe marginal.

Discussion: The species differs from all other species of Denticula in its coarse structure; it differs from Denticula nicobarica in its greater size, coarser structure, equal spacing of oblique transapical rows, and occasional presence of secondary pseudoseptae.

Holotype: Plate 1, Figures 27, 28; from DSDP Leg 18, Sample 173-21-3(55-56 cm), northeast Pacific, off northern California.

Paratype: Plate 1, Figures 25, 26, 29, 30; Plate 3, Figures 16, 17 (resting spore ?).

Denticula punctata forma hustedtii Schrader nova forma (Plate 1, Figures 23; 24)

Description: Differs from the species by the secondary pseudoseptae.

Holotype: Plate 1, Figures 23, 24; from DSDP Leg 18, Samples 173-21-1(55-56cm), northeast Pacific, off northern California.

Denticula seminae (Semina) Kanaya and Simonsen (1961) (Plate 1, Figures 1-11, 36, 47)

Description: Simonsen and Kanaya (1961), p. 503, pl. 1, figs. 26-30.
Denticula seminae forma fossilis Koizumi

(Plate 5, Figures 30, 37-38)

Description: $D$. seminae forma fossilis differs from the species by the reduction of the secondary pseudoseptae between the pseudoseptae, by the non-curved polar pseudoseptae, and the enlarged terminations of the pseudoseptae opposite the raphebearing mantle. This form will be described by Koizumi in his DSDP Leg 19 report.

DSDP Leg 18 occurrences: Found in Pliocene sediments.

Genus DIPLONEIS Enrenberg (1944)

Diploneis crabro, Diploneis smithii, Diploneis eudoxia and other species have been found in varying abundance. All recovered individuals inhabit the marine-littoral environment. No attempts have been made to treat this genus systematically.

Genus ENDICTYA Ehrenberg (1845)

Endictya oceanica Ehrenberg (1854)

(Plate 20 Figure 11)

Description: Hustedt (1930), p. 297-298, fig. 136.

Genus EPITHEMIA Brébisson in Brébisson and Gody (1838)

Epithemia turgida (Ehrenberg) Kützing (1844)

Description: Hustedt (1930), p. 387, fig. 733.

DSDP Leg 18 occurrences: Several individuals have been found. Inhabits freshwater environments. No illustration.

\section{Genus ETHMODISCUS Castracane (1886)}

Ethmodiscus rex (Rattray) Hendey (1953) $1-3$

Description: Hendey (1953), p. 51-57, pl. 1, figs. 1-6, pl. 2 figs.

DSDP Leg 18 occurrences: Found only in fragments. No illustration.

\section{Genus EUNOTIA Ehrenberg (1837)}

Species belonging to this genus were found sporadically. No attempts have been made to treat these systematically. All species are freshwater inhabitants.

\section{Genus GLYPHODISCUS Greville (1862) \\ Glyphodiscus stellatus Greville (1862) \\ (Plate 22, Figure 6)}

Description: Greville (1862), p. 91, pl. 9, fig. 5; Wornardt (1967), p. 58, fig. 120a.

\section{Genus GOMPHONEMA Agardh (1824)}

Species belonging to this freshwater genus have been found sporadically; no attempts have been made to treat these systematically.

\section{Genus HEMIAULUS Ehrenberg (1844)}

Hemiaulus cf. polymorphus Grunow (1884)

Description: Hustedt (1930), p. 880-881, figs. 525-526.

Discussion: Several specimens in the lower part of Hole 173 resemble $\mathrm{Hem}$. polymorphus but lack the pseudoseptae. Problems concerning the systematics of the genus Hemiaulus are not dealt with in this paper.

\section{Hemiaulus sp. 1 Schrader}

(Plate 13, Figure 8-10)

Description: Valve lanceloate in outline, undulate in the middle part. Two transapical constrictions on both sides of the valve. Horns extremely long with an interior spine. Areolae circular, coarse, becoming finer towards the ends of the horns.

DSDP Leg 18 occurrences: Found in the lower part of Hole 173. 
Hemiaulus sp. 2 Schrader

(Plate 13, Figure 11)

Description: Only fragments were found in the lower part of Hole 173. Horns long with tubular apex.

\section{Hemiaulus sp. 3 Schrader \\ (Plate 13, Figure 12)}

Description: Only fragments were found in the lower part of Hole 173. Horns well developed with fine polygonal areolation and dichotomous terminations. Of these, one large spine is curved, extending toward the inside of the valve as seen in girdle view. The other is short and ends bluntly. 173.

DSDP Leg 18 occurrences: Found in the lower part of Hole

\section{Hemiaulus (?) sp. 4 Schrader}

(Plate 13, Figures 13, 14)

Description: Only fragments were found in the upper parts of Holes $173,175,176$, and 178 . Valve fragments hat shaped with radially arranged, polygonal to circular areolation. From the top of the valve two hollow spines arise at an angle of $40^{\circ}$. These spines are strongly silicified at the base. Inclusion of this species in the genus Hemiaulus is most questionable.

DSDP Leg 18 occurrences: Found in the upper parts of Holes $173,175,176$, and 178 .

\section{Genus HEMIDISCUS Wallich (1860) \\ Hemidiscus cuneiformis Wallich (1860) (Plate 24, Figure 14)}

Description: Hustedt (1930), p. 904-907, fig. 542.

DSDP Leg 18 occurrences: Found only in temperate Pacific waters, not found at the northern sites.

\section{Hemidiscus simplicissimus Hanna et Grant, 1926} (Plate 24, Figures 12, 13)

Description: Hanna and Grant (1926), p. 147, pl. 16, fig. 13. Valve flat, ventral margin slightly convex, dorsal margin strongly convex with remarkably highly arched margin. Apical axis $30-45 \mu$ long, transapical axis $30-25 \mu$ long. Small central area present. Valve surface covered with coarse areolae arranged in irregularly radiating fascicles, areolae in short parallel rows in the middle of the valve, 8-9 areolae in $10 \mu$; becoming smaller in size toward the margin, $10-13$ in $10 \mu$. Pseudonodule in the middle of the ventral margin. Additional apiculi not present as in $\mathrm{H}$. cuneiformis.

\section{Genus ISTHMIA Agardh (1832)}

\section{Isthmia nervosa Kützing (1844)}

Description: Hustedt (1930), p. 865-866, fig. 515 .

DSDP Leg 18 occurrences: Several broken frustules of this marine-littoral species have been observed. No illustration.

\section{Genus LITHODESMIUM Ehrenberg (1840)}

\section{Lithodesmium californicum Grunow in Van Heurck (1883)} (Plate 12, Figures 11, 20)

Description: Cells united valve to valve to form short chains. Cells in girdle view rectangular. Valve triangular. Valve margins almost straight, not concave or convex. Valve surface almost flat. Valve surface with an very delicate small central spine which arises from a small elongate conical base. Valve surface finely areolate; areolae arranged in radiating rows from the central hyaline area which forms the base of the spine. Valve edges separated from the middle part of the valve by pseudoseptae which penetrate deeply into the valve interior. Length of side, $30-26 \mu$; areolae increasing in size from the middle to the margin, 12 in $10 \mu$ at margin.

\section{Lithodesmium cornigerum Brun (1896)}

Description: Hanna (1930), p. 189-191, pl. 14, figs. 9-10; Wornardt (1967), p. 67, fig. 131 .

DSDP Leg 18 occurrences: Found in the Pliocene section of Site 173 in fragments. No illustration.
Lithodesmium minusculum Grunow in Van Heurck (1883) (Plate 12, Figures 7(?), 15, 17)

Description: Cells united valve to valve to form short chains. Cells in girdle view rectangular. Valve triangular, length of side $22-30 \mu$. Valve margins convex at the middle, concave near the angles. Valve surface flat, angles projected slightly from the valve surface with a short process and an apiculate apex. Valve surface areolate, areolae arranged in radiating rows from the central hyaline area. Areolae 8-9 in $10 \mu$. Valve surface separated from the angles by steep pseudoseptae. Valves strongly silicified.

\section{Lithodesmium pliocenicum Schrader nova species (Plate 25, Figure 23)}

Description: Cells united by a long central hollow spine. Cells in girdle view rectangular. Valve triangular with slightly convex margins, length of the side $18-24 \mu$. Valve surface with a raised central part. Angles projected slightly from the valve surface with apiculate apex. Central area well built up with a hollow spine, $4 \mu$ in diameter. Central area hyaline with a few scattered areolae. Valve surface areolate, areolae arranged in radiating rows from the central hyaline area. Areolae decreasing in size from the central area toward the margin, $7-8$ in $10 \mu$ in the middle part of the valve. Valves mostly broken, usually only the central area and the strongly silicified spine present.

Discussion: The species has been placed into Lithodesmium because of the lack of smaller spines in the angles or around the valve surface, as in the genus Ditylum.

Holotype: Plate 25, Figure 23; from DSDP Leg 18, Sample 173-14-1(55-56cm), northeast Pacific, off northern California.

\section{Genus MACRORA Hanna (1932) \\ Macrora stella (Azpeitia) Hanna (1932) \\ (Plate 12, Figure 21-24)}

Description: Hanna (1932), p. 196, pl. 12, fig. 7 .

Discussion: This genus is definitely not a diatom, as pointed out by Hanna (1932). But it can be used as a good guide fossil for Middle Miocene sediments.

\section{Genus MEDIARIA Sheshukova-Poretskaya (1962) \\ Mediaria splendida Sheshukova-Poretskaya (1962) (Plate 3, Figure 14, 15)}

Synonym: Trachysphenia australis petit sensu Jousé, 1959.

Description: Sheshukova-Poretskaya (1967), p. 306, pl. XLVII, fig. 14 , pl. XLVIII, fig. 8 .

\section{Mediaria splendida forma tenera Schrader nova forma (Plate 3, Figure 13)}

Discussion: Differs from Mediaria splendida by its smaller size, 70-100 $\mu$ long, 6-8 $\mu$ wide; by its finer structure, 15-16 transapical striae in $10 \mu$; and by coarse punctae, in straight lines, not quincunically arranged. Apical striae approximately $14-15$ in $10 \mu$, parallel to one margin.

Holotype: Plate 3, Figure 13; from DSDP Leg 18, Sample 173-23-2 $(55-56 \mathrm{~cm})$, northeast Pacific, off northern California.

\section{Genus MELOSIRA Agardh (1824)}

\section{Melosira granulata (Ehrenberg) Ralfs in Pritchard (1861)}

Description: Hustedt (1930), p. 248-252, figs. 104-105 .

DSDP Leg 18 occurrences: Found at several sites together with other reworked or displaced freshwater diatoms. This species can be easily transported by wind and is strongly silicified and resists dissolution. No illustration.

\section{Melosira sulcata (Ehrenberg) Kützing (1844) (Plate 20, Figure 9)}

Description: Hustedt (1930), p. 276-278, figs. 118-120.

\section{Genus NAVICULA Bory (1824)}

Species of the genus Navicula were found quite frequently in hemipelagic sediment-bearing sections. Most species have been 
displaced from littoral-marine and freshwater environments. Only the most common species found in Leg 18 material are listed.

Navicula hennedyi W. Smith (1856)

Description: Hustedt (1964) p. 453-464, figs. 1516-1523.

DSDP Leg 18 occurrences: Found in the coarser fractions of Site 173. No illustration.

\section{Navicula lyra Ehrenberg (1841)}

Description: Hustedt (1964) p. 500-514, figs. 1548-1555

DSDP Leg 18 occurrences: Found in the coarser fractions of Site 173. No illustration.

\section{Navicula optima Hanna (1932)}

Description: Hanna (1932), p. 202, pl. 13, fig. 6 .

DSDP Leg 18 occurrences: Found in coarser fractions of Site 173. No illustration.

\section{Navicula praetexta Ehrenberg (1840)}

Description: Hustedt (1964) p. 411-415, figs. 1488-1489.

DSDP Leg 18 occurrence: Found in the coarser fractions of Site 173. No illustration.

\section{Navicula spectabilis Gregory (1857)}

Description: Hustedt (1964), p. 474-483, figs. 1532-1538.

DSDP Leg 18 occurrences: Found in the coarser fraction of Site 173. No illustration.

\section{Genus NITZSCHIA Hassal (1845)}

No attempt has been made in this paper to subdivide the taxa Pseudonitzschia, Fragilariopsis, and Nitzschia. All species belonging to those three genera have been united and treated systematically within the genus Nitzschia (for critical remarks see Hasle, 1965).

\section{Nitzschia californica Schrader nova species}

(Plate 5 Figure 15; Plate 26, Figure 6)

Description: Valves mostly broken into fragments. Observed complete specimen exhibited the following characteristics; valve lanceolate with convex margins and rounded apices, $90 \mu$ long, 7-8 $\mu$ wide; valve surface flat, transapical costae straight over the whole valve, about 9 in $10 \mu$; intercostal membranes usually with two to three rows of punctae arranged in decussate order, punctae sometimes not symmetrical, but scattered over the intercostal membranes; keel distinct, with a central nodule and about 10-11 punctae in $10 \mu$, raphe marginal, valve mantle thin.

Discussion: This species differs from allied species (Nitzschia sp. 2 Schrader) by the elongate valves and the smaller intercostal membranes. No similar species has been described in the literature.

Holotype: Plate 26, Figure 6; from DSDP Leg 18, Sample 173-9-3 $(55-56 \mathrm{~cm})$, northeast Pacific, off northern California.

Paratype: Plate 5, Figure 15.

\section{Nitzchia challengeri Schrader nova species}

(Plate 5, Figures 10-14, 34)

Description: Valves broadly elliptical with parallel margins and broadly rounded apices; $14-10 \mu$ long, $6-5 \mu$ wide. Transapical costae about 10 in $10 \mu$, straight in the middle of the valves, curved near the poles forming a separate apical field with nearly apical costae. Intercostal membrane perforated by two rows of small punctae. Punctae in decussate arrangement, forming oblique rows. Punctae very fine, recognizable only in oblique illumination. Number of costae in the apical field 3-4. Raphe marginal, keel punctae indistinct. Costae strongly silicified

Discussion: This species is very similar to Fragilariopsis curta (van Heurck) Hustedt (1958) but differs from it by the isopolar valves.

Holotype: Plate 5, Figure 10; from DSDP Leg 18, Sample 173-25-2(55.56 cm), northeast Pacific, off northern California.

Paratype: Plate 5, Figures 11-14, 34 (atypical specimen).
Nitzschia cylindrica Burckle (1972)

(Plate 5, Figures 27,32,33)

Description: Burckle (1972), p. 239-240, pl. 2, figs. 1-6.

Nitzschia fossilis (Frenguelli) emend. Kanaya in Kanaya and Koizumi (1970)

(Plate 4, Figures 9-11, 24, 25)

Synonyms: Fragilariopsis pliocena (Brun) Kanaya non Sheshukova-Poretskaya, (1967)

Pseudonitzschia fossilis Frenguelli (1949)

Fragilaria pliocena Brun (1891) only the form illustrated on pl. 17 , fig. 7 (?)

Description: Valves elliptical with slightly convex margins and broadly rounded apices, the middle sometimes more strongly convex, $22-45 \mu$ long, $6-8 \mu$ wide. Transapical costae about 11 in $10 \mu$. Intercostal membranes with two transapical rows of punctae; about 22 in $10 \mu$. Rows punctuate, punctae in decussate arrangement forming oblique rows. Transapical rows and costae near the apices curved. Punctae near the costae, margin strong, raphe marginal.

\section{Nitzschia granulata Grunow var. hispanica Azpeitia (1911)} (Plate 25, Figure 22)

Description: Azpeitia (1911), p. 210-211, pl. 4, fig. 6.

\section{Nitzschia heteropolica Schrader nova species} (Plate 26, Figures 1, 2)

Description: Valves heteropolar, elliptical, with slightly convex margins, one apex broadly rounded, the other acutely rounded; $42-50 \mu$ long, $8-10 \mu$ wide. Transapical costae about 9 in $10 \mu$, straight, curved at the acutely rounded apex with bars connecting in the middle of the valve, forming an angle of more than $90^{\circ}$ Intercostal membranes with two rows of punctae in decussate arrangement. Keel distinct. Raphe marginal. Keel punctae indistinctly connected with costae. One inner row of pores near the raphe lacking margin. Inner pores elliptical, large. Valves flat.

Discussion: This species differs from other species of Nitzschia (N. reinholdii, $N$. praereinholdii, $N$. praefossilis) by the heteropolar valves.

Holotype: Plate 26, Figure 1, 2; from DSDP Leg 18, Sample $173-22-1(55-56 \mathrm{~cm})$

\section{Nitzschia invisa Schrader nova species (Plate 26, Figure 5)}

Description: Valve elliptical with convex margins and rounded apices. About $40 \mu$ long, $10 \mu$ wide. Valve flat, with thinly silicified membranes. Transapical costae hardly visible, about 15 in $10 \mu$, straight, curved outward near the apices. Intercostal membranes homogeneous in normal and oblique illumination. Central nodule distinct. Keel clear with about 12 punctae in $10 \mu$. Raphe marginal. Valve mantle flat.

Discussion: No similar species has been reported in the literature.

Holotype: Plate 26, Figure 5, from DSDP Leg 18, Sample 173-17-3(103-104 cm), northeast Pacific, off northern California.

Nitzschia jouseae Burckle (1972)

(Plate 4, Figure 20, 21, 22-23(?))

Description: Burckle (1972), p. 240, pl. 2, figs. 17-20.

\section{Nitzschia marina Grunow in Cleve and Grunow (1880)} (Plate 4, Figure 17-19)

Description: Grunow in Cleve and Grunow (1880), p. 70.

Nitzschia miocenica Burckle (1972)

Description: Burckle (1972), p. 240-241, pl. 2, fig. 10-15

DSDP Leg 18 occurrences: No illustration. Found very rarely in the Upper Miocene section at Site 173.

\section{Nitzschia porteri Freguelli (1949)}

(Plate 5, Figure 35, 36, 43, 44, 39-41 (atypical specimen))

Description: Frenguelli (1949), p. 116, pl. 1, figs. 33-34. 
Discussion: Mertz (1966) synonymizes Fragilaria pliocena Brun and Nitzschia porteri Freguelli without explanation.

\section{Nitzschia praefossilis Schrader nova species} (Plate 5, Figures 19, 21, 22)

Description: Valves elliptical with slightly convex margins and acute, broadly rounded apices; $65-35 \mu$ long, $10-12 \mu$ wide. Transapical costae 8-9 in $10 \mu$. Intercostal membranes with two rows of rounded pores in decussate arrangement, about 15 in $10 \mu$, punctae forming oblique rows. Rows near the costae. One straight intercostal line between the rows. Transapical costae and rows straight over most of the valve, slightly curved at the apices. One apical line near the border of the raphe lacking margin, forming the inner connection between the inner pore margins. The other border line falls within the margin and is thus not visible. Inner pores eccentric, small. Raphe marginal. Keel strong, about 8 keel punctae in $10 \mu$. In the middle of the valve a marginal central nodule with an enlarged keel punctae. Valves almost flat.

Discussion: The species distinguished from Nitzschia reinholdii and $N$. praereinholdii by the presence of the central nodule, the rounded punctae in the intercostal membranes, and the marginal inner pores.

Holotype: Plate 5, Figure 21, 22; from DSDP Leg 18, Sample 173-18-3 $(56-57 \mathrm{~cm})$, northeast Pacific, off northern California.

Paratype: Plate 5, Figure 19.

\section{Nitzschia praereinholdii Schrader nova species} (Plate 5, Figures 20, 23-26)

Description: Valves elliptical with slightly convex margins and slightly acute, broadly rounded apices; $40-55 \mu$ long, $7-9 \mu$ wide. Transapical costae 7-10 in $10 \mu$. Intercostal membranes with two rows of sixedged pores in decussate arrangement, 15 in $10 \mu$, forming a zig-zag intercostal median transapical line. Punctae forming oblique rows. Transapical costae and rows near the apices straight as on the rest of the valve. Two apical lines near the margins forming the boundaries of the inner pore openings. Inner pores wide, lanceolate. Raphe marginal, keel strong, about 7-9 keel punctae in $10 \mu$. Valves slightly curved in transapical direction with raised lanceolate medial part.

Discussion: Distinguished from Nitzschia reinholdii by the coarser punctae, the wide inner openings, and the wider costae. This species seems to be the ancestor of Nitzschia reinholdii.

Holotype: Plate 5, Figure 24, 25; from DSDP Leg 18, Sample 173 16-2 $(55-56 \mathrm{~cm})$, northeast Pacific, off northern California.

Paratype: Plate 5, Figures 20,23 26.

Nitzschia reinholdii Kanay a et Koizumi, 1970

(Plate 4, Figures 12-16; Plate 5, Figures 1-9)

Synonyms: Nitzschia pliocena (Brun) Wornardt (1967)

Fragilariopsis pliocena (Brun) Sheshukova-Poretskaya (1967)

Fragilaria pliocena Brun (1891)(partim; Plate 14, Figure 7).

Fragiliariopsis pliocena (Brun) Koizumi (1968) non SheshukovaPoretskaya (1967).

Fragilaria pliocena Brun in Reinhold (1937)

Description: Valves elliptical with slightly convex margins; $42-65 \mu$ long, $9-12 \mu$ wide. Apices slightly acute, broadly rounded. Transapical costae $10-12$ in $10 \mu$, between the costae (intercostal membranes) two transapical rows, near the costae, about 20 in $10 \mu$. Rows punctate, about 22 punctae in $10 \mu$. Punctae in decussate arrangement forming oblique rows. Transapical costae and rows slightly rounded near the apices. Two apical lines near the raphe-lacking margin at the interior side of the valves forming the inner openings of the inner pores. Inner pores small elliptical. Raphe marginal, keel strong. About 13 keel punctae in $10 \mu$.

Discussion: This species has not been defined clearly in the literature. Kanaya and Koizumi (1970) give a very brief description in Japanese without illustration, and refer to an unpublished manuscript. The species is similar to Nitzschia marina but differs by the raphe not being inturned at the apices, and by the absence of a double inner pore line.
Nitzschia rolandii nova species

(Plate 5, Figures 31, 42(?); Plate 26, Figures 3, 4)

Derivatio nominis: Dedicated to Roland von Huene, Co-Chief Scientist of DSDP Leg 18.

Description: Valves elliptical with parallel margins and broadly rounded ends; $16-30 \mu$ long, $5-6 \mu$ wide. Transapical costae about 10 in $10 \mu$, straight, slightly curved at the apices. Intercostal membranes homogeneous, finely punctuate in oblique illumination. Raphe marginal, keel distinct, about 11 keel punctae in $10 \mu$.

Discussion: This species is similar to Nitzschia cylindrica, but differs by the structure of the apices and the homogeneous intercostal membranes.

Holotype: Plate 5, Figure 31; from DSDP Leg 18, Sample 173-29(CC), northeast Pacific, off northern California.

Paratype: Plate 26, Figures 3, 4; Plate 5, Figure 42(?).

Nitzschia sp. 2 Schrader

(Plate 5, Figures 16-18)

Description: Valves found only as fragments. Differs from Nitzschia heteropolica by the coarser structure, the different, more acute apex, and the distinct keel.

\section{Genus PINNULARIA Ehrenberg (1840)}

Species belonging to this genus were found sporadically at some sites. No attempts have been made to treat these systematically. All species found inhabit freshwater environments.

\section{Genus PSEUDOEUNOTIA Grunow in Van Heurck (1880)}

\section{Pseudoeunotia doliolus (Wallich) Grunow in Van Heurck (1880)} (Plate 4, Figures 1-8)

Description: Hustedt (1959), p. 258-260.

DSDP Leg 18 occurrences: This species is found in transitional to equatorial biocoenoses. Not found in arcto-boreal sediments.

\section{Genus PSEUDOPYXILLA Forti (1909) \\ Pseudopyxilla americana (Ehrenberg) Forti (1909) (Plate 10, Figure 22)}

Description: Forti (1909), p. 14, pl. 1, figs. 6-7; SheshukovaPoretskaya (1967), p. 227, pl. 39, fig. 2.

DSDP Leg 18 occurrences: These individuals represent spores of the genus Rhizosolenia.

Genus PYXILLA Greville (1865)

Pyxilla johnsoniana Greville (1865) (Plate 26, Figure 11)

Description: Forti (1909), pl. 2, figs. 3-4.

DSDP Leg 18 occurrences: Only a broken specimen could be observed.

\author{
Genus RAPHIDODISCUS Smith (1887) \\ Rhaphidodiscus marylandicus Christian (1887) \\ (Plate 22, Figure 7)
}

Description: Hanna (1932), p. 208-210, pl. 14, figs. 3-4.

Genus RHABDONEMA Kützing (1844)

Rhabdonema arcuatum (Agardh) Kützing (1844) forma ventricosa Cleve (1873)

Description: Hustedt (1959), p. 21, fig. 549 d.

DSDP Leg 18 occurrences: Found frequently within the Pleistocene sections at various sites. No illustration.

\section{Rhabdonema japonicum Brun et Tempere (1889) (Plate 12, Figure 10)}

Description: Sheshukova-Poretskaya (1967), p. 258-259, pl. XLIII, fig. 14 .

Genus RHAPHONEIS Ehrenberg (1844)

Rhaphoneis amphiceros Ehrenberg (1844)

(Plate 25, Figures 2, 3) 
Description: Hustedt (1959), p. 174, figs. 680-681.

Discussion: Only those specimens possessing finely punctate apices with one mucous pore at each apex situated excentric to the axial area are here included in $R$. amphiceros.

\section{Rhaphoneis angularis Lohmann (1938) \\ (Plate 26, Figures 9, 10)}

Description: Lohmann (1938), p. 92-93, pl. 22, figs. 6-8.

Discussion: Close to $R$. amphiceros but differs in the shape of the valves, the coarse areolation of the apices and the transpical striation over the entire valve. 173.

DSDP Leg 18 occurrences: Found in the Pliocene section at Site

\section{Rhaphoneis angustata Pantocsek (1903)}

Description: Sheshukova-Poretskaya (1967), p. 241-242, pl. 41 , fig. 8 ; pl. 43, fig. 2 .

DSDP Leg 18 occurrences: Found frequently in the Lower Pleistocene and Pliocene sections of Sites 173 and 178. No illustration.

\section{Rhaphoneis cocconeides Schrader nova species} (Plate 25, Figures 9, 10)

Description: Valve flat, broadly elliptical with broad rounded apices. Areolation coarse, transapical in the middle of the valve, radial near the apices, transapical striae 8 in $10 \mu$. Apices with an ovate area of small radiate areolae and one eccentric mucous pore at each side. Axial area small, lanceolate, hyaline, covered with a network of small indistinct ribs. Length $20 \mu$, breadth $12 \mu$

- Discussion: Resembles the raphe-lacking valve of Cocconeis species. Differs from Rhaphoneis amphiceros by the ribbed axial area.

Holotype: Plate 25, Figure 10; from DSDP Leg 18, Sample 173-3-6(56-57 cm), northeast Pacific, off northern California.

Paratype: Plate 25, Figure 9.

\section{Rhaphoneis margaritalimbata Mertz (1966) (Plate 25, Figure 13)}

Description: Mertz (1966), p. 27, pl. 6, figs. 1-3

DSDP Leg 18 occurrences: Found in varying abundance in the Pliocene sections of Sites 173 and 178 .

\section{Rhaphoneis miocenica Schrader nova species} (Plate 25, Figures 1, 11)

Synonym: Rhaphoneis amphiceros Ehrenberg of Hanna (1932), pl. 15, fig. 3-5.

Description: Valve flat, strongly silicified, $25-55 \mu$ long, $16-22 \mu$ in breadth, broadly lanceolate with broadly rounded or slightly acute apices. Areolation coarse, arranged in nearly apical lines about 7 in $10 \mu$, separated by hyaline bands, especially prominent near the marginal line. Areolae transapical, 7 in $10 \mu$, radial near the apices. Axial area distinct, narrow, with parallel margins. Transapical rows bordered by curved lines, on the inside of the valve forming a pearl-like band.

Discussion: Differs from Rhaphoneis amphiceros by the arrangement of the transapical rows, and by the absence of fine areolae area near the apices.

Holotype: Plate 25, Figure 1; from DSDP Leg 18, Sample 173-30(CC), northeast Pacific, off northern California.

Paratype: Plate 25, Figure 11

Rhaphoneis sachalinensis Sheshukova-Poretskaya (1967)

(Plate 23, Figure 20; Plate 25, Figures 5, 7, 8, 14-16)

Description: Sheshukova-Poretskaya (1967), p. 242, pl. 42 , fig. 2. Valves narrow, linear-lanceolate with slightly attenuated capitate poles; $40-50 \mu$ long, $7 \mu$ wide. Areolae coarse, circular, forming two marginal apical lines. Transapical rows 8 in $10 \mu$ in the middle of the valve, becoming radial towards the apices. Axial area wide, lanceolate.

\section{Rhaphoneis surirella (Ehrenberg) Grunow in Van Heurck (1880)} (Plate 25, Figures 4,6)
Description: Hustedt (1959), p. 173-174, fig. 679.

Genus RHIZOSOLENIA Ehrenberg (1841)

Rhizosolenia alata Brightwell (1858)

(Plate 10, Figure 12)

Description: Hustedt (1930), p. 600-604, figs. 345-348.

Rhizosolenia cf. alata Brightwell (1858)

(Plate 10, Figures 14-17, 23)

Discussion: Forms placed in this species are different from Rhizosolenia alata by the strongly silicifed frustules, by the round apical processes, and by the slit at the end of the apical process.

\section{Rhizosolenia barboi Brun (1894)}

(Plate 24, Figures 4, 7)

Synonym: Rhizosolenia curvirostris Jousé (partim); Rhizosolenia curvirostris var. inermis Jouse, 1971 , p. 15 fig. 2.

Description: Donahue (1970), p. 136.

Rhizosolenia bergonii $H$. Peragallo (1892)

(Plate 9, Figures 1-5, 7 8, 10, 12, 22, 23; Plate 10, Figures 24, 29)

Description: Hustedt (1930), p. 575-576, fig. 327.

Discussion: Differs from $R$. hebetata forma hiemalis by the morphology of the apical spine. The spine looks like an ampulla with a wide hollow chamber at the base, becoming narrowly elongated in the middle of the spine, and opening again at the top.

Rhizosolenia curvirostris Jousé (1968)

(Plate 24, Figures 5, 6, 8, 9)

Description: Donahue (1970), p. 135-136, fig. 6 .

Rhizosolenia hebetata (Bail.) Gran forma hiemalis Gran (1904) (Plate 9, Figures 11, 13-17, 19-21, 24, 25)

Description: Hustedt (1930), p. 590-592, fig. 337.

Rhizsolenica miocenica Schrader nova species (Plate 10, Figures 2-6, 9-11)

Description: Valve cylindrical, greatly widened at the base $70 \mu$ in diameter, tapering towards the apex, apical process round with radial punctate lines, about 20 in $10 \mu$, punctae forming oblique rows, distance between oblique rows little wider than radial rows. Apical process with apical spine at the top. Spine tapers toward the top, with a small central canal. Apical process with a hyaline strip markedly tapering at the top of the apex and continuing into spines.

Discussion: Identical with the Rhizsolenia sp. 2 SheshukovaPoretskaya (1967), p. 204, pl. 33, fig. 6.

Holotype: Plate 10, Figure 2; from DSDP Leg 18, Sample 173-19-2(55-56cm), northeast Pacific, off northern California.

Paratype: Plate 10, Figures 3-6, 9-11

\section{Rhizosolenia praealata Schrader nova species} (Plate 10, Figure 13)

Description: Valve cylindrical, valve moderately robust, with rows of radial punctae beginning at the base of the valve and ending in middle of apical process. Apical process without spines, round cylindrical, $10 \mu$ in diameter, hyaline. At the end of the cylindrical apical process, a slot projects deeply into the interior. A punctate area lies on one side of the top of the apical process.

Discussion: Differs from Rhizosolenia alata by the conical apical process, by the distinct slit and the robust valves. Complete valves are $100 \mu$ long and about $40 \mu$ wide at the base.

Holotype: Plate 10, Figure 13; from DSDP Leg 18, Sample $173-18-3(56-56 \mathrm{~cm})$, northeast Pacific, off northern California.

\section{Rhizosolenia praebarboi Schrader nova species (Plate 24, Figures 1-3)}

Description: Cells cylindrical with enlarged base. Valve apex hyaline, straight, strongly silicified, $6 \mu$ wide. Top of the apical process broadly rounded with few isolated punctae near the top. No apical spine. Complete valves are $170-190 \mu$ long. 
Discussion: This species differs from Rhizosolenia barboi and Rhiz. curvirostris by the broadly rounded tops of the apical process which is distinctly straighter.

Holotype: Plate 24, Figure 1; from DSDP Leg 18, Sample $173-22-1(10-11 \mathrm{~cm})$, northeast Pacific, off coast of northern California.

Paratype: Plate 24, Figures 2, 3.

Rhizosolenia praebergonii Muchina (1965)

(Plate 10, Figure 7; Plate 9, Figure 6)

Description: Koizumi (1968), p. 217, pl. 34, figs. 20, 21.

Rhizosolenia styliformis Brightwell (1858)

(Plate 10, Figures 1, 20, 21, 18, 19; Plate 9, Figure 9(?))

Description: Hustedt (1930), p. 584-588, figs. 333-335.

\section{Rhizosolenia sp. 1 Schrader}

(Plate 9, Figure 18)

Description: Similar to Rhizosolenia hebetata forma hiemalis except for the elongated spine in these forms. No complete valve has been observed.

\section{Rhizosolenia sp. 2 Schrader}

$$
\text { (Plate 10, Figure 25) }
$$

Description: Valve similar to Rhizosolenia alata, no spine, but differs in the much smaller apical process. No complete valve has been observed.

\section{Rhizosolenia sp. 3 Schrader}

(Plate 10, Figures 26, 27)

Description: Apical process with a long cylindrical apical spine, not widened so the central canal remains the same size over the length of the spine.

\section{Rhizosolenia sp. 4 Schrader}

(Plate 10, Figure 8)

Description: Similar to Rhizosolenia miocenica but different in the morphology of the top of the apical process, which bears numerous, small $1 \mu$-long spines.

Genus ROPERIA Grunow in Van Heurck (1881)

Roperia tesselata (Roper) Grunow in Van Heurck (1881)

$$
\text { (Plate 19, Figures 3, 4, 8, 9) }
$$

Description: Hustedt (1930), p. 523-524, fig. 297.

\section{Genus ROUXIA Brun et Héribaud (1893)}

Rouxia californica M. Peragallo in Tempere and Peragallo (1910)

$$
\text { (Plate 3, Figures 18-20, 22(?), 26) }
$$

Synonym: $R$. peragalli Brun et Héribaud, in Tempere and Peragallo (1910) p. 117. R. peragalli f. californica (M. Perag.) Sheshukova-Poretskaya (1967), p. 295.

Description: Hanna (1930) p. 186-188, pl. 14, figs. 6-7.

\section{Rouxia diploneides Schrader nova species} (Plate 3, Figures 24, 25)

Synonym: Navicula rouxioidea Sheshukova-Poretskaya (1967) (partim) p. 284, pl. XLVI, figs. 6a, 6b.

Description: Valves linear-oblong with broadly rostrate apices and with small transapical constriction at the middle of the valves; $30-42 \mu$ long, $6-7 \mu$ wide (in the middle of the constriction). Two rudimentary raphe bars widely separated and situated near the apices. Transapical striae $12-13$ in $10 \mu$, parallel in the middle of the valve, becoming radiate near the apices. Transapical striae crossed by one apical line parallel to the margin in the middle and surrounding the two raphe bars, expanding poleward. Axial area narrow. Valve structure isopolar.

Discussion: This species is included with confidence in the genus Rouxia because of its characteristic raphe structure and the arrangement of valve striation.
Holotype: Plate 3, Figures 24, 25; from DSDP Leg 18, Sample 173-25-3(55-56 cm), northeast Pacific, off northern California.

\section{Rouxia yabei Hanna (1930) \\ (Plate 3, Figures 21, 23)}

Synonyms: Rouxia peragalli f. yabei (Hanna) SheshukovaPoretskaya (1967) p. 295, pl. XLIII, fig. 18. Rouxia peragalli Brun et Héribaud, in Héribaud (1893) pl. 1, figs. 12b, 12c.

Description: Hanna (1930) p. 185 , pl. 15 , figs. 24 .

\section{Rouxia naviculoides Schrader nova species}

(Plate 3 Figures 27-32)

Synonyms: Rouxia peragalli Brun et Heribaud, in Tempere and Peragallo (1910) p. 117. Navicula rouxioidea Sheshukova-Poretskaya (1967) p. 284 (partim).

Description: Valves linear, with rounded cuneate apices or narrowly lanceolate with cuneate-obtuse apices; $30-15 \mu$ long, $6-8 \mu$ wide. Valve surface sometimes slightly convex with a central depression. Two rudimentary raphe bars separated by a narrow, 3-5 $\mu$ long axial area. Transapical striae $13-14$ in $10 \mu$, parallel, becoming radiate near the apices. Striae crossed by one apical line near the axial area. Transapical striae with 2-3 inner pores. Outer membrane homogeneous (in light microscope). Valve structure isopolar.

Discussion: Differs from Rouxia diploneides by the shape of the valves, the closely spaced raphe bars and by the finer structure. This species is included in the genus Rouxia because of the appearance of the two rudimentary raphe bars, and other structure, typical of the genus.

Holotype: Plate 3, Figure 30; from DSDP Leg 18, Sample 173-18-3(56-57 cm), northeast Pacific, off norhtern California.

Paratype: Plate 3, Figures 27-29, 31, 32.

\section{Rouxia peragalli Brun et Héribaud, in Héribaud (1893)}

Description: Hanna (1930) p. 180-184, pl. 14, figs. 1, 5. Some specimens resembling this species were found in the lower half of Hole 173. They resemble Rouxia yabei but differ in their structure (see Hanna's description).

DSDP Leg 18 occurrences: Found only as a few broken specimens in Hole 173. No illustration.

\section{Genus SURIRELLA Turpin (1828) \\ Surirella elegans Ehrenberg}

Description: Hustedt (1930), p. 440-441, figs. 858-859. Several specimens were found in terrigenous sequences. No illustration. Inhabits freshwater environment.

\section{Surirella spiralis Kützing}

Description: Hustedt (1930), p. 445-446, fig. 870. Several specimens were found in terrigenous sequences. No illustration. Inhabits freshwater environment.

$$
\text { Genus SYNEDRA Ehrenberg (1830) }
$$

\section{Synedra jouseana Sheshukova-Poretskaya (1962)}

(Plate 23, Figures 21-23, 25, 38)

Description: Sheshukova-Poretskaya (1967), p. 245. Valves narrow, lanceolate with widened middle parts; $29-172 \mu$ long, $6-11 \mu$ wide. Apices acute, transapical striae $12-13$ in $10 \mu$, having their origin in marginal pores of the same spacing. Striae in light microscope hyaline, projecting $2-3 \mu$ into the valve. Axial area very wide, lanceolate separated into three parts by two apical lines. These lines represent borders of an apical convex swelling of the hyaline axial area. Mucous pores are difficult to detect near the poles.

Discussion: No varieties have been separated. Only those specimens with apical swelling of the valve and the transapical hyaline lines derived from marginal pores have been identified as $S$. jouseana. 


\section{Genus STAURONEIS Ehrenberg (1843)}

Stauroneis phoenicenteron (Nitzsch) Ehrenberg (1843)

Description: Hustedt (1959), p. 766-770, fig. 1118.

DSDP Leg 18 occurrences: Found sporadically in sediments bearing freshwater material. No illustration.

\section{Genus STEPHANODISCUS Ehrenberg (1845)}

Stephandiscus astreae (Ehrenberg) Grunow (1880)

Description: Hustedt (1930), p. 368-370, fig. 193.

DSDP Leg 18 occurrences: Found at several sites together with other reworked and displaced freshwater diatoms. No illustration.

Stephanodiscus astreae (Ehrenberg) Grunow var. minutula (Kützing) Grunow in Van Heurck (1881) (Plate 13, Figures 19, 20)

Description: Hustedt (1930), p. 369-370, figs. 183d, 183e.

DSDP Leg 18 occurrences: Found in several sites together with other reworked or displaced freshwater diatoms. This species (like Melosira granulata) can be easily transported by wind and is strongly silicified.

\section{Genus STEPHANOPYXIS Ehrenberg (1844)}

Stephanopyxis californica Schrader nova species

(Plate 15, Figures 13-18; Plate 16, Figures 4, 13)

Description: Cells single, dimorphic; $25-40 \mu$ in diameter, about $24 \mu$ high. Upper valve cylindrical with numerous spines, mostly broken. Structure consists of hexagonal areolae, about 5 in $10 \mu$, in tangential rows. Lower valve coscinodiscoid with a high mantle and a depression in the center of the valve. Areolae hexagonal, in tangential rows, 6-7 in $10 \mu$. Near the center of the valve two to three isolated mucous pores, sometimes isolated "interstitial meshes" near the margin.

Discussion: No similar dimorphic species were found in the literature. Isolated lower valves may be sometimes identified as Thalassiosira. This species is different from Stephanopyxis dimorpha by the more or less flat lower valves, the high cylindrical upper valves, and the isolated scattered spines on the upper valves. It is different from Stephanopysis kulmii by its coarser areolation of the lower valves, and lack of the trumpet-like spines of $S$. kulmii.

Holotype: Plate 15, Figure 15; from DSDP Leg 18, Sample 173-4-3 $(55-56 \mathrm{~cm})$, northeast Pacific, off northern California.

Paratype: Plate 15, Figures 13, 14, 16, 17, 18 (lower valve); Plate 16, Figures 4 (lower valve), 13 (lower valve).

\section{Stephanopyxis dimorpha Schrader nova species}

(Plate 15, Figures 9-11, 19, 20; Plate 16, Figures 1-3, 8-11; Plate 24, Figure 10)

Description: Cells single, dimorphic, $30-50 \mu$ in diameter, about $20 \mu$ high. Upper valve flat, cylindrical, with $2-5$ spines centrally arranged. Valve margin with a thin hyaline edge. Areolae hexagonal, in tangential rows, areolae becoming gradually smaller away from the center of the valve, 5 in $10 \mu$ in the middle of the valve, 5-6 near the margin. Lower valve slightly convex with indented central part, 3-6 mucous pores near the center of the valve. Areolae hexagonal in tangential rows becoming gradually smaller toward the margin, $4-5$ in $10 \mu$.

Discussion: This species differs from all previously described Stephanopyxis species by the dimorphic cells. It differs from St. californica by the convex upper and lower valves and the arrangement of the central spines. Identification when only lower valve is found is simple: St. dimorpha has convex valves with gradually curved margins, $S$ t. californica has almost flat lower valves with abruptly curved margins.

Holotype: Plate 15, Figures 9-11; from DSDP Leg 18, Sample 173-1-4(114-115cm), northeast Pacific, off northern California.

Paratype: Plate 15, Figures 19, 20 (lower valves); Plate 16, Figures 1-3 (upper valves in girdle view), 8-11 (upper valves); Plate 24 , Figure 10 (lower valve).

Stephanopyxis kulmii Schrader nova species (Plate 15, Figures 8, 12; Plate 16, Figure 4)
Derivatio nominis: Dedicated to L.V. Kulm, Co-Chief Scientist DSDP Leg 18.

Description: Cells single, dimorphic; $16-19 \mu$ in diameter, about 13-15 $\mu$ high. Upper valve with numerous trumpet-like spines, arranged at some distance from the center. Spines have a wide central canal. Structure consists of hexagonal areolae, about 9 in $10 \mu$, gradually becoming smaller $(9-10$ in $10 \mu)$ towards the margin, in tangential rows. Lower valve convex with a slightly depressed center. Areolae hexagonal to circular, arranged in tangential rows, about 15 in $10 \mu$.

Discussion: Similar to Stephanopyxis californica but differs by the convex lower valve, the fine areolation of the lower valves, and the trumpet-like spines of the upper valve.

Holotype: Plate 15, Figure 12; from DSDP Leg 18, Sample 173-2-2(43-44cm), northeast Pacific, off northern California.

Paratype: Plate 15, figure 8; Plate 16, Figure 4 (lower valve).

Stephanopyxis turris (Grev, et Arn.) Ralfs in Pritchard (1861)
(Plate 15, Figures 1-7)

Description: Hustedt (1930), p. 304-307, figs. 140-144.

\section{Genus THALASSIONEMA Grunow (1881) \\ Thalassionema antiqua Schrader nova species (Plate 23, Figures 26-30)}

Description: Valves linear, sometimes constricted at the middle, with broadly rounded ends; $12-10 \mu$ long, about $5 \mu$ wide. Apices isopolar, at one apex a very short median spine sometimes visible. Axial area linear, narrow, about $2 \mu$ wide. Transapical striae about 11 in $10 \mu$, arising from a marginal pore. Striae transapical in the middle of the valve, radial at the apices.

Discussion: This species differs from $T$. nitzschioides by the small axial area and the elongate transapical structure which covers almost half of the valve.

Holotype: Plate 23, Figure 29, from DSDP Leg 18, Sample $178-54-2(26-27 \mathrm{~cm})$, from the Gulf of Alaska.

Paratype: Plate 23, Figures 16-18, 30.

\section{Thalassionema claviformis Schrader nova species} (Plate 23, Figures 11 15)

Derivatio nominis: clava (latin) $=$ club

Description: Valve club-like, heteropolar, narrow, linear; $15-45 \mu$ long, about $5 \mu$ wide. Apices heteropolar, one apex broadly rounded, the other more narrowly rounded with a small median spine. Axial area wide, lanceolate. One marginal line of punctae, about 11 in $10 \mu$. The marginal structure lies half on the valve surface and half on the valve mantle. This structure is crowned with an apical marginal line.

Discussion: This species differs from Thalassionema nitzschioides and $T$. hirosakiensis by the heteropolar valves and the finer marginal punctae.

Holotype: Plate 23, Figure 11; from DSDP Leg 18, Sample 173-23-2(55-56cm), northeast Pacific, off northern California.

Paratype: Plate 23, Figure 15.

Thalassionema hirosakiensis (Kanaya) nova comb. (Plate 23, Figures 31-33)

Synonym: Fragilaria hirosakiensis Kanaya (1959), p. 104-106, pl. 9 figs. 11-15.

Description: Kanaya (1959), p. 104-106, pl. 9, figs. 11-15.

Thalassionema lineatum Jousé (1971)

(Plate 23, Figure 14)

Description: Jousé (1971), p. 15-16, fig. 3 .

Discussion: This species resembles very closely Thalassionema nitzschioides but differs by the presence of two apical lines running through the middle of the hyaline valve from one apex to the other. The present specimens are different from Jousé's figured specimen in having a much finer marginal punctation; here 10 punctae in $10 \mu, T$. lineatum Jouse 6.8 in $10 \mu$. 
Thalassionema nitzschioides Grunow in Van Heurck (1881)

(Plate 23, Figures 2, 6, 8, 9, 10, 26, 29, 34 12-13 (aberrant forms, claviform))

Description: Hustedt (1959), p. 244-246 fig. 725; Hasle (1967), p. 111 , figs. $5,27-34,39-44$.

Discussion: No variations were distinguished.

\section{Thalassionema robusta Schrader nova species} (Plate 23, Figures 24, 35-37)

Description: Valves narrow, linear, lanceolate with broadly rounded apices; $55-60 \mu$ long, about $8 \mu$ wide. Apices isopolar, one apex with an obtuse median spine. Axial area wide, lanceolate. One marginal line of punctae, about 9 in $10 \mu$. The marginal structure lies half on the valve surface and half on the valve mantle. No other structure observed in the axial area, hyaline.

Discussion: This species differs from $T$. claviformis by its more heavily silicified frustules, the isopolar shape, the coarser structure; and from $T$. nitzschioides by the more heavily silicified frustules, the more rectangular punctae, and the coarser structure.

Holotype: Plate 23, Figure 24; from DSDP Leg 18, Sample 178-37-2(30-41), from the Gulf of Alaska.

Paratype: Plate 23, 35-37.

\section{Genus THALASSIOSIRA Cleve (1873)}

Thalassiosira antiqua (Grunow) Cleve in Cleve-Euler (1951-1955) (Plate 11 Figure 25, Plate 25, Figure 19)

Description: Sheshukova-Poretskaya (1967), p. 143-144, pl. 14, fig. 3.

\section{Thalassiosira convexa Muchina (1965)} (Plate 11, Figures 37, 38)

Synonym: Coscinodiscus muckhina (Muchina) Donahue (1970). Description: Donahue (1970), p. 136-137, pl. 3, figs. a-f.

Discussion: Donahue (1970) gives a geological range of Middle Miocene to Uppermost Pliocene for this species. There, however, is no evidence that this species occurs in Miocene sediments. It is a good Pliocene indicator and ranges back only into the late Late Miocene (Burckle 1972).

Thalassiosira decipiens (Grunow) Joergensen (1905)

(Plate 11, Figures 8, 9, 34-35(?); Plate 16, Figure 12(?))

Description: Hustedt (1930), p. 322323 , fig. 158; SheshukovaPoretskaya (1967), p. 141, pl. 14, fig. 2.

\section{Thalassiosira excentrica (Ehrenberg) Cleve (1903)}

(Plate 25, Figure 17; Plate 16, Figures 5 6)

Description: Sheshukova-Poretskaya (1967), p. 141-142, pl. 14 fig. 4 .

Discussion: This species was until now identified as Coscinodiscus excentricus, but I agree with Jouse and others in placing these forms in the genus Thalassiosira because they possess the following morphological characteristics: central strutted tubulus, marginal strutted tubuli, labiate process.

DSDP Leg 18 occurrences: Plate 25, Figure 17, Plate 16, Figures 5, 6 (Thalassiosira c.f. excentrica).

\section{Thalassiosira gravida Cleve (1896)}

(Plate 14, Figures 3-8)

Description: Hustedt (1930), p. 325-326, fig. 161; SheshukovaPoretskaya (1967), p 147-148, pl. 15, fig. 1.

\section{Thalassiosira nativa Sheshukova-Poretskaya (1964)} (Plate 11, Figures 23-24) fig. 7

Description: Sheshukova-Poretskaya (1967), p. 145, pl. 14,

Discussion: Included in this species is Thalassiosira spec. A of Burckle (1972). This species differs from Thalassiosira oestrupii by the numerous mucous pores in the middle of the valve which are similar in arrangement to those in Thalassiosira antiqua.
Thalassiosira nidulus (Tempère et Brun) Jousé (1961) (Plate 11, Figures 1-7)

Description: Sheshukova-Poretskaya (1967), p. 140-141, pl. 11, fig. 8 , p1. 14, fig. 1 .

Thalassiosira nordenskioeldii Cleve (1873) (Plate 14, Figures 9-12)

Description: Hustedt (1930), p. 321-322 fig. 157.

Thalassiosira oestrupii (Ostenfeld) Proskina-Lavrenko (1956)

(Plate 11, Figures 16-22, 26-33, 36, 39-45;

Plate 16, Figure 14; Plate 17, Figures 18, 19, 24, 25)

Description: Hustedt (1930), p. 318, fig. 155 as Coscinosira oestrupii.

Thalassiosira pacifica Gran and Angst (1931)

(Plate 25, Figures 18, 20, 21; Plate 14, Figures 13-14(?))

Description: Gran and Angst (1931). Identification of this species based upon illustrations presented by Jousé (1962), fig. 63.3 .

Thalassiosira praeconvexa Burckle (1972) (Plate 11, Figures 10-15)

Description: Burckle (1972), p. 242-242, pl. 2, fig. 7-9.

\section{Thalassiosira punctata Jouse (Plate 17, Figure 20)}

Description: Sheshukova-Poretskaya (1967) p. 151, pl. XIV, Fig. 10, pl. XVIII, Fig. 1.

\section{Thalassiosira usatchevii Jousé (1961)}

Description: Sheshukova-Poretskaya (1967), p. 150, pl. 15, fig. 3 .

DSDP Leg 18 occurrences: Rare in Pliocene-Miocene sediments from Site 173. No illustration.

\section{Thalassiosira zabelinae Jouse (1961) \\ (Plate 14, Figures 1, 2)}

Description: Sheshukova-Poretskaya (1967), p. 149, pl. 16, fig. 2 .

Discussion on Thalassiosira spec. 1-6: Only those Thalassiosira species which could be definitely determined have been treated systematically. All the following furms must be studied by electron-microscopy and compared with other Thalassiosira species before they can be accurately classified.

Thalassiosira sp. 1 Schrader

(Plate 14, Figures 15, 16)

Thalassiosira sp. 2 Schrader

(Plate 14, Figures 17, 18)

Thalassiosira sp. 3 Schrader

(Plate 14, Figures 19, 20)

Thalassiosira sp. 4 Schrader (Plate 14, Figure 21)

Thalassiosira sp. 5 Schrader

(Plate 17, Figures 16, 17)

Thalassiosira sp 6 Schrader (Plate 17, Figures 21-23)

Genus THALASSIOTHRIX Cleve et Grunow (1880)

Thalassiothrix frauenfeldii Grunow (1880)

Description: Hustedt (1959), p. 247-248 fig. 727; Hasle (1967), p. 113, figs. 10, 21 .

DSDP Leg 18 occurrences: Found in varying abundance in the upper part of Holes 173, 175, 176, 178. No illustration. 
Thalassiothrix longissima Cleve et Grunow (1880) (Plate 23, Figures 7, 17, 18)

Description: Hasle (1967), p. 114, fig. 20; Cupp (1943), p. 184, fig. 134 .

Thalassiothrix miocenica Schrader nova species (Plate 23, Figures 2-5)

Description: Mostly valves broken into fragments, but one complete specimen has been observed; $400 \mu$ long, $3 \mu$ wide in the middle of the valve. Marginal punctae 10 in $10 \mu$. The two valve ends are completely different. One end resembles the spinous end of Thalassiothrix longissima with two tongue-shaped projecting spines over the obtusely rounded apex. The other end suddenly widens and is here about $8 \mu$ in diameter. Punctae covering the whole margin of this apex. At the end of the apex one small spine projects from the valve surface, similar to the apex spine of Thalassionema nitzschioides.

Discussion: No similar species has been observed in the literature. It differs from Thalassiothrix longissima by the widened apex at one side and by the punctate margin.

Holotype: Plate 23. Figure 2; from DSDP Leg 18, Sample 173-25-1(95-96cm), northeast Pacific, off northern California.

Paratype: Plate 23, Figures 3-5 (Figure 5 represents an aberrant specimen with a small widening at the end).

\section{Genus TRACHYNEIS Cleve \\ Trachyneis aspera (Ehrenberg) Cleve}

Description: Hendey (1964) p. 236-237, numerous figures.

DSDP Leg 18 occurrences: Rare in the marine-littoral sequences. No illustration.

\section{Genus TRICERATIUM Ehrenberg (1941)}

Triceratium antediluvianum (Ehrenberg) Grunow (1870)

Description: Hustedt (1930), p. 810-812, fig. 472.

DSDP Leg 18 occurrences: Found sporadically in Pliocene and Miocene sediments. No illustration.

Triceratium antiquum Pantocsek (1886)

$$
\text { (Plate 20, Figure 5) }
$$

Description: Azpeitia (1911), p. 221, pl. 12, fig. 2.

Triceratium cinnamomeum Greville (1863) (Plate 12, Figure 8)

Discussion: The correct taxonomic position of the forms which are here assigned to Triceratium cinnamomeum seems doubtful as this species occurs only in Miocene sediments and $T$. cinnamomeum is a living equatorial Pacific species.

Triceratium condecorum Brightwell (1853)

(Plate 12, Figure 9)

Description: Hanna (1932), p. 221, pl. 17, figs. 1, 3.

Triceratium sp. 1 Schrader

(Plate 12, Figures 12, 16)

Discussion: No equivalent has been found in the literature up to now. But as the taxonomy of the genus Triceratium is at the moment problematic, no new taxa are described.

\section{Genus TROCHOSIRA Kitton (1870-1871)}

Trochosira concava Sheshukova-Poretskaya (1967)

(Plate 12, Figures 13, 14)

Description: Sheshukova-Poretskaya (1967), p. 138, pl. 11, fig. 7 ; pl. 13, fig. 3 .

Discussion: Assignment of these forms to $T$. concava is problematic and needs revision.

Trochosira spinosa Kitton (1870-1871)

(Plate 12, Figures 18, 19)
Description: Sheshukova-Poretskaya (1967), p. 137-138, pl. 11, fig. $6 ;$ pl. 13 , fig. 4 .

\section{Genus et species indet. 1 Schrader (Plate 20, Figure 8)}

Description: Valve round with radial structure and hyaline sectors in between the rows. No similar species could be found in the literature. The systematic position can not yet be determined.

Genus et species indet. 2 Schrader

(Plate 12, Figures 1-6)

Description: Valve ovate with two obtuse rounded processes inclined at different angles. Structura radial. No similar species has been found in the literature. The systematic position can not yet be determined.

Genus et species indet. 3 Schrader

(Plate 6, Figures 7-9, 20-22)

Description: Valve round with a tangential plication and a chambered margin. These individuals are close to the Coscinodiscus plicatus Group but differ by the chambered margin. No similar species could be observed in the literature. The systematic position has not yet been determined.

\section{PALEOCLIMATIC INTERPRETATION}

Climatic fluctuations as revealed by diatom floras have been studied for the Holocene to Pliocene interval. The mean surface circulation in the North Pacific is wind driven. Four distinct regions have been defined (Figure 30), (1) the subarctic Pacific, (2) the transitional North Pacific, (3) the east-central-north Pacific and (4) the Pacific equatorial region (Kanaya and Koizumi, 1966). These regions could be defined by specific diatom thanatocoenoses (Jous'e, 1971; Kanaya and Koizumi, 1966). The great influence of the Subarctic Current and the North Pacific Current on the general distribution of diatom biofacies has been pointed out by Donahue (1970). These current systems have shifted north and south in the Pleistocene, preventing direct correlation of $\mathrm{Td}$ curves with continental Pleistocene stages.

\section{Site 173 (Figure 10)}

Two hundred individuals were counted from each sample at Site 173 to detect paleoclimatic oscillations. Ratios between cool- and warm-water indicators were calculated. Warm-water species were Pseudoeunotia doliolus, Nitzschia fossilis, N. marina, N. reinholdii, Thalassiosira oestrupii, Hemidiscus cuneiformis, Ethmodiscus rex, and Rhizosolenia bergonii. Cool-water species were Denticula seminae, Coscinodiscus marginatus, Thalassiothrix longissima, Denticula kamtschatica, Rhizosolenia curvirostris, and Rhizosolenia barboi.

Four major warmer periods are shown within the Pleistocene section at (a) 173-1-1(119-120 cm), (b) 173-3-4(109-110 cm), (c) $1736-1(105-106 \mathrm{~cm})$, and (d) $173-7-2(55-56 \mathrm{~cm})$. Several other more temperate periods lie within the warmer periods. But they reach $\mathrm{Td}$ values of not more than 20. A strong warming takes place over the Pleistocene-Pliocene boundary and is one criterion for placing the boundary at $1738-5(55-56 \mathrm{~cm}$ ) (where extinctions and first occurrences of tropical species could be used to define this boundary in temperate to cool biofacies).

One strong warmer period was seen within the Pliocene section from $173-11-4(55-56 \mathrm{~cm})$ to $173-12-5(63-64 \mathrm{~cm})$. 
Three temperate periods were detected within the late Pliocene at $173-9-6(55-56 \mathrm{~cm})$, at $173-10-1(55-56 \mathrm{~cm})$, and at $173104(55-56 \mathrm{~cm})$. An increase of the Td values took place in the Early Pliocene and reached its maximum at the Pliocene-Miocene boundary. Several warmer and cooler assemblages were found in the Miocene sequence, but results are not yet complete.

\section{Site 175 (Figure 14)}

Two hundred individuals were counted from each sample at Site 175 to detect paleoclimatic oscillations. Ratios between cool- and warm water indicators were calculated. Warm-water species were Pseudoeunotia doliolus, Nitzschia marina, Thalassiosira oestrupii, and Thalassionema nitzschioides. Cool-water species were Thalassiothrix longissima, Rhizosolenia curvirostris, Denticula seminae, and Coscinodiscus marginatus.

Three major periods of cooling within the Upper and Middle Pleistocene are represented at (a) 76 meters (175-9.4, 78.79 cm), (b) 100 meters $(185-11, \mathrm{CC})$ and (c) 147 meters $(175-17-2,68-69 \mathrm{~cm})$. Several other more temperate coolings are recognized at 32 merers, 56 meters, and 186 meters below the sea floor. The cooling at 10 meters may represent the Holocene-Pleistocene boundary.

Only one Rhabdonema arcuatum Zone (Figures 33 and 34) could be seen within the NPD Zone II at 81 meters $(175.9, \mathrm{CC})$; this occurrence corresponds to a period of extensive inerstadial rise in temperature (Jousé, 1971).

Diatom thantocoenoses belong to the recurrent diatom groups II and IV which represent the Northeast Transitional Diatom Assemblage (North) of Kanaya and Koizumi (1966) in the upper part of the hole (Denticula seminae $>10 \%$ of the whole assemblage), and the Northeast Transitional Diatom Assemblage (South) in the lower part of the hole (D. seminae $<10 \%$ of the whole assemblage).

\section{Site 176}

The marine pelagic diatom thantocoenoses represent the Northeast Transitional Diatom Assemblage (North) of Kanaya and Koizumi (1966).

No detailed paleoclimatological investigation could be carried out because the lack of indicator species.

\section{Site 177 (Holes 177 and 177A) (Figure 18)}

Two hundred individuals were counted from each diatom-bearing sample at Site 177 to detect paleoclimatic oscillations. Ratios between cool-water indicators (Thalassiothrix longissima, Denticula seminae, and Coscinodiscus marginatus) and warm to temperate-water indicators (Thalassionema nitzschioides and Thalassiosira oestrupii) were calculated. Generally speaking, the diatom flora indicates a progressive cooling with time from Holocene to Upper Pliocene. Four major cool periods could be seen within the section at (a) $177 \mathrm{~A}-1-1(65-66 \mathrm{~cm})$, (b) 177A-5(CC) and (c) 177A-8-2(65-67 cm) and 177A$11-2(65.67 \mathrm{~cm})$.

Rhabdonema arcuatum Zones were detected (Figures 33 and 34$)$ at (a) $177 \mathrm{~A}-4-3(65-67 \mathrm{~cm})$ to $177 \mathrm{~A}-4-5(64-66 \mathrm{~cm})$ and at $177 \mathrm{~A}-11-3(69-71 \mathrm{~cm})$. These zones are equivalent to the warmer assemblages and occur within them. No Rhabdonema arcuatum Zone could be detected within NPD
Zone I, perhaps due to the sampling procedure and/or the core recovery.

The diatom thanatocoenoses belong to the recurrent diatom groups II and IV which represent the North Transitional Diatom Assemblage (North and South) of Kanaya and Koizumi (1966).

\section{Site 178 (Figure 20)}

Two hundred individuals were counted from each diatom-bearing sample at Site 178 to detect paleoclimatic oscillations. Td values for temperate-water biofacies were plotted using, as indicator species for cold water, Denticula seminae, Thalassiosira antiqua, Coscinodiscus marginatus, Rhizosolenia hebetata forma hiemalis, Rhizosolenia curvirostris, Rhizosolenia barboi, and Thalassiothrix longissima; and, for temperate to warm water, Thalassionema nitzschioides, Thalassiosira pacifica, Thalassiosira oestrupii, Rhabdonema arcuatum forma ventricosa, Rhizosolenia styliformis, and Coscinodiscus radiatus.

The Td shifts are not as marked as those found in the more southern holes. Five periods of relatively warmer surface water conditions are revealed at (a) 48 meters, (b) 75 meters, (c) 98 meters, (d) 105 meters and (e) 135 meters below the sea floor. These warmer periods of surface water correlate well with the occurrence of the Rhabdonema arcuatum Zone. This zone was found at $178-2(\mathrm{CC})$, at $178-9-3(100-102 \mathrm{~cm}$ ), and at 178-11(CC). (Figures 33 and 34). Detailed paleoclimatic studies in the interval from 390 to 746 meters could not be made because the lack of indicator species.

\section{Site 179 (Figure 22)}

Two hundred individuals were counted from each diatom-bearing sample at Site 179 to detect paleoclimatic oscillations. Td values for temperature indices were plotted using, as indicators for cool water, Denticula seminae, Thalassiosira antiqua, Thalassiothrix longissima, Rhizosolenia hebetata forma hiemalis, Coscinodiscus marginatus, Actinocyclus divisus, Actinocyclus ochotensis and A. oculatus; and, for temperate water, Thalassiosira oestrupii, Rhabdonema arcuatum forma ventricosa, Thalassiosira pacifica (Jousé, 1971), and Coscinodiscus radiatus. The climatic fluctuations on the diagram are caused by small changes in the relative frequency of warm- and cold-water diatom groups. These Td shifts reflect changes in the temperature of the subarctic surface water, but are quite different from those found at Sites 173, 175, 176, and 177; they are not as marked as seen at those sites which were influenced by the subarctic current shifts.

Four periods of warmer surface water conditions could be seen and they do correlate well with the Rhabdonema arcuatum Zones. These periods are represented by Samples 179-2-5(93-95 cm), 179-4-1(118-120 cm), 179-4(CC), and 179-6-2(35-37 cm) (Figures 33 and 34).

\section{Site 180 (Figure 24)}

One hundred individuals were counted from each diatom-bearing sample at Site 180 to detect paleoclimatic oscillations. Td values were plotted using the same indicator species for temperate- and cold-water assemblages as at Site 179. There are only a few oscillations. One occurs within 
the upper part of Core 1 and may indicate the Pleistocene-Holocene boundary. Three other warmer periods were found at 252 meters (180-15, CC), 280 meters $(180-184,93-95 \mathrm{~cm}$ to $180-18, \mathrm{CC})$ and 420 meters (180-20-4, 86-88 cm).

The Td shifts are relatively small compared to the more southern holes. Jous'e (1971) correlates the Rhabdonema arcuatum Zone within the NPD Zone I with a "period of extensive interstadial rise in temperature, which according to American data developed 24-28 thousand years ago within the Wisconsin glacial epoch (Flint, 1965)". On the other hand, Donahue (1970) could not find any rise in the Td values in core Vema 20-119 at a level from 79 to $99 \mathrm{~cm}$, where Jouse' (1971) reported that the Rhabdonema arcuatum Zone occurs. Here, two Rhabdonema arcuatum Zones were found at 252 meters (180-15 CC) and at 280 meters (180-18 CC) which correlate well with the peaks in the Td curves (Figures 33 and 34).

\section{Site 181}

No detailed study on the $\mathrm{Td}$ values was carried out. No Rhabdonema arcuatum Zone was detected. This may be attributable to sampling procedure or to core recovery.

\section{Site 182}

No detailed study on the Td values were carried out. One Rhabdonema arcuatum Zone was found in the NPD Zone II at 64.9 meters (182-3-1, 53-55 cm) (Figures 33 and 34).

\section{Correlation of the Td curves with other results}

Td values have been presented by Kanaya and Koizumi (1966) and Donahue (1970). The exact correlation of Td values can only be carried out if the same indicator species and the same preparation and counting methods have been used. However, general trends of warm, temperate, and cold biofacies ( $\mathrm{Td}$ values $50-100$ indicating warm biofacies, $\mathrm{Td}$ values 20-50 temperate biofacies, and $\mathrm{Td}$ values $0-20$ cold biofacies) can be revealed even if different indicator species have been used.

Td values for the more southern holes correlate with the results presented by Donahue (1970) for the HolocenePleistocene interval. Results are summarized in Figure 31 for Sites 173, 175, and 177 and for Lamont-Doherty Geological Observatory core RC 10-203.

A correlation of $\mathrm{Td}$ curves of core material taken north of $45^{\circ} \mathrm{N}$ latitude is difficult because the lack of good reference curves. The difference becomes clear in Figure 32. These differences are caused by the different interpretation of temperate- and cold-water species. Here, the results of Jousé (1971) have been used.

Site 176 correlates well with RC 10-203 (see Figure 31). Interpretation of results at Site 179 are difficult because of the spacing of samples and the lower sedimentation rate. The two peaks of the Td curves at Site 180 correlate with the first Rhabdonema arcuatum Zone which represents the first period of higher surface water temperature within NPD Zone I (see following section).
Correlation and Comments on Rhabdonema Arcuatum Zones

Rhabdonema arcuatum forma ventricosa Cleve occurred at various sites at distinct levels. Jousé (1971) found this species occurring within her Diatom Horizon II which correlates with the lower part of NPD Zone I. She found this zone in most of her North Pacific cores collected north of $40^{\circ} \mathrm{N}$ latitude. "This layer separates Horizon $\mathrm{II}$ in almost two equal halves and seems to correspond with a period of extensive interstadial rise in temperature (Formdel interstadial)". Jous'e correlates this horizon with the interstadial rise which occurred within the Wisconsin Glacial epoch which developed 24 to 28 thousand years ago.

Data from this study (Figure 33) reveal at least two Rhabdonema arcuatum Zones within NPD Zone I (ranging from 0-0.26 m.y. B.P.) and three zones within NPD Zone II (ranging from $0.26-0.92$ m.y. B.P.). These zones correlate with higher Td values as revealed by Donahue (1970) in Lamont-Doherty Geological Observatory cores V 20-108 and RC 10-203. They occurred at the approximate time intervals of (a) 50 to $100000 \mathrm{y}$. B.P., (b) 170 to $200,000 \mathrm{y}$. B.P., (c) 450 to 500,000 y. B.P., (d) 650 to 700,000 y B.P., and (e) 810 to 900,000 y. B.P. A complete sequence (Figure 34) of Rhabdonema arcuatum Zones was found at Site 179. Other sites lack several zones. This may be caused by the sampling procedure or by incomplete core recovery.

The Rhabdonema arcuatum Zone found in LamontDoherty Geological Observatory core V 20-119 (at 79-99 $\mathrm{cm}$, Jous'e, 1971) cannot be correlated with the above mentioned interstadial but falls within the Rhabdonema arcuatum Zone 1 (assuming a sedimentation rate of about 1 $\mathrm{cm} / 10^{3} \mathrm{y}$ [Donahue, 1970] and referring to the data presented by Jous'e, 1971). Donahue (1970) did not report a rise in temperature at this level, but this can be attributed to different interpretations of temperate- and cold-water indicator species.

Hustedt (1930) pointed out that Rhabdonema arcuatum forma ventricosa is a marine-littoral species which lives attached to a substratum. Here Rhabdonema arcuatum was found to occur within a pure pelagic marine diatom oozes and so appears to have lived at times as a marine planktonic species.

\section{SEDIMENTOLOGICAL INTERPRETATION}

Sedimentation rates calculated on the basis of the diatom zonation (Figures 35, 36) show three different regimes. Sites $173,176,177$, and 179 have a "lower" sedimentation rate of about 20 to $70 \mathrm{~m} / \mathrm{m}$.y. whereas Sites 175,178 , and 181 have a "medium" rate of sedimentation of 120 to $200 \mathrm{~m} / \mathrm{m} . \mathrm{y}$., and the highest sedimentation rate was found at Site 180 where a minimum rate of 1700 $\mathrm{m} / \mathrm{m}$.y. was calculated. These sedimentation rates correlate with the amounts of pelagic and hemipelagic terrigenous sediments; the higher the proportions of these sediment types, the lower the sedimentation rates.

The abundance of diatoms within a sample indicates the amount of dilution by terrigenous material, assuming a more or less constant production and sedimentation of pelagic organic skeletal debris. Jous'e (1971) pointed out that horizons rich in diatoms correspond to periods of 
warmer climate where the productivity of diatoms should not have been reduced. This coincides with the results obtained here. Whether a change in number of diatoms per given sediment volume indicates a reduction in productivity during cold periods or dilution of frustules by terrigenous material (with the same productivity) is difficult to decide. The latter explanation seems more reasonable. Pure diatom oozes with characteristic cold-water assemblages have been found within sequences of muds barren of diatoms, muds with rare diatoms, and muds rich in diatoms.

\section{Site 173}

Site 173 was cored at an actual water depth of 2927 meters below sea level. Evidence suggesting that this level was constant during Pleistocene and Late to Middle Pliocene time consists of nearly equal amounts of terrigenous material, displaced shallow-water diatoms (Triceratium montereyi, Diploneis smithii, Navicula lyra, Navicula praetexta, Arachnoidiscus sp., Isthmia nervosa, and Opephora sp.), and displaced freshwater diatoms (Melosira granulata, Stephanopyxis astreae, Cyclotella sp., Cymbella mexicana, Surirella sp.).

During Miocene time, the amount of displaced material is negligible. No littoral-marine, or freshwater forms could be detected within the interval from 130 meters to 265 meters below the sea floor. One explanation could be the subsidence of this portion of the margin during Early Miocene time, allowing deposition of biogenous sediments some distance from the Miocene strandline.

A marked littoral flora was found at 173-31-1, 132-134 $\mathrm{cm}$ with frequent Rhaphoneis miocenica, Melosira sulcata, and masses of sponge spicules These occurrences indicate a shallow-water (0-500 meters) depositional environment (Schrader, 1972).

Displaced Pleistocene species (Rhizosolenia barboi, Actinocyclus ochotensis) were found in the interval 280 to 320 meters below the surface. They are probably displaced from younger sediments by the coring procedure.

\section{Site 174 (Holes 174 and 174A)}

"Concretions" were found throughout the hole. They were flat discs, 50 to $100 \mu$ in diameter, which resisted the acid cleaning procedure. These "concretions" are most significant in Sample 174A-32(CC) and contain masses of broken sponge spicules, silt, and clay grains (1-20 $\mu$ in diameter) and freshwater diatoms (Melosira granulata). These "concretions" seem to be fecal pellets of animals living in a shallow water environment.

Displaced freshwater diatoms (including Melosira granulata, Stephanodiscus astreae, Surirella elegans, Cymbella mexicana, Epithemia turgida, Pinnularia microstauron, Eunotica sp., Gomphonema sp.) and displaced marinelittoral species (including Isthmia nervosa) were found sporadically throughout the hole. Reworked older fossils were found only in 174A-39(CC) (Leudugeria janischii, Endictya sp.).

All reworked thanatocoenoses were strongly affected by chemical and mechanical factors. Only heavily silicified tests are present. The sequence from 0 to 284 meters below the surface differs in abundance rather than diatom floral composition from that of 285 to 879 meters. This indicates a change in the depositional mechanism rather than a climatic change.

\section{Site $\mathbf{1 7 5}$}

Site 175 was cored at an actual water depth of 1999 meters below the sea level. During the whole Upper Middle Pleistocene the admixture of displaced marine-littoral diatoms (Trachyneis aspera, 175-1, CC; Triceratium antediluvianum, 175 1, CC, 175-2, CC; Arachnoidiscus indicus (?), 175-2, CC, 175-7, CC, 175-12, CC; Navicula praetexta, 175-2, CC; Isthmia nervosa, 175-7, CC; Biddulphia tuomeyi, 175-9, CC, 175-10, CC; Navicula hennedyi, 175-10, CC) was almost constant as was the admixture of freshwater species (Melosira granulata, sporadically in all samples, Cyclotella, 175-6, CC; Stephanodiscus astreae, 175-8-2, 86-87 cm, 175-17-3, 93-94 $\mathrm{cm}, 175-18-1$, 65-66 cm, 175-18-2, 65-66 cm; Epithemia turgida $175-3-2,71-72 \mathrm{~cm}, 1758-2,86-87 \mathrm{~cm}, 175-10-4$, $78-79 \mathrm{~cm}, 175-11-4,80-81 \mathrm{~cm}, 175-18-3,65-66 \mathrm{~cm})$.

A few reworked older fossils (Rhizosolenia barboi, Denticula hyalina, Denticula lauta, Nitzschia fossilis, and Rouxia californica) were found within the Pleistocene sequence (for more details see Table 2).

\section{Site 176}

Site 176 was drilled at a water depth of 193 meters. Displaced freshwater species were found sporadically in the upper part of the hole (Cymbella mexicana, 176-1, CC; Stauroneis phoenicenteron, 176-1, CC; Cymatopleura elliptica, 176-2, CC; Stephanodiscus astreae, 176-2, CC; Epithemia turgida, Surirella elegans, S. spiralis, 176-2, CC; Melosira granulata, in all samples). This freshwater thanatocoenoses is quite different from that found at Site 175. Here, a more lacustrine floral assemblage is present, whereas at Site 175 a more fluviatile assemblage was encountered.

Displaced marine-littoral species are Arachnoidiscus indicus (?), Isthmia nervosa, Triceratium montereyi. Biddulphia tuomeyi, Rhabdonema sp., Navicula hennedyii (176-1, CC, to 176-3, CC).

The decrease in number and preservation of tests with depth seems to be related to dissolution of opaline skeletons rather than to dilution by terrigenous material; thick-walled tests increase with depth while fine-shelled tests decrease (Schrader, 1972). The ratio (Figure 9) between autochthonous and allochthonous species shows the dissolution effect.

\section{Site 177 (Holes 177 and 177A)}

Site 177 was drilled at an actual water depth of 2006 meters below sea level. There are no indications based on diatoms or sponge spicules of tectonic movements at this site.

A nearly equal amount of displaced freshwater diatoms (including Melosira granulata, Stephanodiscus astreae, and Cyclotella meneghiana) occurs sporadically. These forms are small in diameter and could easily be transported by wind into this depositional environment. Displaced marine-littoral diatoms (including Trachyneis espera 177A-5-1, 64-66 cm and Navicula lyra $177 \mathrm{~A}-4-5,64-66 \mathrm{~cm}$ ) were also found sporadically. 
Reworked older microfossils, including Denticula hustedtii, D. kamtschatica, Actinocyclus ingens, Rhaphoneis angustata, and Coscinodiscus vetustissimus, were found in several samples (for more details see Table 3).

\section{Site 178}

Site 178 was drilled at an actual water depth of 4218 meters below the sea level. Sand, silt, and mud turbidites with intercalated intervals of diatom-rich muds and diatom oozes were penetrated for 795.4 meters in the northern part of the Alaskan Abyssal Plain.

A few older reworked microfossils (Actinocyclus ingens) were found in Sample 178-32-3(41-43 cm).

Diatom species of freshwater origin were found throughout the hole in small numbers, mostly Melosira granulata. Attempts to find evidence of enrichment of freshwater diatoms within the diatom-barren muds failed. Displaced marine-littoral diatoms (including Cocconeis sp., Rhabdonema sp., Actinoptychus undulatus) were found sporadically.

Strong dissolution of opaline tests was found in the sequence from 289 to 749 meters. Within the same sequence, bioturbation was abundant. A pure Coscinodiscus marginatus and Coscinodiscus marginatus forma fossilis ooze was found in the same intervals. Most of the Coscinodiscus marginatus frustules had been broken into pieces ard showed corrosion on the valve surface. The reduction to small pieces of this strongly silicified test can be explained by bioturbation (many burrow relicts occur in this section). The preservation and diatom floral composition of assemblages from burrow fillings differs from that of surrounding pelagic sediment, which illustrates the dissolution effect resulting from less exchange of water because of better compaction and smaller grain size inside burrows.

Coscinodiscus marginatus is one of the most common diatom species found in temperate and cold diatom assemblages of the North Pacific. Pure accumulations of this species have been reported by Jouse (1961). A mass development of $C$. marginatus in the Far East is reported to occur between Early and Late Miocene. Kanaya (1959) also mentions a mass occurrence (more than $50 \%$ of the diatom assemblage) and abundance in a few samples containing Assemblage C of Kanaya, Shinzan Area, Section No. 8, N. 10 upper part of Middle Miocene. In all these sections, weakly silicified diatom frustules are rare or absent. This fact shows that the enrichment of Coscinodiscus marginatus is not so much related to mass production of this species as to a varying dissolution of opaline skeletons at the sediment-water interface. The degree of dissolution is controlled by primary productivity, by deep currents, and by the chemistry of the sediment-water interface. A change of these conditions took place at Site 178 within the Middle Pliocene.

\section{Site 179}

Site 179 was drilled at an actual water depth of 3781 meters below sea level. Within sedimentological Unit 1 (0-16 meters) a completely reworked Lower Pliocene to Miocene section is present $(179-2-2,120-122 \mathrm{~cm}$ to
$179.2-4,68-70 \mathrm{~cm})$ with Actinocyclus ingens, Denticula kamtschatica, Rhizosolenia barboi, Rouxia diploneides, and Mediaria splendida.

No diatoms of freshwater or marine-littoral origin were encountered.

\section{Site 180}

Site 180 was drilled at an actual water depth of 4923 meters below sea level. Within sedimentological Units 1 and $2(0-240 \mathrm{~m})$ the abundance of pelagic material is very low in recovered intervals. Biogenous sequences become more abundant in Units 3 and 4 . Within these units the amount of displaced marine-littoral diatoms is generally low, but at times (180-15, CC; $180-18-4,93-95 \mathrm{~cm})$, a few individuals were found.

A mass occurrence of sponge spicules was found to occur at 93 meters $(180-10$, CC). This can only be explained by displacement from shallow water to this oceanic depth by turbidity currents; it corresponds with an increase in marine-littoral diatoms at this level.

\section{ACKNOWLEDGMENTS}

This investigation was supported by the Deutsche Forschungsgemeinschaft and by the U.S. National Science Foundation through the Deep Sea Drilling Project. Frau Prokopek and Frl. Röcker prepared most of the microscope slides and made the abundance counts. Frau Letzering and Herr Pede assisted in drawing and photographic work. Typing and proofreading was performed by Frau Schmidtmann, Frau Prokopek, and my wife. I thank Prof. Seibold for help and encouragement during this investigation and Dr. Burckle, Dr. Koizumi, and Dr. Simonsen for most fruitful discussions and assistance in taxonomic and stratigraphic questions and for supplying the author with rare literature and Lamont-Doherty Geological Observatory core material from equatorial and North Pacific sections.

Dr. Ingle and Dr. Kling read the manuscript and improved the English text.

\section{REFERENCES}

Abdel-Monem, A., Watkins, N. D. and Gast, P. W., 1971. Potassium-argon ages, volcanic stratigraphy, and paleomagnetic polarity history of the Canary Islands: Lanzarotte, Fuerteventura, Gran Canaria, and La Gomera. Am. J. Sci. 271, 490.

Agardh, C. A., 1824. Systema Algarum. Adumbravit C. A. Agardh. Literis Berlingianis, (Lundae) XXVII, $312 \mathrm{p}$.

, 1830. Conspectus criticus Diatomacearum. (Lundae). (1), 1

(Lundae). (4), 48

Azpeitia, D. F. Moros, 1911. La Diatomologia Espanola en los Comienzos des Siglo XX. Assoc. espanola para el progreso de las ciencias, Congr. de Zaragoza. 4. 320 p.

Bailey, J. W., 1854. Notes on new species and localities of microscopical organisms. Smithsonian Contrib. Knowledge. $7.16 \mathrm{p}$.

Bandy, O. L. and Ingle, J. C., Jr., 1970. Neogene planktonic events and radiometric scale, California. Geol. Soc. Am. Spec. Paper 124, 131.

Baumann, P. and Roth, P. H., 1969. Zonierung des Obereozäns und Oligozäns des Monte Cagnero (Zentralappenin) mit planktonischen Foraminiferen und Nannoplankton. Eclog. Geol. Helvet. 62, 303. 
Berggren, W. A., 1969. Cenozoic chronostratigraphy, planktonic foraminiferal zonation and the radiometric time scale. Nature. 224 (5224), 1072.

1972. A cenozoic time scale-some implications for regional geology and paleobiogeography. Lethaia. 5 195.

Blow, W. H., 1969. Late middle Eocene to recent planktonic foraminiferal biostratigraphy. Proc. First Intern. Conf. Planktonic Microfossils. Leiden. 1, 199.

Bolli, H., 1957. Planktonic foraminifera from the Oligocene-Miocene Cipero and Lengua Formations of Trinidad, B.W.I. In H. R. Loeblich, Jr., et al., Studies in Foraminifera. Bull. Nat. Museum.215, 97.

Bory, S. E. de, 1824. Encyclop. Meth. d'Hist. Nat. 2.

Bramlette, M. N. and Wilcoxon, J.A., 1967. Middle Tertiary calcareous nannoplankton of the Cipero section, Trinidad, B.W.I. Tulane Studies Geol. 5 (3), 93.

Brebisson, A. de and Godey, 1838. Consid'erations sur les Diatomees et essai d'une classification des genres et des espèces appartenant à cette famille. (Falaise). $20 \mathrm{p}$.

Brightwell, T., 1853. On the genus Triceratium with description and figures of the species. Quart. J. Micros. Sci. 1, 245.

1858. Remarks on the genus "Rhizosolenia" of Ehrenberg. Quart. J. Micros. Sci. 6, 93.

Brun, J., 1891. Diatom'ees esp'eces nouvelles marines, fossiles ou pelagiques. Mém. Soc. Phys. d'Hist. Nat. Genève. 31(1), 1.

1894. Espèces nouvelles. Le Diatomiste. London, Paris, Berlin. 2 (16), 72.

- 1895. Diatomées lacustres, marines ou fossiles. Le Diatomiste. 2, 14. 229.

Brun, J. and Héribaud, J., 1893. Les Diatomées d'Auvergne. Libraire des Sciences Naturelles. Paris. 1.

Brun, J. and Tempère, J., 1889. Diatomées Fossiles du Japan. Especes Marines et Nouvelles des Calcaires Argileux de Sandai et de Yendo. Mém. Soc. Phys. d'Hist. Nat. Genève. 30 (9).

Burckle, L. H., 1969. Late Cenozoic planktonic diatom zones in equatorial Pacific sediments (abstr.). Geol. Soc. Am. Abs. 1969. (7), 24.

1971. Correlation of late Cenozoic marine sections in Japan and the Equatorial Pacific. Trans. Proc. Paleont. Soc. Japan. N. S. 82, 117.

1972. Late Cenozoic planktonic diatom zones from the eastern equatorial Pacific. Nova Hedwigia, Beihft. 39, 217.

Castracane, D. A., 1875. Contribuzione alla florula delle Diatomee del Mediterraneo ossia esame del contenuta dello stomaco di una Salpa pinnata, pescata a Méssina. Atti. Acad. Pontif. dei nuovi Lincei. 28, 377.

1886. The voyage of H.M.S. Challenger. Report on the Diatomacae. Botany 2(I-III), 1. Edinburgh 1886. Reprinted 1966.

Christian, T., 1887. New diatomaceous deposits. The Microscope. 7 (3), 65.

Cleve, P. T., 1873. Examination of diatoms found on the surface of the Sea of Java. Bihang Svensk. Vetenskapsakad. Handl. 11 (2), $1,1$.

1873. On diatoms from the Arctic Sea. Bihang. till $\mathrm{Kgl}$. Svensk. Vetenskapsakad. Handl. 13, 1, 1 . 1894. Synopsis of the naviculoid Diatoms. Kgl. Svensk. Vetenskapsakad. Handl. 26, 1.

1896. Diatoms from Baffin Bay and Davis Strait. Bihang till Kgl. Svensk. Vetenskapsakad. Handl., Abt, III, 4, 22, 22 p.
1903. Plankton-researches in 1901 and 1902. $\mathrm{Kgl}$. Svensk. Vetenskapsakad. Handl. 8, 36.

Cleve, P. T. and Grunow, A., 1880. Beiträge zu Kenntnis der arktischen Diatomeen. Svensk. Ventenskapsakad. Handl., 2, 17, 3.

Cleve-Euler, A., 1951-1955. Die Diatomeen von Schweden und Finnland. Kgl. Svensk. Vetenskapsakad. Handl. (Bibliotheca Phycologica). 5 Vols. (Reprint)

Cox, A., 1969. Geomagnetic reversals. Science. 163, 237.

Cupp, E. E., 1943. Marine plankton diatoms of the west coast of North America. Bull. Scripps Inst. Oceanog., Univ. Calif. 5 (1), 1.

Dodimead, A. J., Favorite, F. and Hirano T., 1963. Salmon of the North Pacific, Part II, Review of Oceanography of the Subarctic Pacific Region. Bull. Intern. Pacific Fisheries Comm. 13,1.

Donahue, J. G., 1970. Diatoms as quaternary biostratigraphic and paleoclimatic indicators in high latitudes of the Pacific Ocean. PhD thesis, Faculty of Pure Science. Columbia Univ. 230 p.

1970. Pleistocene diatoms as climatic indicators in North Pacific sediments. Geol. Soc. Am. Mem. 126, 121.

Dymond, J. R., 1966. Potassium-argon geochronology of deep sea sediments. Science. 152, 1239.

Ehrenberg, C. G., 1830. Beiträge zur Kenntniss der Organisation der Infusorien und ihrer geographischen Verbreitung besonders in Sibirien. Abh. Kgl. Akad. Wiss. Berlin. (Preuss. Phys.). 1.

1837. Die fossilen Infusorien und die lebendige Dammerde. Abh. Kgl. Akad. Wiss. Berlin.

1838. Über die Bildung der Kreidefelsen und des Kreidemergels durch unsichtbare Organismen. Abh. Kgl. Akad. Wiss. Berlin. 59.

1838. Die Infusionthierchen als vollkommene Organismen. Ein Blick in das tiefere organische Leben der Natur. Leipzig. (Leopold Voss). I-XVII, 1.

1839. Uber noch jetzt zahlreich lebende Thierarten der Kreidebildung und den Organismus der Polythalamien. Abh. Kgl. Akad. Wiss. Berlin. 81.

Ehrenberg, C. G., 1840 (1841). Charakteristik von 274 neuen Arten von Infusorien. Ber. über die zur Bekanntmachung geeigneten Verhandlg. der königl. preuss. Akad. der Wissenschft. zu Berlin, (Berlin) 197.

1841. Uber Verbreitung und Einflu $\beta$ des mikroskopischen Lebens in Süd- und Nord Amerika. Ber. Bekanntmachung geeigneten Verh. Kgl. Preuss. Akad. Wiss. Berlin. 139.

1841. Verbreitung und Einflu $\beta$ des mikroskopischen Lebens in Süd- und Nord-Amerika. Abh. Kgl. Akad. Wiss. Berlin. (Phys. Abh.). (1), 291.

1844. Uber 2 neue Lager von Gebirgsmassen aus Infusorien als Meeres-Absatz in Nord-Amerika und eine Vergleichung derselben mit den organischen KreideGebilden in Europa und Afrika. Ber. Akad. Wiss. Berlin. 57.

1844. Einige vorläufige Resultate der Untersuchungen der von der Südpolreise des Capitain Ross, so wie in den Herrn Schayer und Darwin zugekommenen Materialien über das Verhalten des kleinsten Lebens in den Oceanen und den grö $\beta$ ten bisher zugänglichen Tiefen des Weltmeers. Ber. Bekanntmachung geeigneten Verg. Kgl. Preuss. Akad. Wiss. Berlin. 182.

1845. Neue Untersuchungen über das kleinste Leben als geologisches Moment. Ber. Bekanntmachung geeigneten Verh. Kgl. Preuss. Akad. Wiss. Berlin. 53. 1854. Mikrogeologie das Erden und Felsen 
schaffende Wirken des unsichtbar kleinen selbstständigen Lebens auf der Erde. Leipzig (Leopold Voss).

Fling, R. F., 1965. The Pliocene-Pleistocene boundary. Geol. Soc. Am. Spec. Paper 84, 497.

Forti, D. A., 1909. Studi per una Monografia del genere Pyxilla (diatomee) e dei generi affini. Nuova Notarisia. 20,5 .

Frenguelli, J., 1949. Diatomeas fósiles de los yacimientos chilenos de Tiltil y Mejillones. Darwinia. 2(1), 97.

Frenguelli, J. and Orlando, H. A., 1958. Diatomeas y silicoflagelados des sector Antartico Sudamericano. Inst. Antartico Argentino, Publ. 5, 13. Buenos Aires.

Gran, H. H., 1900. Bemerkungen über einige Planktondiatomeen. Nyt. Mag. f. Naturvidensk. Aberne. 38(2), 103.

1904. Die Diatomeen der Arktischen Meere. I Die Diatomeen des Planktons in "Fauna Arctica", auf Grund der Erg. der deutschen Expedition in das Nördliche Eismeer im Jahre 1898. 4, 511, Jena.

Gran, H. H. and Angst, E. C., 1931. Plankton diatoms of Puget Sound. Publ. Puget Sound Biol. Sta. Unit. Washington. 7, 417.

Gray, S. F., 1821. A natural arrangement of British plants according to their relations to each other as pointed out by Jussieu, De Candolle, Brown. Diatomaceae. London (Baldwin, Cradock and Joy). 1 (2 vol.) 824 p., 751 p.

Gregory, W., 1857. On new forms of marine Diatomaceae found in the Firth of Clyde and in Loch Fyne. Trans. Roy. Soc. Edinburg. 4, 21, 473.

Greville, R. K., 1860. A monograph of the genus A sterolam pra, including Asteromphalus and Spatangium . Trans. Microsc. Soc. London. 8, (n.s.), 102.

1862. Description of new and rare diatoms. Trans. Microsc. Soc. London. 10 (n.s.), 89.

1863. Descriptions of new and rare diatoms. Ser.

X. Quart. J. Microsc. Sci., III (n.s.), 227 1865. Description of new and rare diatoms. Ser. XIV. Trans. Microsc. Soc. London. 13 (n.s.), 1.

1866. Descriptions of new and rare diatoms. Trans. Microsc. Soc. London. 14 (n.s.), (Ser. XVII), 1; (Ser. XIX), 77; (Ser. XX), 121.

Grunow, A., 1868. Algae in "Reise der österreichschen Fregatte Novara um die Erde in den Jahren 1857, 1858, 1859". Bot. 1, 1.

1870. Algae in Reise der österreichschen Fregatte Novara um die Erde in den Jahren 1857-1859. Bot. 1, 1. 1878. In Schneider, Naturw. Beitr. 2, Kenntn. der Kaukasusländer.

, 1880. In Cleve, P. T. and Grunow, A, Beiträge zur Kenntnis der Arktischen Diatomeen. Kong. Svensk. Vet.-Akad. Handl., (Stockholm) 17 (2), 3. 1880. In H. van Heurck, Synopsis des Diatomèes de Belgique, Atlas. (Ducaju \& Cie), Anvers plts 1-30. , 1881. In H. van Heurck, Synopsis des diatomées de Belgique. Atlas. Taf. 124, Fig. 10. 1883. In H. van Heurck, Synopsis des Diatomèes de Belgique, Atlas, (Ducaju \& Cie), Anvers Plts. 104-132. 1883. Botanisch. Centralblatt, $10,15,36$.

1884. Die Diatomeen von Franz Josefs-Land. Denkschr. Kgl. Akad. Wiss. Wien, Math. Nat. Wiss. Kl. 48.

Hanna, G. D., 1930. A review of the genus Rouxia. J. Paleont. 4(2), 179.

1930. Observations on Lithodesmium cornigerum Brun. J. Paleont. 2, 4, 189.

1932. The diatoms of Sharktooth Hill, Kern County, California. Proc. Calif. Acad. Sci. 4th Ser. 20(6), 161 .
Hanna, G. D. and Grant, W. M., 1926. Expedition to the Revillagigedo Islands, Mexico, in 1925, II Miocene marine diatoms from Maria Madre Island, Mexico. Calif. Acad. Sci. 4th Ser. 2, 15, 115.

Hasle, G. R., 1960. Phytoplankton and silicate species from the tropical Pacific. Skrift. det Norske Videnskapsakad. Oslo. Matemat. Naturv., 2, 1.

1965. Nitzschia and Fragilariopsis, species studied in the light and electron microscopes. III. The Genus Fragilariopsis. Skrift. det Norske Videnskapsakad. Oslo. (n.s.) 21, 5 .

Hasle, R. G. and Mendiola, B. R. E. de, 1967. The fine structure of some Thalassionema and Thalassiothrix species. Phycologia. 2+3, 6, 107.

Hays, J. D., 1970. The stratigraphy and evolutionary trends of Radiolaria in North Pacific deep-sea sediments. Geol. Soc. America, Mem. 126, 185.

Hassal, A. H., 1845. A history of the British Freshwater Algae (including descriptions of Diatomaceae and Desmidiaceae) with upwards of one hundred plates. Taylor, Walton and Maberly (London) 1 and 2, 462 p., $102 \mathrm{pl}$.

Hendey, N. I., 2964. An introductory account of the smaller algae of British Coastal Waters. Part V: Bacillariophyceae (Diatoms). Fishery Invest. London. Ser. 4,1 .

Hendey, N. I. and Wiseman, D. H., 1953. The significance and diatom content of a deep-sea floor sample from the neighbourhood of the greatest oceanic depth. Deep-Sea Res. 147

Hustedt, F., 1930. Bacillariophyta (Diatomeae). A. Pascher, Die Süßwasser-Flora Mitteleuropas, 10 1. 2. Auflg. (Fischer), Jena.

1958. Diatomeen aus der Antarktis und dem Südatlantik. Deutsche Antarkt. Exped. 1938/1939. Hamburg. 2, 104.

1959. Die Kieselalgen Deutschlands, Österreichs und der Schweiz unter Berücksichtigung der übrigen Länder Europas sowie der angrenzenden Meeresgebiete. Kryptogamen-Flora von Deutschl., Osterr. u. d. Schweiz, Teil 2, 7, 1 .

1962. Die Kieselalgen Deutschlands, Osterreichs und der Schweiz unter Berücksichtigung der übrigen Länder Europas sowie der angrenzenden Meeresgebiete. Krytogamen-Flora von Deutschl., Osterr. u. d. Schweiz, Teil, 1, 7, 1. Leipzig 1930, Neudruck Weinheim.

1964. Die Kieselalgen in Rabenhorst etc. Lieferung 3, 349 .

Janisch, A. S., 1878. In A. Schmidt. Atlas der Diatomaceenkunde. Taf. 57.

Joergensen, E., 1905. The Protist Plankton and the Diatoms in bottom samples. In O. Nordgaard, Hydrographical and Biological Investigations in Norwegian Fjords. Bergens Museum Skrift. 254 s. Bergen (John Grieg).

Jousé, A. P., 1959. Principal development stages of marine diatoms of the far east in the Tertiary and Quaternary periods. Botanicheskiy Zhurnal (Botanical Journal). 44(1), 44.

1961. Diatoms and their roles in indicating the history of oceans. Izd. Akad. Nauk S.S.S.R., Ser. Geog. 2,13 .

1962. Stratigraphische und paläogeographische Untersuchungen im Nordwestteil des Pazifik. Verlag Akad. Wiss. USSR, 5 Moskau.

1968. Species novae Bacillariophytorum in sedimentis fundi Oceani Pacifici et Maris Ochotensis 
inventae. Akad. Nauk. SSSR., Botanicheskii Institut, Novitates systematicae plantarum non vascularum. 3, 12 . Moskau.

- 1971. Species formaeque novae et curiosae bacillariophytorum in sedimentis fundi oceani pacifici. Novitates systematicae plantarum non vascularum, Akad. Nauk. SSSR. 8, 12. Leningrad.

1971. Diatoms in pleistocene sediments from the Northern Pacific Ocean. In Micropaleontology of the Oceans., Funnel, B. M. and Riedel, W. R. (Eds.). Cambridge (Cambridge University Press). 407.

Kanaya, R., 1957. Eocene diatom assemblages from the Kellogg and "Sidney" Shales, Mt. Diablo Area, California. Sci. Rept. Tohoku Unit. 2nd Ser. 28, 124 p. , 1959. Miocene diatom assemblages from the Onnagawa Formation and their distribution in the correlative formations in Northeast Japan. Sci. Rept. Tohoku Univ. 2nd Ser. (Geol.). 30, 1.

1969. Diatom micropaleontology and deep-sea stratigraphy of the North Pacific. La mer (Bull. Soc. Franco-Japonaise d'Océanogr.). 7(3), 183.

1971. Some aspects of pre-Quaternary diatoms in the ocean. In Micropaleontology of the Oceans. Funnel, B. M. and Riedel, W. R. (Eds.). Cambridge (Cambridge University Press). 545.

Kanaya, T. and Simonsen, R., 1961. Notes on the marine species of the diatom genus Denticula Kütz, Intern. Rev. Hydrobiol. 46(4), 498.

Kanaya, T. and Koizumi, I., 1966. Interpretation of diatom Thanatocoenoses from the North Pacific applied to a study of Core V20-130 (Studies of a deep-sea Core V20-130. Part IV). Sci. Rept. Tohoku Univ., 2nd Ser. (Geol.), 37(2), 89.

, 1970. The progress in the younger Cenozoic diatom biostragigraphy in the Northern Circum-Pacific region. J. Marine Geol. (Japan). 6(2), 47.

Kanaya, T., Kobayashi, K. Kitazawa, K. and Sakai, T., 1971. Magnetic and micropaleontological study of deep-sea sediments from the west-central equatorial Pacific. Deep-Sea Res. 18, 1045.

Karsten, G., 1928. Abteilung Bacillariophyta (Diatomeae). In A. Engler and K. Prantl, Die natürlichen Pflanzenfamilien. Auflage 2, 2, 105 . Leipzig. (Wilhelm Engelmann).

Kitton, F., 1971. Diatomaceous deposits from Jutland. J. Quekett Micros. Club. London. 2, 99.

Koizumi, I., 1968. Tertiary diatom flora of Oga Peninsula, Akita Prefecture, Northeast Japan. Sci. Rept. Tohoku Univ. 2nd Ser. (Geol.), 40(3), 171.

Kolbe, R. W., 1954. Diatoms from equatorial Pacific cores. Rept. Swedish Deep-Sea Exped. 6(1), 3.

Kützing, F. T., 1833. Synopsis Diatomacearum oder Versuch einer systematischen Zusammenstellung der Diatomeen. Linnaea. Berlin. 8, 529.

1844. Die kieselschaligen Bacillarien oder Diatomeen. 152 S. Nordhausen.

Lohman, K. E., 1938. Pliocene diatoms from the Kettleman Hills, California. In Shorter Contributions to General Geology. U. S. Geol. Surv. Prof. Paper 189-C, 81.

1948, Middle Miocene diatoms from the Hammond Well. In Cretaceous and Tertiary Subsurface Geology. Maryland Dept. Geol., Mines and Water Res. Bull. 2151.

Mandra, Y. T., 1960. Fossil Silicoflagellates from California, USA. Rep. Int. Geol. Congr., XXI Sess., Part VI, Pre-Quarternary Micropaleontology. Copenhagen. 77 .
Martini, E., 1971. Standard Tertiary and Quaternary calcareous nannoplankton zonation. Proc. II Planktonic Conf. Roma, 1970. A. Farinacci (Ed.). 739.

1971. Neogene silicoflagellates from the equatorial Pacific. In Winterer, E. L., Riedel, W. R. et al., 1971. Initial Reports of the Deep Sea Drilling Project, Volume VII. Washington (U.S. Government Printing Office). 1965 .

— 1972. Der stratigraphische Wert von Silicoflagellaten im Jungtertiär von Kalifornien und des östlichen Pazifischen Ozeans. Nachr. Deutsch. Geol. Gesell. 5, 47.

Martini, E. and Bramlette, M. S., 1963. Calcareous nannoplankton from the experimental Mohole drilling. J. Paleontol. 37, 845 .

Martini, E. and Worsley, T., 1970. Standard Neogene calcareous nannoplankton zonation. Nature. 225(5229), 289.

Mertz, D., 1966. Mikropaläontologische und sedimentologische Untersuchung der Pisco-Formation Südperus. Palaeontographica Abt. B, 118, 1. Stuttgart.

Milow, D. E., 1971. In McManus, D. A. and Burns, R. E. (eds.). Initial Report of the Deep Sea Drilling Project, Volume V. Washington 1970.

Moore, T., Radiolaria. In Tracey, I. I. and Sutton, G. H. (Eds). Initial Report Deep Sea Drilling Project, VIII, 727-775, Washington 1971.

Muchina, V. V., 1965. De speciebus diatomearum novis e depositibus partis aequatorialis oceani pacifici. (In Russian). Acad. Sci. USSR, Inst. Bot. Nomine V. L. Kamarovii, 22. Moskau-Leningrad.

Pantocsek, J., 1886. Beiträge zur Kenntnis der fossilen Bacillarien Ungarns. Marine Bacillarien. Pt. 1.

, 1903. Beiträge zur Kenntnis der fossilen Bacillarien Ungarns. 2. verbesserte Aufl. 3 Teile, W. Junk, Berlin.

Parker, F. L., 1964. Foraminifera from the Experimental Mohole Drilling near Guadalupe Island, Mexico. J. Paleontol. 38 (4), 617.

Peragallo, H., 1892. Monographie du genre Rhizosolenia et dur quelques genres voisins. Le Diatomiste. 1, 79 and 99.

Proskina-Lavrenko, A. I., See Hasle, 1960.

Ralfs, J., 1861. In Pritchard, A History of Infusoria, Living and Fossil. Ed. IV, revised and enlarged. London. 968 p.

Rattray, J., 1889. A revision of the Genus Coscinodiscus Ehr., and some allied genera. Proc. Roy. Soc. Edinburgh. 16, 449. Reprint, Neill and Company, Edinburgh.

1890. A revision of the genus Actinocyclus Ehrb. J. Quekett Micros. Club. 2nd Ser. 4, 137.

Reinhold, T., 1937. Fossil diatoms of the neogene of Java and their zonal distribution. Verhandel. Geol.-Mijn-bou. Genootschap, Geol. Ser. 12, 43.

Riedel, W. R. and Sanfilippo, A., 1971. Cenozoic radiolaria from the western tropical Pacific, Leg 7. In Winterer, E. L., Riedel, W. R et al., 1971. Initial Reports of the Deep Sea Drilling Project, Volume VII. Washington (U.S. Government Printing Office). 1529.

Roper, F. C., 1858. Notes on some species and varieties of British marine Diatomaceae. Quart. J. Microsc. Sci. 6, 17.

1859. On the genus Biddulphia and its affinities. Trans. Microsc. Soc. London. 7, 1.

Saito, T., 1963. Miocene planktonic Foraminifera from Honshu, Japan. Tohoku Univ. Sci. Rep., 2nd Ser. (Geol.). 35 (2), 124.

Sabelinia, M. M., 1934. Die Diatomeen der tertiären Ablagerungen des Ostufers von Kamtschatka. Trudy neft. geol. rasv. inst., Ser. A, 48, 3 . 
Sawamura, K., 1963b. Fossil diatoms in the Oidawara Formation of the Mizunami Group. Bull. Geol. Surv. Japan. 14 (5), 387.

Scheshukova-Poretskaja, V. S., 1962. Novie i redkie Bacillariophyta iz diatomovoi sviti Sakhalina. Uchenie Zapiski lgu, Ser. Biol. Nauk (Leningrad Univ.) 49(313), 203.

1964. New and rare marine diatoms of the Neogene of Sakhalin and Kamchatka (in Russian). Nov. System. Plant. non Vascularium, Bot. Inst., Akad. Nauk. SSSR. 69.

, 1967. Neogenowye morskie diatomowye wodorosli sachalina i kamuatki. Verlag Leningrader Univ. (Leningrad). 5.

Schmidt, A., 1874. Atlas der Diatomaceenkunde. Taf. 163, Leipzig.

, 1878. Atlas, Atlas, Taf. 59.

Schrader, H.-J., 1969. Die Pennaten Diatomeen aus dem Obereozän von Oamaru, Neuseeland. Beih. Nova Hedwigia 28, 1. Lehre.

, 1972. Kieselsäure-Skelette in Sedimenten des ibero-marokkanischen Kontinentalrandes und angrenzender Tiefsee-Ebenen. "Meteor'-Forsch.-Ergebnisse, Reihe C, 8, 10. Berlin-Stuttgart.

, in press. Revised diatom stratigraphy of the
Experimental Mohole Drilling, Guadalupe Site. Occ. Pap. Calif. Acad. Sc., San Francisco.

, in press. Stratigraphic distribution of marine Denticula species in Neogene North Pacific sediments. Micropaleontol. New York.

Smith, H. L., 1887. In Christian, Raphidodiscus. The Microscope. 7, 67:

Smith, W., 1851. Notes on the Diatomaceae, with description of British species, included in the genera Campylodiscus, Surirella, Cymatopleura. Ann. Mag. Nat. Hist. 2, 7, 1 . 1856. Synopsis of British distomaceae. John van Voorst, 2, 107 p. London.

Tempère, J. and Peragallo, H., 1910. Diatomees du Monde Entier, Ed. 2, 30 fasc. Arcachon, Grez-sur-Loing (S.-et-M.), Pt 1, 209.

Turpin, P. J. F., 1828. Observations sur le nouveau genre Surirella. Mem. Mus. Hist. Naturelle, Paris. 16, 361.

Wallich, G. C., 1860. On the siliceous organisms found in the digestive cavities of the Salpae, and their relation to the Flint nodules of the Chalk Formation. Trans. Micros. Soc. London, 8, (n.s.), 36.

Wornardt, W. W., Jr., 1967. Miocene and pliocene marine diatoms from California. Calif. Acad. Sci. Occasional Paper. 63, 1 . 


\begin{tabular}{|c|c|c|c|}
\hline \multicolumn{4}{|c|}{ Ranges of selected diatom species at S1te 173} \\
\hline Diatom species & $\begin{array}{l}\text { last } \\
\text { occurrence }\end{array}$ & first & meters \\
\hline $\begin{array}{l}\text { Denticula seminae } \\
\text { Actinocyclus ochotensis } \\
\text { Nitzschia marina } \\
\text { Stephanopyxis dimorpha } \\
\text { Thalassiosira gravida } \\
\text { Thalassiosira oestrupii } \\
\text { Raphoneis cocconeides } \\
\text { Rhizosolenia curvirostris } \\
\text { Stephanopyxis californica } \\
\text { Nitzschia reinholdii } \\
\text { Actinocyclus oculatus } \\
\text { Thalassiosira nidulus } \\
\text { Nitzschia fossilis } \\
\text { Rhizosolenia barboi } \\
\text { Thalassiosira antiqua } \\
\text { Raphoneis angustata } \\
\text { Nitzschia californica } \\
\text { Denticula kamtschatica } \\
\text { Thalassiosira convexa } \\
\text { Nitzschia jouseae } \\
\text { Rhizosolenia praealata } \\
\text { Actinocyclus ellipticus } \\
\text { Denticula hyalina } \\
\text { Pseudopyxilla americana } \\
\text { Actinocyclus ingens } \\
\text { Hemiaulus polymorphus } \\
\text { Lithodesmium minusculum } \\
\text { Nitzschia miocenica } \\
\text { Nitzschia praereinholdii } \\
\text { Raphoneis sacchalinensis } \\
\text { Thalassiosira usatchevii } \\
\text { Brunia mirabilis } \\
\text { Nitzschia rolandii } \\
\text { Nitzschia praefossilis } \\
\text { Thalassiosira praeconvexa } \\
\text { Coscinodiscus cof.lacustris } \\
\text { Coscinodiscus temperi } \\
\text { Cladogramma dubium } \\
\text { Coscinodiscus endoi } \\
\text { Rhizosolenia miocenica } \\
\text { Denticula dimorpha } \\
\text { Denticula lauta } \\
\text { Denticula punctata } \\
\text { Hemidiscus simplicissimus } \\
\text { Coscinodiscus praepaleaceus } \\
\text { Coscinodiscus plicatus } \\
\text { Denticula punctata f. hustedti } \\
\text { Rhizosolenia praebarboi } \\
\text { Coscinodiscus yabei } \\
\text { Coscinodiscus paleaceus } \\
\text { Nouxia naviculoides } \\
\text { Cotzschia challengeri } \\
\text { Rouxiadiploneides } \\
\text { Raphoneis miocenica } \\
\text { Thodas }\end{array}$ & $\begin{array}{l}1-1-110 / 111 \\
1-1-110 / 111 \\
7-1-67 / 68 \\
1-1-110 / 111 \\
1-1-110 / 111 \\
1-1-110-111 \\
1-1-110 / 111 \\
1-3-43 / 44 \\
2-3-38 / 39 \\
3-1-43 / 44 \\
4-2-55 / 56 \\
4-3-55 / 56 \\
6-3-55 / 56 \\
7-1-67 / 68 \\
8-3-55 / 56 \\
8-3-55 / 56 \\
9-1-55 / 56 \\
9-3-55 / 56 \\
10-6-55 / 56 \\
12-1-55 / 56 \\
12-3-55 / 56 \\
14-2-95 / 96 \\
14-3-55 / 56 \\
14-3-55 / 56 \\
14-3-55 / 56 \\
15-4-55 / 56 \\
15-4-55 / 56 \\
16-1-69 / 70 \\
16-1-69 / 70 \\
16-1-69 / 70 \\
16-1-69 / 70 \\
16-1-69 / 70 \\
16-3-55 / 56 \\
17-3-55 / 56 \\
18-2-55 / 56 \\
18-2-55 / 56 \\
18-5-55 / 56 \\
18-0 C \\
19-2-55 / 56 \\
19-2-55 / 56 \\
19-2-55 / 56 \\
19-4-55 / 56 \\
19-4-55 / 56 \\
19-4-55 / 56 \\
19-4-55 / 56 \\
20-2-55 / 56 \\
21-1-55 / 56 \\
121-1-55 / 56 \\
21-1-99 / 100 \\
21-3-55 / 56 \\
21-3-55 / 56 \\
23-2-55 / 56 \\
25-1-95 / 96 \\
26-1-120 / 121 \\
26-3-55 / 56 \\
28-2-44 / 45 \\
1045\end{array}$ & $\begin{array}{l}15-2-55 / 56 \\
3-1-43 / 44 \\
17-3-55 / 56 \\
15-C C \\
14-2-95 / 96 \\
9-5-55 / 56 \\
14-C C \\
10-\mathrm{BP} \\
8-4-55 / 56 \\
13-3-55 / 56 \\
15-\mathrm{CC} \\
11-\mathrm{EP} \\
12-2-55 / 56 \\
17-3-55 / 56 \\
21-1-99 / 100 \\
17-2-55 / 56 \\
20-\mathrm{CC} \\
20-3-55 / 56 \\
16-2-55 / 56 \\
17-3-55 / 56 \\
17-2-55 / 56 \\
19-\mathrm{CC} \\
25-3-55 / 56 \\
16-2-55 / 56 \\
16-1-69 / 70 \\
31-1-132 / 134 \\
30-\mathrm{CC} \\
20-2-55 / 56 \\
19-\mathrm{CC} \\
20-2-55 / 56 \\
19-2-55 / 56 \\
17-2-55 / 56 \\
29-2-57 / 59 \\
25-4-55 / 56 \\
19-2-55 / 56 \\
20-\mathrm{CC} \\
18-\mathrm{CC} \\
22-1-101 / 102 \\
26-\mathrm{CC} \\
29-2-57 / 59 \\
28-\mathrm{CC} \\
22-\mathrm{CC} \\
29-\mathrm{CC} \\
29-1-55 / 56 \\
22-2-55 / 56 \\
25-\mathrm{CC} \\
24-\mathrm{CC} \\
22-\mathrm{CC} \\
27-\mathrm{CC} \\
27-1-107 / 108 \\
25-3-55 / 56 \\
26-2-52 / 53 \\
26-\mathrm{CC} \\
30-\mathrm{CC} \\
27-3-55 / 56 \\
31-1-132 / 134\end{array}$ & 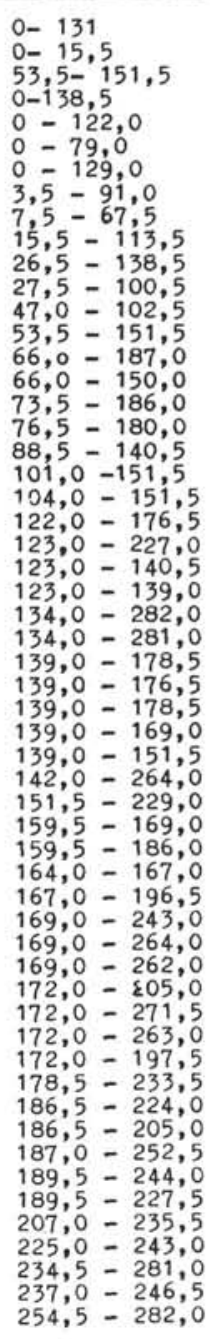 \\
\hline
\end{tabular}

Figure 1. Ranges of selected diatom species at Site 177. 


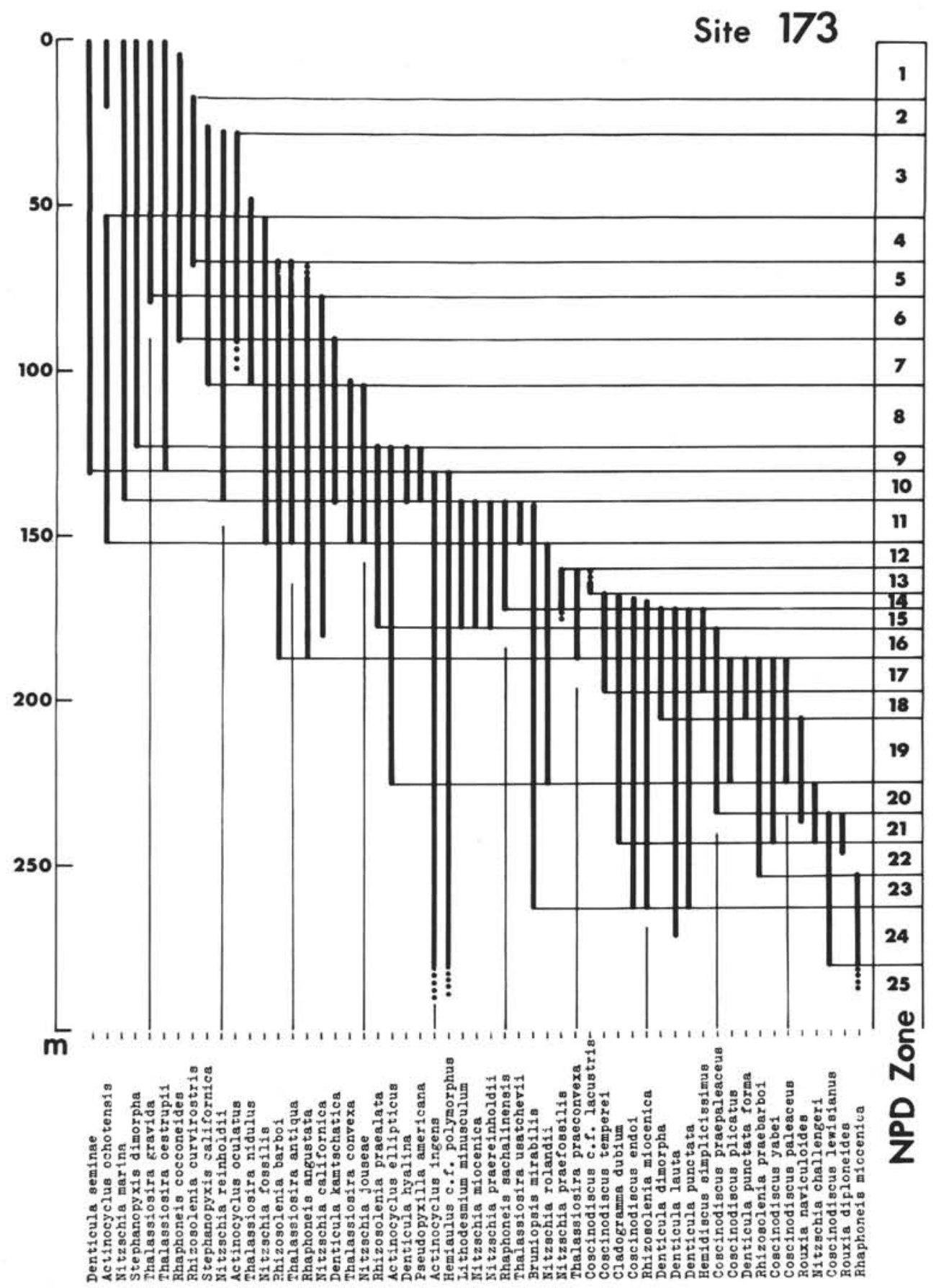

Figure 2. Ranges of selected diatom species at Site 173. 

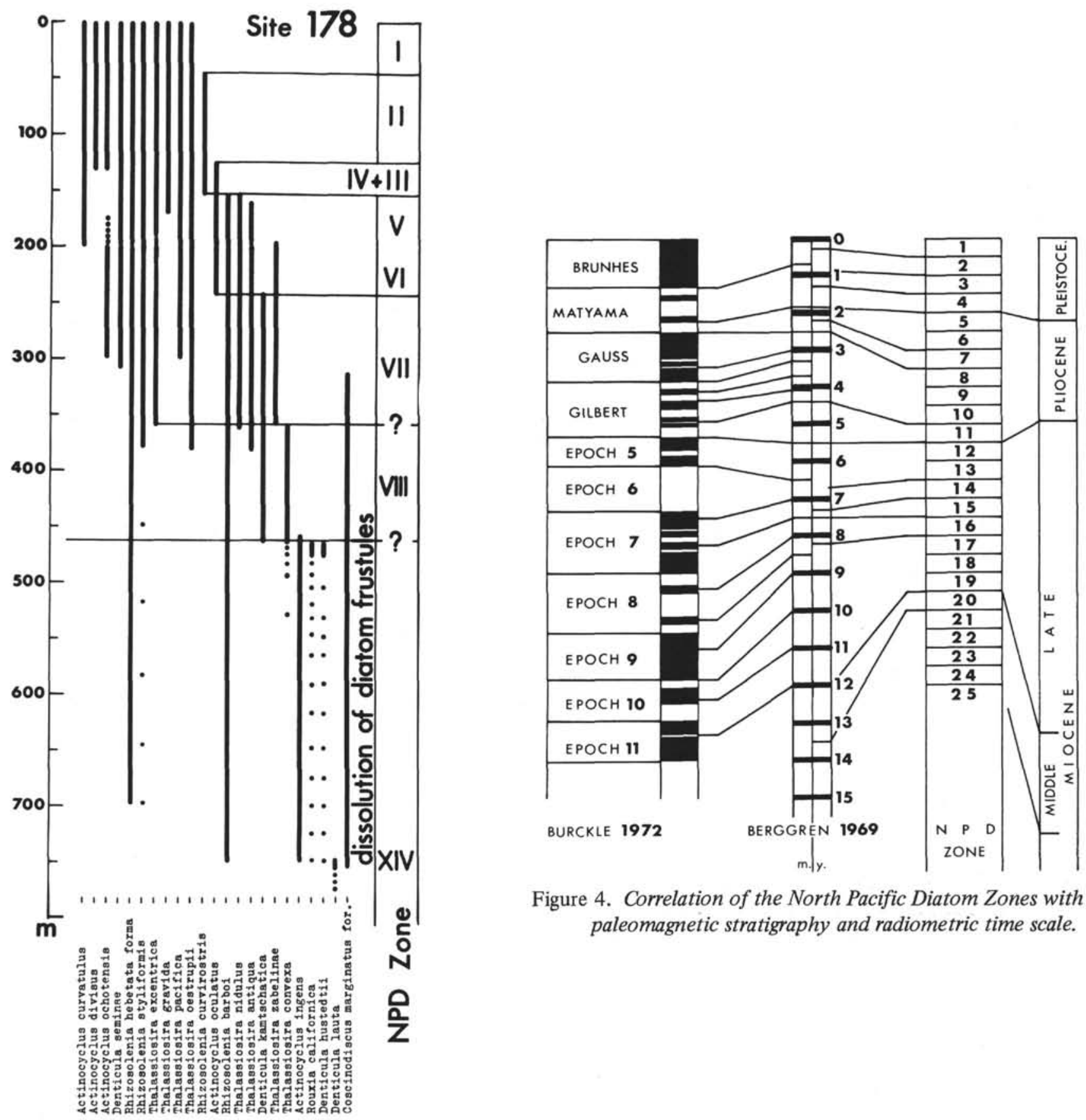

Figure 4. Correlation of the North Pacific Diatom Zones with paleomagnetic stratigraphy and radiometric time scale.

Figure 3. Ranges of selected diatom species at Site 178. 


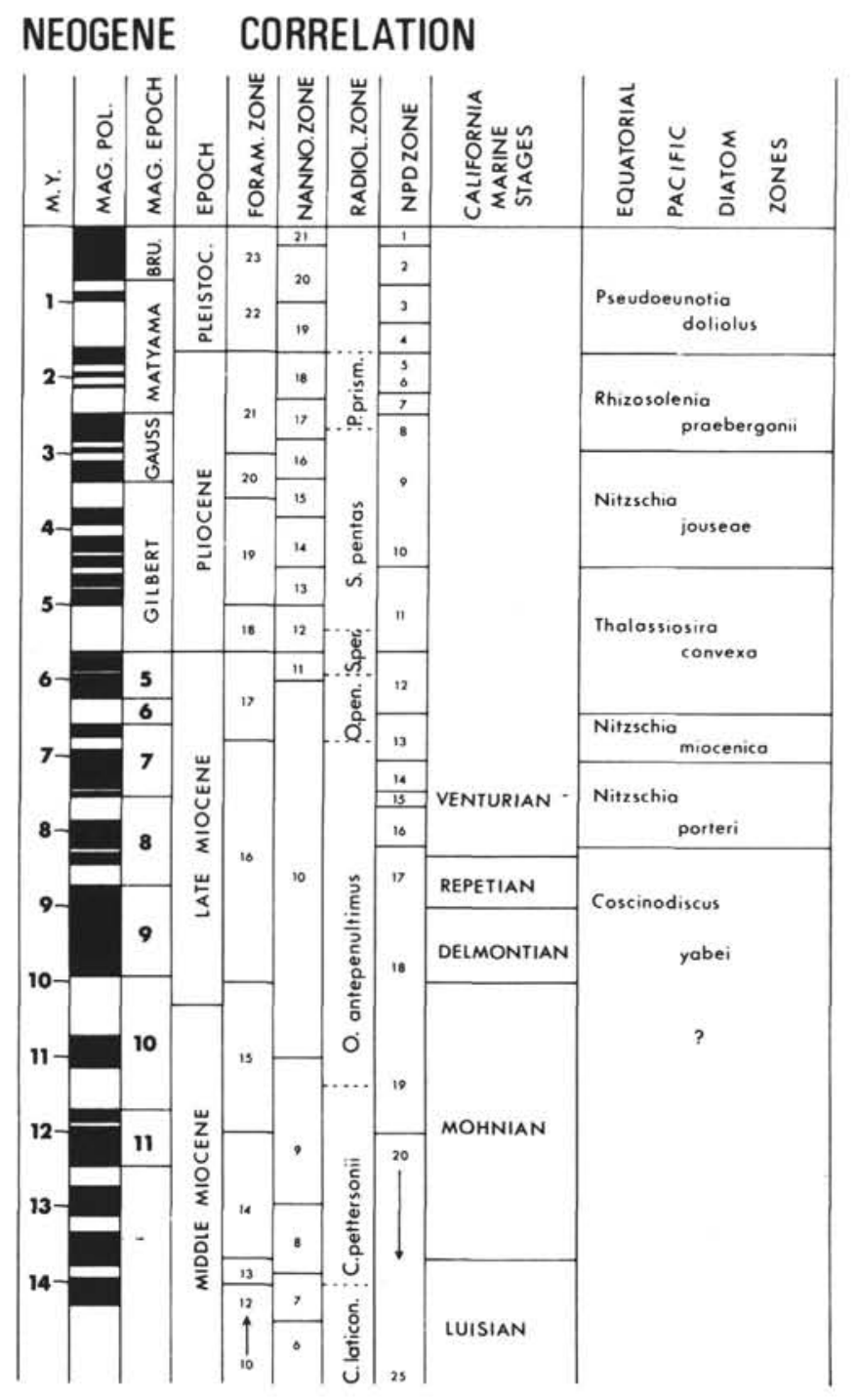

Figure 5. Estimated time relationship and correlation of Neogene planktonic microfossil zones (after Berggren, 1972; planktonic foraminiferal zones (Blow, 1969); calcareous nannoplankton zones (Martini, 1971; Bramlette \& Wilcoxon, 1967; Baumann \& Roth, 1969; Martini and Worsley, 1970); radiolarian zones (Riedel and Sanfilippo, 1971, Moore, 1971); North Pacific Diatom Zones (Schrader, MS., 1972); Equatorial Pacific Diatom Zones (Burckle, 1972); paleomagnetic stratigraphy (Abdel-Monnem, et al. 1971 ); radiometric time scale in part from Cox, 1969 and Abdel-Monem et al. 1971.

Figure 6. Correlation of North Pacific Diatom Zones 20-25 with silicoflagellate Zones (Martini 1972) and with Standard Nannoplankton Zones (Martini, 1971), with Californian Marine Stages as shown by foraminifera (Parker 1964) and Diatoms (Kanaya, 1971).

\section{EMD MULTIPLE CORRELATION}

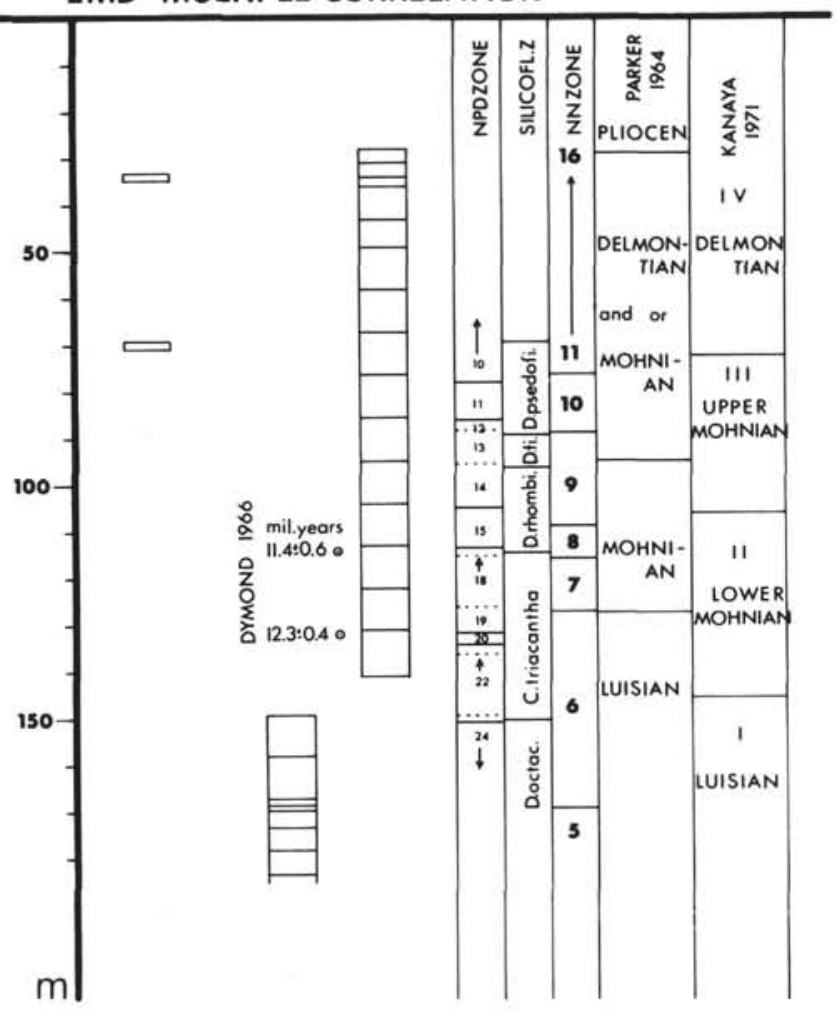




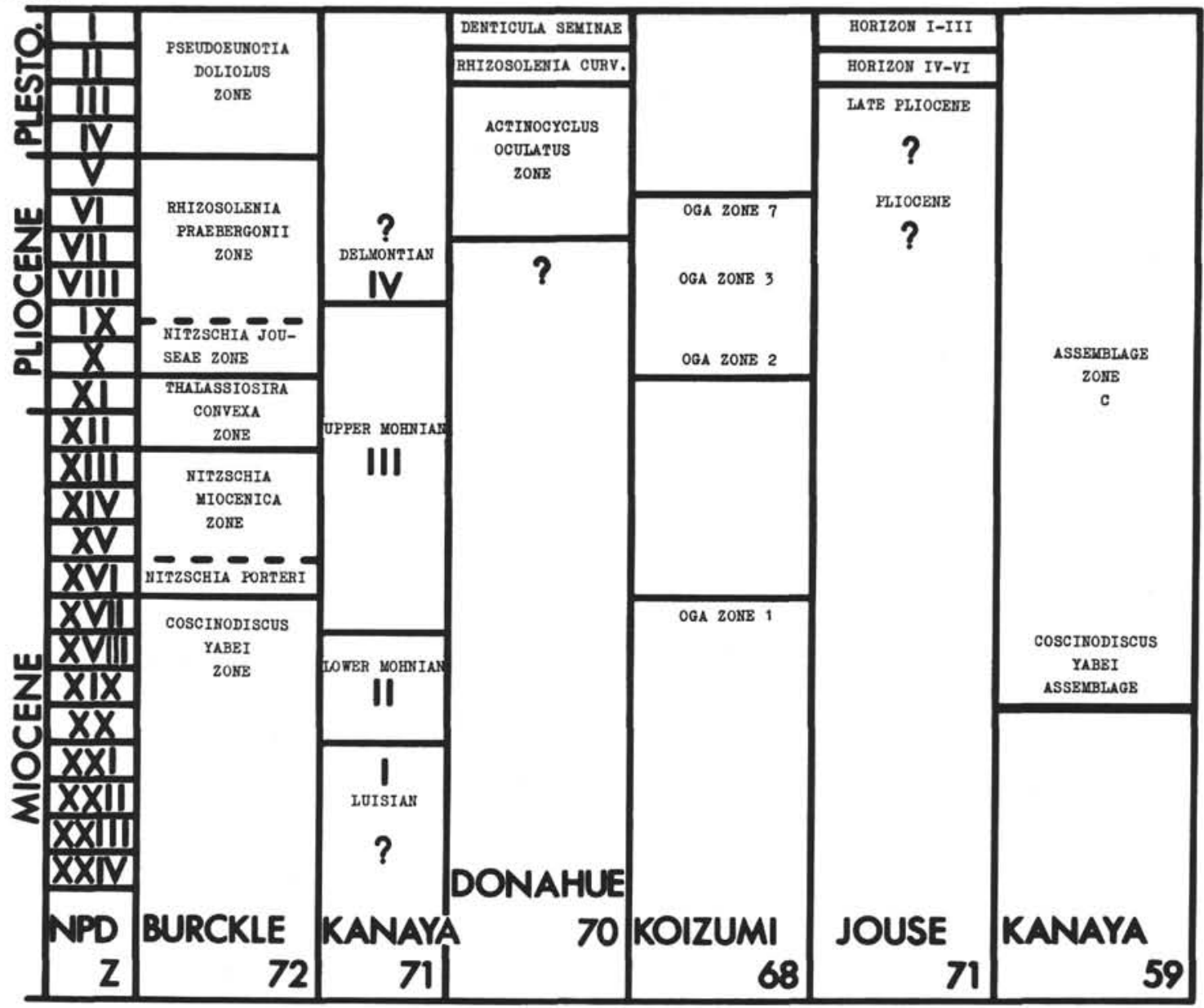

Figure 7. Correlation of the North Pacific Diatom Zones 1-25 with the Equatorial Pacific Zonation of Burckle, with the Experimental Mohole Zonation of Kanaya (1971), with the North Pacific Diatom Zonation of Donahue (1970), with the Oga Diatom Zonation of Koizumi (1968), with the Diatom Zonation of the North Pacific of Jouse (1971), and with the Onnagawa Formation of Kanaya (1959).

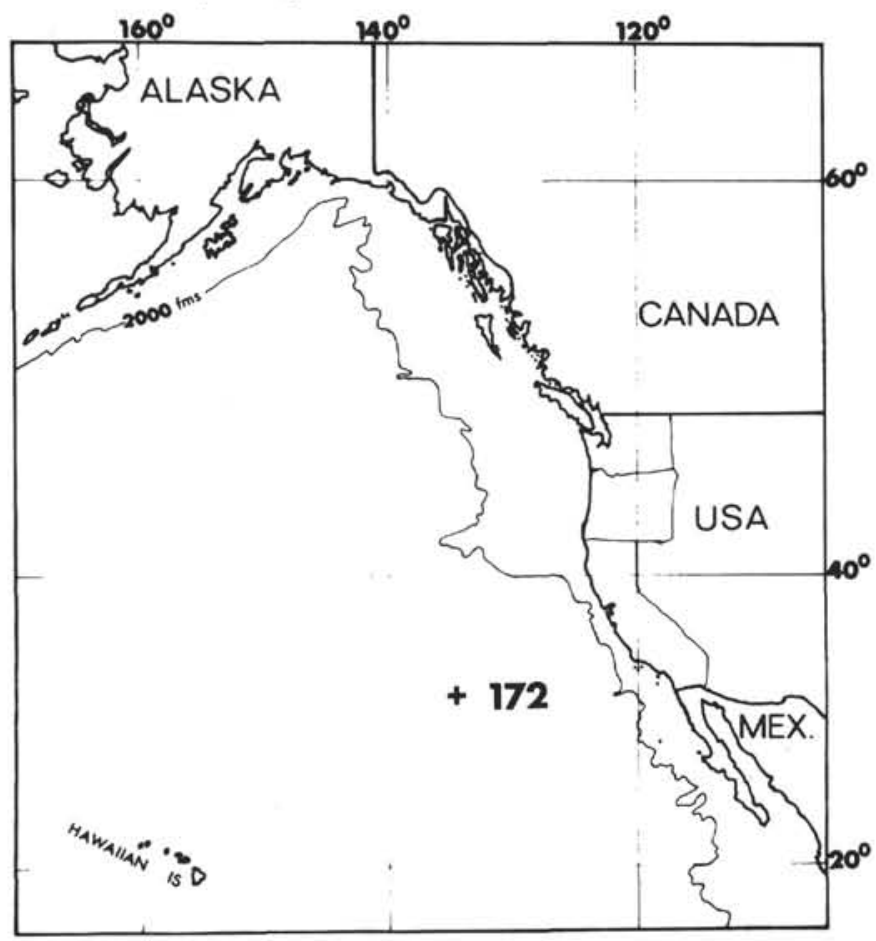

Figure 8. Location of Site 172.

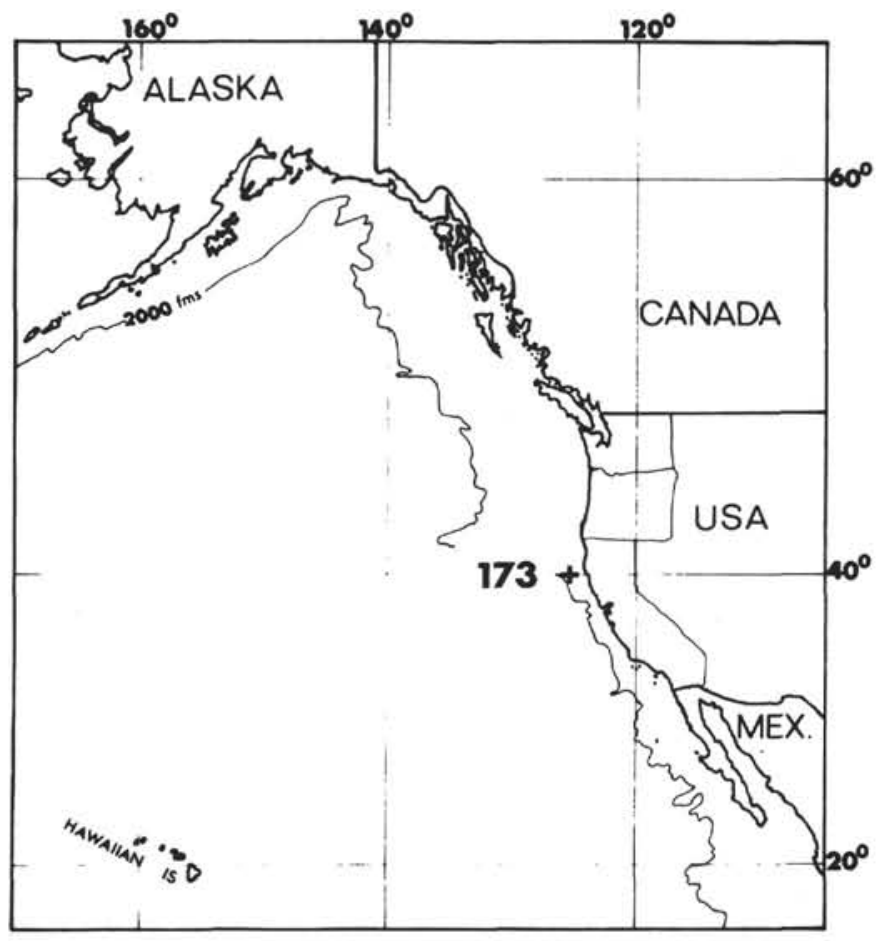

Figure 9. Location of Site 173. 


\section{Site 173}

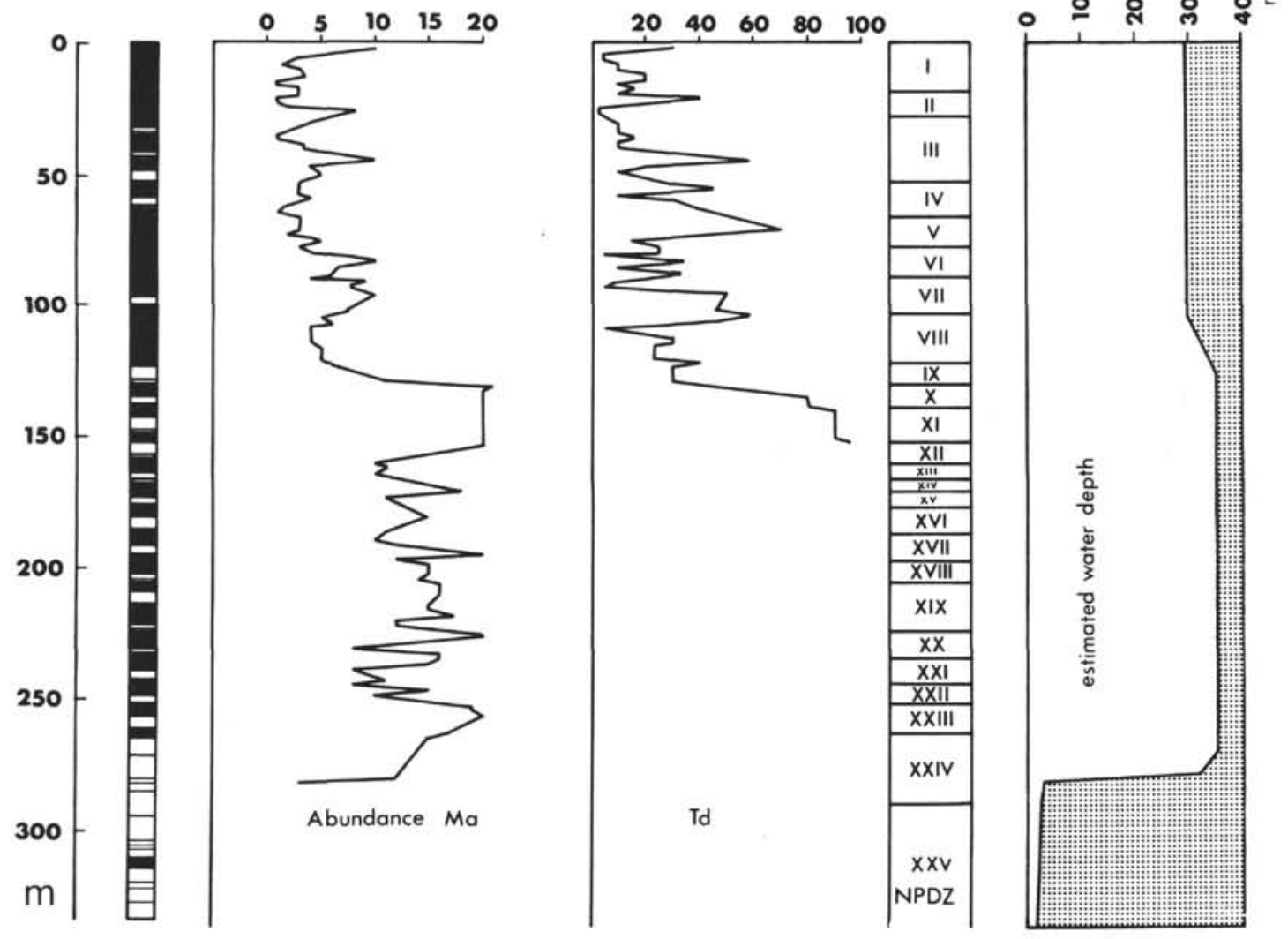

Figure 10. Site 173. Total Diatom abundance, Td, Biostratigraphic zonation, and water depth versus core depth. Recovered intervals black. Abundance determined by Method A. Average Td values below the Jaramillo Event (base of NPD Zone II) are slightly higher than those above.

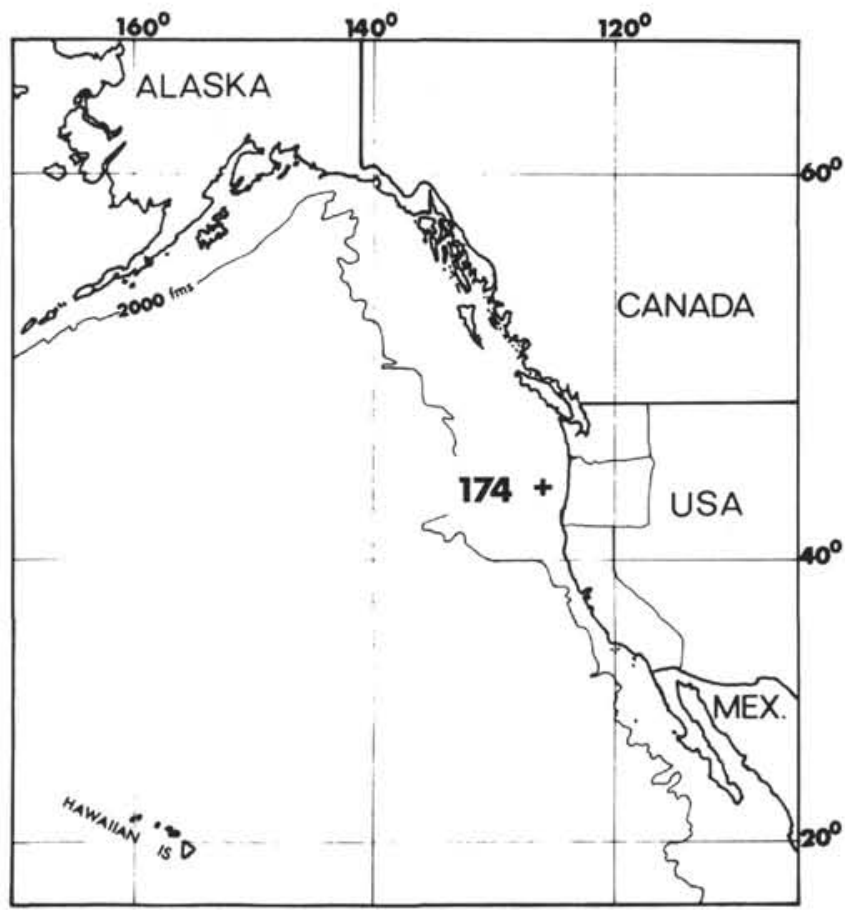

Figure 11. Location of Site 174. 


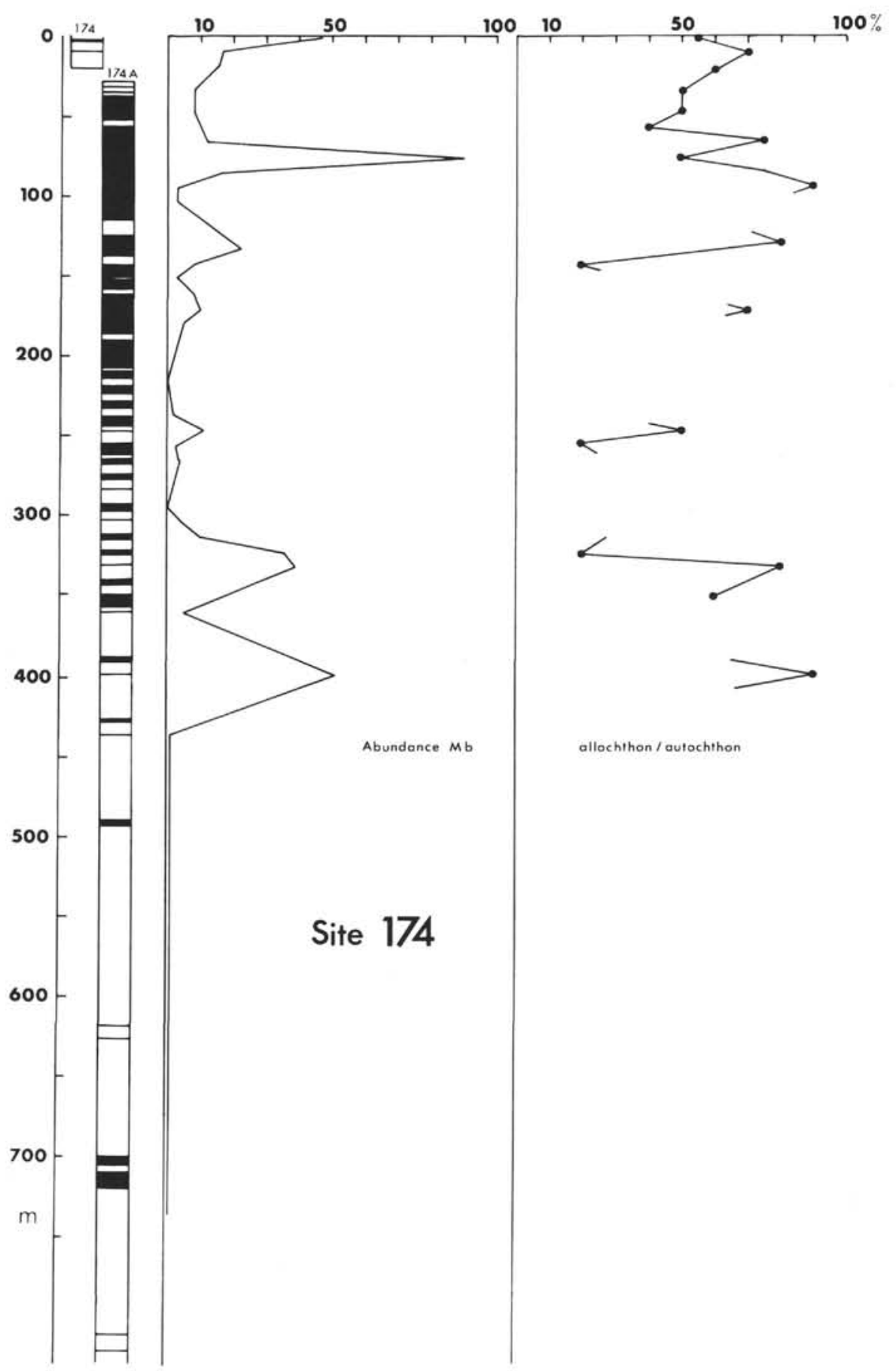

Figure 12. Site 174. Total diatom abundance and displaced floras, versus core depth. Recovered intervals black. Abundance by Method B. Displaced floras represented by ratio (\%) of allochtonous (marine benthonic plus freshwater planktonic and benthonic) to autochthonous (marine-planktonic) diatoms. Two hundred individuals of the fraction coarser than $44 \mu$ were counted from each core catcher sample. 


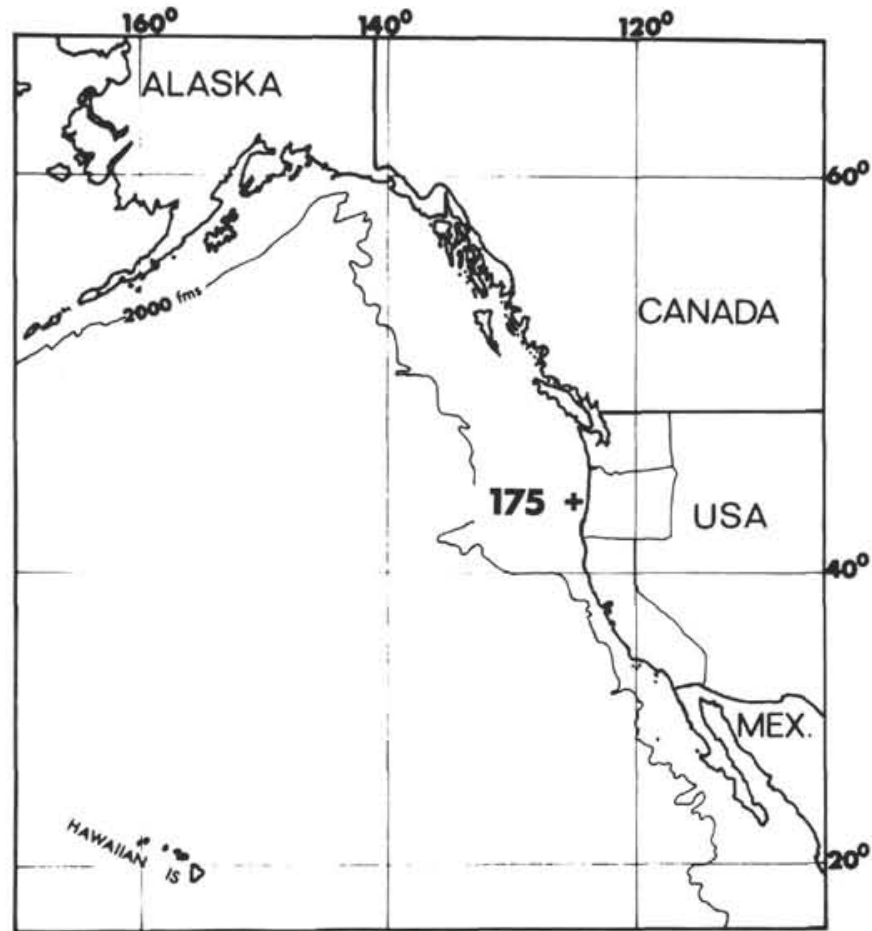

Figure 13. Location of Site 175.

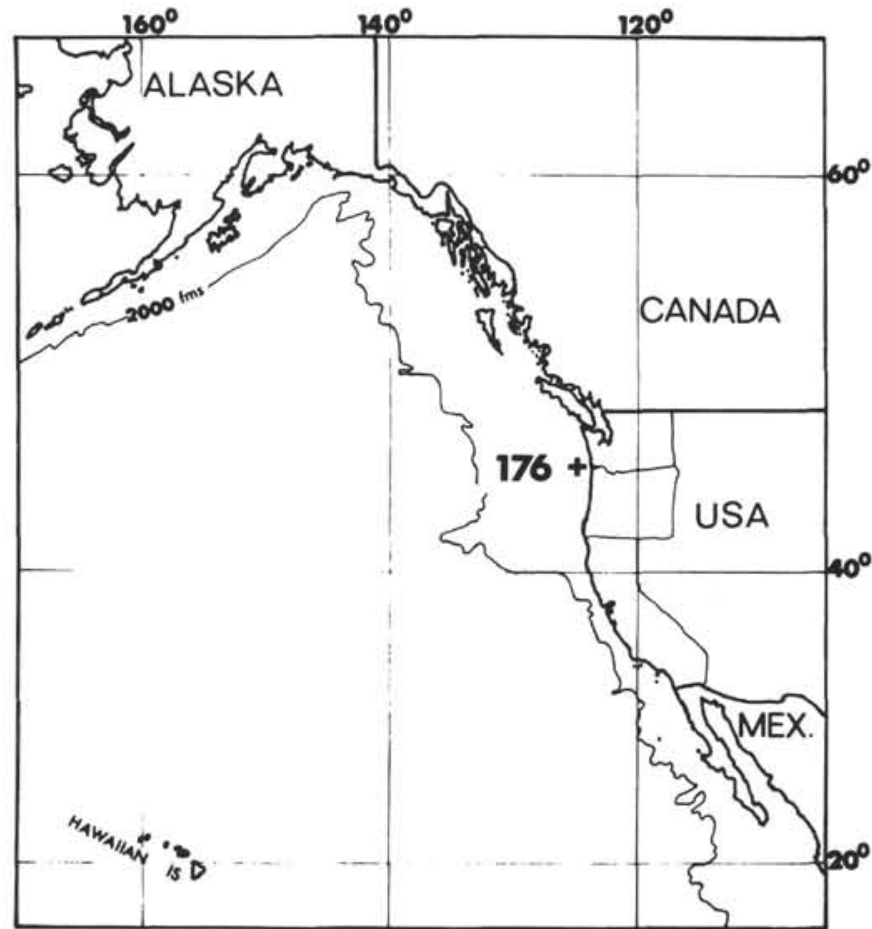

Figure 15. Location of Site 176.
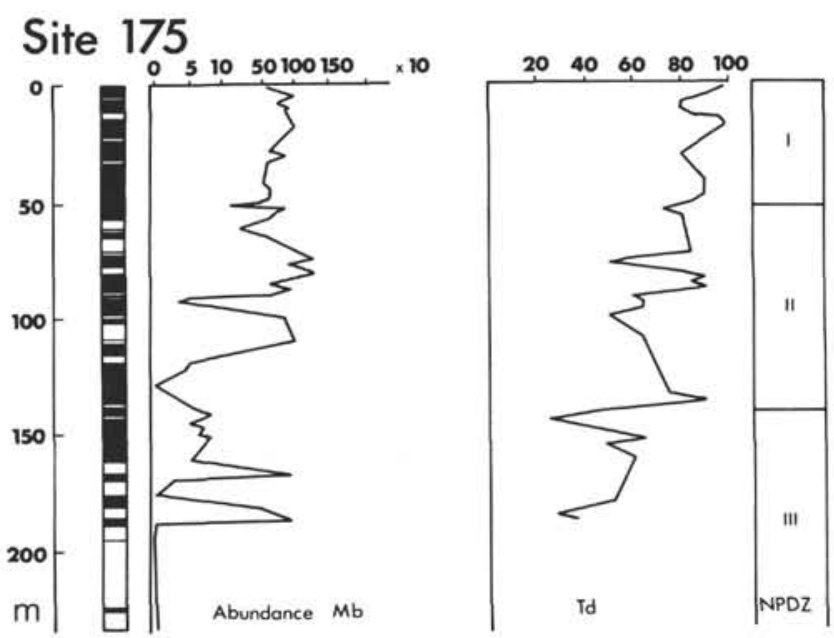

Figure 14. Site 175. Total diatom abundance, Td, and biostratigraphic zonation, versus depth. Recovered intervals black. Abundance determined by Method B.

Site 176

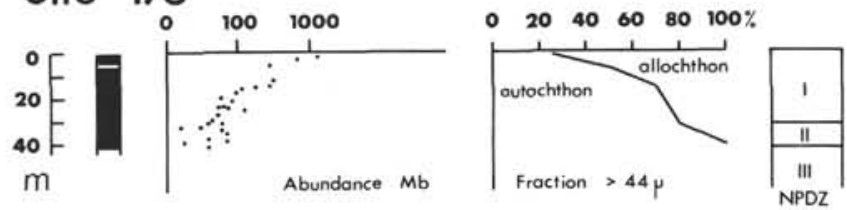

Figure 16. Site 176. Total abundance and displaced floras, versus depth. Recovered intervals black. Abundance determined by Method B. Displaced floras represented by ratio (\%) of autochthonous (marine planktonic) to allochthonous (marine benthonic plus freshwater benthonic and planktonic). Two hundred individuals of the fraction coarser than $44 \mu$ were counted from each core catcher sample.

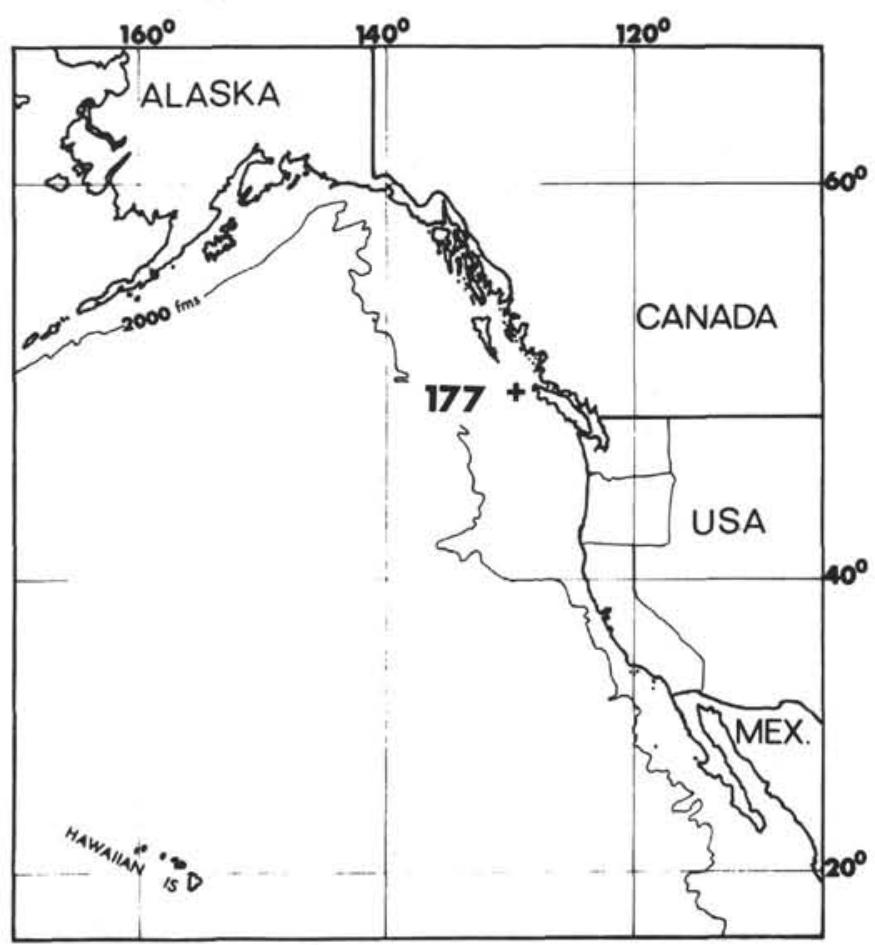

Figure 17. Location of Site 177. 


\section{Site 177}

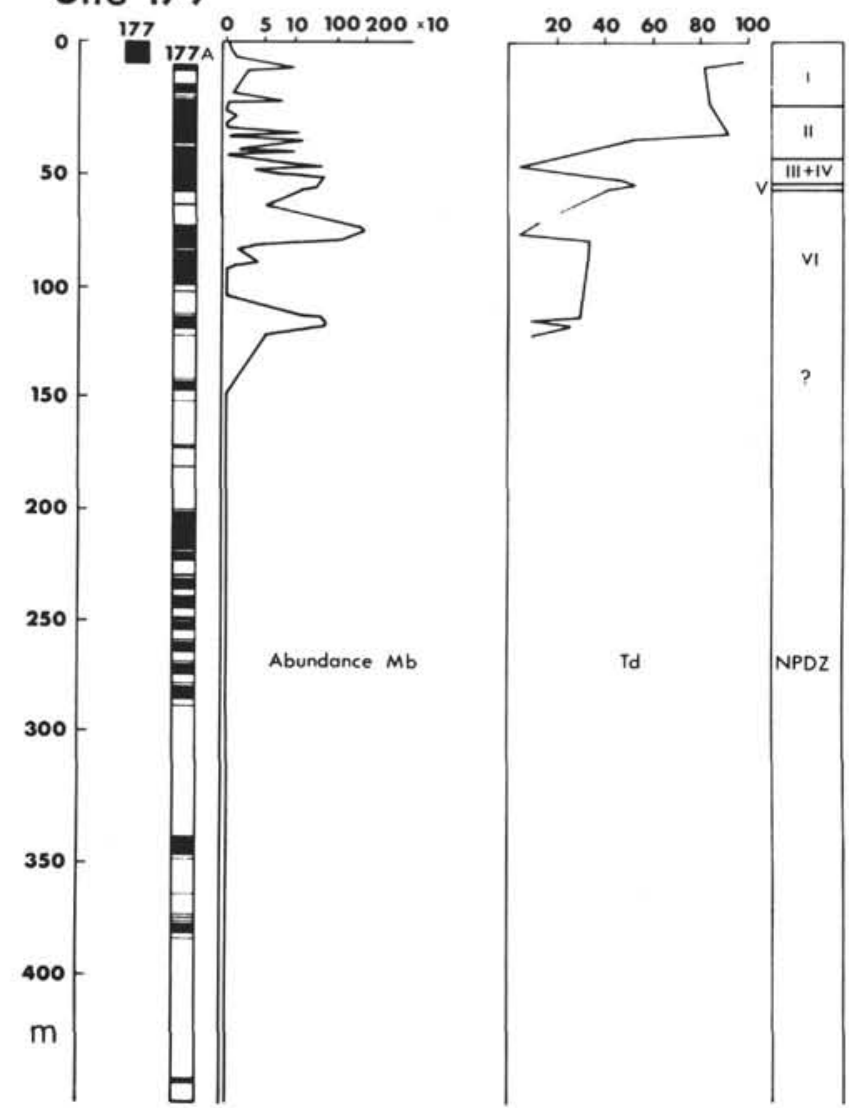

Figure 18. Site 177. Abundance, Td, and zonation, versus depth. Recovered intervals black. Abundance determined by Method B
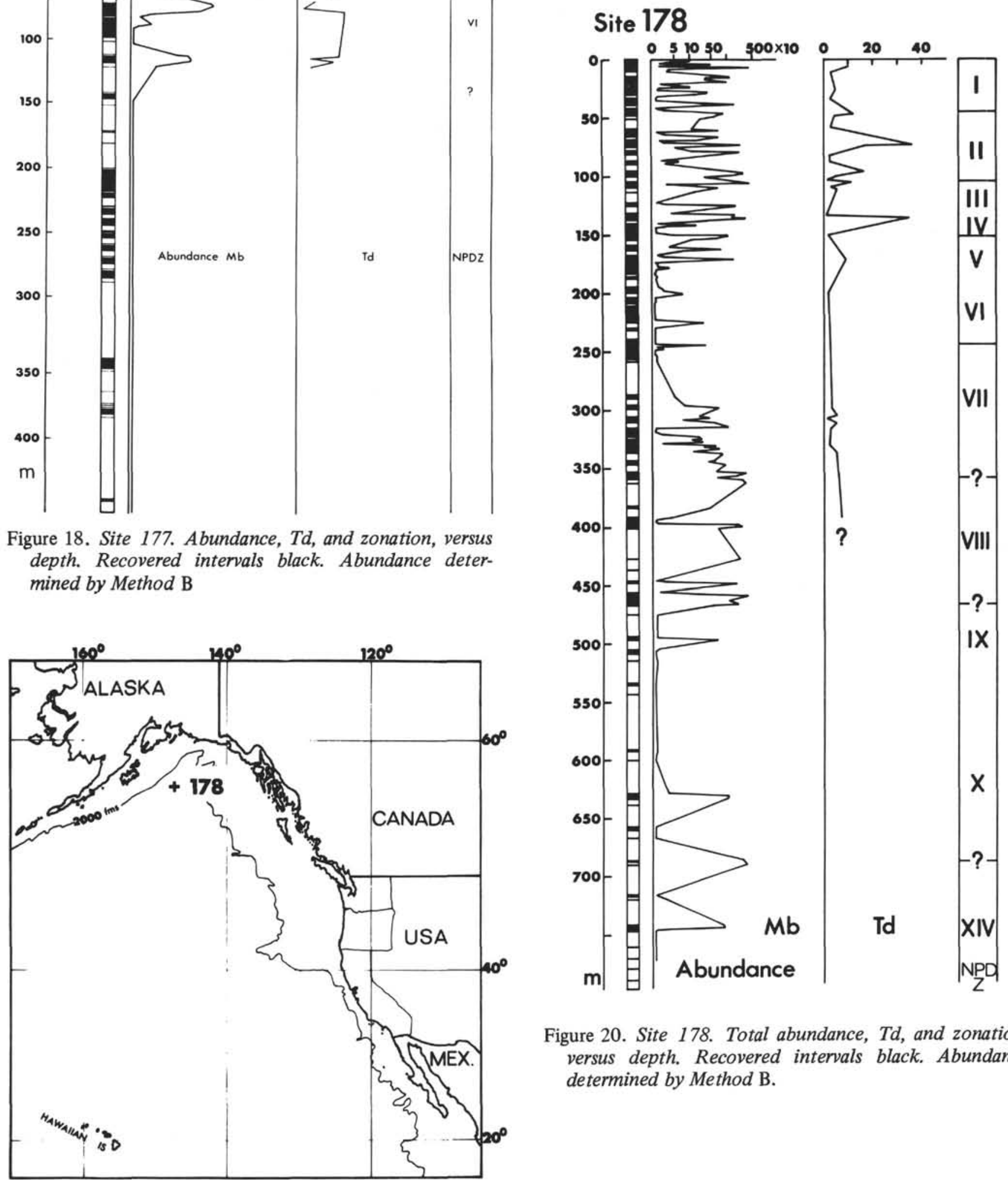

Figure 20. Site 178. Total abundance, Td, and zonation, versus depth. Recovered intervals black. Abundance determined by Method $\mathrm{B}$.

Figure 19. Location of Site 178. 


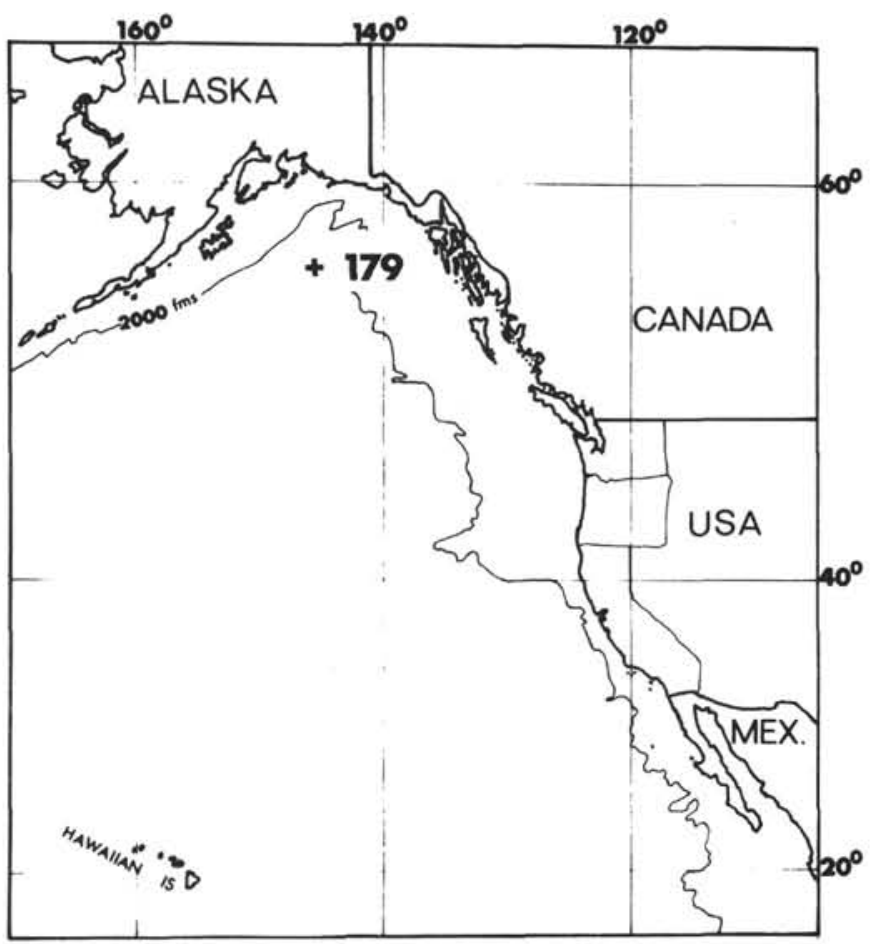

Figure 21. Location of Site 179.

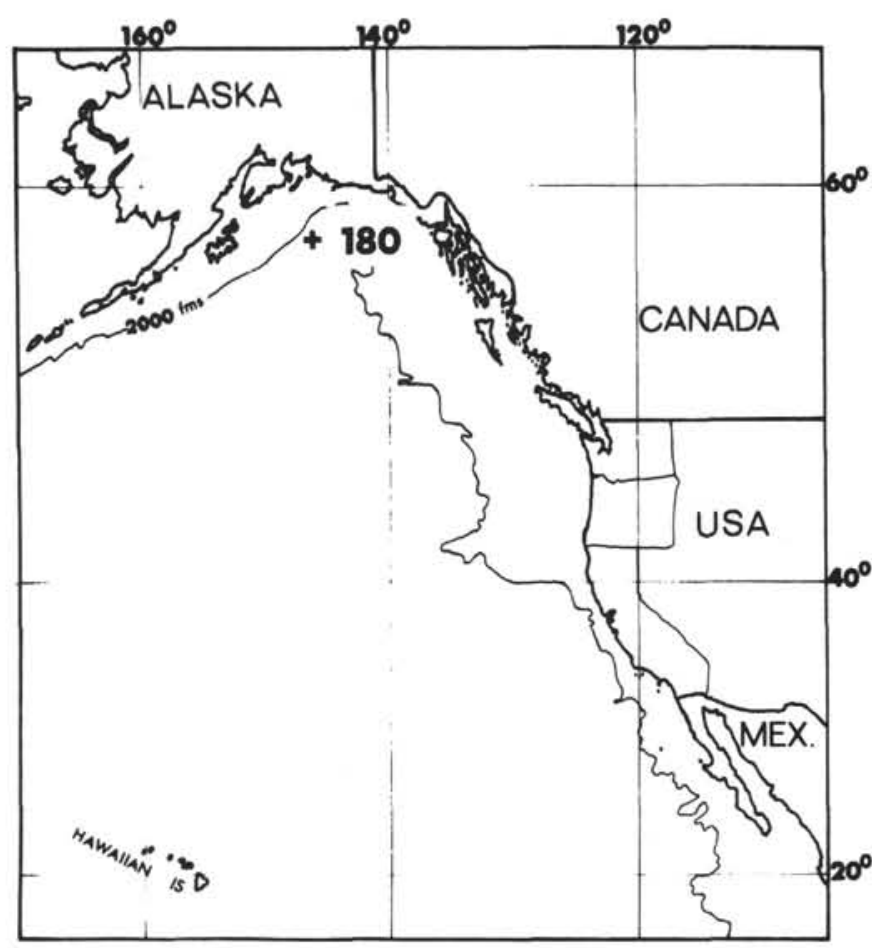

Figure 23. Location of Site 180.
Site 179

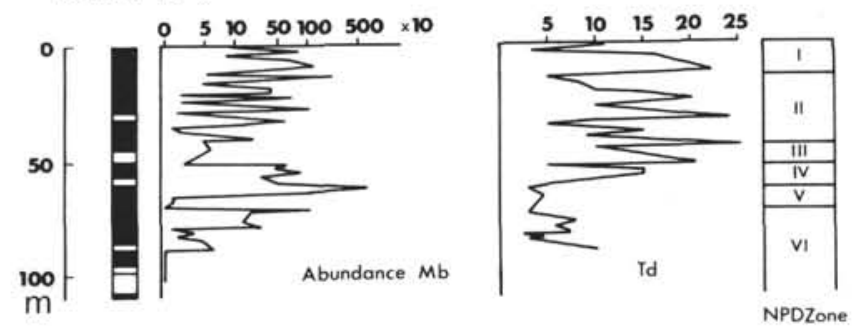

Figure 22. Site 179. Total abundance, Td, and zonation, versus depth. Recovered intervals black. Abundance determined by Method B.

Site 180

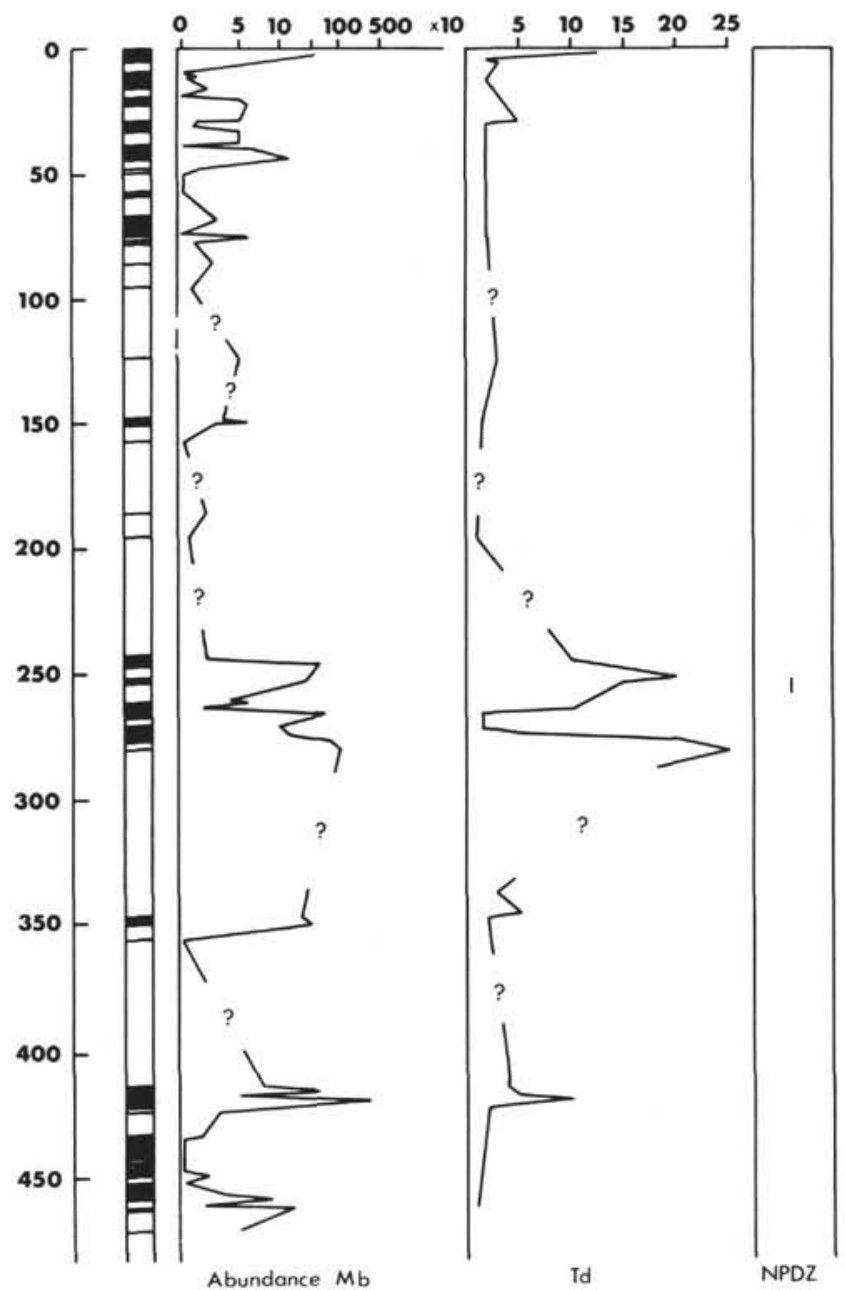
m.

Figure 24. Site 180. Total abundance, Td, and zonation, versus depth. Recovered intervals black. Abundance determined by Method B. 


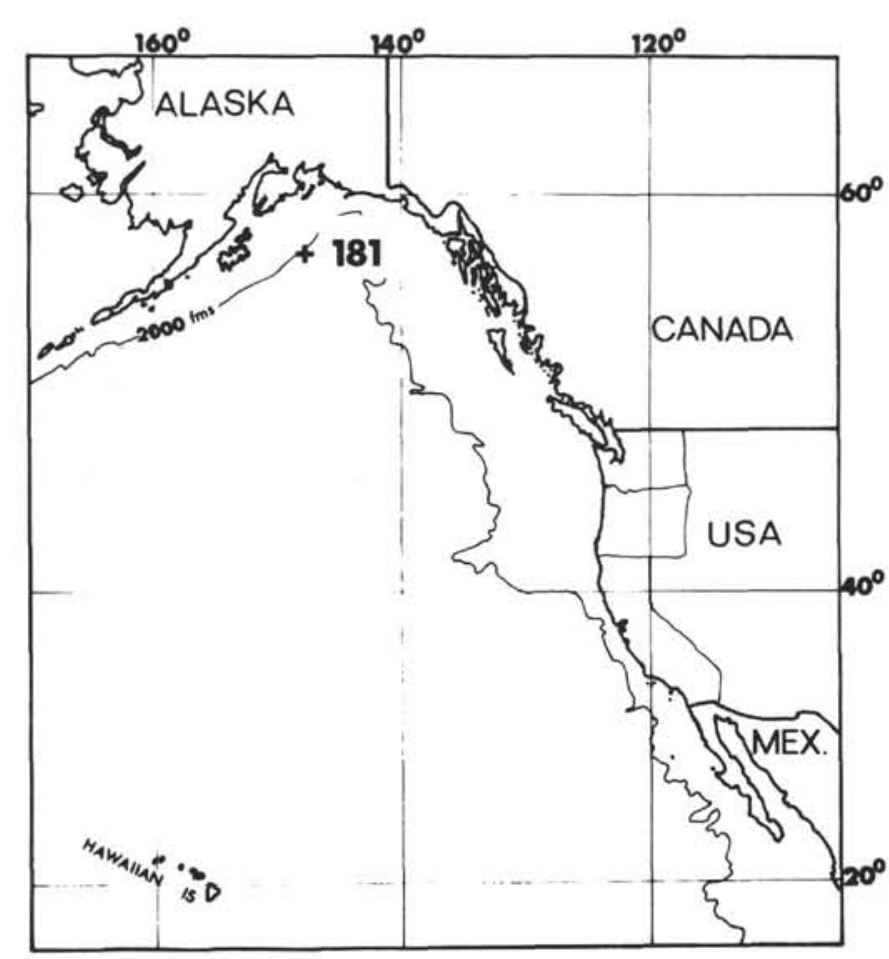

Figure 25. Location of Site 181.

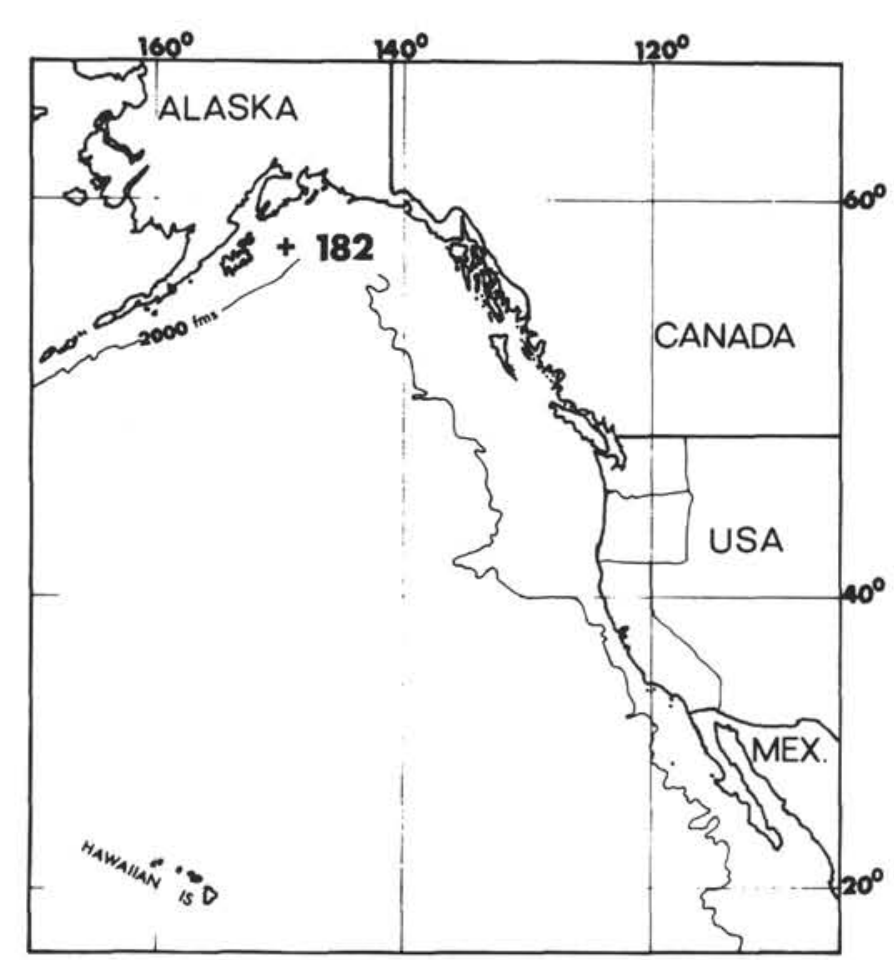

Figure 27. Location of Site 182.

Figure 26. Site 181. Zonation versus depth. Recovered intervals black.

\section{Site 181}

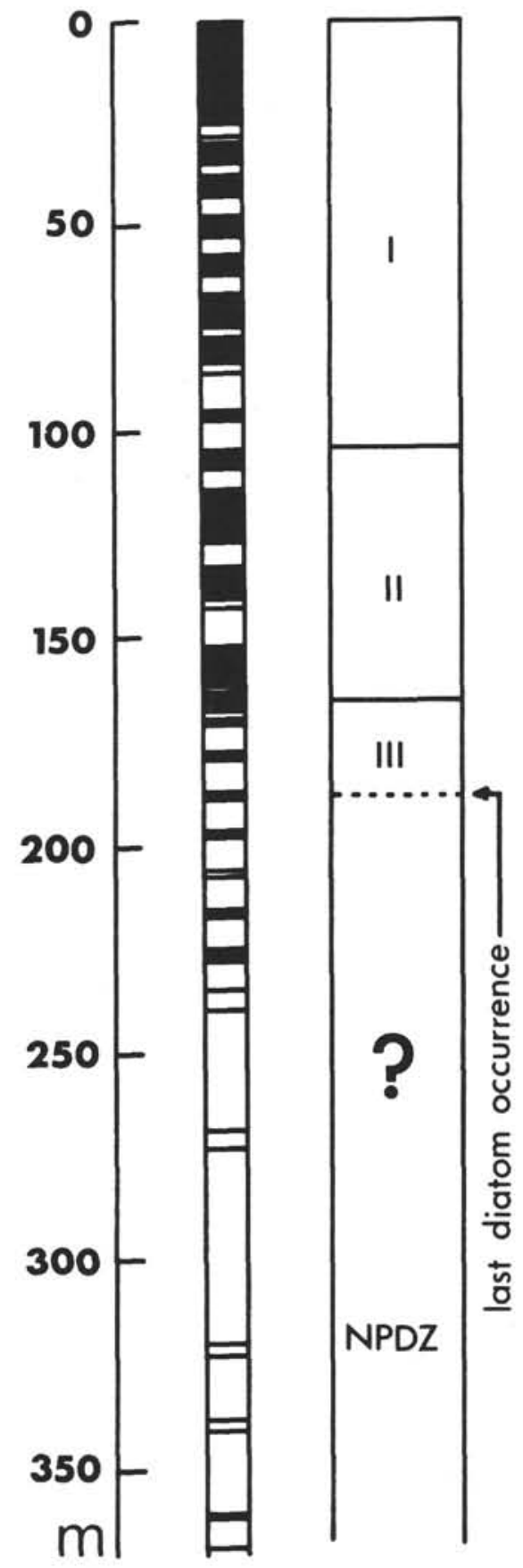


Figure 28. Site 182. Zonation versus depth. Recovered intervals black.

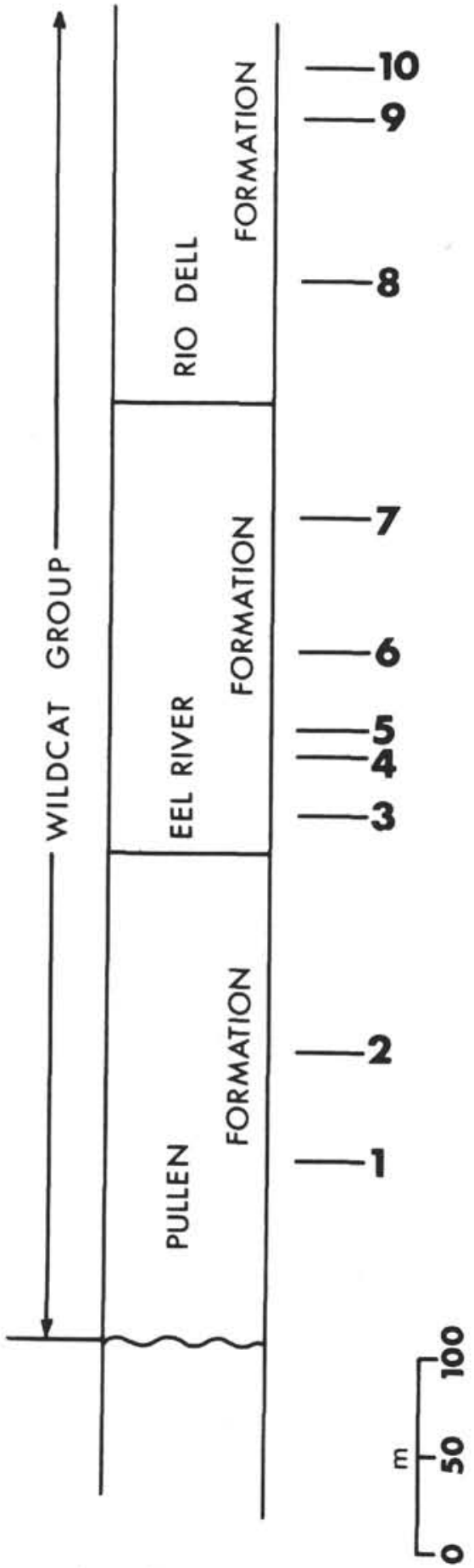

\section{after INGLE (1971)}

Figure 29. Samples 1-10 collected in the Lower Wildcat Group, Mattole Road Area, Humboldt County, California during DSDP Leg 18 postcruise field trip. Stratigraphic position of samples determined by extension of strike and dip (Ingle, personal communication, 1971).
Site 182
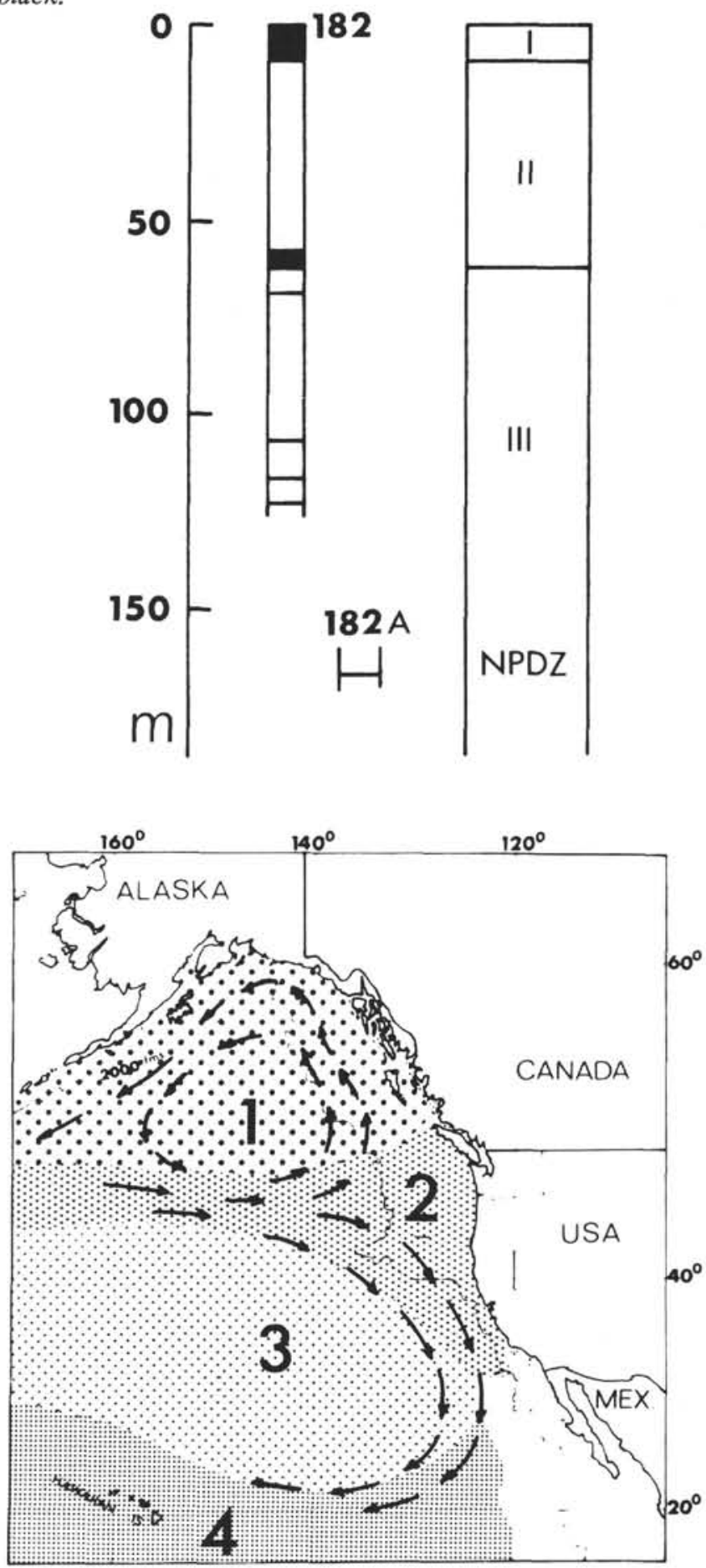

Figure 30. Generalized distribution of four major oceanographic provinces (after Kanaya and Koizumi, 1966) and main current directions in the North Pacific region (after Dodimead et al., 1963; Donahue, 1970): (1) the Alaskan Gyre with the Subarctic Pacific water mass, (2) the Subarctic Current with the Transitional (North and South) Pacific water mass, (3) the Eastern North Pacific Central water mass, and (4) the Pacific Equatorial water mass. 


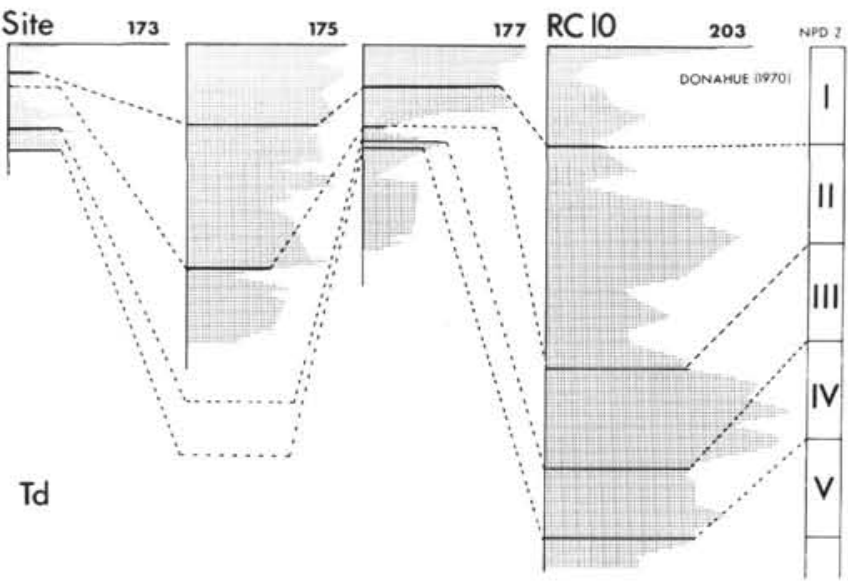

Figure 31. Correlation of Td curves of Sites 173, 175, and 177 with Lamont-Doherty Geological Observatory core RC 10-203 (Donahue, 1970). Correlation based on the lower boundaries of the North Pacific Diatom Zones. Cores located south of $55^{\circ} \mathrm{N}$ latitude.
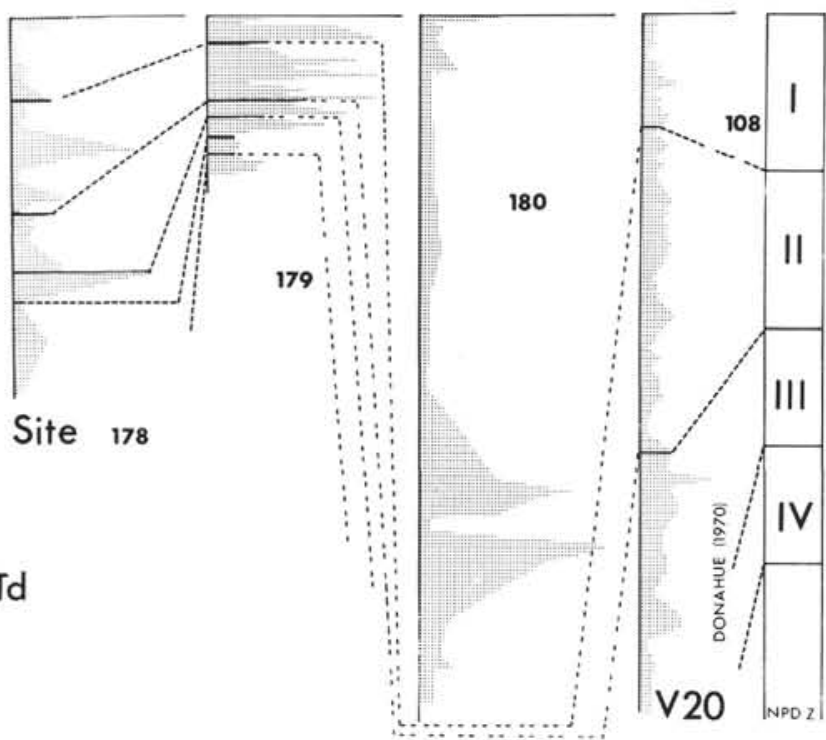

Figure 32. Correlation of Td curves of Sites 178, 179, and 180 with Lamont-Doherty Geological Observatory core V 20-108 (Donahue, 1970). Correlation based on the lower boundaries of the North Pacific Diatom Zones. Cores located north of $45^{\circ} \mathrm{N}$ latitude.

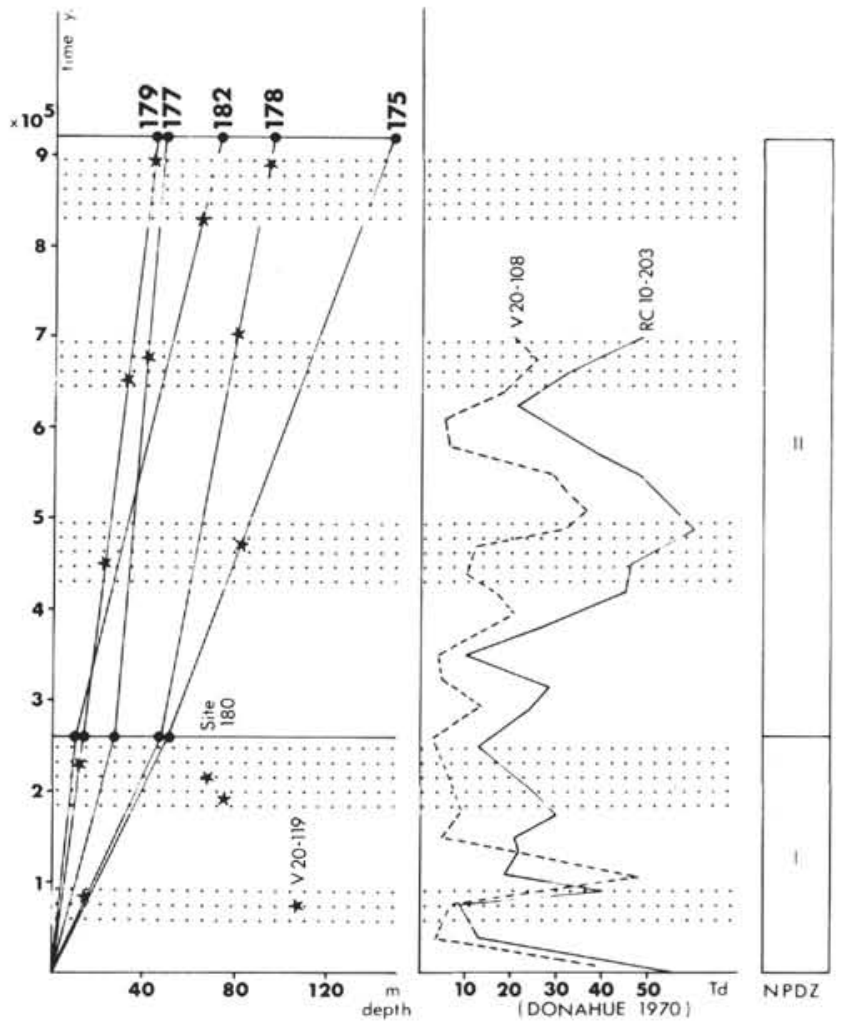

Figure 33. Occurrences of Rhabdonema arcuatum forma ventricosa at different sites for the last 0.9 m.y. B.P. for Sites 175, 177, 178, 179, 180, and 182 and LamontDoherty Geological Observatory core V 20-119 (results from Jouse, 1971 and Donahue, 1970). Heavy dots represent bases of NPD Zones I and II. Stars represent occurrences of Rhabdonema arcuatum forma ventricosa. Data from Site 180 and V 20-119 do not correspond to the depth scale. Stippled areas represent warmer periods. These intervals are compared with Td curves of Donahue (1970) and show good correlation.

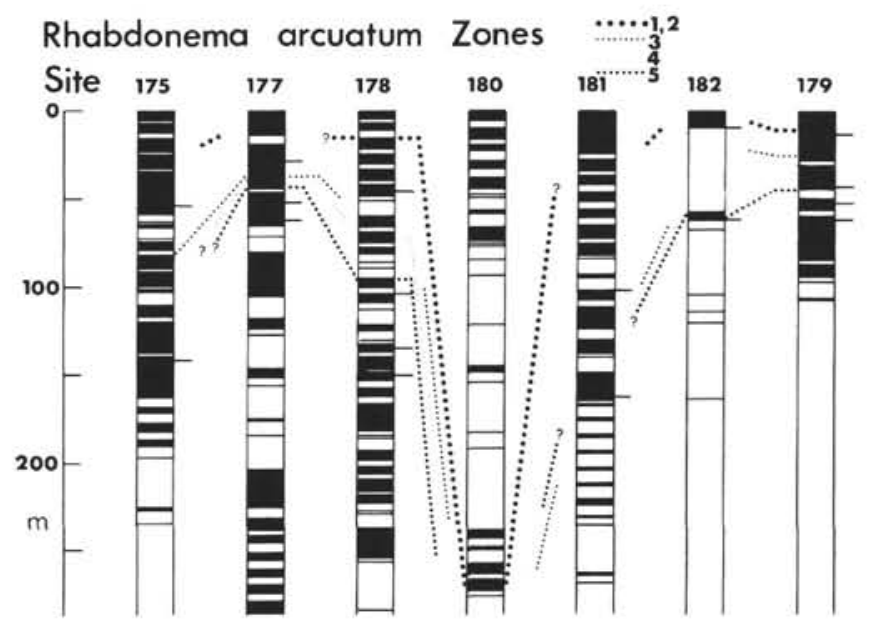

Figure 34. Correlation of Rhabdonema arcuatum Zones at Sites 175, 177, 178, 180,181,182, and 179. Five zones could be revealed: Zones 1 and 2, NPD Zone I; Zones 3, 4, and 5, NPD Zone II. Black areas represent recovered sequences. 


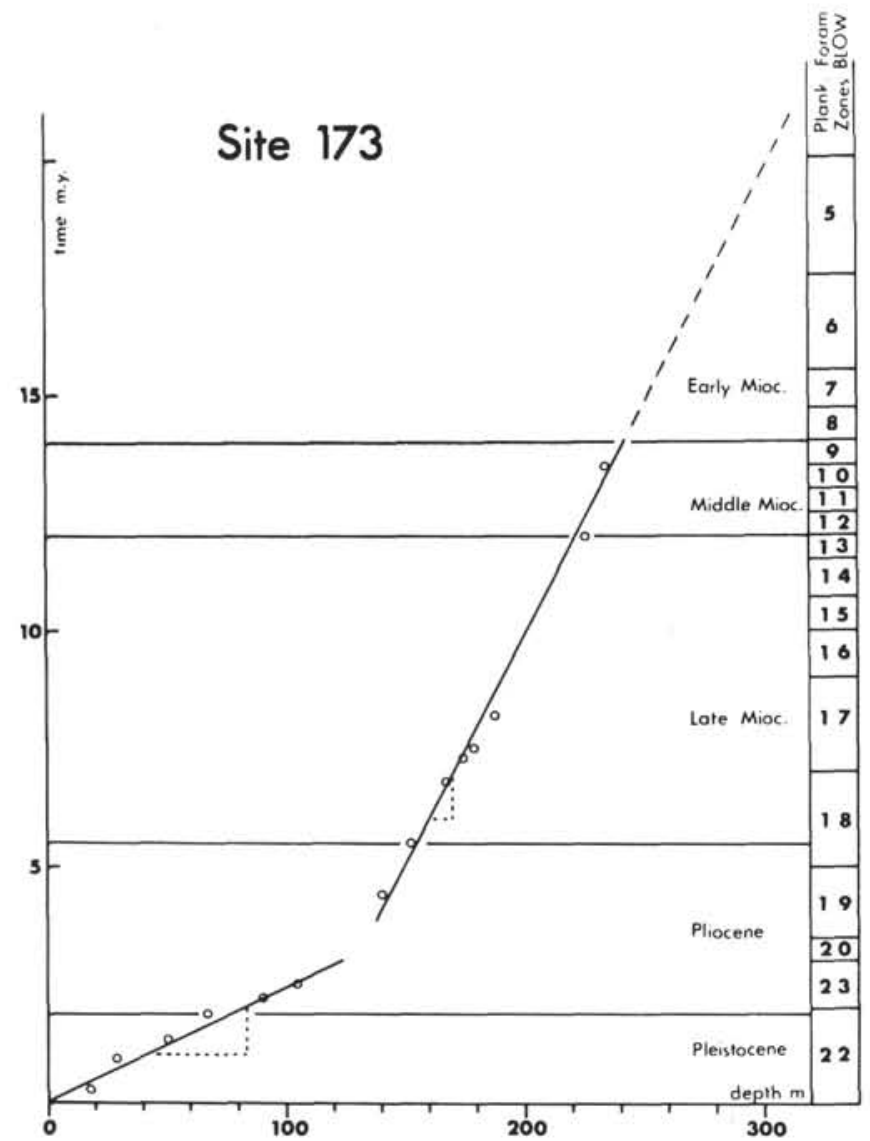

Figure 35. Sedimentation rate at Site 173. Hollow circles indicate absolute ages of North Pacific Diatom Zone boundaries as found at Site 173. Correlation of the Standard Foraminiferal Zones (Blow, 1969) with time Berggren, 1969) was used for all datum planes.

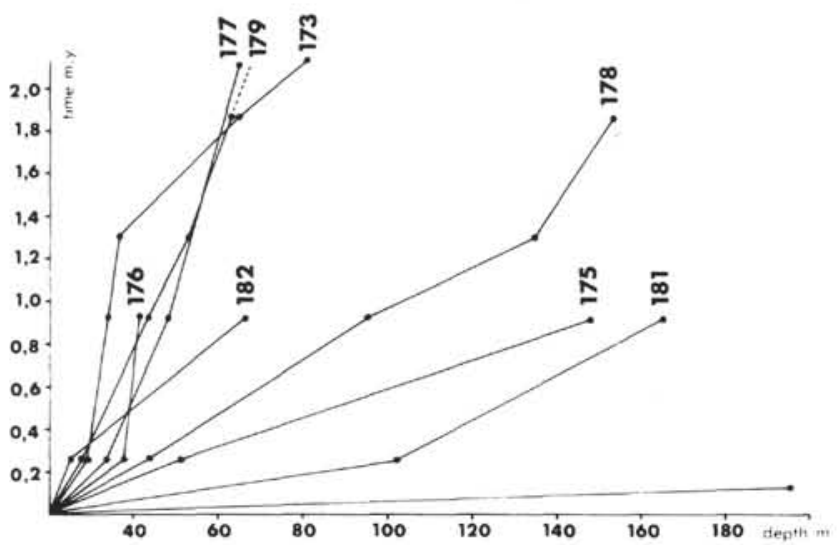

Figure 36. Sedimentation rates of various sites. Age determinations are based on the North Pacific Diatom Zones. 


\section{APPENDIX}

The following lists for each site the abundance $(A=a b u n d a n t$, $\mathrm{C}=$ common, $\mathrm{F}=$ frequent, $\mathrm{R}=$ rare, $\mathrm{B}=$ barren, $-=$ no data available), preservation $(\mathrm{G}=$ good, $\mathrm{M}=$ moderate, $\mathrm{P}=$ poor,$-=$ no data available), of individuals per microscopic field (Method $A$ used only at Site

\begin{tabular}{|c|c|c|c|c|}
\hline Sample & $\begin{array}{l}\text { Abun- } \\
\text { dance }\end{array}$ & $\begin{array}{l}\text { Preser- } \\
\text { vation }\end{array}$ & $\begin{array}{l}\text { Number of } \\
\text { Individuals }\end{array}$ & $\begin{array}{c}\mathrm{Td} \\
\text { Values }\end{array}$ \\
\hline $\begin{array}{l}172-1-1(15-16) \\
172-1-1(20-21) \\
172-1-1(25-26) \\
172-1-1(30-31) \\
172-1-1(40-41) \\
172-1-1(45-46) \\
172-1-2(80-81) \\
172-1-3(80-81) \\
172-1-4(80-81) \\
172-1-5(80-81)\end{array}$ & $\begin{array}{l}\text { B } \\
\text { B } \\
\text { B } \\
\text { B } \\
\text { B } \\
\text { B } \\
\text { B } \\
\text { B } \\
\text { B } \\
\text { B }\end{array}$ & & & \\
\hline $\begin{array}{l}172-1-6(80-82) \\
172-1(C C) \\
172-2-1(10-11) \\
172-2-1(15-16) \\
172-2-1(19-20) \\
172-2-1(25-26) \\
172-2-1(30-31) \\
172-2-1(36-37) \\
172-2-2(80-81) \\
172-2-3(80-81)\end{array}$ & $\begin{array}{l}\text { B } \\
\text { B } \\
\text { B } \\
\text { B } \\
\text { B } \\
\text { B } \\
\text { B } \\
\text { B } \\
\text { B } \\
\text { B }\end{array}$ & & & \\
\hline $\begin{array}{l}172-2-4(80-81) \\
172-2-5(13-14) \\
172-2-5(73-74) \\
172-2-5(80-81) \\
172-2-6(80-81) \\
172-2(C C) \\
172-3-2(80-81) \\
172-3-3(80-81) \\
172-3-4(53-54) \\
172-3-4(80-81)\end{array}$ & $\begin{array}{l}\text { B } \\
\text { B } \\
\text { B } \\
\text { B } \\
\text { B } \\
\text { B } \\
\text { B } \\
\text { B } \\
\text { B } \\
\text { B }\end{array}$ & & & \\
\hline $\begin{array}{l}172-3-5(80-81) \\
172-3-6(8-9) \\
172-3-6(144-145) \\
172-3(\mathrm{CC})\end{array}$ & $\begin{array}{l}\text { B } \\
\text { B } \\
\text { B } \\
\text { B }\end{array}$ & & & \\
\hline $\begin{array}{l}173-1-1(110-111) \\
173-1-2(43-44) \\
173-1-2(109-111) \\
173-1-3(43-44) \\
173-1-3(105-106) \\
173-1-4(55-56) \\
173-1-4(114-116) \\
173-1(C C) \\
173-2-1(43-44) \\
173-2-1(103-104)\end{array}$ & $\begin{array}{l}\text { C } \\
\text { C } \\
\text { C } \\
\text { C } \\
\text { C } \\
\text { A } \\
\text { A } \\
\text { C } \\
\text { C } \\
\text { C }\end{array}$ & $\begin{array}{l}\text { G } \\
\text { G } \\
\text { G } \\
\text { G } \\
\text { G } \\
\text { G } \\
\text { G } \\
\text { G } \\
\text { G } \\
\text { G }\end{array}$ & $\begin{array}{l}5 \\
3 \\
2 \\
3 \\
3 \\
9 \\
8 \\
2 \\
3 \\
3\end{array}$ & $\begin{array}{r}80 \\
2 \\
2 \\
2 \\
1 \\
2 \\
3 \\
- \\
3 \\
4\end{array}$ \\
\hline $\begin{array}{l}173-2-2(43-44) \\
173-2-2(104-106) \\
173-2-3(38-39) \\
173-2-3(117-118) \\
173-2-4(42-43) \\
173-2-4(104-105) \\
173-2-5(63-64) \\
173-2-6(55-56) \\
173-3-1(43-44) \\
173-3-2(55-56)\end{array}$ & $\begin{array}{l}\mathrm{C} \\
\mathrm{C} \\
\mathrm{R} \\
\mathrm{C} \\
\mathrm{C} \\
\mathrm{C} \\
\mathrm{C} \\
\mathrm{R} \\
\mathrm{C} \\
\mathrm{C}\end{array}$ & $\begin{array}{l}\text { G } \\
G \\
M \\
G \\
G \\
G \\
G \\
G \\
G \\
G\end{array}$ & $\begin{array}{l}4 \\
2 \\
1 \\
3 \\
4 \\
5 \\
4 \\
1 \\
2 \\
3\end{array}$ & $\begin{array}{r}2 \\
3 \\
- \\
3 \\
20 \\
10 \\
20 \\
20 \\
4 \\
16\end{array}$ \\
\hline $\begin{array}{l}173-3-3(104-106) \\
173-3-4(109-110) \\
173-3-5(55-56) \\
173-3-6(56-57) \\
173-4-1(54-55) \\
173-4-2(55-56) \\
173-4-3(55-56) \\
173-4-4(55-56) \\
173-4-5(55-56) \\
173-5-1(118-119)\end{array}$ & $\begin{array}{l}\mathrm{C} \\
\mathrm{C} \\
\mathrm{R} \\
\mathrm{C} \\
\mathrm{C} \\
\mathrm{A} \\
\mathrm{A} \\
\mathrm{A} \\
\mathrm{C} \\
\mathrm{A}\end{array}$ & $\begin{array}{l}\mathrm{G} \\
\mathrm{G} \\
\mathrm{G} \\
\mathrm{G} \\
\mathrm{G} \\
\mathrm{G} \\
\mathrm{G} \\
\mathrm{G} \\
\mathrm{G} \\
\mathrm{G}\end{array}$ & $\begin{array}{l}4 \\
2 \\
0 \\
2 \\
3 \\
9 \\
7 \\
7 \\
3 \\
9\end{array}$ & $\begin{array}{r}10 \\
40 \\
41 \\
2 \\
2 \\
8 \\
7 \\
10 \\
2 \\
8\end{array}$ \\
\hline $\begin{array}{l}173-5-2(55-56) \\
173-5-3(55-56) \\
\end{array}$ & $\begin{array}{l}\mathrm{R} \\
\mathrm{R} \\
\end{array}$ & $\begin{array}{l}\mathrm{G} \\
\mathrm{G}\end{array}$ & $\begin{array}{l}1 \\
1 \\
\end{array}$ & $\begin{array}{r}8 \\
- \\
\end{array}$ \\
\hline
\end{tabular}

173, Method $B$ used at the other sites), and Td values. For more details see the sections in this chapter entitled "Diatoms at Each Site" and "Paleoclimatic Interpretation." Note the different Td values caused by the use of different indicator species as pointed out under each site in the section on paleoclimatic interpretation.

\begin{tabular}{|c|c|c|c|c|}
\hline Sample & $\begin{array}{l}\text { Abun- } \\
\text { dance }\end{array}$ & $\begin{array}{l}\text { Preser- } \\
\text { vation }\end{array}$ & $\begin{array}{l}\text { Number of } \\
\text { Individuals }\end{array}$ & $\begin{array}{c}\text { Td } \\
\text { Value }\end{array}$ \\
\hline $\begin{array}{l}173-5-4(55-56) \\
173-5-5(55-56) \\
173-6-1(105-106) \\
173-6-2(55-56) \\
173-6-3(55-56) \\
173-7-1(67-68) \\
173-7-2(55-56) \\
173-7-3(55-56)\end{array}$ & $\begin{array}{l}\text { C } \\
\text { C } \\
\text { A } \\
\text { C } \\
\text { C } \\
\text { C } \\
\text { C } \\
\text { C }\end{array}$ & $\begin{array}{l}G \\
G \\
G \\
G \\
G \\
G \\
G \\
G\end{array}$ & $\begin{array}{l}3 \\
3 \\
9 \\
4 \\
6 \\
5 \\
4 \\
3\end{array}$ & $\begin{array}{r}2 \\
4 \\
58 \\
20 \\
10 \\
30 \\
45 \\
10\end{array}$ \\
\hline $\begin{array}{l}173-7-4(55-56) \\
173-8-1(60-61) \\
173-8-2(55-56) \\
173-8-3(55-56) \\
173-8-4(55-56) \\
173-8-5(55-56) \\
173-8-6(55-56) \\
173-8(C C) \\
173-9-1(55-56) \\
173-9-2(55-56)\end{array}$ & $\begin{array}{l}\mathrm{C} \\
\mathrm{C} \\
\mathrm{R} \\
\mathrm{C} \\
\mathrm{C} \\
\mathrm{C} \\
\mathrm{C} \\
\mathrm{C} \\
\mathrm{C} \\
\mathrm{C}\end{array}$ & $\begin{array}{l}\text { G } \\
\text { G } \\
M \\
G \\
G \\
G \\
G \\
G \\
G \\
G\end{array}$ & $\begin{array}{l}4 \\
4 \\
1 \\
3 \\
3 \\
3 \\
4 \\
4 \\
2 \\
3\end{array}$ & $\begin{array}{l}30 \\
40 \\
- \\
- \\
- \\
70 \\
39 \\
- \\
39 \\
15\end{array}$ \\
\hline $\begin{array}{l}173-9-3(55-56) \\
173-9-4(82-83) \\
173-9-5(55-56) \\
173-9-6(55-56) \\
173-9(C C) \\
173-10-1(55-56) \\
173-10-2(55-56) \\
173-10-3(55-56) \\
173-10-4(55-56) \\
173-10-5(55-56)\end{array}$ & $\begin{array}{l}\text { C } \\
\text { C } \\
\text { C } \\
\text { A } \\
\text { A } \\
\text { A } \\
\text { A } \\
\text { A } \\
\text { A } \\
\text { A }\end{array}$ & $\begin{array}{l}\mathrm{G} \\
\mathrm{G} \\
\mathrm{G} \\
\mathrm{G} \\
\mathrm{G} \\
\mathrm{G} \\
\mathrm{G} \\
\mathrm{G} \\
\mathrm{G} \\
\mathrm{G}\end{array}$ & $\begin{array}{r}4 \\
3 \\
4 \\
12 \\
12 \\
11 \\
9 \\
7 \\
9 \\
7\end{array}$ & $\begin{array}{r}25 \\
\overline{5} \\
34 \\
\overline{27} \\
10 \\
12 \\
33 \\
29\end{array}$ \\
\hline $\begin{array}{l}173-10-6(55-56) \\
173-10 \text { (EP) } \\
173-11-1(55-56) \\
173-11-2(55-56) \\
173-11-3(55-56) \\
173-11-4(55-56) \\
173-11(\mathrm{EP}) \\
173-12-1(55-56) \\
173-12-2(55-56) \\
173-12-3(55-56)\end{array}$ & $\begin{array}{l}\text { A } \\
\text { A } \\
\text { A } \\
\text { A } \\
\text { A } \\
\text { A } \\
\text { A } \\
\text { A } \\
\text { A } \\
\text { A }\end{array}$ & $\begin{array}{l}\text { G } \\
G \\
G \\
G \\
G \\
G \\
G \\
G \\
G \\
G\end{array}$ & $\begin{array}{r}4 \\
4 \\
8 \\
9 \\
7 \\
12 \\
12 \\
9 \\
5 \\
9\end{array}$ & $\begin{array}{r}8 \\
- \\
5 \\
19 \\
10 \\
49 \\
- \\
46 \\
58 \\
48\end{array}$ \\
\hline $\begin{array}{l}173-12-4(55-56) \\
173-12-5(63-64) \\
173-12-6(55-56) \\
173-12(C C) \\
173-13-1(55-56) \\
173-13-2(55-56) \\
173-13-3(55-56) \\
173-13-4(55-56) \\
173-13-5(55-56) \\
173-13-6(55-56)\end{array}$ & $\begin{array}{l}\text { A } \\
\text { A } \\
\text { A } \\
\text { A } \\
\text { A } \\
\text { A } \\
\text { A } \\
\text { A } \\
\text { A } \\
\text { A }\end{array}$ & $\begin{array}{l}\mathrm{G} \\
\mathrm{G} \\
\mathrm{G} \\
\mathrm{G} \\
\mathrm{G} \\
\mathrm{G} \\
\mathrm{G} \\
\mathrm{G} \\
\mathrm{G} \\
\mathrm{G}\end{array}$ & $\begin{array}{l}6 \\
8 \\
4 \\
4 \\
5 \\
3 \\
6 \\
6 \\
6 \\
6 \\
5\end{array}$ & $\begin{array}{l}23 \\
14 \\
44 \\
- \\
27 \\
27 \\
30 \\
23 \\
23 \\
-\end{array}$ \\
\hline $\begin{array}{l}173-13(\mathrm{CC}) \\
173-14-1(55-56) \\
173-14-2(95-96) \\
173-14-3(55-56) \\
173-14 \\
173-15-2(55-56) \\
173-15-3(55-56) \\
173-15-4(55-56) \\
173-15(\mathrm{CC}) \\
173-16-1(69-70)\end{array}$ & $\begin{array}{l}\text { A } \\
\text { A } \\
\text { A } \\
\text { A } \\
\text { A } \\
\text { A } \\
\text { A } \\
\text { A } \\
\text { A } \\
\text { A }\end{array}$ & $\begin{array}{l}\mathrm{G} \\
\mathrm{G} \\
\mathrm{G} \\
\mathrm{G} \\
\mathrm{G} \\
\mathrm{G} \\
\mathrm{G} \\
\mathrm{G} \\
\mathrm{G} \\
\mathrm{G}\end{array}$ & $\begin{array}{r}6 \\
7 \\
7 \\
20 \\
20 \\
24 \\
21 \\
20 \\
19 \\
18\end{array}$ & $\begin{array}{l}\overline{39} \\
28 \\
30 \\
- \\
- \\
- \\
- \\
-\end{array}$ \\
\hline $\begin{array}{l}173-16-2(55-56) \\
173-16-3(55-56) \\
173-16(\mathrm{CC}) \\
173-17-2(55-56) \\
173-17-3(55-57) \\
173-17-3(103-104) \\
173-17(\mathrm{CC}) \\
173-18-2(55-56) \\
173-18-3(56-57) \\
173-18-4(56-57) \\
\end{array}$ & $\begin{array}{l}\text { A } \\
\text { A } \\
\text { A } \\
\text { A } \\
\text { A } \\
\text { A } \\
\text { A } \\
\text { A } \\
\text { A } \\
\text { A }\end{array}$ & $\begin{array}{l}\mathrm{G} \\
\mathrm{G} \\
\mathrm{G} \\
\mathrm{G} \\
\mathrm{G} \\
\mathrm{G} \\
\mathrm{G} \\
\mathrm{G} \\
\mathrm{G} \\
\mathrm{G}\end{array}$ & $\begin{array}{l}19 \\
20 \\
20 \\
24 \\
20 \\
15 \\
10 \\
11 \\
10 \\
11\end{array}$ & $\begin{array}{l}- \\
- \\
- \\
-\end{array}$ \\
\hline
\end{tabular}




\begin{tabular}{|c|c|c|c|c|}
\hline Sample & $\begin{array}{l}\text { Abun- } \\
\text { dance }\end{array}$ & $\begin{array}{l}\text { Preser- } \\
\text { vation }\end{array}$ & $\begin{array}{l}\text { Number of } \\
\text { Individuals }\end{array}$ & $\begin{array}{c}\text { Td } \\
\text { Values }\end{array}$ \\
\hline $\begin{array}{l}173-18-5(55-56) \\
173-18(\mathrm{CC}) \\
173-19-2(55-56) \\
173-19-4(55-56) \\
173-19(\mathrm{CC}) \\
173-20-2(55-56) \\
173-20-3(55-56) \\
173-20(\mathrm{CC}) \\
173-21-1(55-56) \\
173-21-1(99-100)\end{array}$ & $\begin{array}{l}\text { A } \\
\text { A } \\
\text { A } \\
\text { A } \\
\text { A } \\
\text { A } \\
\text { A } \\
\text { A } \\
\text { A } \\
\text { A }\end{array}$ & $\begin{array}{l}\mathrm{G} \\
\mathrm{G} \\
\mathrm{G} \\
\mathrm{G} \\
\mathrm{G} \\
\mathrm{G} \\
\mathrm{G} \\
\mathrm{G} \\
\mathrm{G} \\
\mathrm{G}\end{array}$ & $\begin{array}{r}9 \\
10 \\
15 \\
12 \\
11 \\
10 \\
15 \\
15 \\
13 \\
12\end{array}$ & \\
\hline $\begin{array}{l}173-21-3(55-56) \\
173-21-4(55-56) \\
173-21(C C) \\
173-22-1(101-102) \\
173-22-2(55-56) \\
173-22-3(55-56) \\
173-22-4(55-56) \\
173-22-5(52-53) \\
173-22(C C) \\
173-23-1(110-111)\end{array}$ & $\begin{array}{l}\text { A } \\
\text { A } \\
\text { A } \\
\text { A } \\
\text { A } \\
\text { A } \\
\text { A } \\
\text { A } \\
\text { A } \\
\text { A }\end{array}$ & $\begin{array}{l}\text { G } \\
G \\
G \\
G \\
G \\
G \\
G \\
G \\
G \\
G\end{array}$ & $\begin{array}{l}10 \\
20 \\
21 \\
19 \\
12 \\
15 \\
15 \\
15 \\
15 \\
13\end{array}$ & \\
\hline $\begin{array}{l}173-23-2(55-56) \\
173-23-3(55-56) \\
173-23(C C) \\
173-24-1(105-106) \\
173-24-2(55-56) \\
173-24-3(55-56) \\
173-24-4(55-56) \\
173-24-5(55-56) \\
173-24(C C) \\
173-25-1(95-96)\end{array}$ & $\begin{array}{l}\text { A } \\
\text { A } \\
\text { A } \\
\text { A } \\
\text { A } \\
\text { A } \\
\text { A } \\
\text { A } \\
\text { A } \\
\text { A }\end{array}$ & $\begin{array}{l}\mathrm{G} \\
\mathrm{G} \\
\mathrm{G} \\
\mathrm{G} \\
\mathrm{G} \\
\mathrm{G} \\
\mathrm{G} \\
\mathrm{G} \\
\mathrm{G} \\
\mathrm{G}\end{array}$ & $\begin{array}{l}15 \\
16 \\
16 \\
15 \\
15 \\
17 \\
12 \\
12 \\
12 \\
15\end{array}$ & \\
\hline $\begin{array}{l}173-25-2(55-56) \\
173-25-3(55-56) \\
173-25-4(55-56) \\
173-25-5(45-46) \\
173-25(C C) \\
173-26-1(120-121) \\
173-26-2(52-53) \\
173-26-3(55-56) \\
173-26-4(55-56) \\
173-26(C C)\end{array}$ & $\begin{array}{l}\text { A } \\
\text { A } \\
\text { A } \\
\text { A } \\
\text { A } \\
\text { A } \\
\text { A } \\
\text { A } \\
\text { A } \\
\text { A }\end{array}$ & $\begin{array}{l}\text { G } \\
G \\
G \\
G \\
G \\
G \\
G \\
G \\
G \\
G \\
G\end{array}$ & $\begin{array}{r}16 \\
17 \\
16 \\
10 \\
8 \\
16 \\
16 \\
11 \\
11 \\
9 \\
9\end{array}$ & \\
\hline $\begin{array}{l}173-27-1(107-108) \\
173-27-2(55-56) \\
173-27-3(55-56) \\
173-27-4(55-56) \\
173-27(\mathrm{CC}) \\
173-28-1(100-101) \\
173-28-2(44-45) \\
173-28-3(55-56) \\
173-28(\mathrm{CC}) \\
173-29-1(55-56)\end{array}$ & $\begin{array}{l}\text { A } \\
\text { A } \\
\text { A } \\
\text { A } \\
\text { A } \\
\text { A } \\
\text { A } \\
\text { A } \\
\text { A } \\
\text { A }\end{array}$ & $\begin{array}{l}\text { G } \\
\text { G } \\
G \\
G \\
G \\
G \\
G \\
G \\
G \\
G\end{array}$ & $\begin{array}{l}11 \\
10 \\
15 \\
10 \\
10 \\
10 \\
19 \\
18 \\
19 \\
17\end{array}$ & \\
\hline $\begin{array}{l}173-29-2(57-59) \\
173-29(\mathrm{CC}) \\
173-30(\mathrm{CC}) \\
173-31-1(132-134) \\
173-32(\mathrm{CC}) \\
173-34-1(130-131) \\
173-34-3(74-75) \\
173-34-3(55-57) \\
173-34(\mathrm{CC}) \\
173-35-1(128-129)\end{array}$ & $\begin{array}{l}\text { A } \\
\text { A } \\
\text { A } \\
\text { C } \\
\text { B } \\
\text { B } \\
\text { B } \\
\text { B } \\
\text { B } \\
\text { B }\end{array}$ & $\begin{array}{l}\text { G } \\
\text { G } \\
\text { G } \\
\text { M } \\
- \\
- \\
- \\
- \\
-\end{array}$ & $\begin{array}{r}15 \\
21 \\
12 \\
3 \\
0 \\
0 \\
0 \\
0 \\
0 \\
0\end{array}$ & \\
\hline $\begin{array}{l}173-35-2(55-56) \\
173-35-3(18-19) \\
173-35(\mathrm{CC}) \\
173-36(\mathrm{CC}) \\
173-37(\mathrm{CC}) \\
173-38 \text { [basement] }\end{array}$ & $\begin{array}{l}\text { B } \\
\text { B } \\
\text { B } \\
\text { B } \\
\text { B } \\
\text { B }\end{array}$ & $\begin{array}{l}- \\
- \\
- \\
- \\
-\end{array}$ & $\begin{array}{l}0 \\
0 \\
0 \\
0 \\
0 \\
0\end{array}$ & \\
\hline $\begin{array}{l}174-1(\mathrm{CC}) \\
174-2(\mathrm{CC}) \\
174-3(\mathrm{CC}) \\
174 \mathrm{~A}-1(\mathrm{CC})\end{array}$ & $\begin{array}{l}\mathrm{C} \\
\mathrm{R} \\
\mathrm{R} \\
-\end{array}$ & $\begin{array}{l}\mathrm{G} \\
\mathrm{M} \\
\mathrm{M} \\
-\end{array}$ & $\begin{array}{r}47 \\
17 \\
16 \\
-\end{array}$ & \\
\hline
\end{tabular}

\begin{tabular}{|c|c|c|c|c|}
\hline Sample & $\begin{array}{l}\text { Abun- } \\
\text { dance }\end{array}$ & $\begin{array}{l}\text { Preser- } \\
\text { vation }\end{array}$ & $\begin{array}{l}\text { Number of } \\
\text { Individuals }\end{array}$ & $\begin{array}{c}\mathrm{Td} \\
\text { Values }\end{array}$ \\
\hline $\begin{array}{l}174 \mathrm{~A}-1(\mathrm{CC}) \\
174 \mathrm{~A}-2(\mathrm{CC}) \\
174 \mathrm{~A}-3(\mathrm{CC}) \\
174 \mathrm{~A}-4(\mathrm{CC}) \\
174 \mathrm{~A}-5(\mathrm{CC}) \\
174 \mathrm{~A}-6(\mathrm{CC})\end{array}$ & $\begin{array}{l}\bar{R} \\
\bar{R} \\
\mathrm{R} \\
\mathrm{R} \\
\mathrm{R}\end{array}$ & $\begin{array}{l}\bar{M} \\
\bar{M} \\
\mathrm{G} \\
\mathrm{M}\end{array}$ & $\begin{array}{l}- \\
- \\
- \\
12 \\
90 \\
16\end{array}$ & \\
\hline $\begin{array}{l}174 \mathrm{~A}-7(\mathrm{CC}) \\
174 \mathrm{~A}-8(\mathrm{CC}) \\
174 \mathrm{~A}-9(\mathrm{CC}) \\
174 \mathrm{~A}-11(\mathrm{CC}) \\
174 \mathrm{~A}-12(\mathrm{CC}) \\
174 \mathrm{~A}-13(\mathrm{CC}) \\
174 \mathrm{~A}-14(\mathrm{CC}) \\
174 \mathrm{~A}-15(\mathrm{CC}) \\
174 \mathrm{~A}-16(\mathrm{CC}) \\
174 \mathrm{~A}-17(\mathrm{CC})\end{array}$ & $\begin{array}{l}\text { B } \\
\text { B } \\
- \\
\text { R } \\
B \\
B \\
\text { R } \\
\text { R } \\
\text { B } \\
\text { B }\end{array}$ & $\begin{array}{l}- \\
- \\
\bar{M} \\
- \\
\bar{M} \\
\mathrm{G} \\
- \\
-\end{array}$ & $\begin{array}{r}3 \\
3 \\
-\quad \\
22 \\
8 \\
3 \\
8 \\
10 \\
5 \\
3\end{array}$ & \\
\hline $\begin{array}{l}174 \mathrm{~A}-18(\mathrm{CC}) \\
174 \mathrm{~A}-19(\mathrm{CC}) \\
174 \mathrm{~A}-20(\mathrm{CC}) \\
174 \mathrm{~A}-21(\mathrm{CC}) \\
174 \mathrm{~A}-22(\mathrm{CC}) \\
174 \mathrm{~A}-23(\mathrm{CC}) \\
174 \mathrm{~A}-24(\mathrm{CC}) \\
174 \mathrm{~A}-25(\mathrm{CC}) \\
174 \mathrm{~A}-27(\mathrm{CC}) \\
174 \mathrm{~A}-28(\mathrm{CC})\end{array}$ & $\begin{array}{l}\text { B } \\
\text { B } \\
- \\
\text { B } \\
\text { B } \\
\text { R } \\
\text { B } \\
\text { B } \\
\text { B } \\
-\end{array}$ & $\begin{array}{l}- \\
- \\
- \\
- \\
\bar{G} \\
- \\
- \\
- \\
-\end{array}$ & $\begin{array}{r}2 \\
1 \\
-\quad \\
1 \\
2 \\
11 \\
3 \\
4 \\
2 \\
-\end{array}$ & \\
\hline $\begin{array}{l}174 A-29(C C) \\
174 A-31-1(40-41) \\
174 A-31(C C) \\
174 A-32(C C) \\
174 A-33(C C) \\
174 A-34(C C) \\
174 A-35(C C) \\
174 A-36(C C) \\
174 A-37(C C) \\
174 A-38(C C)\end{array}$ & $\begin{array}{l}\mathrm{B} \\
\mathrm{R} \\
\mathrm{R} \\
\mathrm{R} \\
\mathrm{R} \\
\mathrm{B} \\
\mathrm{R} \\
- \\
- \\
-\end{array}$ & $\begin{array}{l}\overline{-} \\
\mathrm{G} \\
\mathrm{G} \\
\mathrm{G} \\
\mathrm{M} \\
\overline{\mathrm{M}} \\
\overline{-} \\
- \\
-\end{array}$ & $\begin{array}{r}4 \\
10 \\
36 \\
39 \\
16 \\
5 \\
51 \\
- \\
- \\
-\end{array}$ & \\
\hline $\begin{array}{l}174 A-39-1(149-150) \\
174 A-39-2(90-91) \\
174 A-39-3(17-19) \\
174 A-39-3(107-109) \\
174 A-39(C C) \\
174 A-40-5(66-67- \\
174 A-40(C C) \\
175-1-1(104-106) \\
175-1-2(79-80) \\
175-1-3(73-74) \\
175-1-4(88-89) \\
175-1(C C) \\
175-1(C C) \\
175-2-2(80-81) \\
175-2-3(83-84) \\
175-2-4(88-89) \\
175-2(C C)\end{array}$ & $\begin{array}{l}- \\
- \\
- \\
- \\
- \\
- \\
\bar{C} \\
\mathrm{C} \\
\mathrm{C} \\
\mathrm{C} \\
\mathrm{C} \\
\mathrm{C} \\
\mathrm{C} \\
\mathrm{C} \\
\mathrm{C} \\
\mathrm{C}\end{array}$ & $\begin{array}{l}- \\
\overline{-} \\
\overline{-} \\
- \\
- \\
\bar{G} \\
\mathrm{G} \\
\mathrm{G} \\
\mathrm{G} \\
\mathrm{G} \\
\mathrm{G} \\
\mathrm{G} \\
\mathrm{G} \\
\mathrm{G} \\
\mathrm{G} \\
\mathrm{G}\end{array}$ & $\begin{array}{l}- \\
- \\
- \\
- \\
- \\
- \\
- \\
648 \\
936 \\
672 \\
876 \\
960 \\
600 \\
756 \\
888 \\
848 \\
600\end{array}$ & $\begin{array}{l}99 \\
97 \\
98 \\
85 \\
86 \\
84 \\
94 \\
80 \\
80 \\
85\end{array}$ \\
\hline $\begin{array}{l}175-3-1(72-73) \\
175-3-2(71-72) \\
175-3-3(90-91) \\
175-3-4(86-87) \\
175-3-4(96-97) \\
175-3-5(72-73) \\
175-3(C C) \\
175-4-2(64-65) \\
175-4-3(72-73) \\
175-4-4(93-94)\end{array}$ & $\begin{array}{l}\mathrm{C} \\
\mathrm{C} \\
\mathrm{C} \\
- \\
- \\
- \\
- \\
\overline{-} \\
\mathrm{C} \\
\mathrm{C}\end{array}$ & $\begin{array}{l}\text { G } \\
G \\
G \\
- \\
- \\
- \\
- \\
\bar{G} \\
G\end{array}$ & $\begin{array}{l}600 \\
936 \\
630 \\
- \\
- \\
- \\
- \\
- \\
624 \\
876\end{array}$ & $\begin{array}{l}95 \\
98 \\
98 \\
- \\
- \\
- \\
- \\
- \\
- \\
-\end{array}$ \\
\hline $\begin{array}{l}175-4-5(64-65) \\
175-4(C C) \\
175-5-1(64-65) \\
175-5-2(88-89) \\
175-5-3(87-88) \\
175-5-4(87-88) \\
175-5-5(50-51) \\
175-5-6(68-69)\end{array}$ & $\begin{array}{l}\mathrm{C} \\
- \\
- \\
- \\
- \\
- \\
- \\
-\end{array}$ & $\begin{array}{l}\text { G } \\
- \\
- \\
- \\
- \\
- \\
- \\
-\end{array}$ & $\begin{array}{l}750 \\
- \\
- \\
- \\
- \\
- \\
- \\
-\end{array}$ & $\begin{array}{l}80 \\
- \\
- \\
- \\
- \\
- \\
-\end{array}$ \\
\hline
\end{tabular}




\begin{tabular}{|c|c|c|c|c|}
\hline Sample & $\begin{array}{l}\text { Abun- } \\
\text { dance }\end{array}$ & $\begin{array}{l}\text { Preser- } \\
\text { vation }\end{array}$ & $\begin{array}{l}\text { Number of } \\
\text { Individuals }\end{array}$ & \begin{tabular}{|c} 
Td \\
Values
\end{tabular} \\
\hline $\begin{array}{l}175-5(\mathrm{CC}) \\
175-6-1(82-83)\end{array}$ & $\begin{array}{l}\mathrm{C} \\
-\end{array}$ & $\begin{array}{l}\text { G } \\
-\end{array}$ & $\begin{array}{l}516 \\
-\end{array}$ & $\begin{array}{l}90 \\
-\end{array}$ \\
\hline $\begin{array}{l}175-6-2(86-87) \\
175-6-3(83-84) \\
175-6-4(81-83) \\
175-6-5(88-89) \\
175-6-6(87-89) \\
175-6(C C) \\
175-7-1(88-89) \\
175-7-2(63-64) \\
175-7-3(87-88) \\
175-7(C C)\end{array}$ & $\begin{array}{l}- \\
\overline{-} \\
\mathrm{C} \\
\mathrm{C} \\
\mathrm{C} \\
\overline{-} \\
\mathrm{C} \\
\mathrm{C} \\
\mathrm{C} \\
\mathrm{R}\end{array}$ & $\begin{array}{l}- \\
\bar{G} \\
\mathrm{G} \\
\mathrm{G} \\
\overline{-} \\
\mathrm{G} \\
\mathrm{G} \\
\mathrm{G} \\
\mathrm{M}\end{array}$ & $\begin{array}{l}- \\
\overline{612} \\
660 \\
576 \\
\overline{816} \\
660 \\
612 \\
233\end{array}$ & $\begin{array}{l}- \\
\overline{9} \\
87 \\
85 \\
- \\
85 \\
70 \\
80 \\
-\end{array}$ \\
\hline $\begin{array}{l}175-8-2(86-87) \\
175-8(C C) \\
175-9-2(79-80) \\
175-9-3(88-89) \\
175-9-4(78-79) \\
175-9(C C) \\
175-10-2(78-79) \\
175-10-3(78-79) \\
175-10-4(78-79) \\
175-10-5(79-80)\end{array}$ & $\begin{array}{l}\mathrm{C} \\
\mathrm{C} \\
\mathrm{C} \\
\mathrm{C} \\
\mathrm{C} \\
\mathrm{C} \\
\mathrm{C} \\
\mathrm{C} \\
\mathrm{C} \\
\mathrm{C}\end{array}$ & $\begin{array}{l}\text { G } \\
M \\
G \\
G \\
G \\
G \\
G \\
G \\
G \\
G\end{array}$ & $\begin{array}{r}480 \\
450 \\
510 \\
1344 \\
900 \\
1428 \\
1010 \\
828 \\
684 \\
936\end{array}$ & $\begin{array}{l}- \\
\overline{-} \\
84 \\
60 \\
51 \\
78 \\
\overline{90} \\
84 \\
86\end{array}$ \\
\hline $\begin{array}{l}175-10(\mathrm{CC}) \\
175-11-2(79-80) \\
175-11-3(79-80) \\
175-11-4(80-81 \\
175-11-5(65-66) \\
175-11(\mathrm{CC}) \\
175-12-1(87-88) \\
175-12(\mathrm{CC}) \\
175-13-2(67-68) \\
175-13-3(65-66)\end{array}$ & $\begin{array}{l}\mathrm{C} \\
\mathrm{C} \\
\mathrm{C} \\
\mathrm{C} \\
\mathrm{R} \\
\mathrm{C} \\
\mathrm{C} \\
\mathrm{C} \\
\mathrm{C} \\
\mathrm{C}\end{array}$ & $\begin{array}{l}M \\
G \\
G \\
G \\
M \\
G \\
G \\
G \\
G \\
G\end{array}$ & $\begin{array}{r}624 \\
336 \\
351 \\
340 \\
300 \\
888 \\
752 \\
1008 \\
910 \\
980\end{array}$ & $\begin{array}{l}- \\
60 \\
64 \\
64 \\
- \\
50 \\
- \\
64 \\
- \\
-\end{array}$ \\
\hline $\begin{array}{l}175-13-4(65-66) \\
175-13(C C) \\
175-14-2(65-66) \\
175-14-3(65-66) \\
175-14-4(65-66) \\
175-14-5(93-94) \\
175-14-6(65-66) \\
175-14(C C) \\
175-15-2(65-66) \\
175-15-3(65-66)\end{array}$ & $\begin{array}{l}\text { C } \\
\text { C } \\
\text { C } \\
- \\
- \\
- \\
\overline{-} \\
\text { B } \\
\overline{\text { G }}\end{array}$ & $\begin{array}{l}\text { G } \\
G \\
G \\
- \\
\overline{-} \\
- \\
- \\
\bar{G}\end{array}$ & $\begin{array}{l}720 \\
528 \\
410 \\
- \\
- \\
- \\
- \\
- \\
- \\
-\end{array}$ & $\begin{array}{l}- \\
- \\
- \\
- \\
- \\
- \\
- \\
- \\
\overline{75}\end{array}$ \\
\hline $\begin{array}{l}175-15-4(63-64) \\
175-15-5(65-66) \\
175-15(C C) \\
175-16-1(65-66) \\
175-16-2(65-66) \\
175-16-3(65-66) \\
175-16-4(65-66) \\
175-16-6(68-69) \\
175-16(C C) \\
175-17-2(68-69)\end{array}$ & $\begin{array}{l}\mathrm{C} \\
\mathrm{C} \\
\mathrm{C} \\
- \\
- \\
- \\
- \\
- \\
\mathrm{C} \\
\mathrm{C}\end{array}$ & $\begin{array}{l}\text { C } \\
\text { G } \\
\text { G } \\
- \\
- \\
- \\
- \\
\bar{G} \\
\text { G }\end{array}$ & $\begin{array}{l}\overline{4} \\
480 \\
- \\
\overline{-} \\
\overline{-} \\
\overline{780} \\
800\end{array}$ & $\begin{array}{c}64 \\
90 \\
- \\
- \\
- \\
- \\
- \\
\overline{43} \\
39\end{array}$ \\
\hline $\begin{array}{l}175-17-3(93-94) \\
175-17-4(65-66) \\
175-17-5(65-67) \\
175-17-6(65-66) \\
175-17(\mathrm{CC}) \\
175-18-1(65-66) \\
175-18-2(65-66) \\
175-18-3(65-66) \\
175-18-4(65-66) \\
175-18(\mathrm{CC})\end{array}$ & $\begin{array}{l}\mathrm{C} \\
\mathrm{C} \\
- \\
\mathrm{C} \\
\mathrm{C} \\
\mathrm{C} \\
\mathrm{C} \\
\mathrm{C} \\
\mathrm{C} \\
\mathrm{C}\end{array}$ & $\begin{array}{l}\text { G } \\
G \\
G \\
G \\
G \\
G \\
G \\
G \\
G \\
G\end{array}$ & $\begin{array}{l}504 \\
720 \\
- \\
696 \\
768 \\
750 \\
650 \\
570 \\
576 \\
888\end{array}$ & $\begin{array}{l}25 \\
36 \\
- \\
50 \\
- \\
56 \\
65 \\
36 \\
60 \\
-\end{array}$ \\
\hline $\begin{array}{l}175-19-2(65-66) \\
175-19(C C) \\
175-20-2(65-66) \\
175-20-3(65-66) \\
175-20(C C) \\
175-21-1(65-66) \\
175-21-2(30) \\
175-21-2(65-66)\end{array}$ & $\begin{array}{l}\text { R } \\
\text { B } \\
\text { C } \\
\text { C } \\
\text { C } \\
\text { C } \\
\text { B } \\
\text { R }\end{array}$ & $\begin{array}{l}M \\
\bar{G} \\
G \\
G \\
G \\
\bar{P}\end{array}$ & $\begin{array}{r}28 \\
6 \\
- \\
492 \\
816 \\
936 \\
- \\
1\end{array}$ & $\begin{array}{l}- \\
\overline{52} \\
\overline{28} \\
36 \\
- \\
-\end{array}$ \\
\hline
\end{tabular}

\begin{tabular}{|c|c|c|c|c|}
\hline Sample & $\begin{array}{l}\text { Abun- } \\
\text { dance }\end{array}$ & $\begin{array}{l}\text { Preser- } \\
\text { vation }\end{array}$ & $\begin{array}{l}\text { Number of } \\
\text { Individuals }\end{array}$ & $\begin{array}{c}\text { Td } \\
\text { Values }\end{array}$ \\
\hline $\begin{array}{l}175-21(\mathrm{CC}) \\
175-22(\mathrm{CC})\end{array}$ & $\begin{array}{l}\text { B } \\
\text { B }\end{array}$ & - & $\begin{array}{l}1 \\
3\end{array}$ & $\begin{array}{l}- \\
-\end{array}$ \\
\hline $\begin{array}{l}176-1-1(65-66) \\
176-1-2(66-67) \\
176-1-3(60-61) \\
176-1-4(21-22) \\
176-1(C C) \\
176-2-1(24-25) \\
176-2-2(67-68) \\
176-2-3(65-66) \\
176-2-4(65-66) \\
176-2-5(65-66)\end{array}$ & $\begin{array}{l}\text { A } \\
\text { C } \\
\text { B } \\
\text { B } \\
\text { C } \\
\text { B } \\
\text { B } \\
\text { B } \\
\text { C } \\
\text { C }\end{array}$ & $\begin{array}{l}\mathrm{G} \\
\mathrm{G} \\
\overline{-} \\
\overline{\mathrm{M}} \\
\overline{-} \\
\overline{-} \\
\overline{\mathrm{M}} \\
\mathrm{M}\end{array}$ & $\begin{array}{r}2016 \\
833 \\
0 \\
0 \\
361 \\
0 \\
0 \\
0 \\
407 \\
367\end{array}$ & \\
\hline $\begin{array}{l}176-2-6(65-66) \\
176-2(\mathrm{CC}) \\
176-3-1(65-66) \\
176-3-2(65-66) \\
176-3-3(65-66) \\
176-3-4(65-66) \\
176-3-5(65-66) \\
176-3-6(9-10) \\
176-3(\mathrm{CC}) \\
176-3 \text { (CC) [rock] }\end{array}$ & $\begin{array}{l}C \\
R \\
R \\
R \\
R \\
R \\
R \\
R \\
R \\
B\end{array}$ & $\begin{array}{l}\mathrm{M} \\
\mathrm{M} \\
\mathrm{M} \\
\mathrm{M} \\
\mathrm{M} \\
\mathrm{M} \\
\mathrm{M} \\
\mathrm{M} \\
\mathrm{M} \\
-\end{array}$ & $\begin{array}{r}200 \\
129 \\
109 \\
71 \\
96 \\
76 \\
79 \\
74 \\
140 \\
0\end{array}$ & \\
\hline $\begin{array}{l}176-4-2(68-69) \\
176-4-3(56-57) \\
176-4-4(56-57) \\
176-4-5(68-69) \\
176-4-6(65-66) \\
176-4(C C) \\
176-5-1(71-72) \\
176-5-2(65-66) \\
176-5-3(63-64) \\
176-5-4(63-64)\end{array}$ & $\begin{array}{l}\mathrm{R} \\
\mathrm{R} \\
\mathrm{R} \\
\mathrm{R} \\
\mathrm{R} \\
\mathrm{R} \\
\mathrm{R} \\
\mathrm{R} \\
\mathrm{R} \\
\mathrm{R}\end{array}$ & $\begin{array}{l}\mathrm{P} \\
\mathrm{M} \\
\mathrm{M} \\
\mathrm{M} \\
\mathrm{M} \\
\mathrm{P} \\
\mathrm{M} \\
\mathrm{P} \\
\mathrm{M} \\
\mathrm{P}\end{array}$ & $\begin{array}{r}67 \\
48 \\
64 \\
59 \\
101 \\
14 \\
44 \\
84 \\
95 \\
48\end{array}$ & \\
\hline $\begin{array}{l}176-5-5(68-69) \\
176-5-6(66-67) \\
176-5(C C)\end{array}$ & $\begin{array}{l}\mathrm{R} \\
\mathrm{R} \\
\mathrm{R}\end{array}$ & $\begin{array}{l}\mathrm{P} \\
\mathrm{P} \\
\mathrm{P}\end{array}$ & $\begin{array}{l}82 \\
19 \\
52\end{array}$ & \\
\hline $\begin{array}{l}177-1-1(47-48) \\
177-1-2(65-66) \\
177-1-3(64-65) \\
177-1-4(43-44) \\
177-1-5(66-67) \\
177-1-6(65-66) \\
177-1(C C) \\
177 \mathrm{~A}-1-1(65-66) \\
177 \mathrm{~A}-1-2(67-68) \\
177 \mathrm{~A}-1(\mathrm{CC})\end{array}$ & $\begin{array}{l}\mathrm{R} \\
\mathrm{R} \\
\mathrm{R} \\
\mathrm{R} \\
\mathrm{R} \\
\mathrm{R} \\
\mathrm{R} \\
\mathrm{R} \\
\mathrm{R} \\
\mathrm{R}\end{array}$ & $\begin{array}{l}P \\
P \\
M \\
M \\
M \\
M \\
M \\
G \\
G \\
M \\
M \\
G\end{array}$ & $\begin{array}{r}16 \\
36 \\
14 \\
14 \\
15 \\
18 \\
40 \\
102 \\
33 \\
21\end{array}$ & $\begin{array}{l}- \\
- \\
- \\
- \\
- \\
\overline{98} \\
82 \\
- \\
-\end{array}$ \\
\hline $\begin{array}{l}177 \mathrm{~A}-2-6(107-108) \\
177 \mathrm{~A}-2(C \mathrm{C}) \\
177 \mathrm{~A}-3-1(95-96) \\
177 \mathrm{~A}-3-2(55-56) \\
177 \mathrm{~A}-3-3(65-67) \\
177 \mathrm{~A}-3-4(63-65) \\
177 \mathrm{~A}-3-5(60-62) \\
177 \mathrm{~A}-3-6(64-66) \\
177 \mathrm{~A}-3(\mathrm{CC}) \\
177 \mathrm{~A}-4-1(129-131)\end{array}$ & $\begin{array}{l}\mathrm{F} \\
\mathrm{R} \\
\mathrm{R} \\
\mathrm{R} \\
\mathrm{R} \\
\mathrm{R} \\
\mathrm{R} \\
\mathrm{R} \\
\mathrm{R} \\
\mathrm{R}\end{array}$ & $\begin{array}{l}\mathrm{M} \\
\mathrm{M} \\
\mathrm{M} \\
\mathrm{P} \\
\mathrm{P} \\
\mathrm{M} \\
\mathrm{P} \\
\mathrm{P} \\
\mathrm{M} \\
\mathrm{P}\end{array}$ & $\begin{array}{r}78 \\
16 \\
27 \\
21 \\
16 \\
23 \\
13 \\
15 \\
10 \\
7\end{array}$ & $\begin{array}{l}84 \\
- \\
- \\
- \\
- \\
- \\
- \\
- \\
- \\
-\end{array}$ \\
\hline $\begin{array}{l}177 A-4-2(66-68) \\
177 A-4-3(65-67) \\
177 A-4-4(64-66) \\
177 A-4-5(64-66) \\
177 A-4(C C) \\
177 A-5-1(68-70) \\
177 A-5-2(64-66) \\
177 A-5-3(65-67) \\
177 A-5-4(64-66) \\
177 A-5-5(87-89)\end{array}$ & $\begin{array}{l}\mathrm{R} \\
\mathrm{C} \\
\mathrm{R} \\
\mathrm{C} \\
\mathrm{R} \\
\mathrm{R} \\
\mathrm{C} \\
\mathrm{R} \\
\mathrm{R} \\
\mathrm{R}\end{array}$ & $\begin{array}{l}M \\
G \\
M \\
G \\
G \\
M \\
G \\
P \\
M \\
M\end{array}$ & $\begin{array}{r}22 \\
154 \\
11 \\
175 \\
56 \\
26 \\
147 \\
4 \\
23 \\
23 \\
57\end{array}$ & $\begin{array}{l}\overline{92} \\
\overline{52} \\
\overline{-} \\
\overline{30} \\
- \\
- \\
-\end{array}$ \\
\hline $\begin{array}{l}177 A-5-6(69-71) \\
177 A-5(C C) \\
177 A-6-1(70-72) \\
177 A-6-2(64-66) \\
\end{array}$ & $\begin{array}{l}\mathrm{R} \\
\mathrm{C} \\
\mathrm{R} \\
\mathrm{R} \\
\end{array}$ & $\begin{array}{l}\mathrm{M} \\
\mathrm{M} \\
\mathrm{M} \\
\mathrm{M}\end{array}$ & $\begin{array}{r}109 \\
636 \\
59 \\
40 \\
\end{array}$ & $\begin{array}{l}- \\
5 \\
- \\
-\end{array}$ \\
\hline
\end{tabular}




\begin{tabular}{|c|c|c|c|c|}
\hline Sample & $\begin{array}{l}\text { Abun- } \\
\text { dance }\end{array}$ & $\begin{array}{l}\text { Preser- } \\
\text { vation }\end{array}$ & $\begin{array}{l}\text { Number of } \\
\text { Individuals }\end{array}$ & $\begin{array}{c}\text { Td } \\
\text { Values }\end{array}$ \\
\hline $\begin{array}{l}177 \text { A-6-3 }(64-66) \\
177 \text { A-6-4 (67-69) } \\
177 \text { A-6-5 (64-66) } \\
177 \text { A-6(CC) } \\
177 A-7-1(63-65) \\
177 A-7-2(65-67)\end{array}$ & $\begin{array}{l}\mathrm{R} \\
\mathrm{C} \\
\mathrm{C} \\
\mathrm{C} \\
\mathrm{C} \\
\mathrm{C}\end{array}$ & $\begin{array}{l}M \\
M \\
G \\
G \\
G \\
M\end{array}$ & $\begin{array}{r}73 \\
200 \\
720 \\
540 \\
528 \\
199\end{array}$ & $\begin{array}{l}- \\
\overline{46} \\
53 \\
42 \\
-\end{array}$ \\
\hline $\begin{array}{l}177 \mathrm{~A}-7(\mathrm{CC}) \\
177 \mathrm{~A}-8-1(65-67) \\
177 \mathrm{~A}-8-2(65-67) \\
177 \mathrm{~A}-8-4(79-81) \\
177 \mathrm{~A}-8-4(94-96) \\
177 \mathrm{~A}-8-5(57-59) \\
177 \mathrm{~A}-8-6(69-71) \\
177 \mathrm{~A}-8(\mathrm{CC}) \\
177 \mathrm{~A}-9-4(53-55) \\
177 \mathrm{~A}-9-5(65-67)\end{array}$ & $\begin{array}{l}\text { R } \\
A \\
A \\
\text { C } \\
A \\
\text { R } \\
\text { R } \\
\text { R } \\
\text { R } \\
\text { R }\end{array}$ & $\begin{array}{l}M \\
G \\
G \\
G \\
M \\
M \\
M \\
M \\
M \\
G \\
M\end{array}$ & $\begin{array}{r}57 \\
1836 \\
1956 \\
708 \\
1128 \\
26 \\
43 \\
27 \\
41 \\
23\end{array}$ & $\begin{array}{r}- \\
10 \\
5 \\
34 \\
34 \\
- \\
- \\
34 \\
- \\
-\end{array}$ \\
\hline $\begin{array}{l}\text { 177A-9-6 (44-46) } \\
\text { 177A-9(CC) } \\
\text { 177A-10-4 (88-90) } \\
\text { 177A-10(CC) [coarser?] } \\
\text { 177A-10(CC) [finer] } \\
\text { 177A-11-1 (127-129) } \\
177 \mathrm{~A}-11-1(148-150) \\
177 \mathrm{~A}-11-2(65-67) \\
177 \mathrm{~A}-11-2(76-78) \\
177 \mathrm{~A}-11-2(139-141)\end{array}$ & $\begin{array}{l}\text { R } \\
\text { B } \\
\text { B } \\
\text { B } \\
\text { B } \\
\text { R } \\
\text { B } \\
\text { C } \\
\text { C } \\
\text { C }\end{array}$ & $\begin{array}{l}\mathrm{P} \\
- \\
- \\
- \\
\overline{\mathrm{M}} \\
\overline{\mathrm{M}} \\
\mathrm{M} \\
\mathrm{M}\end{array}$ & $\begin{array}{r}10 \\
1 \\
0 \\
0 \\
0 \\
242 \\
0 \\
160 \\
122 \\
612\end{array}$ & $\begin{array}{l}- \\
- \\
- \\
- \\
- \\
30 \\
\overline{10} \\
10 \\
5\end{array}$ \\
\hline $\begin{array}{l}177 \mathrm{~A}-11-3(39-40) \\
177 \mathrm{~A}-11-3(65-67) \\
177 \mathrm{~A}-11-4(32-34) \\
177 \mathrm{~A}-11-4(63-65) \\
177 \mathrm{~A}-11-4(90-91) \\
177 \mathrm{~A}-11-4(141-143) \\
177 \mathrm{~A}-11(\mathrm{CC}) \\
177 \mathrm{~A}-12-1(118-120) \\
177 \mathrm{~A}-12-2(63-65) \\
177 \mathrm{~A}-12-3(63-65)\end{array}$ & $\begin{array}{l}\mathrm{R} \\
\mathrm{R} \\
\mathrm{C} \\
\mathrm{B} \\
\mathrm{C} \\
\mathrm{R} \\
\mathrm{R} \\
\mathrm{R} \\
\mathrm{B} \\
\mathrm{B}\end{array}$ & $\begin{array}{l}\mathrm{M} \\
\mathrm{P} \\
\mathrm{G} \\
- \\
\mathrm{M} \\
\mathrm{M} \\
\mathrm{M} \\
\mathrm{M} \\
- \\
-\end{array}$ & $\begin{array}{r}158 \\
33 \\
1176 \\
0 \\
732 \\
280 \\
52 \\
50 \\
0 \\
0\end{array}$ & $\begin{array}{l}\overline{20} \\
22 \\
\overline{22} \\
\overline{10} \\
- \\
- \\
-\end{array}$ \\
\hline $\begin{array}{l}177 \mathrm{~A}-12(\mathrm{CC}) \\
177 \mathrm{~A}-12(\mathrm{CC}) \\
177 \mathrm{~A}-13(\mathrm{CC}) \\
177 \mathrm{~A}-14-2(57-59) \\
177 \mathrm{~A}-14-3(89-91) \\
177 \mathrm{~A}-14-4(63-65) \\
177 \mathrm{~A}-14-5(63-65) \\
177 \mathrm{~A}-14-6(66-68) \\
177 \mathrm{~A}-14(\mathrm{CC}) \\
177 \mathrm{~A}-15-1(106-108)\end{array}$ & $\begin{array}{l}\text { B } \\
\text { B } \\
\text { B } \\
\text { B } \\
\text { B } \\
\text { B } \\
\text { B } \\
\text { B } \\
\text { B } \\
\text { B }\end{array}$ & $\begin{array}{l}\bar{z} \\
\overline{-} \\
\bar{z} \\
\overline{-} \\
\overline{-} \\
-\end{array}$ & $\begin{array}{l}0 \\
0 \\
0 \\
0 \\
0 \\
0 \\
0 \\
0 \\
0 \\
0\end{array}$ & $\begin{array}{l}- \\
- \\
- \\
- \\
- \\
-\end{array}$ \\
\hline $\begin{array}{l}177 A-15-2(63-65) \\
177 A-15-3(126-128) \\
177 A-15-4(55-57) \\
177 A-15-5(62-64) \\
177 A-15(C C) \\
177 A-16-1(131-133) \\
177 A-16-2(74-76) \\
177 A-16(C C) \\
177 A-17-2(63-65) \\
177 A-17-3(62-64)\end{array}$ & $\begin{array}{l}\text { B } \\
\text { B } \\
\text { B } \\
\text { B } \\
\text { B } \\
\text { B } \\
\text { B } \\
\text { B } \\
\text { B } \\
\text { B }\end{array}$ & $\begin{array}{l}- \\
- \\
- \\
- \\
- \\
- \\
-\end{array}$ & $\begin{array}{l}0 \\
0 \\
0 \\
0 \\
0 \\
0 \\
0 \\
0 \\
0 \\
0\end{array}$ & $\begin{array}{l}- \\
- \\
- \\
- \\
- \\
- \\
- \\
-\end{array}$ \\
\hline $\begin{array}{l}177 A-17-4(65-67) \\
177 A-17(C C) \\
177 A-18-1(62-64) \\
177 A-18-2(58-60) \\
177 A-18-3(58-60) \\
177 A-18(C C) \\
177 A-19-1(131-133) \\
177 A-19-2(67-69) \\
177 A-19-3(66-67) \\
177 A-19(C C)\end{array}$ & $\begin{array}{l}\text { B } \\
\text { B } \\
\text { B } \\
\text { B } \\
\text { B } \\
\text { B } \\
\text { B } \\
\text { B } \\
\text { B } \\
\text { B }\end{array}$ & $\begin{array}{l}\bar{z} \\
\overline{-} \\
- \\
\overline{-} \\
\overline{-} \\
\overline{-} \\
\overline{-}\end{array}$ & $\begin{array}{l}0 \\
0 \\
0 \\
0 \\
0 \\
0 \\
0 \\
0 \\
0 \\
0\end{array}$ & $\begin{array}{l}- \\
- \\
- \\
- \\
- \\
- \\
- \\
- \\
-\end{array}$ \\
\hline $\begin{array}{l}177 \mathrm{~A}-20-1(125-126) \\
177 \mathrm{~A}-20-2(89-91) \\
177 \mathrm{~A}-20-3(80-81) \\
177 \mathrm{~A}-20(\mathrm{CC}) \\
177 \mathrm{~A}-21-2(62-63)\end{array}$ & $\begin{array}{l}\text { B } \\
\text { B } \\
\text { B } \\
\text { B } \\
\text { B }\end{array}$ & $\begin{array}{l}- \\
- \\
- \\
-\end{array}$ & $\begin{array}{l}0 \\
0 \\
0 \\
0 \\
0\end{array}$ & $\begin{array}{l}- \\
- \\
- \\
-\end{array}$ \\
\hline
\end{tabular}

\begin{tabular}{|c|c|c|c|c|}
\hline Sample & $\begin{array}{l}\text { Abun- } \\
\text { dance }\end{array}$ & $\begin{array}{l}\text { Preser- } \\
\text { vation }\end{array}$ & $\begin{array}{l}\text { Number of } \\
\text { Individuals }\end{array}$ & $\begin{array}{c}\text { Td } \\
\text { Values }\end{array}$ \\
\hline 177 A-21-3 (73-74) & B & - & 0 & - \\
\hline $177 \mathrm{~A}-21(\mathrm{CC})$ & B & - & 0 & - \\
\hline $177 \mathrm{~A}-22-2(72-73)$ & B & - & 0 & - \\
\hline 177 A- $22-3(37-38)$ & B & - & 0 & - \\
\hline $177 \mathrm{~A}-22-4(77-78)$ & B & - & 0 & - \\
\hline $177 \mathrm{~A}-22(\mathrm{CC})$ & B & - & 0 & - \\
\hline 177 A-23-1 (84-85) & B & - & 0 & - \\
\hline 177 A-23-2 (92-93) & B & - & 0 & - \\
\hline $177 \mathrm{~A}-23-3(97-98)$ & B & - & 0 & - \\
\hline 177 A- $23-4(51-52)$ & B & - & 0 & - \\
\hline $177 \mathrm{~A}-23-5(39-40)$ & B & - & 0 & - \\
\hline $177 \mathrm{~A}-23(\mathrm{CC})$ & B & - & 0 & - \\
\hline 177 A- $25-3(46-47)$ & B & - & 0 & - \\
\hline $177 \mathrm{~A}-25-4(25-26)$ & B & - & 0 & - \\
\hline $177 \mathrm{~A}-25(\mathrm{CC})$ & B & - & 0 & - \\
\hline $177 \mathrm{~A}-26-1(64-65)$ & B & - & 0 & - \\
\hline 177 A-26-1 (91-92) & B & - & 0 & - \\
\hline $178-1-1(45-47)$ & $\mathrm{C}$ & G & 214 & - \\
\hline $178-1-1(120-121)$ & B & - & 4 & - \\
\hline $178-1-2(44-46)$ & $\mathrm{R}$ & M & 31 & - \\
\hline $178-1-2(119-121)$ & $\mathrm{R}$ & M & 46 & - \\
\hline $178-1-3(45-47)$ & $\mathrm{R}$ & $\mathbf{P}$ & 19 & - \\
\hline $178-1-3(120)$ & $\mathrm{R}$ & M & 12 & - \\
\hline $178-1-4(45-47)$ & $\mathbf{R}$ & M & 12 & - \\
\hline $178-1-4(120-122)$ & $\mathrm{C}$ & G & 984 & - \\
\hline $178-1(\mathrm{CC})$ & $\mathrm{R}$ & M & 14 & \\
\hline $178-2-1(55-57)$ & A & G & 3800 & 10 \\
\hline $178-2-1(120)$ & A & G & 4044 & - \\
\hline $178-2-1(120-122)$ & A & G & 3000 & 11 \\
\hline $178-2-2(45-47)$ & $\mathrm{R}$ & M & 46 & - \\
\hline $178-2-2(120-122)$ & $\mathrm{R}$ & $\mathbf{P}$ & 18 & - \\
\hline $178-2-3(45-47)$ & $\mathrm{R}$ & G & 49 & - \\
\hline $178-2-3(120-122)$ & $\mathbf{R}$ & $\mathrm{P}$ & 11 & - \\
\hline $178-2(\mathrm{CC})$ & $\mathrm{C}$ & G & 1224 & - \\
\hline $178-3-1(90-92)$ & $\mathrm{C}$ & M & 360 & - \\
\hline $178-3-2(44-46)$ & $\mathrm{R}$ & $\mathrm{P}$ & 22 & - \\
\hline $178-3-2(119-121)$ & $\mathrm{C}$ & G & 684 & - \\
\hline $178-3-3(45-47)$ & $\mathrm{C}$ & M & 480 & - \\
\hline $178-3-3(120-122)$ & C & G & 1536 & - \\
\hline $178-3-4(40-42)$ & $\mathrm{R}$ & $\mathbf{P}$ & 11 & - \\
\hline $178-3-4(118-120)$ & $\mathrm{R}$ & $\mathbf{P}$ & 19 & - \\
\hline $178-3(\mathrm{CC})$ & $\mathrm{R}$ & M & 103 & - \\
\hline $178-4-1(44-46)$ & $\mathrm{R}$ & $\mathbf{P}$ & 5 & - \\
\hline $178-4-1(119-121)$ & $\mathrm{R}$ & M & 14 & - \\
\hline $178-4-2(45-47)$ & B & - & 6 & - \\
\hline $178-4-2(120-122)$ & $\mathrm{R}$ & M & 20 & - \\
\hline $178-4-3(45-47)$ & $\mathrm{R}$ & M & 73 & - \\
\hline $178-4-3(120-122)$ & $\mathrm{C}$ & G & 708 & - \\
\hline $178-4-4(51-53)$ & B & - & 8 & - \\
\hline $178-4-4(120-122)$ & $\mathrm{R}$ & M & 23 & - \\
\hline $178-4(\mathrm{CC})$ & $\mathrm{C}$ & M & 444 & - \\
\hline $178-5-1(80-82)$ & $\mathbf{R}$ & $\mathbf{P}$ & 5 & - \\
\hline $178-5-1(140-142)$ & $\mathrm{R}$ & $\mathbf{P}$ & 5 & - \\
\hline $178-5-2(45-47)$ & $\mathrm{R}$ & P & 5 & - \\
\hline $178-5-2(120-122)$ & $\mathrm{R}$ & $\mathbf{P}$ & 10 & - \\
\hline $178-5-3(45-47)$ & $\mathrm{R}$ & M & 5 & - \\
\hline $178-5-3(120-122)$ & $\mathrm{C}$ & G & 504 & - \\
\hline $178-5-4(45-47)$ & $\mathbf{R}$ & M & 8 & - \\
\hline $178-5-4(120-122)$ & $\mathrm{C}$ & G & 1680 & - \\
\hline $178-5(\mathrm{CC})$ & A & G & 1536 & - \\
\hline $178-6-2(46-48)$ & $\mathrm{R}$ & $P$ & 3 & - \\
\hline $178-6-2(130-132)$ & $\mathbf{R}$ & $\mathbf{P}$ & 15 & - \\
\hline $178-6-3(45-47)$ & $\mathbf{R}$ & M & 32 & - \\
\hline $178-6-3(130-132)$ & A & G & 1200 & 12 \\
\hline $178-6-4(45-47)$ & $\mathbf{R}$ & M & 17 & - \\
\hline $178-6-4(120-122)$ & $\mathrm{C}$ & G & 1460 & - \\
\hline $178-6(\mathrm{CC})$ & $\mathrm{R}$ & M & 47 & - \\
\hline $178-7(\mathrm{CC})$ & R & G & 197 & - \\
\hline $178-8-1(57-59)$ & $\mathbf{R}$ & G & 102 & - \\
\hline
\end{tabular}




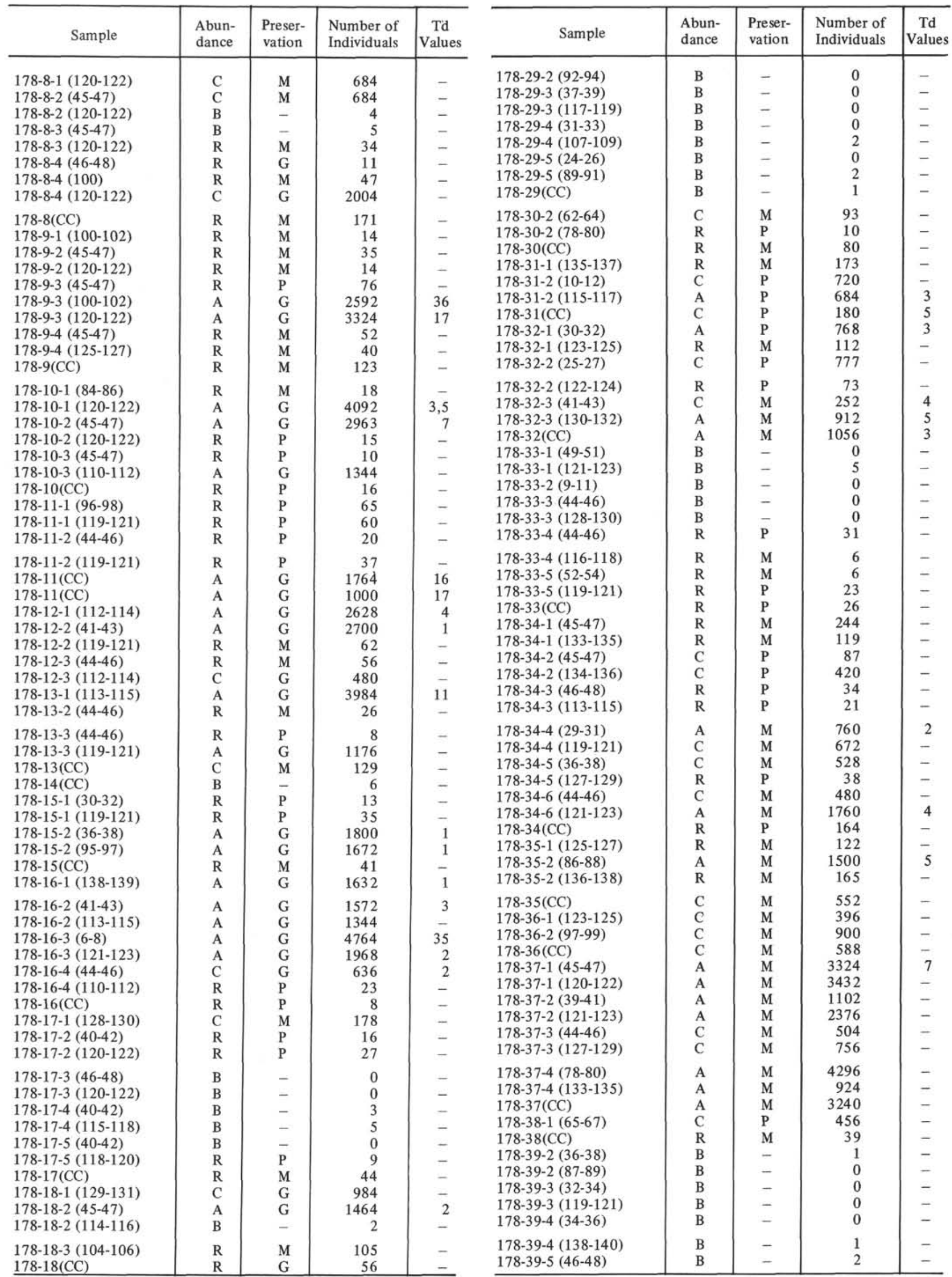


CENOZOIC DIATOMS, NORTHEAST PACIFIC

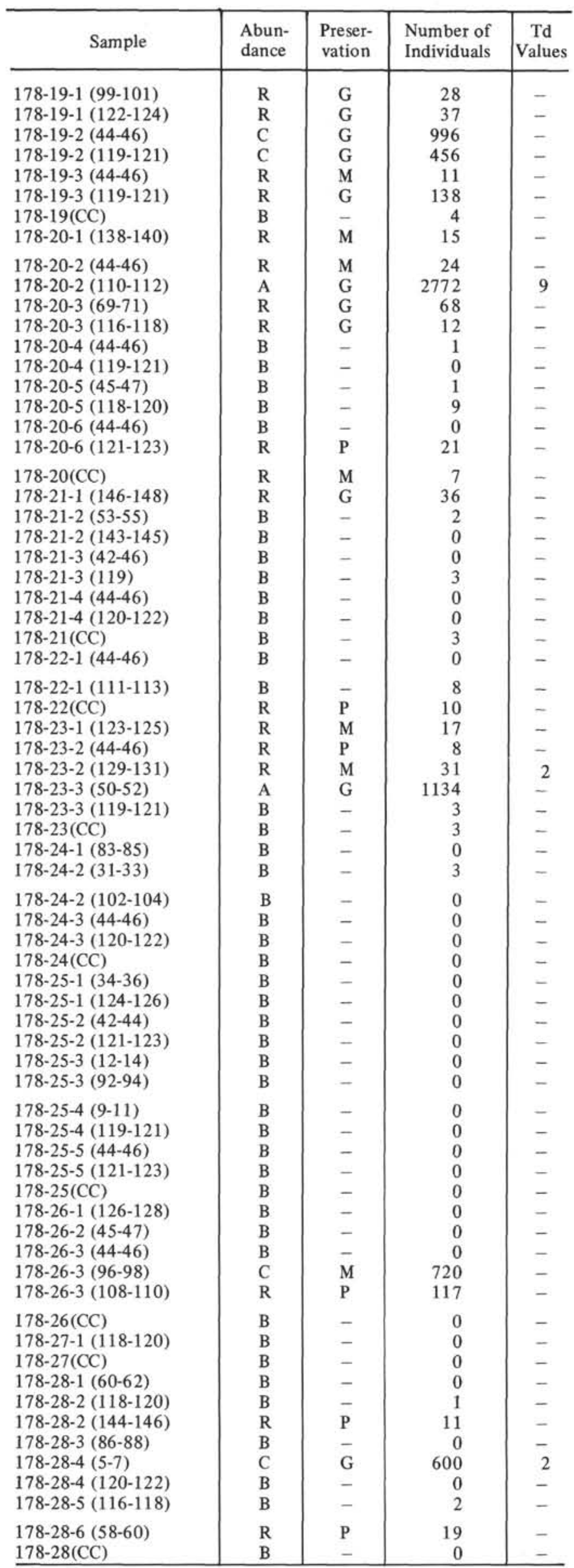

\begin{tabular}{|c|c|c|c|c|}
\hline Sample & $\begin{array}{l}\text { Abun- } \\
\text { dance }\end{array}$ & $\begin{array}{l}\text { Preser- } \\
\text { vation }\end{array}$ & $\begin{array}{l}\text { Number of } \\
\text { Individuals }\end{array}$ & $\begin{array}{c}\text { Td } \\
\text { Values }\end{array}$ \\
\hline $\begin{array}{l}178-39-5(122-124) \\
178-39-6(70-72) \\
178-39-6(129-131) \\
178-39(C C) \\
178-40(C C) \\
178-42(C C) \\
178-43-1(16-18) \\
178-43-1(116-118)\end{array}$ & $\begin{array}{l}\text { A } \\
\text { C } \\
\text { A } \\
\text { C } \\
\text { A } \\
\text { B } \\
\text { B } \\
\text { R }\end{array}$ & $\begin{array}{l}P \\
P \\
P \\
P \\
P \\
- \\
\bar{P}\end{array}$ & $\begin{array}{r}3672 \\
684 \\
4140 \\
660 \\
1968 \\
0 \\
0 \\
76\end{array}$ & $\begin{array}{l}- \\
- \\
- \\
- \\
- \\
-\end{array}$ \\
\hline $\begin{array}{l}178-43-3(42-44) \\
178-43-3(131-133) \\
178-43(C C) \\
178-44-1(72-74) \\
178-44-1(140-142) \\
178-44-2(16-18) \\
178-44-2(71-73) \\
178-44-3(58-60) \\
178-44-4(116-118) \\
178-44-5(25-27)\end{array}$ & $\begin{array}{l}\mathrm{R} \\
\mathrm{A} \\
\mathrm{R} \\
\mathrm{C} \\
\mathrm{R} \\
\mathrm{A} \\
\mathrm{A} \\
\mathrm{A} \\
\mathrm{B} \\
\mathrm{R}\end{array}$ & $\begin{array}{l}\mathrm{P} \\
\mathrm{P} \\
\mathrm{P} \\
\mathrm{P} \\
\mathrm{P} \\
\mathrm{P} \\
\mathrm{P} \\
\mathrm{P} \\
\bar{P}\end{array}$ & $\begin{array}{r}97 \\
3660 \\
10 \\
312 \\
78 \\
3900 \\
3804 \\
4260 \\
6 \\
81\end{array}$ & $\begin{array}{l}- \\
- \\
- \\
- \\
- \\
- \\
- \\
-\end{array}$ \\
\hline $\begin{array}{l}178-44-5(81-83) \\
178-44-6(53-55) \\
178-44-6(121-123) \\
178-44(C C) \\
178-45-1(32-34) \\
178-45-1(119-121) \\
178-45(C C) \\
178-46-1(90-92) \\
178-46-2(32-34) \\
178-46(C C)\end{array}$ & $\begin{array}{l}\text { A } \\
\text { A } \\
\text { A } \\
\text { A } \\
\text { A } \\
\text { R } \\
\text { B } \\
\text { B } \\
\text { C } \\
\text { B }\end{array}$ & $\begin{array}{l}\mathrm{M} \\
\mathrm{M} \\
\mathrm{M} \\
\mathrm{M} \\
\mathrm{M} \\
\mathrm{P} \\
- \\
- \\
\mathrm{P} \\
-\end{array}$ & $\begin{array}{r}2112 \\
1512 \\
1704 \\
1788 \\
1176 \\
28 \\
3 \\
3 \\
648 \\
6\end{array}$ & $\begin{array}{l}- \\
\overline{-} \\
\overline{-} \\
\overline{-} \\
\overline{-} \\
\overline{-} \\
-\end{array}$ \\
\hline $\begin{array}{l}178-47-1(105-107) \\
178-47(C C) \\
178-48-1(33-35) \\
178-48(C C) \\
178-49-1(69-71) \\
178-49-1(138-141) \\
178-49(\mathrm{CC}) \\
178-50-1(35-37) \\
178-50-2(68-69) \\
178-50-2(132-133)\end{array}$ & $\begin{array}{l}\text { B } \\
\text { B } \\
\text { B } \\
\text { B } \\
\text { B } \\
\text { B } \\
\text { B } \\
\text { R } \\
\text { C } \\
\text { C }\end{array}$ & $\begin{array}{l}- \\
- \\
- \\
- \\
- \\
- \\
- \\
\bar{P} \\
P \\
P\end{array}$ & $\begin{array}{r}0 \\
1 \\
0 \\
0 \\
0 \\
1 \\
0 \\
31 \\
198 \\
419\end{array}$ & $\begin{array}{l}- \\
\overline{-} \\
\overline{-} \\
\overline{-} \\
\overline{-} \\
-\end{array}$ \\
\hline $\begin{array}{l}178-50-2 \text { bottom } \\
178-50-3(18-19) \\
178-51-1(93-95) \\
178-51-2(66-68) \\
178-51-2(124-126) \\
178-51(C C) \\
178-52-2(108-110) \\
178-52-2(141-143) \\
178-52(C C) \\
178-53-1(67-68)\end{array}$ & $\begin{array}{l}\text { B } \\
\text { A } \\
\text { C } \\
\text { B } \\
\text { B } \\
\text { B } \\
\text { A } \\
\text { A } \\
\text { C } \\
\text { B }\end{array}$ & $\begin{array}{l}\bar{P} \\
P \\
- \\
- \\
\bar{P} \\
P \\
P \\
-\end{array}$ & $\begin{array}{r}0 \\
2547 \\
932 \\
0 \\
0 \\
0 \\
1140 \\
3828 \\
3024 \\
0\end{array}$ & $\begin{array}{l}- \\
\overline{-} \\
\overline{-} \\
\overline{-} \\
\overline{-} \\
\overline{-}\end{array}$ \\
\hline $\begin{array}{l}178-53(\mathrm{CC}) \\
178-54-1(34-35) \\
178-54-1(112-113) \\
178-54-1(136-137) \\
178-54-1(146-147) \\
178-54-2(26-27) \\
178-54-2(72-73) \\
178-54-2(109-110) \\
178-54-3(36-37) \\
178-54-3(41-42)\end{array}$ & $\begin{array}{l}\mathrm{R} \\
\mathrm{R} \\
\mathrm{R} \\
\mathrm{R} \\
\mathrm{A} \\
\mathrm{A} \\
\mathrm{C} \\
\mathrm{R} \\
\mathrm{C} \\
\mathrm{R}\end{array}$ & $\begin{array}{l}\mathrm{P} \\
\mathrm{P} \\
\mathrm{P} \\
\mathrm{P} \\
\mathrm{P} \\
\mathrm{P} \\
\mathrm{M} \\
\mathrm{P} \\
\mathrm{M} \\
\mathrm{M}\end{array}$ & $\begin{array}{r}27 \\
121 \\
47 \\
22 \\
3156 \\
1224 \\
936 \\
396 \\
480 \\
95\end{array}$ & $\begin{array}{l}- \\
\overline{-} \\
\overline{-} \\
\overline{-} \\
\overline{-} \\
\overline{-} \\
-\end{array}$ \\
\hline $\begin{array}{l}178-54-3(109-110) \\
178-54-3(126-127) \\
178-54-3(144-145) \\
178-54-4(26-27) \\
178-54-4(143-144) \\
178-54-5(17-18) \\
178-54-5(34-35) \\
178-54-5(45-47) \\
178-56(C C) \\
178-57-1(32)\end{array}$ & $\begin{array}{l}\mathrm{R} \\
\mathrm{R} \\
\mathrm{B} \\
\mathrm{B} \\
\mathrm{B} \\
\mathrm{B} \\
\mathrm{B} \\
\mathrm{B} \\
\mathrm{B} \\
\mathrm{B}\end{array}$ & $\begin{array}{l}\mathrm{P} \\
\mathrm{P} \\
- \\
- \\
- \\
- \\
- \\
- \\
- \\
-\end{array}$ & $\begin{array}{r}45 \\
97 \\
9 \\
0 \\
6 \\
0 \\
0 \\
0 \\
0 \\
0\end{array}$ & $\begin{array}{l}- \\
\overline{-} \\
\overline{-} \\
- \\
- \\
- \\
-\end{array}$ \\
\hline $\begin{array}{l}178-57-1(35) \\
178-57-1(41)\end{array}$ & $\begin{array}{l}\text { B } \\
\text { B }\end{array}$ & - & $\begin{array}{l}0 \\
0\end{array}$ & - \\
\hline
\end{tabular}




\begin{tabular}{|c|c|c|c|c|}
\hline Sample & $\begin{array}{l}\text { Abun- } \\
\text { dance }\end{array}$ & $\begin{array}{l}\text { Preser- } \\
\text { vation }\end{array}$ & $\begin{array}{l}\text { Number of } \\
\text { Individuals }\end{array}$ & $\begin{array}{c}\text { Td } \\
\text { Values }\end{array}$ \\
\hline $179-1-1(146-148)$ & R & M & 136 & 11 \\
\hline $179-1-2(44-46)$ & $\mathrm{C}$ & G & 147 & 14 \\
\hline $179-1-2(119-121)$ & A & G & 1212 & 5 \\
\hline $179-1-3(45-47)$ & A & G & 948 & 3 \\
\hline $179-1-3(114-116)$ & $\mathrm{R}$ & G & 102 & 20 \\
\hline $179-2-1(44-46)$ & $\mathrm{R}$ & G & 193 & 16 \\
\hline $179-2-1(118-120)$ & $\mathrm{R}$ & G & 121 & 12 \\
\hline $179-2-2(8-10)$ & $\mathrm{R}$ & G & 64 & - \\
\hline $179-2-2(120-122)$ & C & G & 708 & - \\
\hline $179-2-3(147-149)$ & $\mathrm{C}$ & $\mathrm{G}$ & 612 & - \\
\hline $179-2-4(68-70)$ & A & G & 1464 & - \\
\hline $179-2-5(93-95)$ & C & G & 271 & 22 \\
\hline $179-2(\mathrm{CC})$ & $\mathrm{C}$ & G & 53 & - \\
\hline $179-3-1(30-32)$ & $\mathrm{C}$ & G & 65 & 5 \\
\hline $179-3-1(120-122)$ & A & G & 2304 & 10 \\
\hline $179-3-2(44-46)$ & $\mathrm{C}$ & G & 552 & 8 \\
\hline $179-3-2(120-122)$ & A & G & 732 & 8 \\
\hline $179-3-3(54-56)$ & $\mathrm{R}$ & M & 11 & - \\
\hline $179-3-3(126-128)$ & $\mathrm{R}$ & G & 121 & - \\
\hline $179-3-4(29-31)$ & $\mathrm{R}$ & G & 81 & - \\
\hline $179-3-4(87-89)$ & $\mathrm{R}$ & G & 71 & - \\
\hline $179-3-5(34-36)$ & $\mathrm{C}$ & G & 428 & 10 \\
\hline $179-3-6(18-20)$ & $\mathrm{C}$ & G & 576 & 15 \\
\hline $179-3-6(135-137)$ & $\mathrm{R}$ & M & 10 & - \\
\hline $179-3(\mathrm{CC})$ & $\mathbf{R}$ & M & 18 & - \\
\hline $179-3(\mathrm{CC})$ & - & - & - & - \\
\hline $179-4-1(118-120)$ & A & G & 792 & 20 \\
\hline $179-4-2(84-86)$ & $\mathrm{R}$ & M & 94 & - \\
\hline $179-4-2(130-132)$ & $\mathrm{R}$ & G & 12 & - \\
\hline $179-4-3(45-47)$ & $\mathrm{R}$ & M & 20 & - \\
\hline $179-4-3(90-92)$ & $\mathrm{R}$ & G & 192 & - \\
\hline $179-4-3(130-132)$ & A & $\mathrm{G}$ & 1080 & 10 \\
\hline $179-4-4(35-37)$ & $\mathrm{C}$ & M & 516 & 10 \\
\hline $179-4-4(118-120)$ & $\mathrm{R}$ & M & 13 & - \\
\hline $179-4(\mathrm{CC})$ & $\mathrm{C}$ & G & 648 & 24 \\
\hline $179-5-1(35-37)$ & $\mathrm{C}$ & G & 612 & 10 \\
\hline $179-5-1(85-87)$ & $\mathrm{C}$ & G & 408 & 5 \\
\hline $179-5-2(43-45)$ & $\mathrm{R}$ & M & 173 & 5 \\
\hline $179-5-2(120-122)$ & $\mathrm{R}$ & M & 117 & - \\
\hline $179-5-3(37-39)$ & $\mathrm{R}$ & M & 10 & - \\
\hline $179-5-3(120-122)$ & $\mathrm{R}$ & M & 8 & - \\
\hline $179-5-4(45-47)$ & $\mathrm{R}$ & M & 17 & - \\
\hline $179-5-4(75-77)$ & $\mathbf{R}$ & $\mathrm{M}$ & 17 & - \\
\hline $179-5-4(120-122)$ & $\mathrm{R}$ & M & 20 & - \\
\hline $179-5-5(45-47)$ & $\mathrm{R}$ & G & 74 & - \\
\hline $179-5-5(68-70)$ & $\mathrm{R}$ & G & 24 & - \\
\hline $179-5-5(120-122)$ & $\mathrm{R}$ & G & 97 & 15 \\
\hline $179-5-6(140-142)$ & $\mathrm{R}$ & G & 94 & 9 \\
\hline $179-5-6(93-95)$ & $\mathrm{R}$ & G & 127 & 10 \\
\hline $179-5-6(113-115)$ & $\mathrm{R}$ & G & 196 & - \\
\hline $179-5(\mathrm{CC})$ & $\mathrm{R}$ & G & 51 & - \\
\hline $179-6-1(37-39)$ & $\mathrm{R}$ & M & 51 & - \\
\hline $179-6-2(35-37)$ & $\mathrm{R}$ & M & 84 & 25 \\
\hline $179-6-2(64-66)$ & $\mathrm{R}$ & M & 50 & - \\
\hline $179-6-2(120-122)$ & $\mathrm{R}$ & M & 59 & 10 \\
\hline $179-6(\mathrm{CC})$ & $\mathrm{R}$ & G & 20 & - \\
\hline $179-6(\mathrm{CC})$ & - & - & - & - \\
\hline $179-7-1(20-22)$ & $\mathrm{R}$ & M & 23 & - \\
\hline $179-7-1(100-102)$ & $\mathrm{C}$ & G & 672 & 20 \\
\hline $179-7-2(65-67)$ & C & G & 492 & 5 \\
\hline $179-7-2(120-122)$ & A & G & 948 & 10 \\
\hline $179-7-3(70-72)$ & $\mathrm{C}$ & G & 540 & 15 \\
\hline $179-7-3(130-132)$ & $\mathrm{C}$ & G & 432 & - \\
\hline $179-7-4(59-61)$ & A & G & 1284 & 19 \\
\hline $179-7-4(76-78)$ & A & G & 1116 & 10 \\
\hline $179-7-4(130-132)$ & $\mathrm{C}$ & G & 756 & 20 \\
\hline $179-7-5(105-107)$ & $\mathrm{C}$ & G & 567 & 5 \\
\hline $179-7-5(133-135)$ & $\mathrm{C}$ & G & 245 & 8 \\
\hline $179-7(\mathrm{CC})$ & $\mathrm{C}$ & G & 492 & 5 \\
\hline $179-7(\mathrm{CC})$ & - & - & - & 5 \\
\hline$\underline{179-8-2(14-16)}$ & $\mathrm{R}$ & $\mathrm{G}$ & 48 & - \\
\hline
\end{tabular}

\begin{tabular}{|c|c|c|c|c|}
\hline Sample & $\begin{array}{l}\text { Abun- } \\
\text { dance }\end{array}$ & $\begin{array}{l}\text { Preser- } \\
\text { vation }\end{array}$ & $\begin{array}{l}\text { Number of } \\
\text { Individuals }\end{array}$ & $\begin{array}{c}\text { Td } \\
\text { Values }\end{array}$ \\
\hline $179-8-2(90-92)$ & $\mathrm{C}$ & M & 78 & 6 \\
\hline $179-8-2(130-132)$ & A & G & 6864 & 4 \\
\hline $179-8-3(40-42)$ & A & G & 1284 & 2 \\
\hline $179-8-3(134-136)$ & $\mathrm{R}$ & M & 94 & 5 \\
\hline $179-8-4(20-21)$ & C & M & 110 & - \\
\hline $179-8-4(120-122)$ & $\mathrm{R}$ & M & 9 & - \\
\hline $179-8-5(139-140)$ & $\mathbf{R}$ & M & 8 & - \\
\hline $179-8-6(84-86)$ & C & M & 63 & - \\
\hline $179-8-6(140-142)$ & R & M & 8 & - \\
\hline $179-8(\mathrm{CC})$ & $\mathrm{R}$ & M & 7 & - \\
\hline $179-8(\mathrm{CC})$ & $\mathrm{R}$ & M & 6 & - \\
\hline $179-9-1(5-7)$ & A & G & 720 & 10 \\
\hline $179-9-1(90-92)$ & A & G & 1068 & 5 \\
\hline $179-9-1(136-138)$ & $\mathrm{R}$ & G & 13 & - \\
\hline $179-9-2(17-19)$ & $\mathrm{C}$ & G & 275 & 5 \\
\hline $179-9-2(50-52)$ & C & G & 514 & - \\
\hline $179-9-2(110-112)$ & A & G & 1152 & 6 \\
\hline $179-9-3(38-40)$ & C & G & 190 & 5 \\
\hline $179-9-4(33-35)$ & C & G & 191 & 2 \\
\hline $179-9-4(140-141)$ & $\mathrm{C}$ & G & 123 & 10 \\
\hline $179-9-5(53-55)$ & $\mathbf{R}$ & G & 123 & 10 \\
\hline $179-9-5(113-115)$ & $\mathrm{C}$ & G & 158 & 2 \\
\hline $179-9-6(56-58)$ & C & G & 148 & 2 \\
\hline $179-9-6(125-127)$ & $\mathrm{C}$ & G & 243 & 10 \\
\hline $179-9(\mathrm{CC})$ & $\mathrm{R}$ & M & 9 & - \\
\hline $179-9(C C)$ & $\mathbf{R}$ & M & 8 & - \\
\hline $179-01(\mathrm{CC})$ & $\mathrm{C}$ & G & 93 & - \\
\hline $179-10-1(134-136)$ & C & G & 30 & - \\
\hline $179-10-2(30-32)$ & $\mathrm{R}$ & M & 6 & - \\
\hline $179-10-2(89-91)$ & $\mathrm{R}$ & M & 1 & - \\
\hline $179-10-2(130-132)$ & $\mathrm{C}$ & G & 33 & - \\
\hline $179-10-3(15-17)$ & $\mathrm{C}$ & G & 94 & - \\
\hline $179-10-3(130-132)$ & $\mathrm{R}$ & G & 16 & - \\
\hline $179-10-4(17-19)$ & $\mathrm{R}$ & G & 111 & 10 \\
\hline $179-10-4(51-53)$ & $\mathbf{R}$ & M & 46 & 2 \\
\hline $179-10(\mathrm{CC})$ & C & G & 61 & 10 \\
\hline $179-10(C C)$ & B & - & 0 & - \\
\hline $179-10(\mathrm{CC})$ & B & - & 0 & - \\
\hline $179-11-1(100-102)$ & B & - & 0 & - \\
\hline $179-11-2(40-42)$ & B & - & 0 & - \\
\hline $179-11-2(132-134)$ & B & - & 0 & - \\
\hline $179-11-3(36-38)$ & B & - & 0 & - \\
\hline $179-11-3(126-127)$ & B & - & 0 & - \\
\hline $179-11-4(20-22)$ & B & - & 0 & - \\
\hline $179-11-4(110-112)$ & B & - & 0 & - \\
\hline $179-11-4(128-130)$ & B & - & 0 & - \\
\hline $179-12-1(135-136)$ & B & - & 0 & - \\
\hline $180-1-1(82-84)$ & $\mathrm{C}$ & G & 540 & 2 \\
\hline $180-1-2(109-110)$ & C & G & 137 & 4 \\
\hline $180-1-3(26-28)$ & $\mathbf{R}$ & M & 96 & 3 \\
\hline $180-1(\mathrm{CC})$ & B & - & 2 & - \\
\hline $180-2-1(135-137)$ & B & - & 1 & - \\
\hline $180-2-2(17-19)$ & $\mathbf{R}$ & $\mathbf{P}$ & 12 & - \\
\hline $180-2-3(64-66)$ & $\mathbf{R}$ & $\mathbf{P}$ & 8 & - \\
\hline $180-2-4(60-62)$ & R & $\mathrm{M}$ & 23 & - \\
\hline $180-2(\mathrm{CC})$ & $\mathbf{R}$ & M & 10 & - \\
\hline $180-3-1(140-142)$ & $\mathrm{R}$ & M & 59 & - \\
\hline $180-3-2(79-80)$ & $\mathbf{R}$ & G & 58 & - \\
\hline $180-4-1(103-105)$ & $\mathrm{R}$ & $\mathbf{P}$ & 14 & - \\
\hline $180-4-2(70-72)$ & $\mathbf{R}$ & P & 10 & - \\
\hline $180-4-3(39-41)$ & $\mathrm{R}$ & $P$ & 47 & - \\
\hline $180-4(C C)$ & $\mathbf{R}$ & $\mathbf{P}$ & 55 & - \\
\hline $180-5-1(129-131)$ & B & - & 5 & - \\
\hline $180-5-2(72-74)$ & $\mathrm{R}$ & M & 60 & - \\
\hline $180-5-3(72-74)$ & $\mathbf{R}$ & $\mathbf{P}$ & 10 & - \\
\hline $180-5-4(70-72)$ & $\mathbf{R}$ & $\mathrm{P}$ & 10 & - \\
\hline $180-5(\mathrm{CC})$ & $\mathrm{R}$ & M & 157 & - \\
\hline $180-6-1(136-138)$ & $\mathrm{R}$ & $\mathbf{P}$ & 18 & - \\
\hline $180-6(\mathrm{CC})$ & B & - & 3 & - \\
\hline $180-7-1(85-87)$ & B & - & 0 & - \\
\hline
\end{tabular}




\begin{tabular}{|c|c|c|c|c|}
\hline Sample & $\begin{array}{l}\text { Abun- } \\
\text { dance }\end{array}$ & $\begin{array}{l}\text { Preser- } \\
\text { vation }\end{array}$ & $\begin{array}{l}\text { Number of } \\
\text { Individuals }\end{array}$ & $\begin{array}{c}\text { Td } \\
\text { Values }\end{array}$ \\
\hline $\begin{array}{l}180-7(\mathrm{CC}) \\
180-8-1(130-132) \\
180-8-2(64-66) \\
180-8-3(30-32) \\
180-8-4(64-66) \\
180-8-5(90-92) \\
180-8(\mathrm{CC})\end{array}$ & $\begin{array}{l}\mathrm{B} \\
\mathrm{R} \\
\mathrm{R} \\
\mathrm{R} \\
\mathrm{R} \\
\mathrm{R} \\
\mathrm{B}\end{array}$ & $\begin{array}{l}- \\
P \\
P \\
P \\
P \\
P \\
-\end{array}$ & $\begin{array}{r}6 \\
20 \\
29 \\
29 \\
17 \\
18 \\
1\end{array}$ & $\begin{array}{l}- \\
- \\
- \\
- \\
- \\
-\end{array}$ \\
\hline $\begin{array}{l}180-9-1(146-148) \\
180-9(C C) \\
180-10(C C) \\
180-11(C C) \\
180-12-1(98-100) \\
180-12-2(84-86) \\
180-12-2(100-102) \\
180-12(C C) \\
180-13(C C) \\
180-15-1(95-97)\end{array}$ & $\begin{array}{l}\mathrm{R} \\
\mathrm{R} \\
\mathrm{R} \\
\mathrm{R} \\
\mathrm{R} \\
\mathrm{R} \\
\mathrm{R} \\
\mathrm{R} \\
\mathrm{B} \\
\mathrm{R}\end{array}$ & $\begin{array}{l}\mathrm{M} \\
\mathrm{P} \\
\mathrm{M} \\
\mathrm{P} \\
\mathrm{M} \\
\mathrm{M} \\
\mathrm{M} \\
\mathrm{M} \\
- \\
\mathrm{M}\end{array}$ & $\begin{array}{r}51 \\
11 \\
25 \\
12 \\
55 \\
46 \\
67 \\
30 \\
4 \\
19\end{array}$ & $\begin{array}{l}- \\
- \\
- \\
- \\
- \\
- \\
- \\
-\end{array}$ \\
\hline $\begin{array}{l}180-15-2(98-100) \\
180-15(C C) \\
180-16-1(92-94) \\
180-16(C C) \\
180-17-1(90-92) \\
180-17-2(97-99) \\
180-17-3(33-35) \\
180-17-3(98-100) \\
180-17-4(110-112) \\
180-17(\mathrm{CC})\end{array}$ & $\begin{array}{l}\mathrm{R} \\
\mathrm{C} \\
\mathrm{C} \\
\mathrm{R} \\
\mathrm{R} \\
\mathrm{R} \\
\mathrm{R} \\
\mathrm{C} \\
\mathrm{C} \\
\mathrm{C}\end{array}$ & $\begin{array}{l}P \\
G \\
G \\
M \\
M \\
M \\
P \\
G \\
G \\
G\end{array}$ & $\begin{array}{r}20 \\
612 \\
418 \\
324 \\
58 \\
62 \\
26 \\
516 \\
780 \\
516\end{array}$ & $\begin{array}{l}- \\
10 \\
20 \\
15 \\
- \\
- \\
- \\
- \\
- \\
-\end{array}$ \\
\hline $\begin{array}{l}180-18-1(70-72) \\
180-18-2(70-72) \\
180-18-3(83-85) \\
180-18-4(93-95) \\
180-18(C C) \\
180-19-1(95-97) \\
180-19-2(78-80) \\
180-19(C C) \\
180-19 \text { (CC) } \\
180-20-1(112-114)\end{array}$ & $\begin{array}{l}\mathrm{R} \\
\mathrm{R} \\
\mathrm{R} \\
\mathrm{R} \\
\mathrm{C} \\
\mathrm{C} \\
\mathrm{C} \\
\mathrm{C} \\
\mathrm{B} \\
\mathrm{B}\end{array}$ & $\begin{array}{l}M \\
G \\
G \\
G \\
G \\
G \\
G \\
G \\
- \\
-\end{array}$ & $\begin{array}{r}146 \\
115 \\
222 \\
199 \\
780 \\
1260 \\
335 \\
408 \\
0 \\
0\end{array}$ & $\begin{array}{l}- \\
- \\
- \\
- \\
- \\
- \\
- \\
-\end{array}$ \\
\hline $\begin{array}{l}180-20-2(120-122) \\
180-20-3(100-102) \\
180-20-4(40-42) \\
180-20-4(86-88) \\
180-20-5(80-82) \\
180-20(C C) \\
180-21(C C) \\
180-22-1(85-87) \\
180-22-2(56-58) \\
180-22-3(60-62)\end{array}$ & $\begin{array}{l}\mathrm{R} \\
\mathrm{R} \\
\mathrm{R} \\
\mathrm{C} \\
\mathrm{A} \\
\mathrm{R} \\
\mathrm{R} \\
\mathrm{R} \\
\mathrm{B} \\
\mathrm{B}\end{array}$ & $\begin{array}{l}M \\
M \\
P \\
G \\
G \\
M \\
P \\
P \\
- \\
-\end{array}$ & $\begin{array}{r}84 \\
420 \\
47 \\
420 \\
2952 \\
247 \\
28 \\
17 \\
0 \\
0\end{array}$ & $\begin{array}{l}- \\
- \\
- \\
- \\
- \\
- \\
- \\
- \\
-\end{array}$ \\
\hline $\begin{array}{l}180-22-4(56-58) \\
180-22-5(44-46) \\
180-22-6(40-42) \\
180-22(C C) \\
180-23-1(112-114) \\
180-23-2(57-59) \\
180-23-3(64-66) \\
180-23-4(60-62) \\
180-23(C C) \\
180-24-1(68-70)\end{array}$ & $\begin{array}{l}\text { B } \\
\text { B } \\
\text { B } \\
\text { B } \\
\text { B } \\
\text { B } \\
\text { B } \\
\text { B } \\
\text { R } \\
\text { B }\end{array}$ & $\begin{array}{l}- \\
- \\
- \\
- \\
- \\
- \\
- \\
\bar{P} \\
-\end{array}$ & $\begin{array}{r}0 \\
0 \\
0 \\
0 \\
0 \\
0 \\
0 \\
0 \\
21 \\
2\end{array}$ & $\begin{array}{l}- \\
- \\
- \\
- \\
- \\
- \\
- \\
-\end{array}$ \\
\hline $\begin{array}{l}180-24-2(68-70) \\
180-24-3(64-66) \\
180-24-4(44-46) \\
180-24(C C) \\
180-25-1(112-114) \\
180-25(C C)\end{array}$ & $\begin{array}{l}\mathrm{B} \\
\mathrm{R} \\
\mathrm{R} \\
\mathrm{R} \\
\mathrm{R} \\
\mathrm{R}\end{array}$ & $\begin{array}{l}\bar{M} \\
\mathrm{M} \\
\mathrm{M} \\
\mathrm{P} \\
\mathrm{P}\end{array}$ & $\begin{array}{r}4 \\
36 \\
29 \\
80 \\
17 \\
50\end{array}$ & $\begin{array}{l}- \\
- \\
- \\
- \\
-\end{array}$ \\
\hline $\begin{array}{l}181-1-1(70-72) \\
181-1-2(47-49) \\
181-1-3(53-55) \\
181-1-4(70-72) \\
181-1-5(130-132) \\
181-1-6(73-75) \\
181-1(C C) \\
\end{array}$ & $\begin{array}{l}\text { A } \\
\text { B } \\
\text { B } \\
\text { B } \\
\text { R } \\
\mathrm{A} \\
\mathrm{R} \\
\end{array}$ & $\begin{array}{l}\mathrm{G} \\
- \\
- \\
\bar{P} \\
\mathrm{P} \\
\mathrm{G} \\
\mathrm{P}\end{array}$ & & \\
\hline
\end{tabular}

\begin{tabular}{|c|c|c|c|c|}
\hline Sample & $\begin{array}{l}\text { Abun- } \\
\text { dance }\end{array}$ & $\begin{array}{l}\text { Preser- } \\
\text { vation }\end{array}$ & $\begin{array}{l}\text { Number of } \\
\text { Individuals }\end{array}$ & $\begin{array}{c}\text { Td } \\
\text { Values }\end{array}$ \\
\hline $\begin{array}{l}181-2-1(60-62) \\
181-2-2(51-53) \\
181-2-3(21-23)\end{array}$ & $\begin{array}{l}\mathrm{R} \\
\mathrm{R} \\
\mathrm{A}\end{array}$ & $\begin{array}{l}P \\
P \\
G\end{array}$ & & \\
\hline $\begin{array}{l}181-2-4(11-13) \\
181-2-5(84-86) \\
181-2-6(81-83) \\
181-2(C C) \\
181-3-1(81-82) \\
181-3-2(15-17) \\
181-3-3(63-65) \\
181-3-4(75-77) \\
181-3(C C) \\
181-4-1(143-145)\end{array}$ & $\begin{array}{l}\text { B } \\
\text { B } \\
\text { B } \\
\text { B } \\
\text { B } \\
\text { R } \\
\text { R } \\
\text { C } \\
\text { B } \\
\text { B }\end{array}$ & $\begin{array}{l}- \\
- \\
- \\
- \\
- \\
\mathrm{P} \\
\mathrm{M} \\
\mathrm{G} \\
- \\
-\end{array}$ & & \\
\hline $\begin{array}{l}181-4-2(58-60) \\
181-4-3(68-70) \\
181-4-4(70-72) \\
181-4(C C) \\
181-5-1(90-92) \\
181-5-2(68-70) \\
181-5-3(56-58) \\
181-5(C C) \\
181-6-1(114-116) \\
181-6-2(64-66)\end{array}$ & $\begin{array}{l}\text { R } \\
B \\
\text { B } \\
\text { B } \\
B \\
B \\
\text { R } \\
\text { B } \\
\text { R } \\
\text { R }\end{array}$ & $\begin{array}{l}\mathrm{P} \\
- \\
- \\
- \\
- \\
\overline{\mathrm{P}} \\
\overline{\mathrm{M}} \\
\mathrm{P}\end{array}$ & & \\
\hline $\begin{array}{l}181-6-3(103-105) \\
181-6(C C) \\
181-7-1(40-42) \\
181-7-2(68-70) \\
181-7-3(66-68) \\
181-7(C C) \\
181-8-1(33-35) \\
181-8-1(134-136) \\
181-8-2(64-66) \\
181-8-3(63-65)\end{array}$ & $\begin{array}{l}\mathrm{B} \\
\mathrm{R} \\
\mathrm{R} \\
\mathrm{B} \\
\mathrm{B} \\
\mathrm{R} \\
\mathrm{B} \\
\mathrm{B} \\
\mathrm{R} \\
\mathrm{B}\end{array}$ & $\begin{array}{l}\overline{-} \\
\mathrm{P} \\
- \\
\overline{\mathrm{P}} \\
\overline{-} \\
\overline{\mathrm{P}} \\
-\end{array}$ & & \\
\hline $\begin{array}{l}181-8-4(66-68) \\
181-8-5(55-57) \\
181-8(C C) \\
181-9-1(50-52) \\
181-9-1(129-131) \\
181-9-2(35-37) \\
181-9-3(130-132) \\
181-9-4(65-67) \\
181-9(C C) \\
181-10(C C)\end{array}$ & $\begin{array}{l}\mathrm{R} \\
\mathrm{R} \\
\mathrm{B} \\
\mathrm{R} \\
\mathrm{R} \\
\mathrm{C} \\
\mathrm{R} \\
\mathrm{C} \\
\mathrm{R} \\
\mathrm{R}\end{array}$ & $\begin{array}{l}\mathrm{P} \\
\mathrm{P} \\
- \\
\mathrm{P} \\
\mathrm{P} \\
\mathrm{G} \\
\mathrm{M} \\
\mathrm{G} \\
\mathrm{P} \\
\mathrm{P}\end{array}$ & & \\
\hline $\begin{array}{l}181-11-1(43-45) \\
181-11-1(130-132) \\
181-11(C C) \\
181-12-1(132-134) \\
181-12-2(68-70) \\
181-12-3(62-64) \\
181-12-3(119-121) \\
181-12(C C) \\
181-13-1(45-47) \\
181-13-2(45-47)\end{array}$ & $\begin{array}{l}\text { B } \\
\text { B } \\
\text { C } \\
\text { R } \\
\text { R } \\
\text { A } \\
\text { C } \\
\text { C } \\
\text { C } \\
\text { C }\end{array}$ & $\begin{array}{l}- \\
\bar{G} \\
\mathrm{M} \\
\mathrm{M} \\
\mathrm{G} \\
\mathrm{G} \\
\mathrm{G} \\
\mathrm{G} \\
\mathrm{G}\end{array}$ & & \\
\hline $\begin{array}{l}181-13-3(40-42) \\
181-13-4(18-20) \\
181-13-5(30-32) \\
181-13-5(120-122) \\
181-13-6(20-22) \\
181-13-6(130-132) \\
181-13(C C) \\
181-14-1(114-116) \\
181-14-2(40-42) \\
181-14(\mathrm{CC})\end{array}$ & $\begin{array}{l}\mathrm{A} \\
\mathrm{C} \\
\mathrm{R} \\
\mathrm{R} \\
\mathrm{R} \\
\mathrm{R} \\
\mathrm{R} \\
\mathrm{B} \\
\mathrm{C} \\
\mathrm{A}\end{array}$ & $\begin{array}{l}G \\
G \\
G \\
\text { P } \\
P \\
P \\
P \\
- \\
G \\
G\end{array}$ & & \\
\hline $\begin{array}{l}181-15-1(134-136) \\
181-15-2(40-42) \\
181-15-3(20-22) \\
181-15-3(130-132) \\
181-15-5(30-32) \\
181-15-5(40-42) \\
181-15-5(113-115)\end{array}$ & $\begin{array}{l}\mathrm{C} \\
\mathrm{C} \\
\mathrm{C} \\
\mathrm{C} \\
\mathrm{C} \\
\mathrm{C} \\
\mathrm{C}\end{array}$ & $\begin{array}{l}G \\
G \\
G \\
G \\
G \\
G \\
G\end{array}$ & & \\
\hline
\end{tabular}




\begin{tabular}{|c|c|c|c|c|}
\hline Sample & $\begin{array}{l}\text { Abun- } \\
\text { dance }\end{array}$ & $\begin{array}{l}\text { Preser- } \\
\text { vation }\end{array}$ & $\begin{array}{l}\text { Number of } \\
\text { Individuals }\end{array}$ & \begin{tabular}{|c} 
Td \\
Values
\end{tabular} \\
\hline $\begin{array}{l}181-15-5(130-132) \\
181-15(C C) \\
181-16(C C)\end{array}$ & $\begin{array}{l}\mathrm{C} \\
\mathrm{C} \\
\mathrm{R}\end{array}$ & $\begin{array}{l}\mathrm{G} \\
\mathrm{G} \\
\mathrm{M}\end{array}$ & & \\
\hline $\begin{array}{l}181-17-1(136-138) \\
181-17-2(79-81) \\
181-17-3(22-24) \\
181-17-3(120-122) \\
181-17-4(40-42) \\
181-17-5(45-47) \\
181-17-6(35-37) \\
181-17-6(120-122) \\
181-17(C C) \\
181-18-1(130-132)\end{array}$ & $\begin{array}{l}\mathrm{R} \\
\mathrm{R} \\
\mathrm{R} \\
\mathrm{C} \\
\mathrm{C} \\
\mathrm{C} \\
\mathrm{C} \\
\mathrm{R} \\
\mathrm{C} \\
\mathrm{C}\end{array}$ & $\begin{array}{l}M \\
M \\
M \\
G \\
G \\
G \\
G \\
M \\
M \\
G \\
G\end{array}$ & & \\
\hline $\begin{array}{l}181-18-2(20) \\
181-18-2(38-40) \\
181-18-2(51-53) \\
181-18-2(90-92) \\
181-18-3(30-32) \\
181-18-3(116-118) \\
181-18-4(14-16) \\
181-18-4(78-80) \\
181-18(C C) \\
181-19-1(139-140)\end{array}$ & $\begin{array}{l}\text { A } \\
\text { C } \\
\text { A } \\
\text { A } \\
\text { A } \\
\text { A } \\
\text { A } \\
\text { A } \\
\text { B } \\
\text { B }\end{array}$ & $\begin{array}{l}\text { G } \\
G \\
G \\
G \\
G \\
G \\
G \\
G \\
- \\
-\end{array}$ & & \\
\hline $\begin{array}{l}181-19(\mathrm{CC}) \\
181-20-1(46-47) \\
181-20(C C) \\
181-21-1(51-53) \\
181-21(C C) \\
181-22-1(131-132) \\
181-22(C C) \\
181-23-1(125-126) \\
181-23(C C) \\
181-24-1(98-99)\end{array}$ & $\begin{array}{l}\text { B } \\
\text { B } \\
\text { B } \\
\text { C } \\
\text { B } \\
\text { B } \\
\text { B } \\
\text { B } \\
\text { B } \\
\text { B }\end{array}$ & $\begin{array}{l}- \\
- \\
\bar{M} \\
- \\
- \\
- \\
- \\
-\end{array}$ & & \\
\hline $\begin{array}{l}181-24(\mathrm{CC}) \\
181-25-1(116-117) \\
181-25-2(93-94) \\
181-25(\mathrm{CC}) \\
181-26-1(92-93) \\
181-27-1(124-125) \\
181-27-2(38-40) \\
181-28-1(135-137) \\
181-29-1(55-57) \\
181-29-2(34-35)\end{array}$ & $\begin{array}{l}\text { B } \\
\text { B } \\
\text { B } \\
\text { B } \\
\text { B } \\
\text { B } \\
\text { B } \\
\text { B } \\
\text { B } \\
\text { B }\end{array}$ & $\begin{array}{l}- \\
- \\
\overline{-} \\
\overline{-} \\
\overline{-} \\
\overline{-}\end{array}$ & & \\
\hline $\begin{array}{l}181-30-1(33-34) \\
182-1-1(80-82) \\
182-1-2(33-35) \\
182-1-2(95-97) \\
182-1-3(24-26) \\
182-1-4(20-22) \\
182-1-4(121-123) \\
182-1-5(20-22) \\
182-1-5(138-140) \\
182-1-6(22-24) \\
182-1-6(143-145)\end{array}$ & $\begin{array}{l}\text { B } \\
\text { B } \\
\text { B } \\
\text { B } \\
\text { B } \\
\text { B } \\
\text { B } \\
\text { B } \\
\text { B } \\
\text { B } \\
\text { B }\end{array}$ & - & & \\
\hline 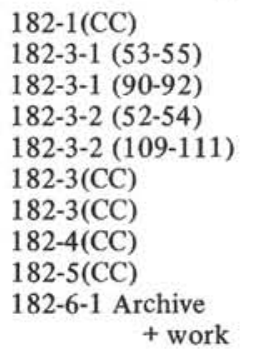 & $\begin{array}{l}\text { B } \\
\text { C } \\
\text { C } \\
\text { C } \\
\text { F } \\
\text { F } \\
\text { F } \\
\text { F } \\
\text { B }\end{array}$ & $\begin{array}{l}\mathrm{G} \\
\mathrm{G} \\
\mathrm{G} \\
\mathrm{G} \\
\mathrm{G} \\
\mathrm{G} \\
\mathrm{M}\end{array}$ & & \\
\hline $\begin{array}{l}182-6(\mathrm{CC}) \\
182 \mathrm{~A}-1(\mathrm{CC})\end{array}$ & $\begin{array}{l}\mathrm{R} \\
\mathrm{R}\end{array}$ & $\begin{array}{l}\mathrm{M} \\
\mathrm{P}\end{array}$ & & \\
\hline
\end{tabular}




\section{PLATES}

Plates 1 through 26 illustrate all taxonomically treated important diatom taxa. References as to where the individuals have been found are included. Most of the illustrated specimens have been circled on their respective slides. Photomicrographs were made with a Leitz Orthoplan Leica set using either Leitz oil apochromat $90 \mathrm{X}$ n. A. 1.4 or Leitz fluorit oil $54 \mathrm{X} \mathrm{n}$. A. 0.95. Bars on the plates represent $10 \mu$. All figures have a magnification of 1500 unless otherwise noted. 
PLATE 1

Magnification 1500X

Figures 1-11 Denticula seminae (Sem.) SIM. and KAN

(1) DSDP 178-12-1(112-114) (2) DSDP 178-12-1(112-114);

(3) DSDP 181-1-6(78-80); (4) DSDP 178-18-2(90-92);

(5) DSDP 182-3-1(53-55); (6) DSDP 182-3-1(53-55);

(7) DSDP 178-1-3(69-71); (8) DSDP 178-1-3(69-71);

(9) DSDP 178-20-2(110-112); (10) DSDP 178-28-4(5-7);

(11) DSDP 178-28-4(5-7);

Figures 12-20 Denticula hyalina nov. spec.

(12) DSDP 178-1-2(109-110); (13) DSDP 173-1-2(109-110);

(14) DSDP 173-8-1(60-61); (15) DSDP 173-8-1(60-61);

(16) DSDP 173-29-2(57-58); (17) DSDP 173-26-3(55-56);

(18) DSDP 173-28-1(100-101); (19) DSDP 173-28-1(100-101);

(20) DSDP 173-26-3(55-56).

Figure $21 \quad$ Denticula hyalina nov. spec. (type).

DSDP 173-26-4(55-56).

Figure 22 Denticula hyalina nov. spec.

DSDP 173-26-4(55-56).

Figures 23, 24 Denticula punctata f. hustedtii nov. forma (type).

(23) DSDP 173-21-1(55-56); (24) DSDP 173-21-1(55-56).

Figures 25,26 Denticula punctata nov. spec.

(25) DSDP 173-21-3(55-56); (26) DSDP 173-21-3(55-56).

Figures 27, 28 Denticula punctata nov. spec. (type).

(27) DSDP 173-21-3(55-56); (28) DSDP 173-21-3(55-56).

Figures 29, 30 Denticula punctata nov. spec.

(29) DSDP 173-20-3(55-56); (30) DSDP 173-29-2(57-59).

Figures 31-35 Denticula nicobarica GRUN.

(31) DSDP 173-29-2(57-59); (32) DSDP 173-29-2(57-59);

(33) DSDP 173-29-2(57-59); (34) DSDP 173-29-2(57-59);

(35) DSDP 173-24-1(105-106).

Figure 36 Denticula seminae (Sem.) SIM. and KAN. DSDP 173-2-4(104-105).

Figures 37-41 Denticula dimorpha nov. spec.

(37) DSDP 173-20-3(55-56); (38) DSDP 173-20-2(55-56);

(39) DSDP 173-20-3(55-56); (40) DSDP 173-23-2(55-56);

(41) DSDP 173-20-3(55-56).

Figure 42 Denticula dimorpha nov. spec. (type). DSDP 173-20-3(55-56).

Figures 43-46 Denticula dimorpha nov. spec.

(43) DSDP 173-20-2(55-56); (44) DSDP 173-20-2(55-56);

(45) DSDP 173-29-4(55-56); (46) DSDP 173-20-2(55-56).

Figure 47 Denticula seminae (Sem.) SIM. and KAN.

DSDP 173-3-2(55-56). 
PLATE 1

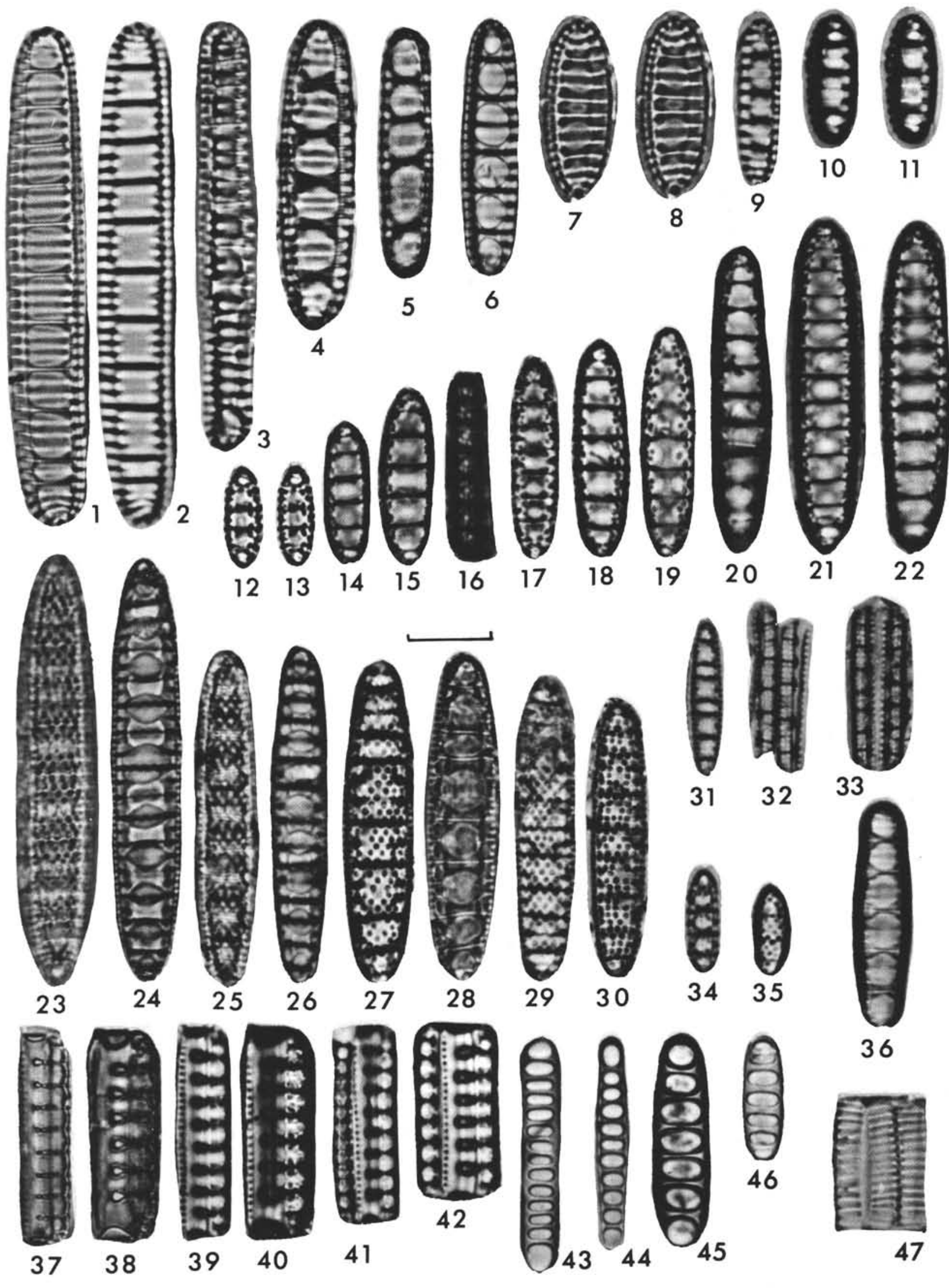


PLATE 2

Magnification 1500X

Figures 1-13

Denticula kamtschatica SABELINA
(1) DSDP 173-7-1(67-68); (2) DSDP 178-37(CC);
(3) DSDP 178-37-4(78-80); (4) DSDP 178-44-4(58-60);
(5) DSDP 178-44-6(21-22); (6) DSDP 173-14-3(55-56);
(7) DSDP 178-45-1(5-6); (8) DSDP 178-37-4(78-80);
(9) DSDP 178-37-4(78-80); (10) DSDP 178-45-1(5-6);
(11) DSDP 173-14-3(55-56); (12) DSDP 178-44(CC);
(13) DSDP 173-13-3(55-56).

Figures 14-24 Denticula lauta BAILEY

(14) DSDP 173-26-3(55-56); (15) DSDP 173-19-4(55-56);

(16) DSDP 173-24-2(55-56); (17) DSDP 173-16-2(55-56);

(18) DSDP 173-20-2(55-56); (19) DSDP 173-20-2(55-56);

(20) DSDP 173-26-3(55-56); (21) DSDP 173-26-3(55-56);

(22) DSDP 173-29-2(57-59); (23) DSDP 173-20-2(55-56);

(24) DSDP 173-7-1(67-68).

Figure 25 Denticula lauta BAILEY (spore?) DSDP 173-28-1(100-101).

Figures 26-28 Denticula miocenica nov. spec. (26-27) DSDP 173-29-2(57-58) type;

(28) DSDP 173-26-3(55-56).

Figures 29-34 Denticula hustedtii SIM. and KAN.

(29) DSDP 173-23-3(55-56); (30) DSDP 173-23-3(55-56);

(31) DSDP 173-18-3(56-57); (32) DSDP 173-18-5(55-56);

(33) DSDP 173-17-3(103-104); (34) DSDP 173-17-3(103-104).

Figure 35 Denticula lauta BAILEY (a typical specimen) DSDP 173-22-1(101-102).

Figures 36-47 Denticula hustedtii SIM. and KAN.

(36) DSDP 173-28-1(100-101); (37) DSDP 173-28-1(100-101);

(38) DSDP 173-18-3(56-57); (39) DSDP 173-18-3(56-57);

(40) DSDP 173-15-4(55-56); (41) DSDP 173-15-4(55-56);

(42) DSDP 173-24-1(105-106); (43) DSDP 173-26-1(120-121);

(44) DSDP 173-24-1(105-106); (45) DSDP 173-25-1(35-36);

(46) DSDP 173-24-1(105-106); (47) DSDP 173-19-2(55-56). 
PLATE 2

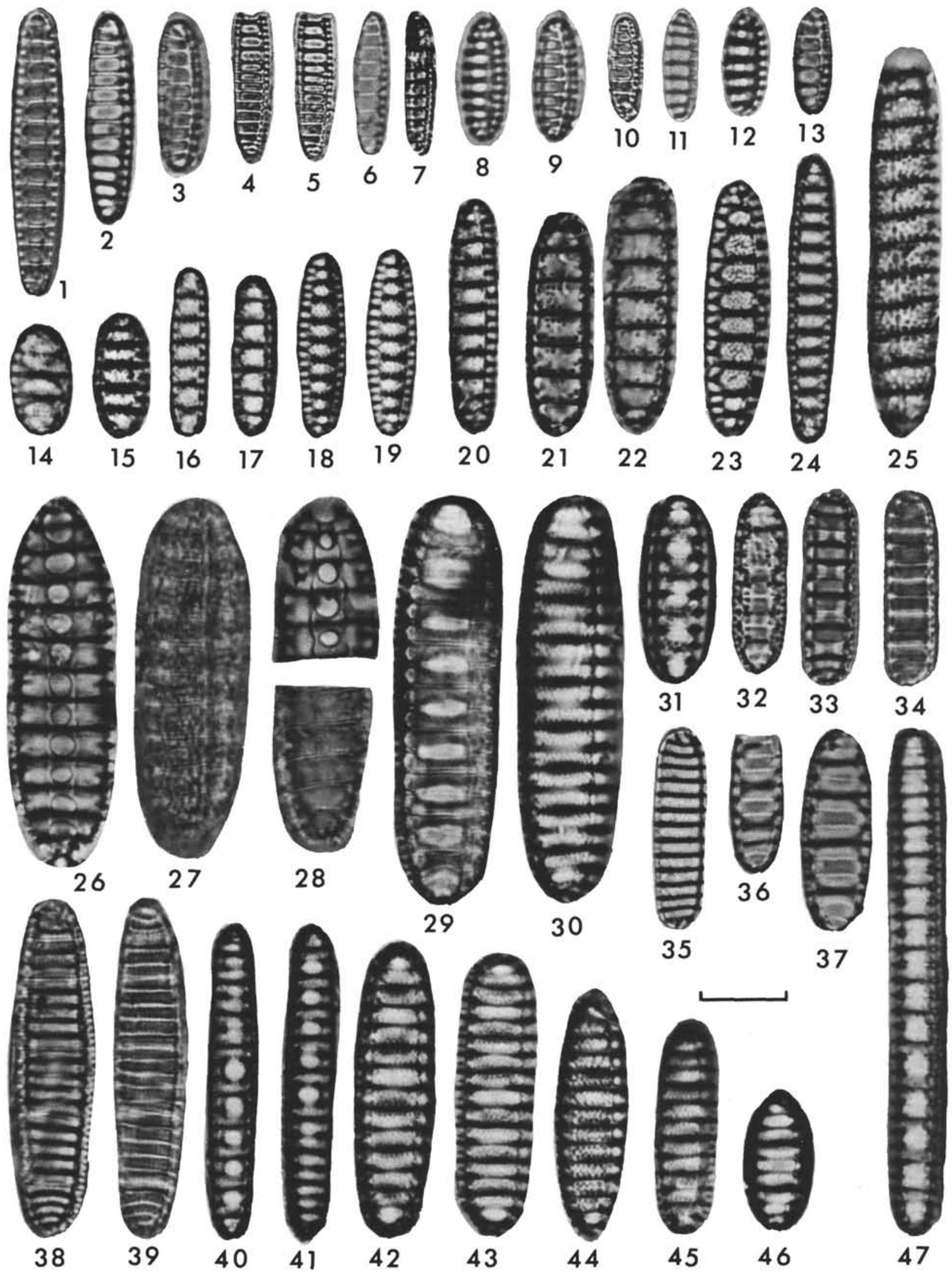


PLATE 3

Magnification 1500X

Figures 1,2 Coscinodiscus praepaleaceus nov. spec. (type).

(1) DSDP 173-17-3(55-56); (2) DSDP 173-17-3(55-56).

Figures 3-9 Coscinodiscus praepaleaceus nov. spec.

(3) DSDP 173-22-2(55-56); (4) DSDP 173-22-1(101-102);

(5) DSDP 173-24-1(105-106); (6) DSDP 173-21-3(55-56);

(7) DSDP 173-24-1(105-106); (8) DSDP 173-22-1(101-102);

(9) DSDP 173-21-3(55-56):

Figures 10-12 Coscinodiscus paleaceus (GRUN.) RATT.

(10) DSDP 173-22-1(10-11); (11) DSDP 173-22-1(10-11);

(12) DSDP 173-22-1(101-102).

Figure 13 Mediaria splendida SHESHUK. forma tenera (type).

DSDP 173-23-2(55-56).

Figures 14, 15 Mediaria splendida SHESHUK.

(14) DSDP 173-23-2(55-56); (15) DSDP 173-24-1(105-106).

Figures 16, 17 Denticula punctata nov. spec.

(16) DSDP 173-28-2(44-45); (17) DSDP 173-28-2(44-45).

Figures 18-20 Rouxia californica M. PERAG.

(18) DSDP 173-17-2(55-56); (19) DSDP 173-18-4(56-57);

(20) DSDP 173-18-3(56-57).

Figure $21 \quad$ Rouxia yabei HANNA.

DSDP 173-17-2(55-56).

Figure 22 Rouxia cf. californica M'PERAG.

DSDP 173-19-2(55-56).

Figure 23 Rouxia yabei HANNA.

DSDP 173-19-3(55-56).

Figures 24, 25 Rouxia diploneides nov. spec. (type).

(24) DSDP 173-25-3(55-56); (25) DSDP 173-25-3(55-56).

Figure 26 Rouxia californica M. PERAG.

DSDP 173-19-2(55-56).

Figures 27-29 Rouxia naviculoides nov. spec.

(27) DSDP 173-25-2(55-56); (28) DSDP 173-25-2(55-56);

(29) DSDP 173-24-1(105-106).

Figure $30 \quad$ Rouxia naviculoides nov. spec. (type). DSDP 173-18-3(56-57).

Figures 31, 32 Rouxia naviculoides nov. spec.

(31) DSDP 173-24-1(105-106); (32) DSDP 173-18-3(56-57). 
PLATE 3

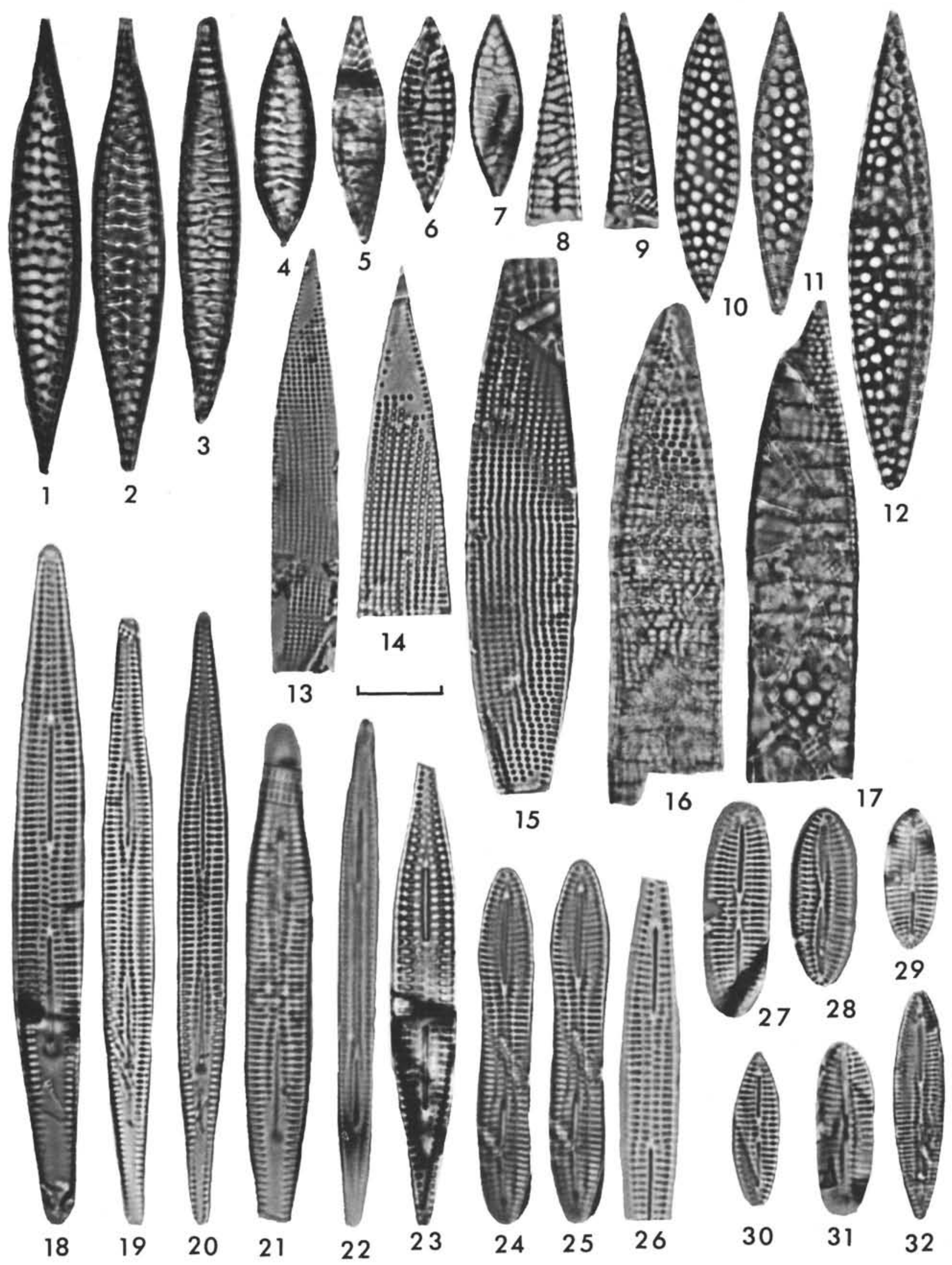


PLATE 4

Magnification $1500 \mathrm{X}$

Figures 1-8 Pseudoeunotia doliolus GRUN.

(1) DSDP 173-9-3(55-56); (2) DSDP 173-5-4(55-56);

(3) DSDP 173-1-1(119-120); (4) DSDP 173-10-5(55-56);

(5) DSDP 173-10-5(55-56); (6) DSDP 173-1-1(119-120);

(7) DSDP 173-1-1(119-120); (8) DSDP 173-1-1(119-120).

Figures 9-11 Nitzschia fossilis (FRENG.) em. KANAYA.

(9) DSDP 173-10-5(55-56); (10) DSDP 173-10-4(55-56);

(11) DSDP 173-10-4(55-56).

Figures 12-16 Nitzschia reinholdii KAN.

(12) DSDP 173-8-1(60-61); (13) DSDP 173-8-1(60-61);

(14) DSDP 173-11-1(55-56); (15) DSDP 173-9-6(55-56);

(16) DSDP 173-5-1(118-119).

Figures 17-19 Nitzschia marina GRUN.

(17) DSDP 173-2-2(43-44); (18) DSDP 173-2-2(43-44);

(19) DSDP 173-2-2(43-44).

Figures 20,21 Nitzschia jouseae BURCKLE.

(20) DSDP 173-15-3(55-56); (21) DSDP 173-15-3(55-56).

Figures 22, 23 Nitzschia jouseae BURCKLE (?).

(22) DSDP 173-21-3(55-56); (23) DSDP 173-21-3(55-56).

Figures 24, 25 Nitzschia fossilis (FRENG.) em. KANAYA.

(24) DSDP 173-16-1(69-70); (25) DSDP 173-16-1(69-70). 
PLATE 4

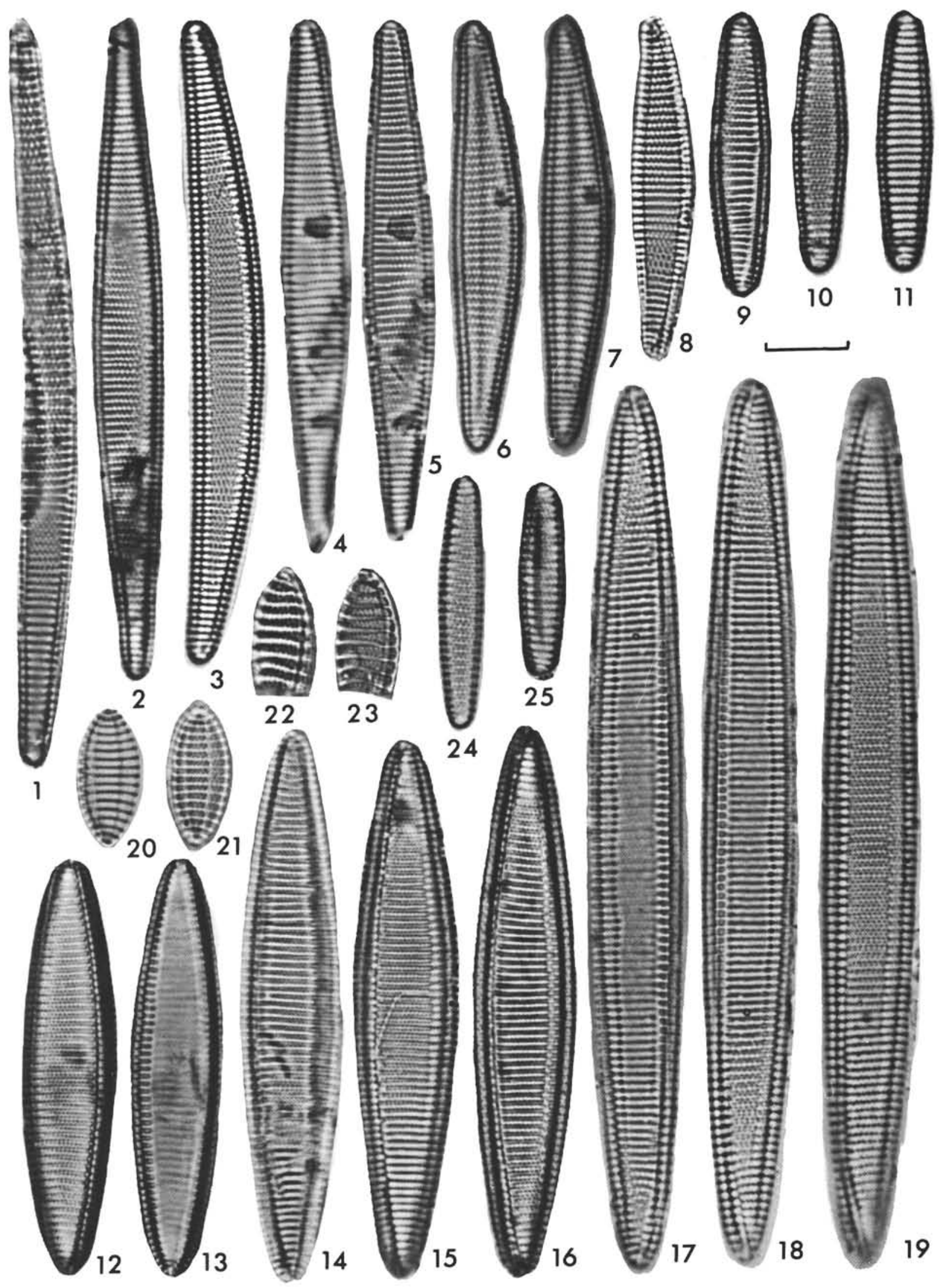


PLATE 5

Magnification 1500X

Figures 1-9 Nitzschia reinholdii KANAYA.

(1) DSDP 173-11-1(55-56); (2) DSDP 173-11-1(55-56);

(3) DSDP 173-14-1(55-56); (4) DSDP 173-14-1(55-56);

(5) DSDP 173-14-1(55-56); (6) DSDP 173-15-3(55-56);

(7) DSDP 173-15-3(55-56); (8) DSDP 173-6-3(55-56);

(9) DSDP 173-6-3(55-56).

Figures 10-12 Nitzschia challengeri nov. spec. (type).

(10) DSDP 173-25-2(55-56); (11) DSDP 173-25-2(55-56); (12) DSDP 173-25-1(95-96).

Figure 13

Nitzschia challengeri nov. spec.(?). DSDP 173-10-6(55-56).

Figure $14 \quad$ Nitzschia challengeri nov. spec. DSDP 173-25-2(55-56).

Figure $15 \quad$ Nitzschia californica nov. spec. DSDP 173-18-4(56-57).

Figures 16-18

Nitzschia species 2 SCHRADER.

(16) DSDP 173-25-1(95-96); (17) DSDP 173-25-1(95-96); (18) DSDP 173-20-3(55-56).

Figure 19

Nitzschia praefossilis nov. spec. DSDP 173-29-2(55-56).

Figure 20

Figures 21, 22

Nitzschia praereinholdii nov. spec. DSDP 173-18-2(55-56).

Figure 23

Nitzschia praefossilis nov. spec. (type)

(21) DSDP 173-18-3(56-57); (22) DSDP 173-18-3(56-57).

Nitzschia praereinholdii nov. spec. (type). DSDP 173-17-3(55-56).

Figures 24, 25

Nitzschia praereinholdii nov. spec. (type).

(24) DSDP 173-16-2(55-56); (25) DSDP 173-16-2(55-56).

Figure 26

Nitzschia praereinholdii nov. spec. DSDP 173-15-2(55-56).

Figure 27

Nitzschia cylindrica BURCKLE. DSDP 173-22-1(101-102).

Figures 28, $29 \quad$ Nitzschia cylindrica BURCKLE (?). (28) DSDP 173-16-1(69-70); (29) DSDP 173-18-2(55-56).

Figure 30

Denticula seminae forma fossilis KOIZUMI DSDP 173-15-2(55-56).

Figure 31

Figures 32,33

Nitzschia rolandii nov. spec. (type). DSDP 173-29(CC).

Figure 34

Nitzschia cylindrica

(32) DSDP 173-29(CC); (33) DSDP 173-16-2(55-56).

Figures 35, 36

Nitzschia challengeri nov. spec. (aberrant) DSDP 173-18-5(55-56).

Figures 37, 38 Nitzschia porteri FRENGUELLI.

(35) DSDP 173-15-2(55-56); (36) DSDP 173-15-4(55-56).

Figures 37, 38

Denticula seminae forma fossilis KOIZUMI.

(37) DSDP 173-15-4(55-56); (38) DSDP 173-15-3(55-56).

Figures 39-41

Nitzschia porteri FRENGUELLI (?) (aberrt.).

(39) DSDP 173-24-1(105-106); (40) DSDP 173-19-2(55-56);

(41) DSDP 173-18-5(55-56).

Figure 42

Nitzschia rolandii nov. spec. DSDP 173-24-4(55-56).

Figures 43, $44 \quad$ Nitzschia porteri FRENGUELLI.

(43) DSDP 173-18-2(55-56); (44) DSDP 173-20-2(55-56). 
PLATE 5

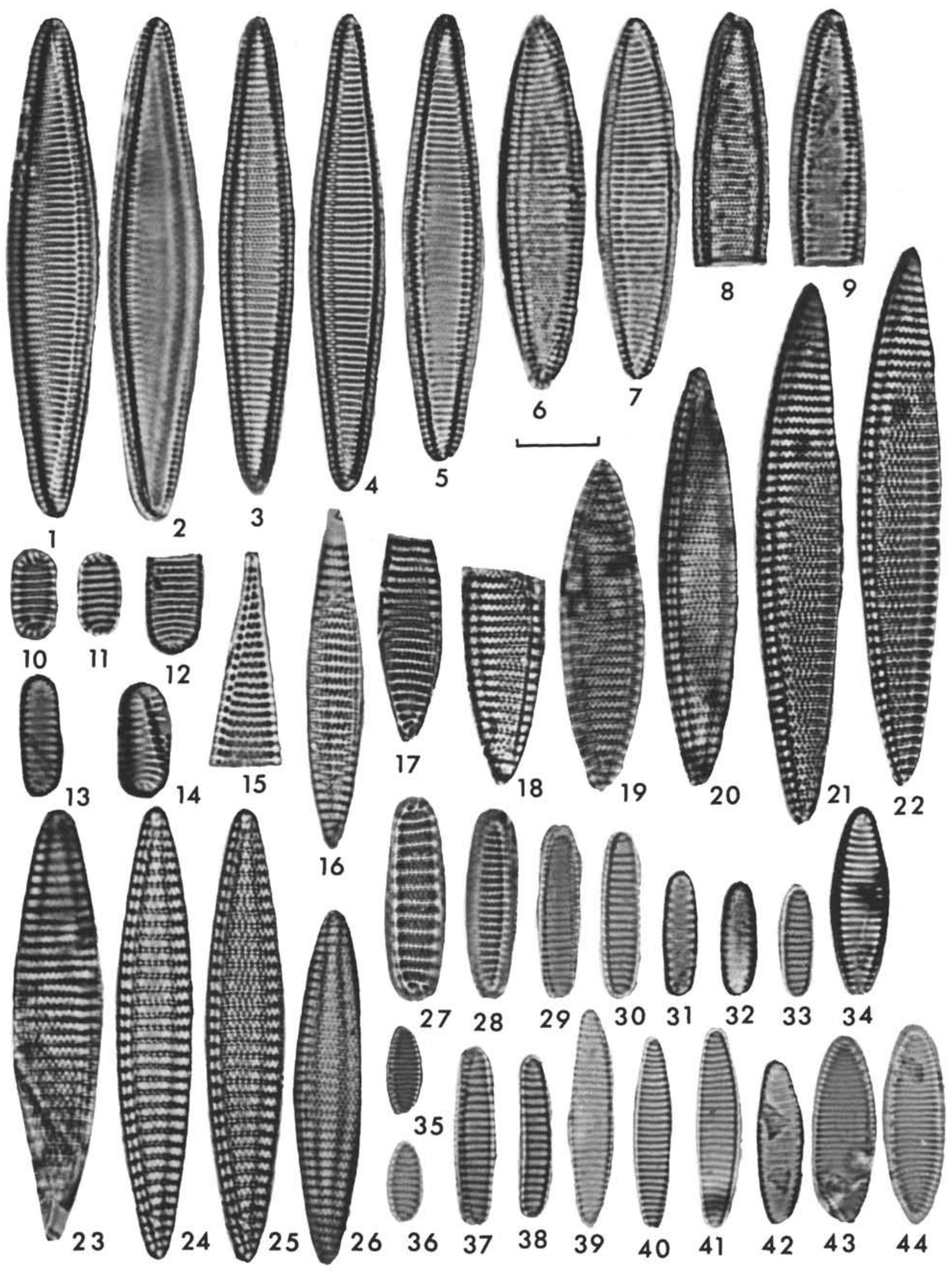


PLATE 6

Magnification $1500 \mathrm{X}$

Figures 1-6 Coscinodiscus yabei KANAYA.

(1) DSDP 173-21-4(55-56); (2) DSDP 173-21-4(55-56);

(3) DSDP 173-21-1(99-100); (4) DSDP 173-21-1(99-100);

(5) DSDP 173-21-4(55-56); (6) DSDP 173-21-4(55-56);

Figures 7-9 Gen. et spec. indet.

(7) DSDP 178-2-1(55-57); (8) DSDP 178-2-1(55-57);

(9) DSDP 178-2-1(55-57).

Figure 10 Coscinodiscus temperei BRUN forma aspinosa. DSDP 173-19-3(55-56).

Figures 11, 12 Coscinodiscus miocenicus nov. spec. (type).

(11) DSDP 173-26-4(55-56); (12) DSDP 173-26-4(55-56).

Figure 13 Coscinodiscus flexuosus BRUN.

DSDP 173-29-1(55-56).

Figure 14 Coscinodiscus temperei BRUN forma aspinosa. DSDP 173-18-4(56-57).

Figure $15 \quad$ Coscinodiscus yabei KANAYA (?).

DSDP 173-22-2(55-56).

Figure 16 Coscinodiscus praeyabei nov. spec. DSDP 173-29-1(55-56).

Figure 17 Coscinodiscus temperei BRUN forma aspinosa (type). DSDP 173-19-3(55-56).

Figures 18,19 Coscinodiscus temperei BRUN.

(18) DSDP 173-21-4(55-56); (19) DSDP 173-22-1(101-102).

Figures 20-22 Gen. et spec. indet.

(20) DSDP 178-2-1(55-57); (21) DSDP 178-2-1(55-57);

(22) DSDP 178-2-1(55-57).

Figure 23 Coscinodiscus plicatus GRUN.

DSDP 173-25-1(35-36).

Figure $24 \quad$ Coscinodiscus lacustris GRUN. (?).

DSDP 173-25-1(95-96). 
PLATE 6

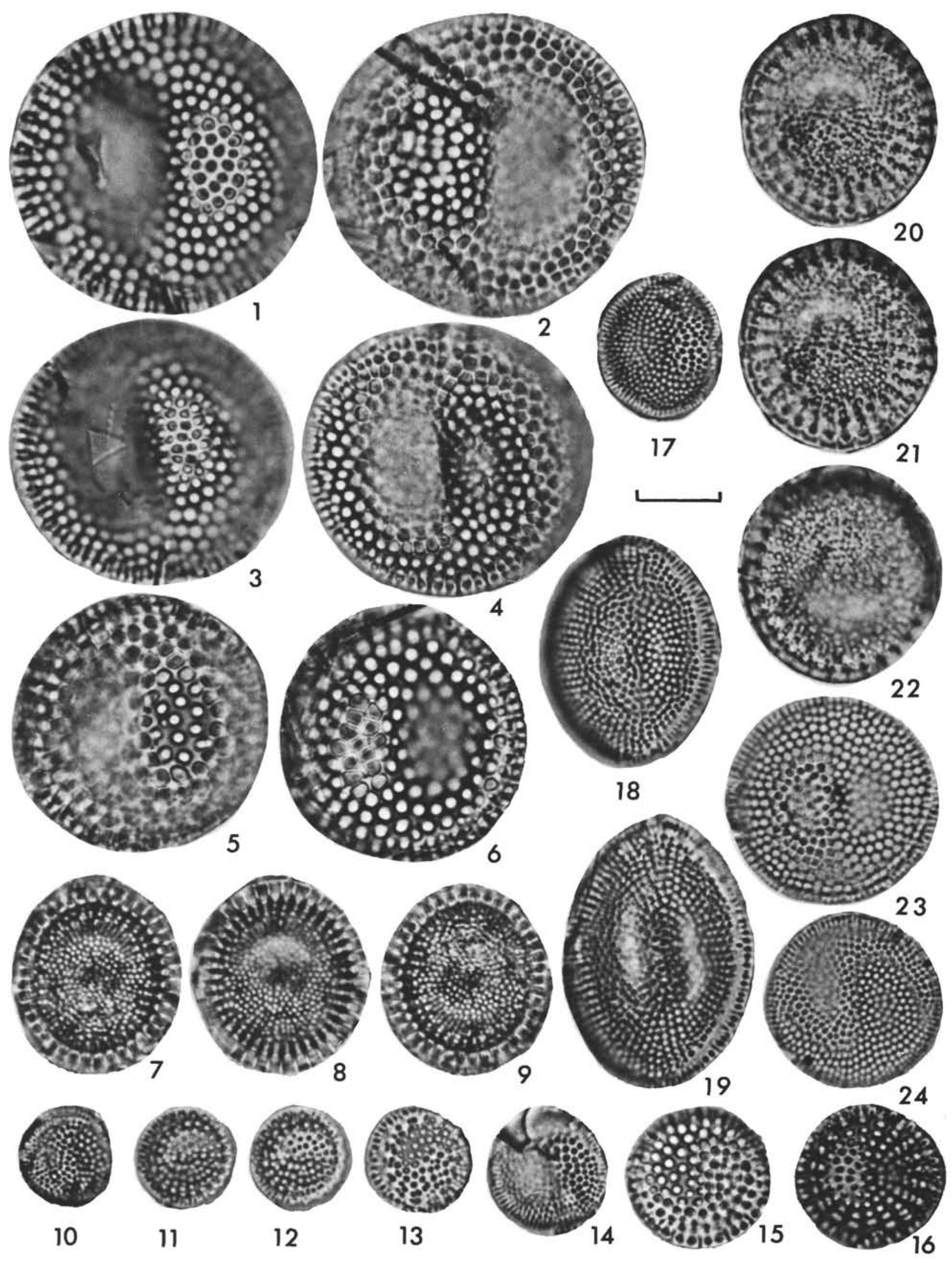




\section{PLATE 7}

Magnification 1500X

Figures 1-5 Coscinodiscus temperei BRUN.

(1) DSDP 173-19-2(55-56); (2) DSDP 173-21-4(55-56);

(3) DSDP 173-21-4(55-56); (4) DSDP 173-21-4(55-56);

(5) DSDP 173-18-4(56-57).

Figures 6,7 Coscinodiscus flexuosus BRUN (?).

(6) DSDP 173-24-4(55-56); (7) DSDP 173-24-4(55-56).

Figures 8,9 Coscinodiscus temperei BRUN.

(8) DSDP 173-21-4(55-56); (9) DSDP 173-21-4(55-56).

Figures 10-13 Coscinodiscus flexuosus BRUN.

(10) DSDP 173-22-1(101-102); (11) DSDP 173-25-3(55-56);

(12) DSDP 173-26-1(120-121); (13) DSDP 173-26-1(120-121).

Figure 14 Coscinodiscus endoi KANAYA.

DSDP 173-19-2(55-56).

Figures 15, 16 Coscinodiscus flexuosus BRUN.

(15) DSDP 173-24-4(55-56); (16) DSDP 173-24-4(55-56).

Figures 17-20 Coscinodiscus praeyabei nov. spec.

(17) DSDP 173-28-1(100-101); (18) DSDP 173-28-1(100-101);

(19) DSDP 173-29-2(57-59); (20) DSDP 173-29-2(57-59).

Figure $21 \quad$ Coscinodiscus endoi KANAYA.

DSDP 173-29-1(55-56).

Figures 22, 23 Coscinodiscus praeyabei nov. spec. (type).

(22) DSDP 173-29-1(55-56); (23) DSDP 173-29-1(55-56). 
Plate 7

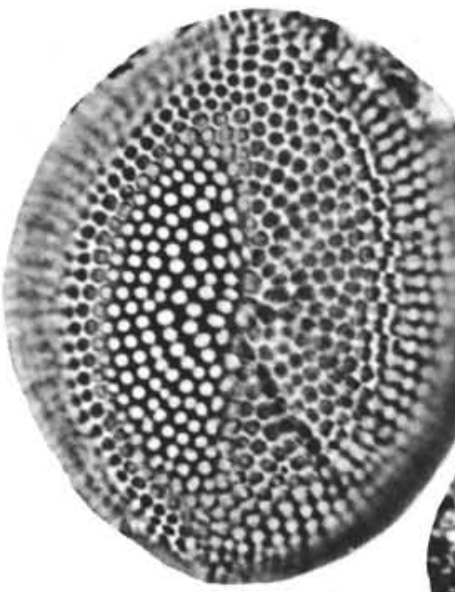

1

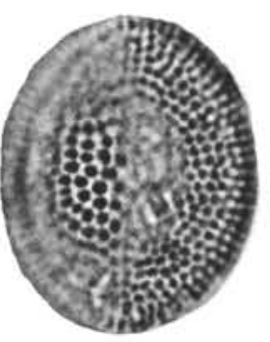

2

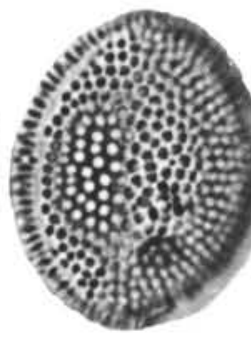

3
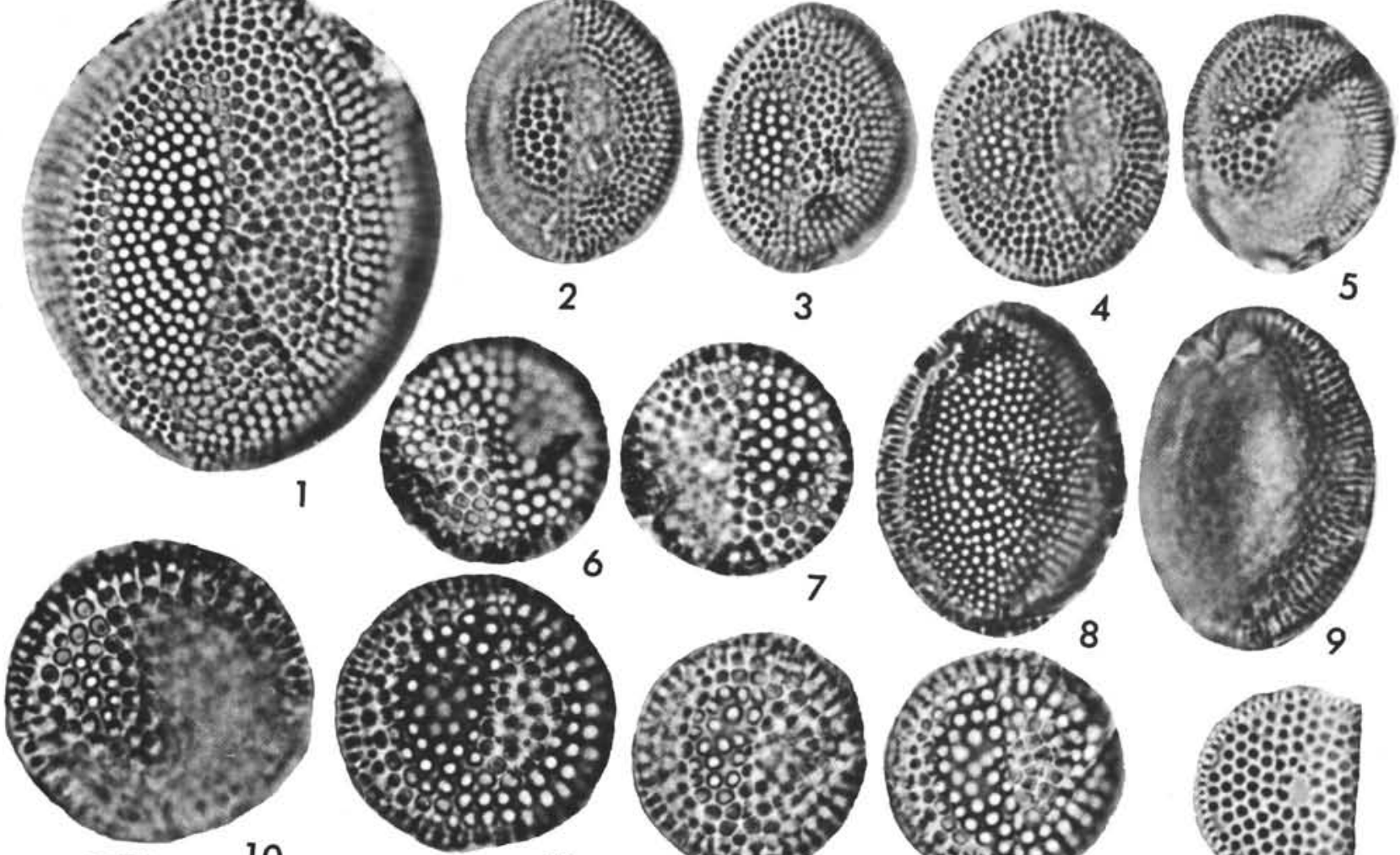

10
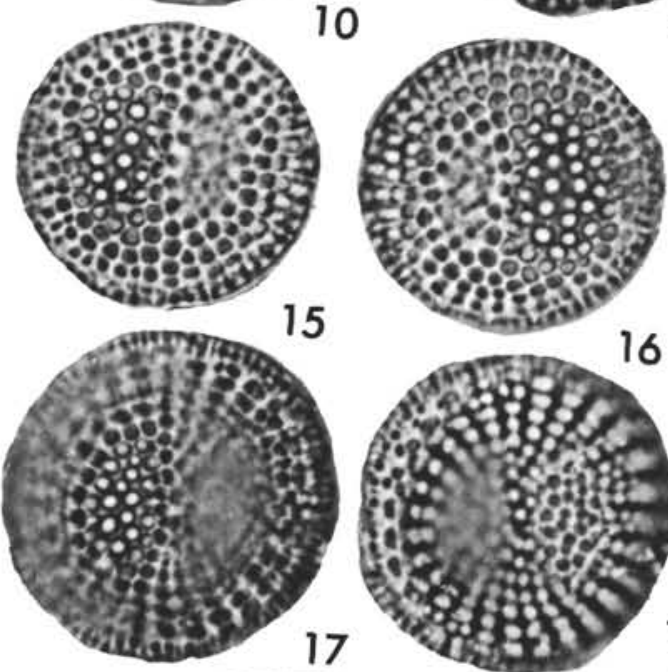

11
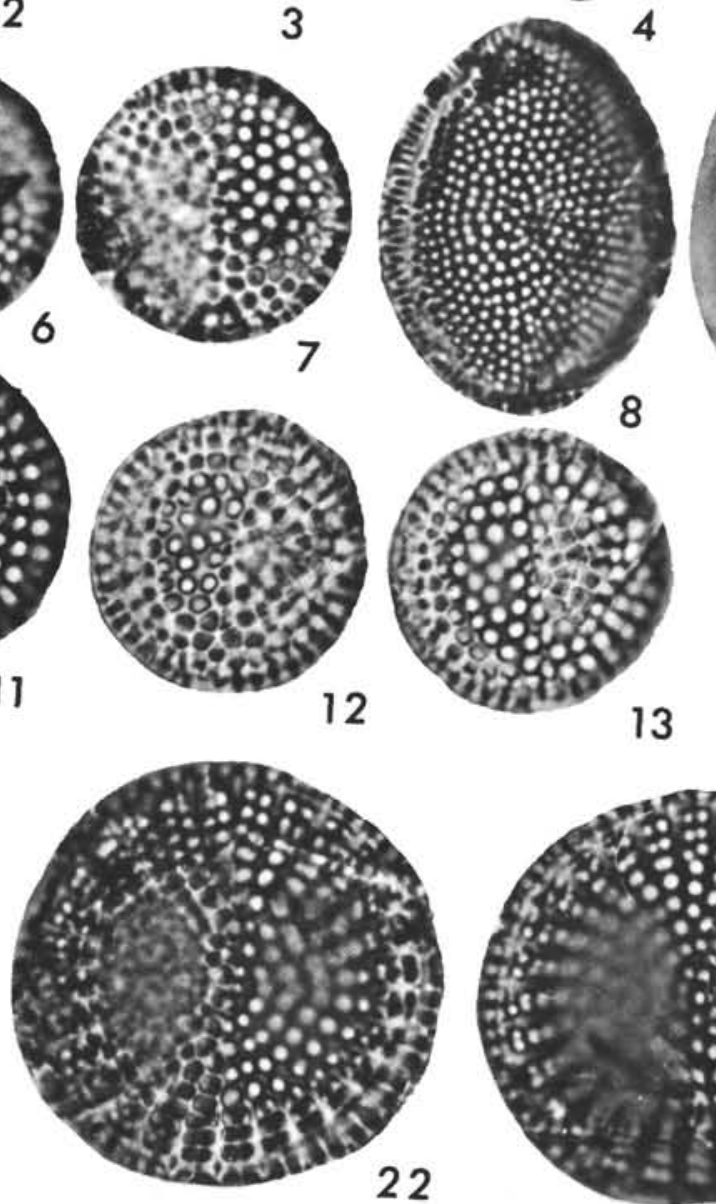

13
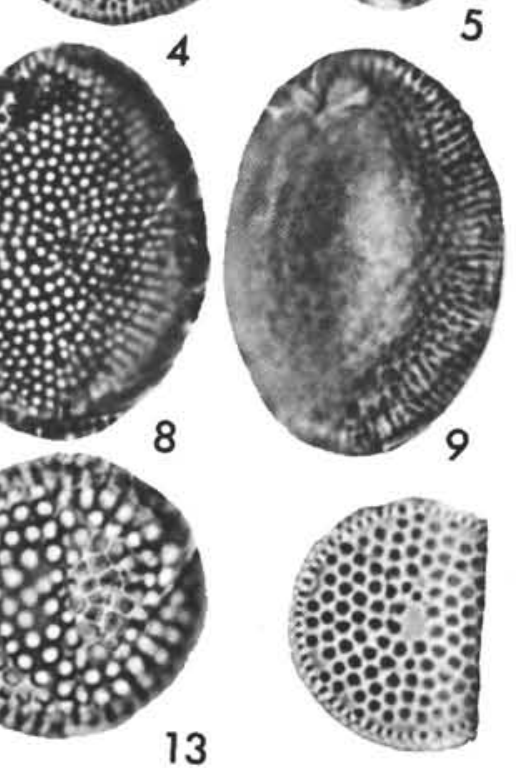

14
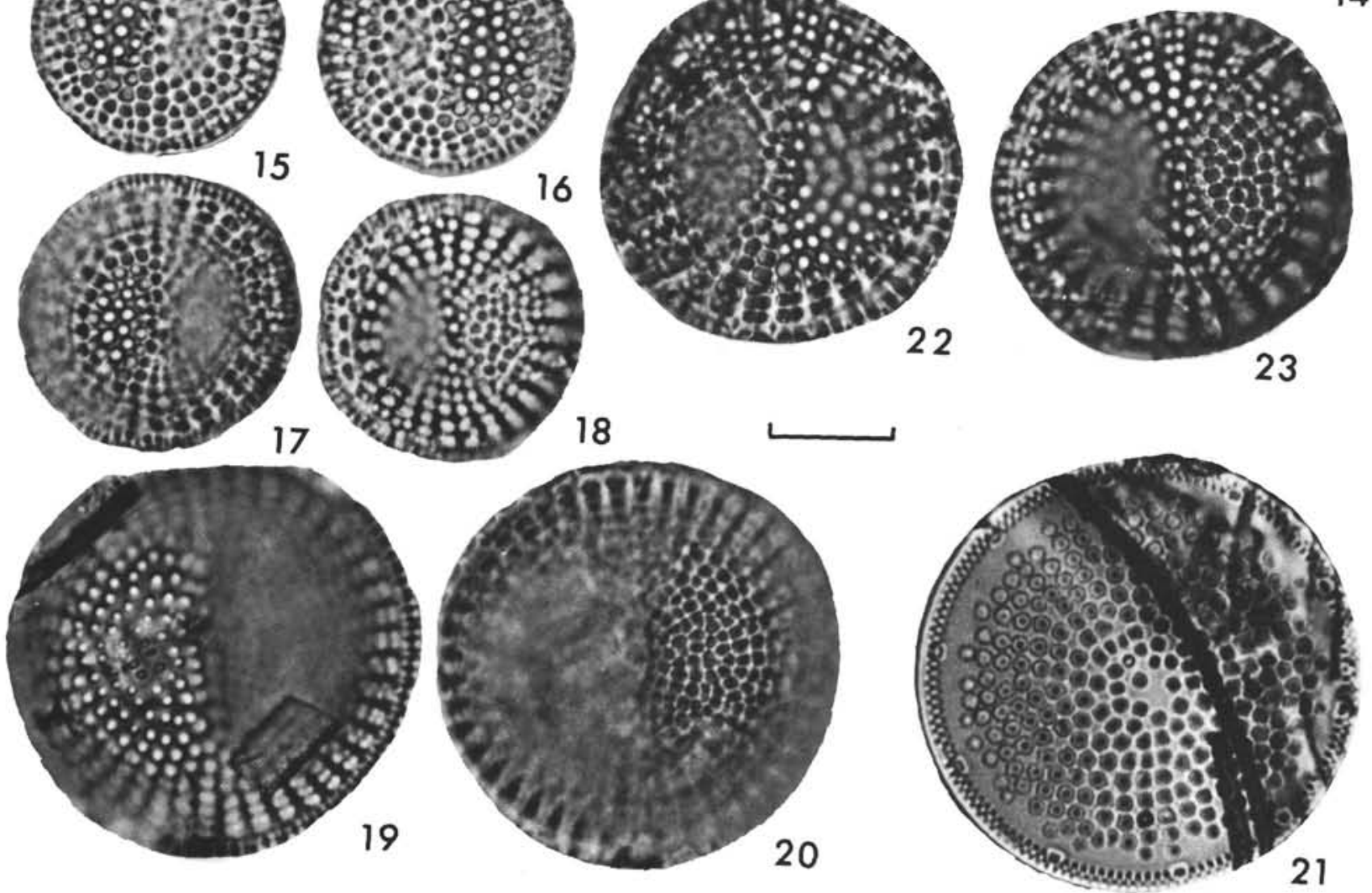
PLATE 8

Magnification $1500 \times$

Figures 1-6 Coscinodiscus lewisianus GREV.

(1) DSDP 173-26-1(120-121); (2) DSDP 173-26-1(120-121);

(3) DSDP 173-29-1(55-56); (4) DSDP 173-29-1(55-56);

(5) DSDP 173-26-1(120-121); (6) DSDP 173-26-1(120-121).

Figures 7-9 Actinocyclus ellipticus GRUN.

(7) DSDP 173-19-2(55-56); (8) DSDP 173-24-1(105-106);

(9) DSDP 173-24-1(105-106).

Figure 10 Coscinodiscus lewisianus GREV. DSDP 173-27-2(55-56).

Figure $11 \quad$ Actinocyclus ellipticus (?) GRUN. DSDP 173-24-1(105-106).

Figures 12-14 Actinocyclus ellipticus GRUN.

(12) DSDP 173-19-2(55-56); (13) DSDP 173-23-2(55-56);

(14) DSDP 173-18-4(56-57).

Figure $15 \quad$ Coscinodiscus lewisianus GREV. DSDP 173-26-1(120-121).

Figures 16-17 Actinocyclus ellipticus GRUN.

(16) DSDP 173-21-4(55-56); (17) DSDP 173-24-1(105-106). 
PLATE 8
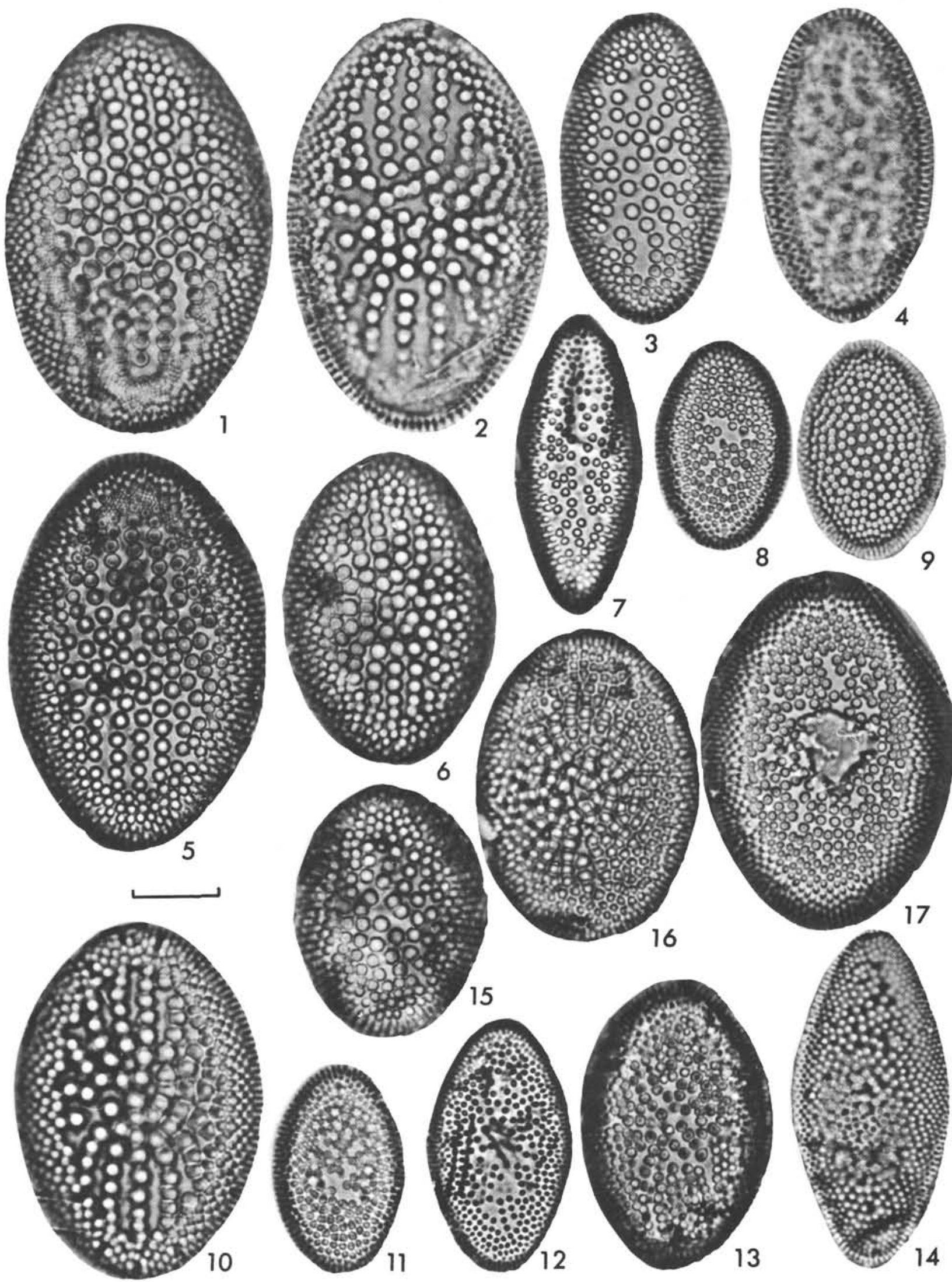
PLATE 9

Magnification 1500X

Figures 1-5 Rhizosolenia bergonii. PERAG

(1) DSDP 173-4-2(55-56); (2) DSDP 173-4-2(55-56);

(3) DSDP 173-12-3(55-56); (4) DSDP 173-12-3(55-56);

(5) DSDP 173-2-4(104-105).

Figure 6 Rhizosolenia praebergonii. nov. spec. DSDP 173-20-2(55-56).

Figures 7,8 Rhizosolenia bergonii $\mathrm{cf}$

(7) DSDP 173-15-2(55-56); (8) DSDP 173-15-2(55-56).

Figure 9 Rhizosolenia styliformis BRIGHTW.(?), (900X)

DSDP 173-1-1(119-120).

Figure 10 Rhizosolenia bergonii. SCHRADER DSDP 173-6-1(105-106).

Figure 11 Rhizosolenia hebetata f. hiemalis GRAN. DSDP 173-20-2(55-56).

Figure 12 Rhizosolenia cf. bergonii. PERAG. DSDP 173-5-4(55-56).

Figures 13-17 Rhizosolenia hebetata f. hiemalis GRAN.

(13) DSDP 173-16-3(55-56); (14) DSDP 173-16-3(55-56);

(15) DSDP 178-10-1(120-122) (900X);

(16) DSDP 181-1-6(78-80); (17) DSDP 178-6-3(130-132).

Figure 18 Rhizosolenia spec. 1. SCHRADER. DSDP 173-29-2(57-59).

Figures 19-21 Rhizosolenia hebetata f. hiemalis. GRAN.

(19) DSDP 173-14-3(55-57); (20) DSDP 173-15-2(55-56);

(21) DSDP 173-15-2(55-56).

Figures 22, 23 Rhizosolenia bergonii. PERAG.

(22) DSDP 173-6-1(105-106); (23) DSDP 173-601(1-5-106)

Figures 24, 25 Rhizosolenia hebetata f. hiemalis GRAN.

(24) DSDP 173-19-4(55-56);

(25) DSDP 173-16-1(69-70) (900X). 
PLATE 9

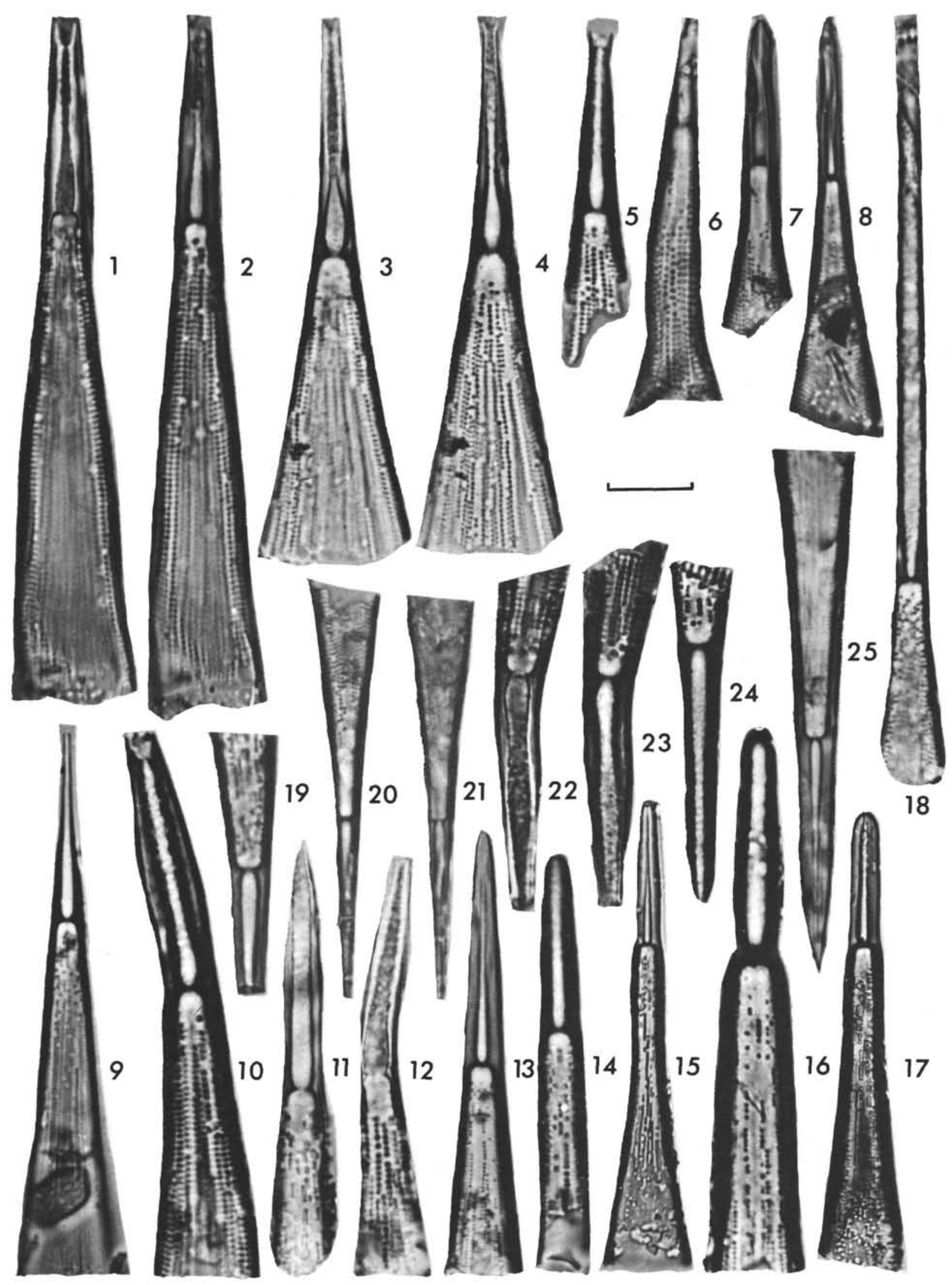


PLATE 10

Magnification $1500 \mathrm{X}$

Figure 1 Rhizosolenia styliformis. BRIGHTW. DSDP 173-2-4(104-105).

Figures 2-6 Rhizosolenia miocenica nov. spec. (type).

(2) DSDP 173-19-2(55-56); (3) DSDP 173-22-2(55-56);

(4) DSDP 173-29-2(57-58); (5) DSDP 173-29-2(57-58);

(6) DSDP 173-26-4(55-56).

Figure 7 Rhizosolenia praebergonii MUCHINA. DSDP 173-19-2(55-56).

Figure $8 \quad$ Rhizosolenia spec. 4. SCHRADER DSDP 173-26-1(120-121).

Figures 9-11 Rhizosolenia miocenica nov. spec.

(9) DSDP 173-29-2(57-58); (10) DSDP 173-22-1(10-11);

(11) DSDP 173-22-1(101-102).

Figure 12 Rhizosolenia alata. BRIGHTW. DSDP 173-2-4(104-105).

Figure 13 Rhizosolenia praealate nov. spec. (type). DSDP 173-18-3(56-57).

Figures 14-17 Rhizosolenia cf. alata.

(14) DSDP 173-20-2(55-56); (15) DSDP 173-14-2(95-96) (900X)

(16) DSDP 173-16-1(69-70); (17) DSDP 173-21-4(55-56).

Figures 18-21 Rhizosolenia styliformis. BRIGHTW.

(18) DSDP 173-1-1(119-120); (19) DSDP 173-1-1(119-120);

(20) DSDP 178-18-2(90-92); (21) DSDP 173-2-5(63-64).

Figure 22 Pseudopyxilla americana (EHR.) FORTI.

DSDP 178-12-1(112-114).

Figure 23 Rhizosolenia cf. alata.

DSDP 173-17-2(55-56).

Figure 24 Rhizosolenia bergonii. PERAG.

DSDP 173-4-3(55-56).

Figure 25 Rhizosolenia spec. 2. SCHRADER.

DSDP 173-25-2(55-56).

Figures 26, 27 Rhizosolenia spec. 3. SCHRADER.

(26) DSDP 173-15-2(55-56); (27) DSDP 173-3-1(43-44).

Figure $28 \quad$ Chaetoceros spec. (bristle). DSDP 173-30(CC).

Figure 29 Rhizosolenia bergonii PERAGALLO. DSDP 173-4-1(54-55). 
PLATE 10

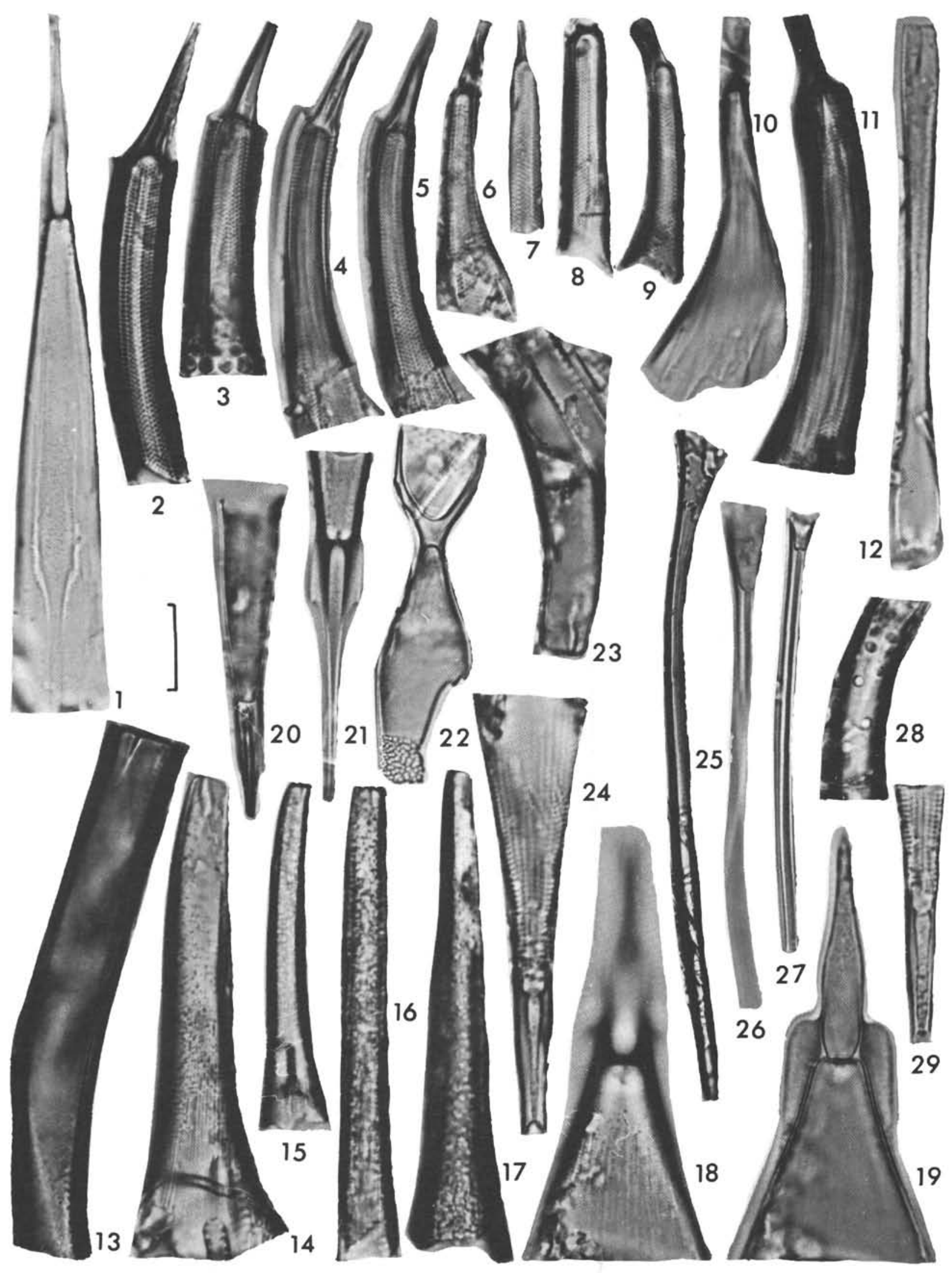


PLATE 11

Magnification 1500X

Figures 1-7 Thalassiosira nidulus (BRUN et TEMP.) JOUSE.

(1) DSDP 173-10-6(55-56); (2) DSDP 182-3-1(90-92);

(3) DSDP 182-3-1(90-92); (4) DSDP 178-10-1(120-122);

(5) DSDP 178-18-2(20-22); (6) DSDP 182-4(CC);

(7) DSDP $182-4(\mathrm{CC})$.

Figures 8, 9 Thalassiosira decipiens JOERG.

(8) DSDP 173-17-3(55-56); (9) DSDP 173-17-3(55-56).

Figures 10-15 Thalassiosira praeconvexa BURCKLE.

(10) DSDP 173-20-3(55-56); (11) DSDP 173-20-3(55-56);

(12) DSDP 173-19-2(55-56); (13) DSDP 173-18-3(56-57);

(14) DSDP 173-19-2(55-56); (15) DSDP 173-19-2(55-56).

Figures 16-22 Thalassiosira oestrupii PROSK.-LAV.

(16) DSDP 173-2-4(104-105); (17) DSDP 173-2-4(104-105);

(18) DSDP 173-4-2(55-56); (19) DSDP 173-4-2(55-56);

(20) DSDP 178-6-4(120-122); (21) DSDP 173-11-1(55-56);

(22) DSDP 173-11-1(55-56).

Figures 23, 24 Thalassiosira nativa SHESH.-POR.

(23) DSDP 173-16-3(55-56); (24) DSDP 173-16-3(55-56).

Figure 25 Thalassiosira antiqua. (GRUN.) CLEVE. DSDP 178-37(CC).

Figures 26-33 Thalassiosira oestrupii PROSK.-LAV.

(26) DSDP 173-10-6(55-56); (27) DSDP 173-10-6(55-56);

(28) DSDP 173-10-6(55-56); (29) DSDP 173-4-1(54-55);

(30) DSDP 173-14-2(95-96); (31) DSDP 173-14-2(95-96);

(32) DSDP 178-40(CC); (33) DSDP 178-40(CC).

Figures 34,35 Thalassiosira decipiens (?).

(34) DSDP 173-19-2(55-56); (35) DSDP 173-19-2(55-56).

Figure 36

Thalassiosira oestrupii PROSK.-LAV. DSDP $178-4(C C)$.

Figure 37 Thalassiosira convexa. MUKHINA. DSDP 173-15-4(55-56).

Figure 38 Thalassiosira convexa. MUKHINA. DSDP 173-15-4(55-56).

Figures 39-41 Thalassiosira oestrupii PROSK.-LAV.

(39) DSDP 173-2-4(42-43). (40) DSDP 173-1-1(119-120);

(41) DSDP 173-1-1(119-120).

Figure 42 Thalassiosira (?) cf. oestrupii PROSK.-LAV. DSDP 173-19-2(55-56).

Figures 43-45 Thalassiosira oestrupii PROSK.-LAV.

(43) DSDP 178-38-1(65-67); (44) DSDP 178-38-1(65-67);

(45) DSDP 173-2-5(63-64). 
PLATE 11
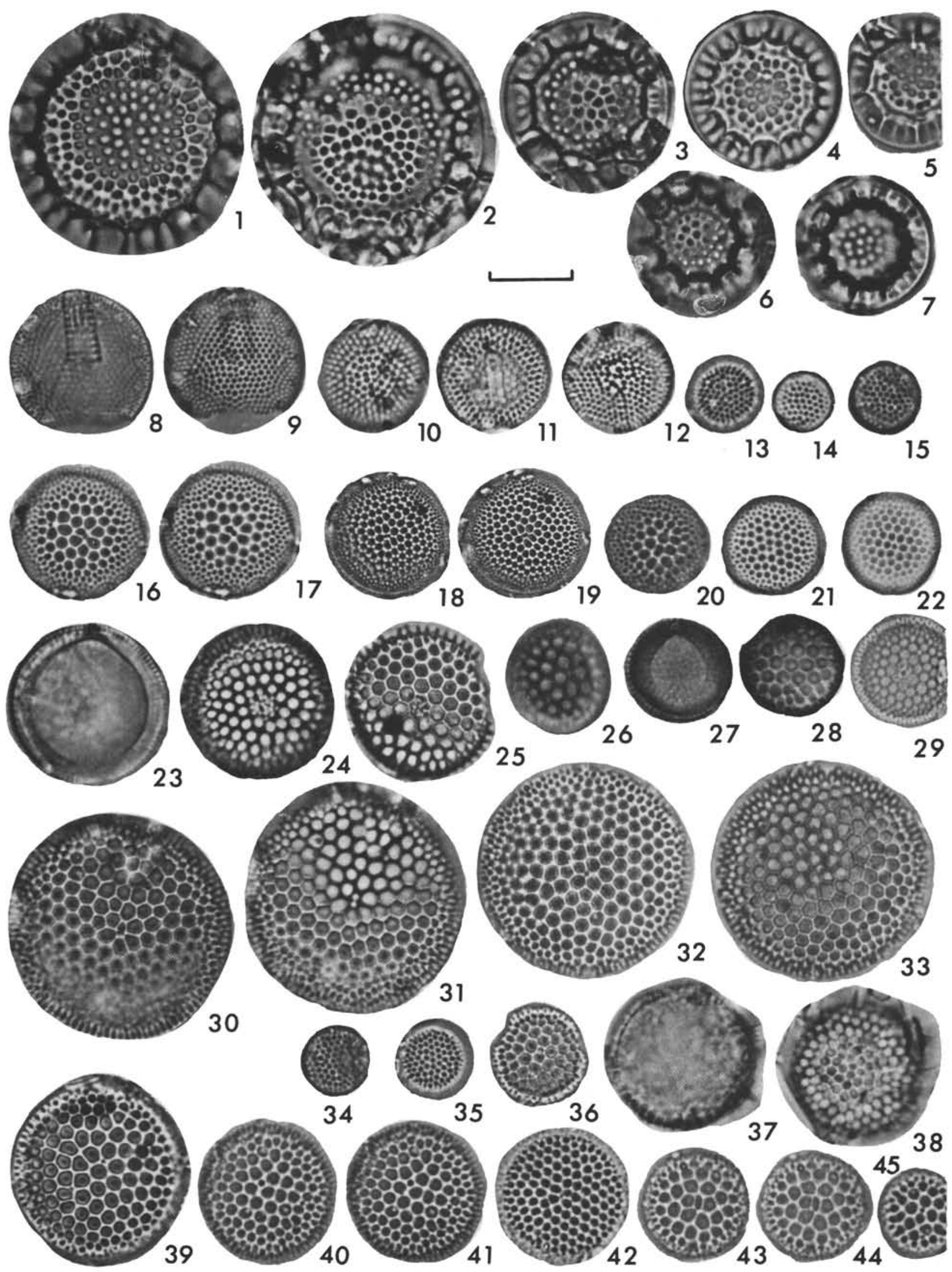
PLATE 12

Magnification $1500 X$

Figures 1-6 Gen. et spec. indet.

(1) DSDP 173-4-1(54-55); (2) DSDP 173-4-1(54-55);

(3) DSDP 173-4-1(54-55); (4) DSDP 173-4-1(54-55);

(5) DSDP 173-4-1(54-55); (6) DSDP 173-4-1(54-55).

Figure $7 \quad$ Lithodesmium minusculum GRUN.(?). DSDP 173-19-3(55-56).

Figure $8 \quad$ Triceratium cinnamomeum GREV. DSDP 173-21-3(55-56).

Figure 9 Triceratium condecorum BRIGHTW. (?). DSDP 173-22-3(55-56).

Figure 10 Rhabdonema japonicum BRUN et TEMP. DSDP 173-26-3(55-56).

Figure 11 Lithodesmium californicum GRUN. DSDP 173-20-2(55-56).

Figure 12 Triceratium spec. 1. SCHRADER. DSDP 173-24-1(105-106).

Figures 13, 14 Trochosira concava SHESH.-POR. (?).

(13) DSDP 173-16-1(69-70); (14) DSDP 173-17-2(55-56).

Figure 15 Lithodesmium minusculum GRUN. DSDP 173-15-3(55-56).

Figure 16 Triceratium spec. 1. SCHRADER. DSDP 173-24-1(105-106).

Figure 17 Lithodesmium minusculum GRUN. DSDP 173-15-4(55-56).

Figures 18, 19 Trochosira spinosa KITT.

(18) DSDP 173-29-2(57-59); (19) DSDP 173-29-2(57-59).

Figure 20 Lithodesmium californicum GRUN. DSDP 173-15-4(55-56).

Figures 21-24 Macrora stella HANNA.

(21) DSDP 173-21-1(55-56); (22) DSDP 173-21-1(55-56);

(23) DSDP 173-22-1(9-10); (24) DSDP 173-22-1(9-10). 
PLATE 12
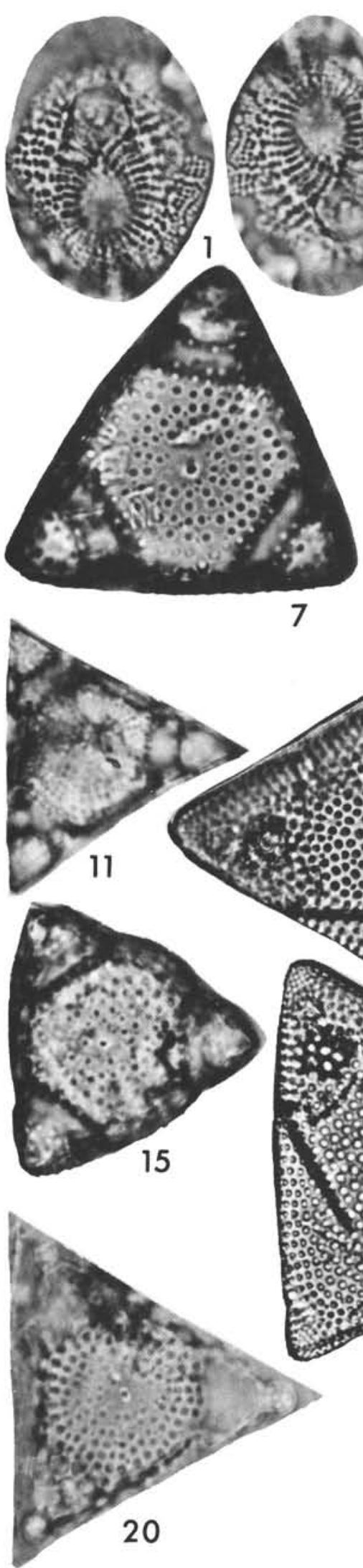

7
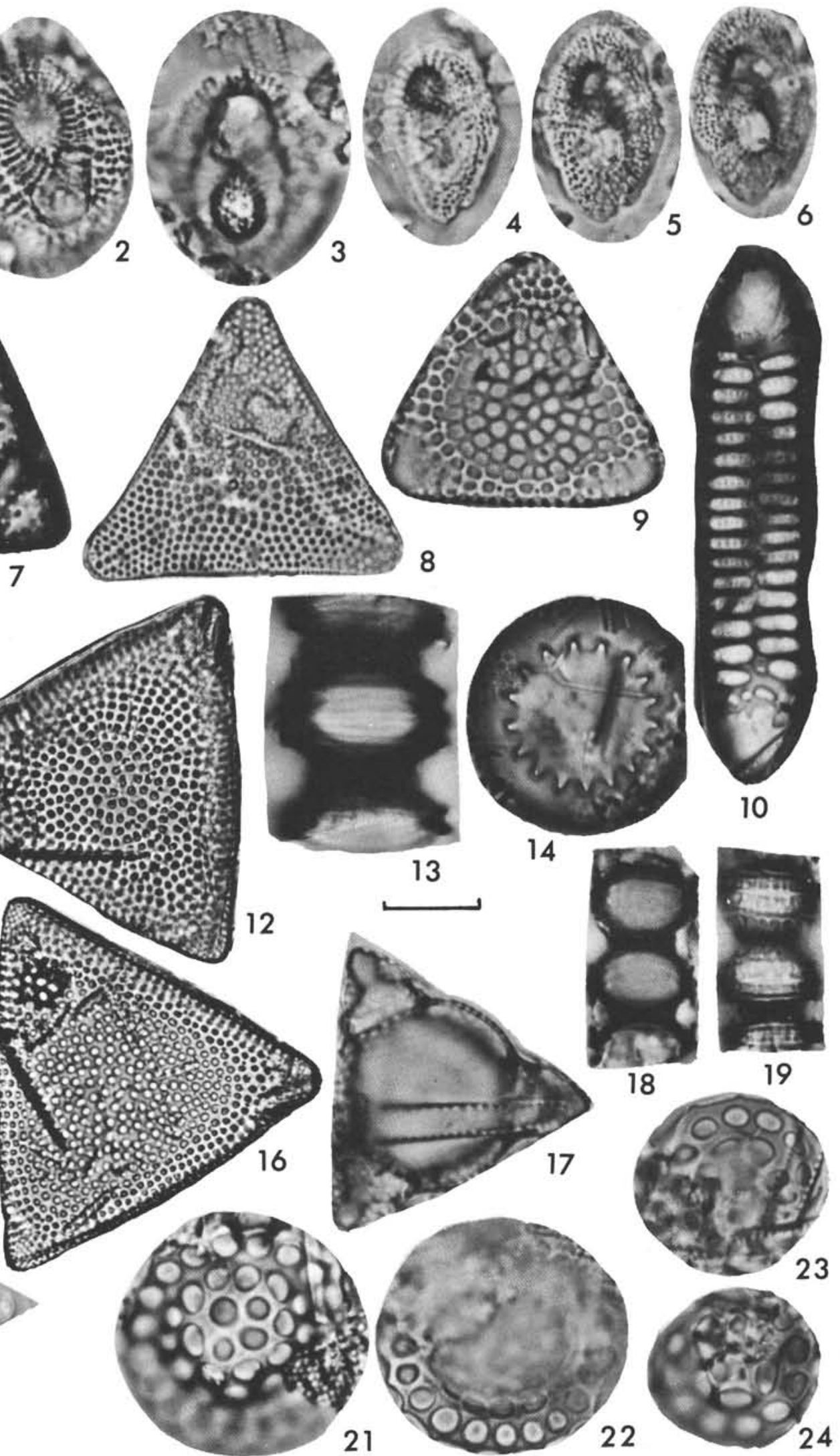

22

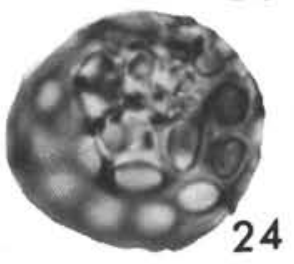


PLATE 13

Magnification 1500X

Figures 1-3 Biddulphia aurita BREB. et GOD.

(1) DSDP 173-2-5(63-64); (2) DSDP 173-1-2(109-110);

(3) DSDP 173-18-2(55-56).

Figures 4-7 Hemiaulus cf. polymorphus

(4) DSDP 173-28-2(4-5); (5) DSDP 173-21-1(55-56);

(6) DSDP 173-29-2(57-59); (7) DSDP 173-16-2(69-70).

Figures 8-10 Hemiaulus spec. 1. SCHRADER.

(8) DSDP 173-22-1(101-102); (9) DSDP 173-22-1(10-11);

(10) DSDP 173-22-1(10-11).

Figure 11 Hemiaulus spec. 2.SCHRADER. DSDP 173-2-4(42-43).

Figure 12 Hemiaulus spec. 3. SCHRADER. DSDP 173-22-1(10-11).

Figures 13, 14 Hemiaulus (?) spec. 4. SCHRADER.

(13) DSDP 173-4-3(55-56); (14) DSDP 173-2-4(42-43).

Figure 15 Biddulphia calamus BRUN et TEMP. DSDP 173-19-2(55-56).

Figure 16 Bruniopsis mirabilis KARST. DSDP 173-24-1(105-106).

Figures 17, 18 Cladogramma dubium LOHMANN.

(17) DSDP 178-38-1(65-67); (18) DSDP 178-38-1(65-67).

Figures 19,20 Stephanodiscus astreae var. minutula GRUN.

(19) DSDP 173-3-2(55-56); (20) DSDP 173-1-4(55-56).

Figure 21 Cladogramma dubium LOHMANN. DSDP 173-22-1(101-102). 
PLATE 13

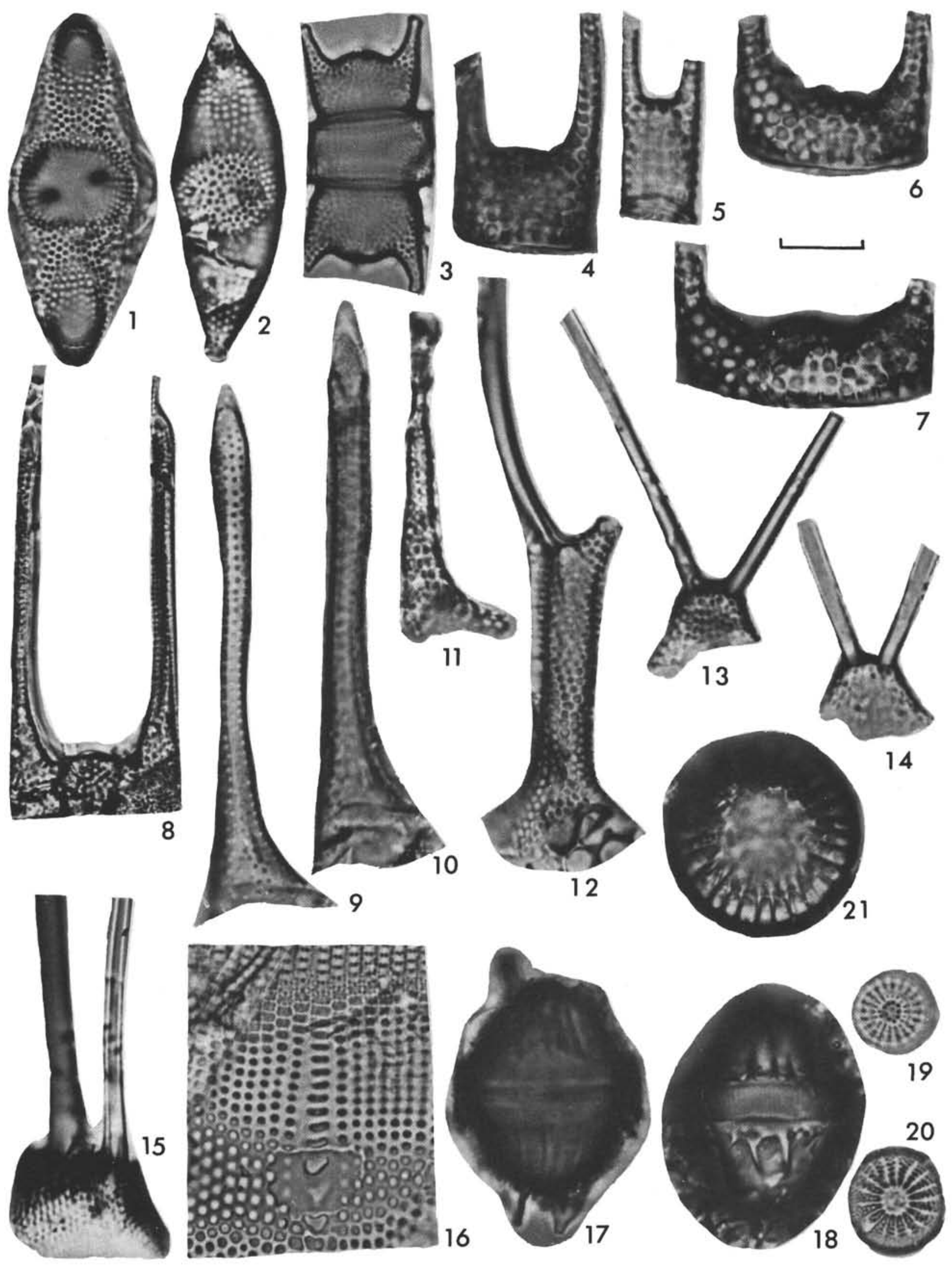




\section{PLATE 14}

Magnification $1500 \mathrm{X}$

Figures 1,2 Thalassiosira zabelinae.

(1) DSDP 178-10-2(45-47); (2) DSDP 178-10-2(45-47).

Figures 3-8 Thalassiosira gravida.

(3) DSDP 178-10-2(45-47); (4) DSDP 178-10-2(45-47);

(5) DSDP 182-3-1(53-55); (6) DSDP 182-3-1(53-55);

(7) DSDP 178-2-1(120-122); (8) DSDP 178-2-1(120-122).

Figures 9-12 Thalassiosira nordenskioeldii CLEVE.

(9) DSDP 173-16-1(69-70); (10) DSDP 182-3-1(53-55);

(11) DSDP 178-9-3(100-102); (12) DSDP 178-16-3(112-114).

Figures 13, 14 Thalassiosira pacifica GRAN. and ANGST (?).

(13) DSDP 178-10-2(45-47); (14) DSDP 178-10-2(45-47).

Figures 15, 16 Thalassiosira spec. 1.

(15) DSDP 173-1-1(119-120); (16) DSDP 173-1-1(119-120).

Figures 17, 18 Thalassiosira spec. 2.

(17) DSDP 173-3-3(104-105); (18) DSDP 173-1-3(105-106)

Figures 19, 20 Thalassiosira spec. 3.

(19) DSDP 173-1-4(55-56); (20) DSDP 173-1-4(55-56).

Figure $21 \quad$ Thalassiosira spec. 4.

DSDP 173-1-3(105-106). 
PLATE 14
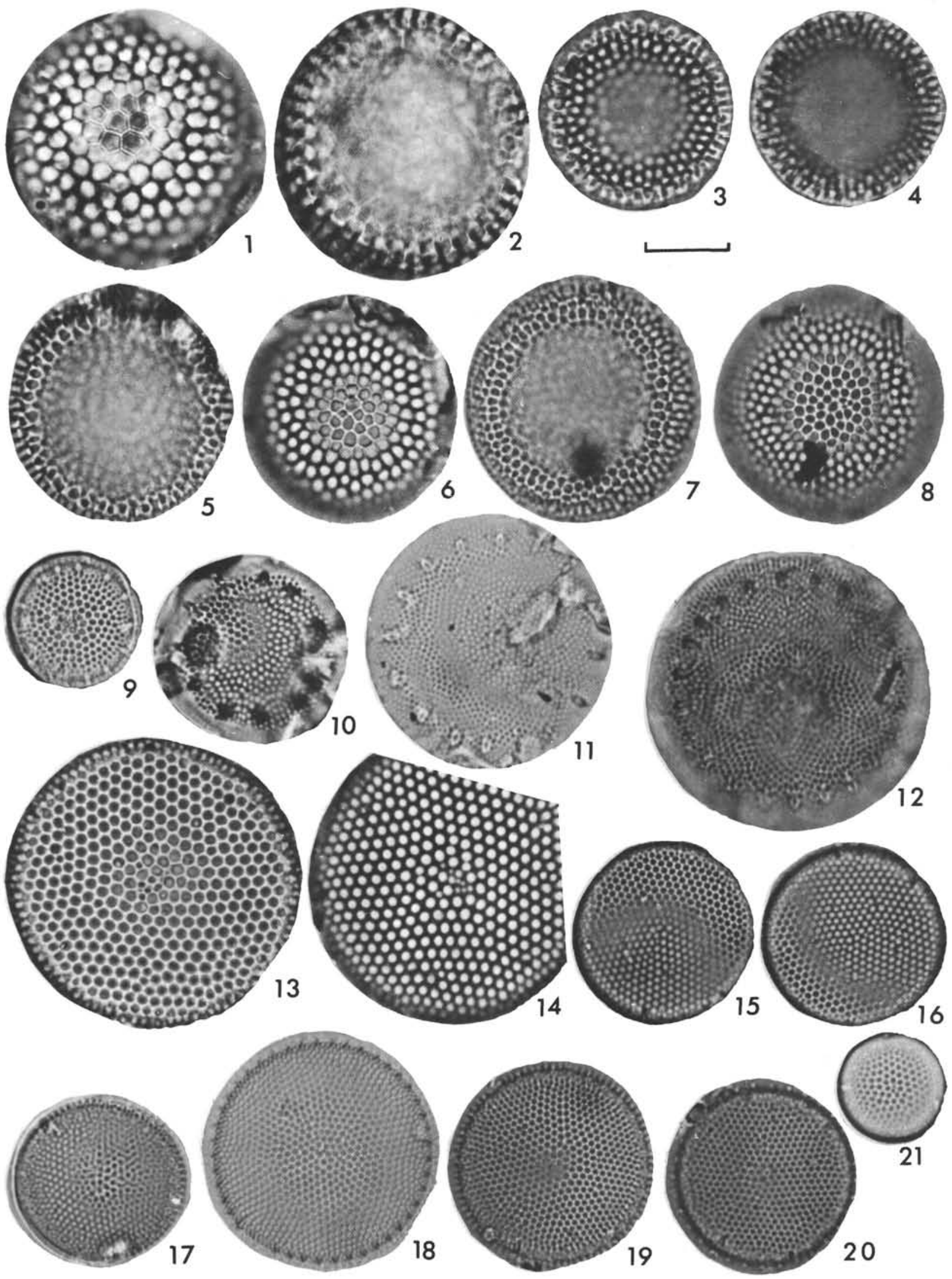
PLATE 15

Magnification $1500 \mathrm{X}$

Figures 1-7 Stephanopyxis turris RALFS.

(1) DSDP 173-13-1(55-56); (2) DSDP 173-13-1(55-56);

(3) DSDP 178-16-3(114-116); (4) DSDP 173-14-1(55-56);

(5) DSDP 173-14-1(55-56); (6) DSDP 173-1-3(43-44);

(7) DSDP 173-1-3(43-44).

Figure $8 \quad$ Stephanopyxis kulmii nov. spec. DSDP 173-1-3(43-44).

Figures 9-11 Stephanopyxis dimorpha nov. spec. (type).

(9) DSDP 173-1-4(114-115); (10) DSDP 173-1-4(114-115);

(11) DSDP 173-1-4(114-115).

Figure 12 Stephanopyxis kulmii nov. spec. (type). DSDP 173-2-2(43-44).

Figures 13,14 Stephanopyxis californica. nov. spec. (13) DSDP 173-10-6(55-56); (14) DSDP 173-10-6(55-56).

Figures 15-17 Stephanopyxis californica nov. spec. (type).

(15) DSDP 173-4-3(55-56); (16) DSDP 173-1-2(13-44);

(17) DSDP 173-1-2(43-44).

Figure $18 \quad$ Stephanopyxis californica $\mathrm{n}$. sp. (lower valve). DSDP 173-1-2(43-44).

Figures 19,20 Stephanopyxis dimorpha nov. spec. (lower valve). (19) DSDP 173-1-2(43-44); (20) DSDP 173-1-2(43-44). 
PLATE 15
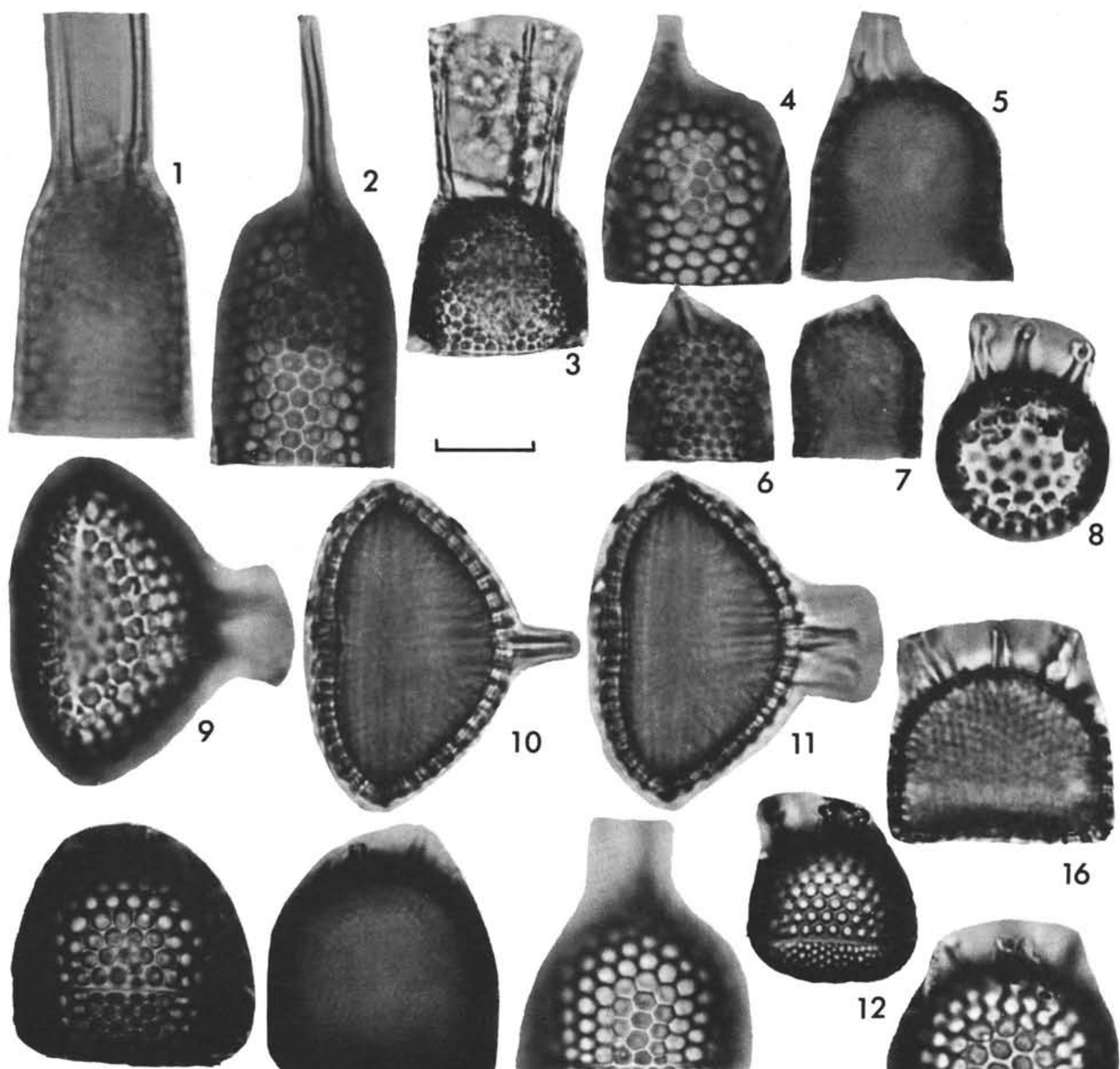

13
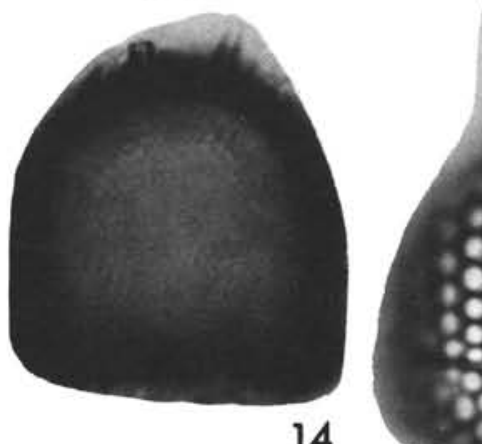

14
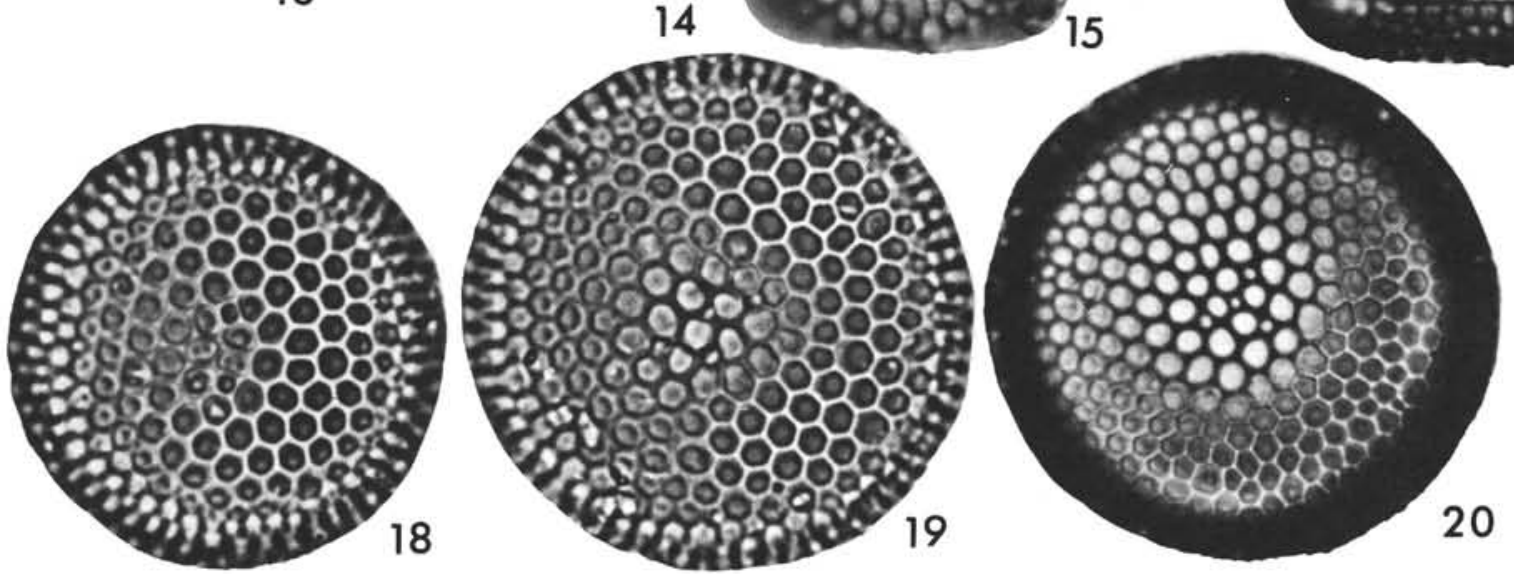

17 
PLATE 16

Magnification 1500X

Figures 1-3 Stephanopyxis dimorpha nov. spec. (upper valve).

(1) DSDP 173-1-1(119-120); (2) DSDP 173-1-2(43-44);

(3) DSDP 173-2-2(43-44).

Figure $4 \quad$ Stephanopyxis kulmii (lower valve) nov. spec. DSDP 173-19-2(55-56).

Figures 5,6 Thalassiosira cf. excentrica.
(5) DSDP 173-19-2(55-56);
(6) DSDP 173-18-2(55-56).

Figure 7

Bacterosira fragilis GRAN. DSDP 178-8-4(100-101).

Figures 8-11 Stephanopyxis dimorpha nov. spec. (upper valve).

(8) DSDP 173-1-3(43-44); (9) DSDP 173-1-3(43-44);

(10) DSDP 173-2-4(42-43); (11) DSDP 173-2-4(42-43).

Figure 12 Thalassiosira decipiens (?) JOERG.

DSDP 173-18-3(56-57).

Figure 13 Stephanopyxis californica n. sp. (lower valve).

DSDP 173-1-3(105-106).

Figure 14 Thalassiosira oestrupii PROSK.-LAV.

DSDP 181-2-3(21-23). 
PLATE 16
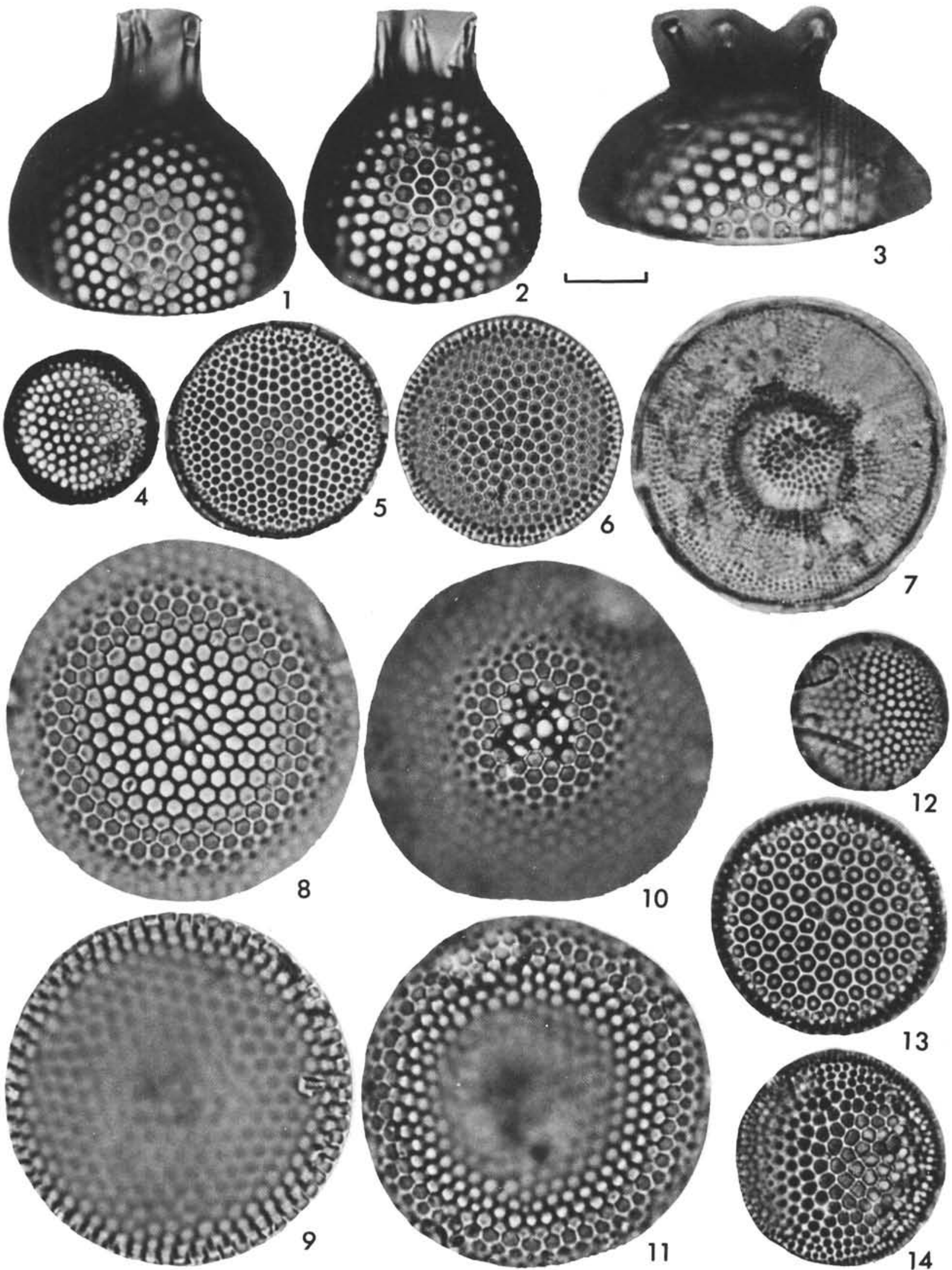
PLATE 17

Magnification 1500X

Figures 1-3 Dicladia pylea HANNA and GRANT.

(1) DSDP 173-11-4(55-56); (2) DSDP 173-14-1(55-56);

(3) DSDP 173-8-1(60-61).

Figure 4 Chaetoceros subsecundus HUSTEDT. DSDP 173-2-2(105-106).

Figures 5-7 Chaetoceros spec. (spore).

(5) DSDP 173-21-1(55-56); (6) DSDP 173-2-2(105-106;

(7) DSDP 173-2-2(43-44).

Figure 8 Chaetoceros subsecundus HUSTEDT. DSDP 173-2-4(104-105).

Figures 9-11 Chaetoceros spec. (spore).

(9) DSDP 173-1-2(109-110); (10) DSDP 173-2-2(105-106);

(11) DSDP 173-2-4(42-43).

Figure 12 Chaetoceros debilis CLEVE (spore). DSDP 173-4-3(55-56).

Figure 13 Chaetoceros debilis CLEVE. DSDP 173-3-6(55-56).

Figure 14 Chaetoceros spec. (spore). DSDP 173-28-2(4-5).

Figure $15 \quad$ Chaetoceros cinctus GRAN (spore). DSDP 173-2-2(105-106).

Figures 16, 17 Thalassiosira spec. 5. SCHRADER.

(16) DSDP 173-18-3(56-57); (17) DSDP 173-18-3(56-57).

Figures 18, 19 Thalassiosira oestrupii PROSK.-LAV.

(18) DSDP 173-18-3(56-57); (19) DSDP 173-18-3(56-57).

Figure $20 \quad$ Thalassiosira punctata JOUSE. DSDP 182-3-1(90-92).

Figures 21-23 Thalassiosira spec. 6. SCHRADER.

(21) DSDP 173-4-2(55-56); (22) DSDP 173-4-2(55 56);

(23) DSDP 173-4-2(55-56).

Figures 24, 25 Thalassiosira oestrupii PROSK.-LAV.

(24) DSDP 173-18-3(56-57); (25) DSDP 173-18-3(56-57). 
PLATE 17

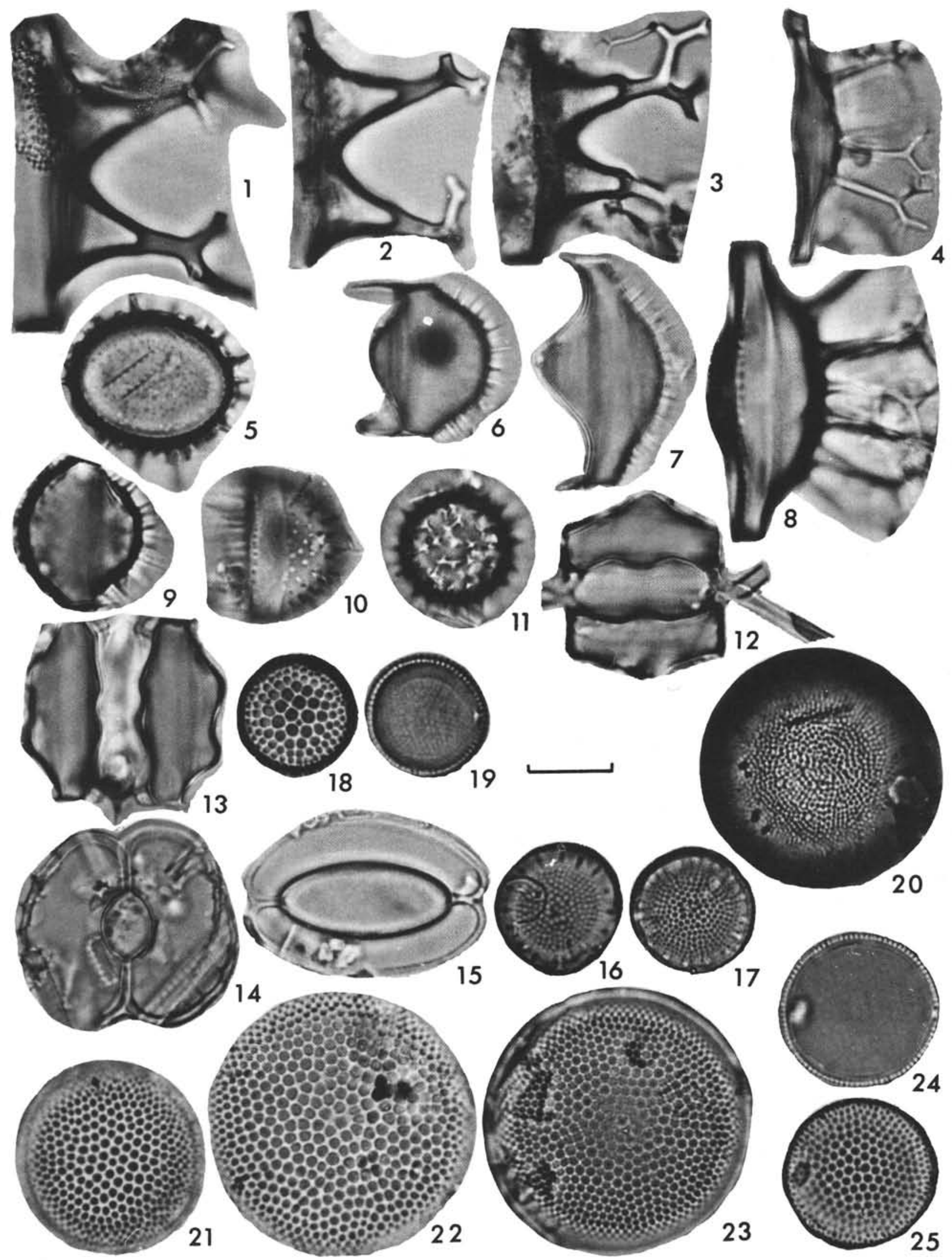


PLATE 18

Magnification 1500X

Figures 1.4 Actinocyclus ingens RATT.

(1) DSDP 173-29-2(57-59); (2) DSDP 173-24-1(105-106);

(3) DSDP 173-27-1(107-108); (4) DSDP 173-29-2(57-59).

Figures 5,6 Actinocyclus oculatus JOUSÉ.

(5) DSDP 178-12-1(112-114); (6) DSDP 178-12-1(112-114).

Figure $7 \quad$ Actinocyclus ingens RATT. DSDP 178-52(CC).

Figure 8 Actinocyclus ochotensis JOUSÉ. DSDP 173-18-2(55-56).

Figures 9-14 Actinocyclus oculatus JOUSÉ.

(9) DSDP 178-10-2(45-47); (10) DSDP 178-19-3(119-121);

(11) DSDP 178-18-2(45-47); (12) DSDP 178-16-2(41-43);

(13) DSDP 178-20-3(69-71); (14) DSDP 178-10-2(45-47).

Figure 15 Actinocyclus ochotensis JOUSÉ(?). DSDP 173-4-3(55-56).

Figure 16 Actinocyclus oculatus JOUSÉ. DSDP 178-9-3(100-102).

Figure 17 Actinocyclus ochotensis JOUSÉ. DSDP 178-10-2(45-47).

Figure 18 Actinocyclus oculatus JOUSÉ. DSDP $182-4(C C)$. 
PLATE 18
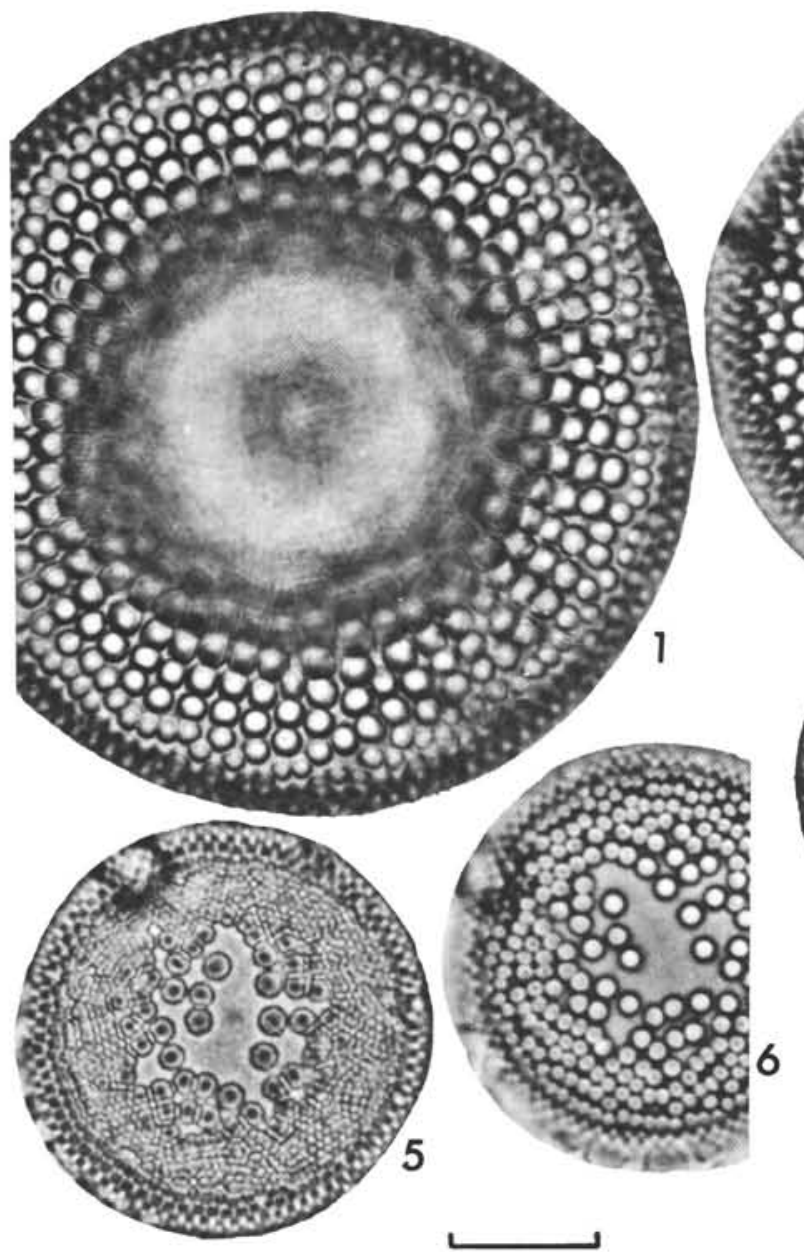
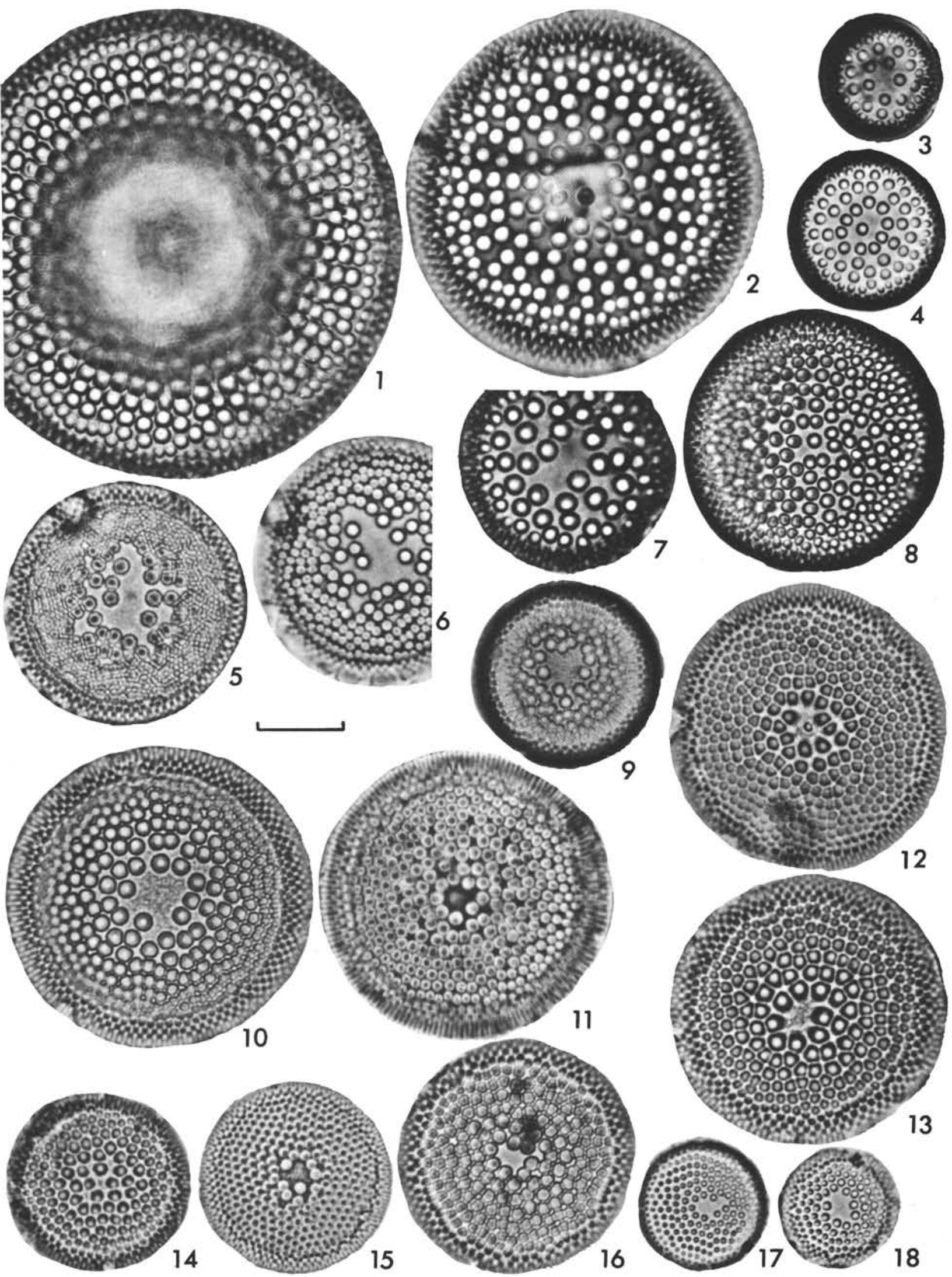
PLATE 19

Magnification 1500X

Figure 1 Actinocyclus ehrenbergii RALFS. DSDP 173-19-2(55-56).

Figure 2 Actinocyclus curvatulus JANISCH. DSDP 173-18-2(55-56).

Figures 3, 4 Roperia tesselata (ROPER) GRUN.

(3) DSDP 173-1-2(43-44); (4) DSDP 173-1-3(43-44).

Figure $5 \quad$ Actinocyclus oculatus JOUSÉ. DSDP 178-19-3(119-121).

Figure 6 Actinocyclus ochotensis JOUSÉ. DSDP 173-4-2(55-56).

Figure 7 Actinocyclus cubitus HANNA and GRANT. DSDP 173-29-2(57-58).

Figures 8,9 Roperia tesselata (ROPER) GRUN.

(8) DSDP 173-1-1(119-120); (9) DSDP 173-1-1(119-120). 
PLATE 19
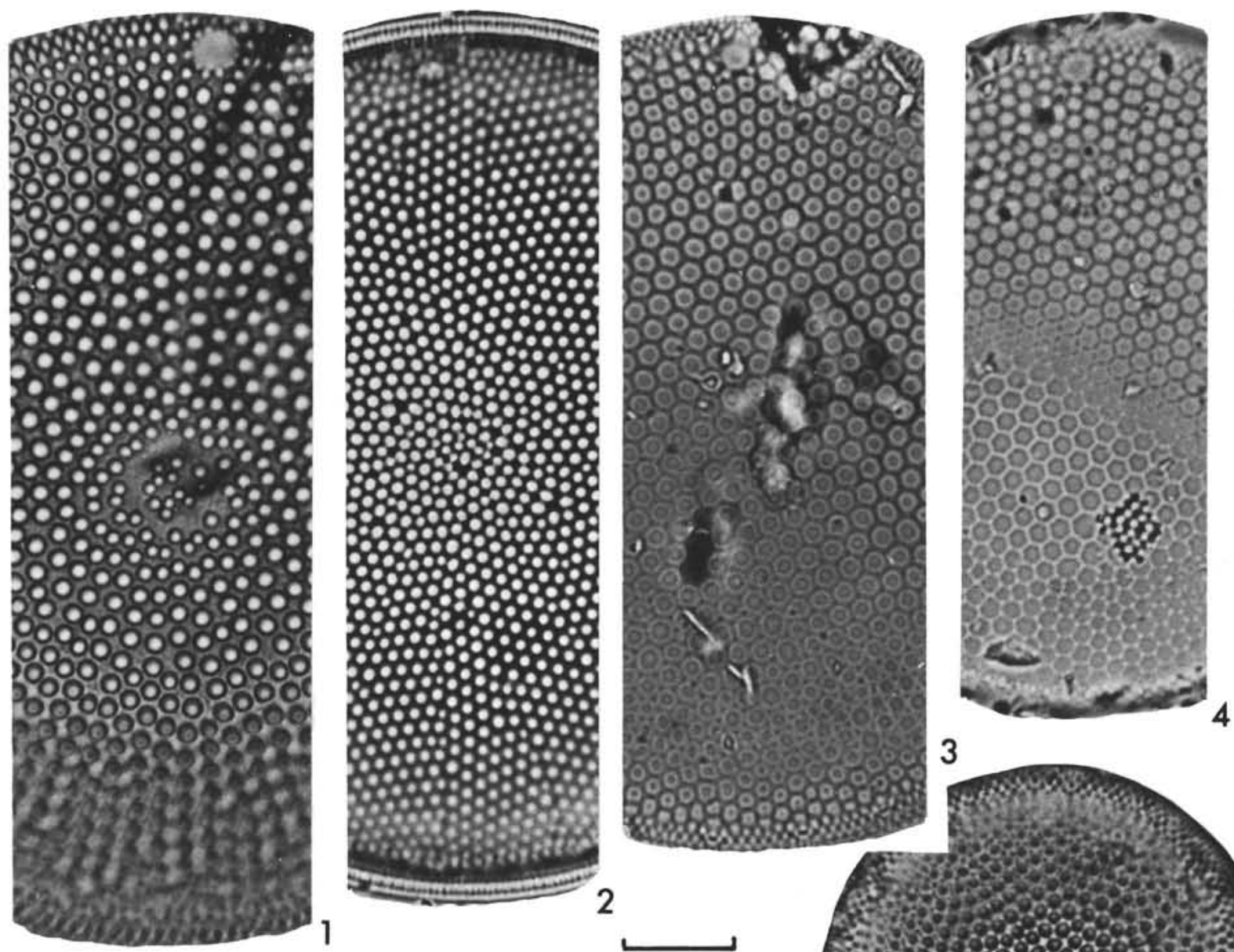

3
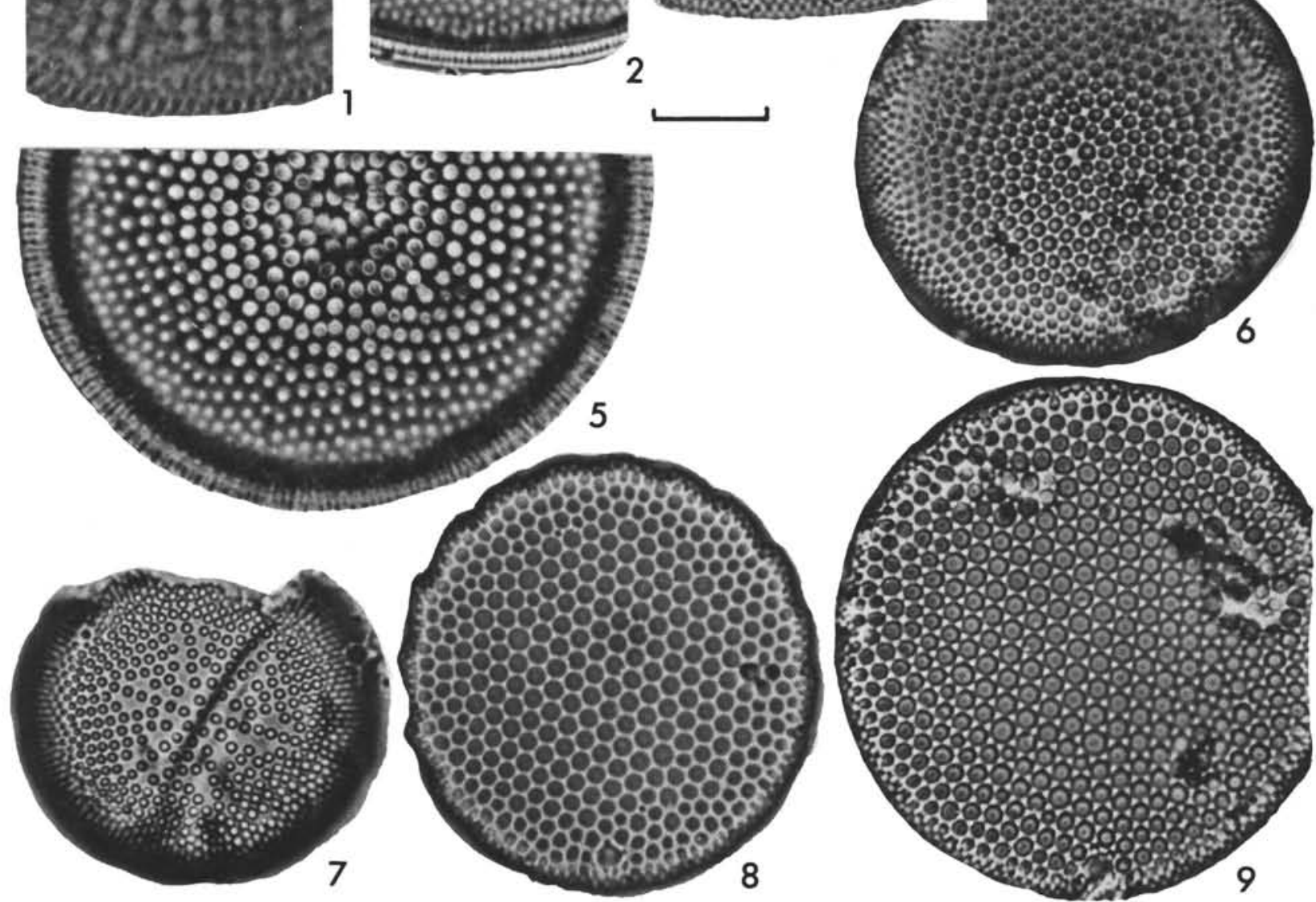
PLATE 20

Magnification 1500X

Figures 1, 2 Coscinodiscus endoi KANAYA.

(1) DSDP 173-25-1(95-96); (2) DSDP 173-20-2(55-56);

Figures 3, 4 Coscinodiscus tabularis GRUNOW var. egregius HUSTEDT.

(3) DSDP 173-1-1(119-120); (4) DSDP 178-6-4(120-122).

Figure $5 \quad$ Coscinodiscus antiquum PANT.

DSDP 173-30(CC).

Figure $6 \quad$ Craspedodiscus coscinodiscus EHR. DSDP 173-21-4(55-56).

Figure $7 \quad$ Coscinodiscus marginatus EHR. DSDP 178-52(CC).

Figure $8 \quad$ Gen. et spec. indet. DSDP $175-18(C C)$.

Figure 9 Melosira sulcata (EHR.) KUETZ. DSDP 173-1-2(43-44).

Figure 10 Coscinodiscus marginatus EHR. DSDP 173-26-1(120-121).

Figure $11 \quad$ Endictya oceanica EHR. DSDP 173-1-2(109-110).

Figures 12,13 Coscinodiscus marginatus EHR. forma fossilis JOUSÉ. (12) DSDP 173-26-1(120-121); (13) DSDP 175-18(CC). 
PLATE 20

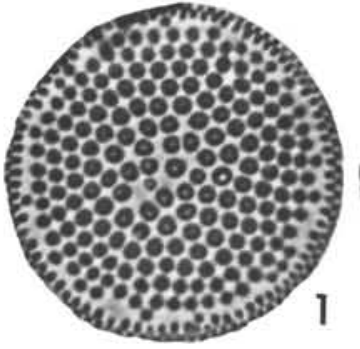

Actersion.

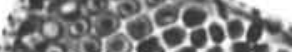

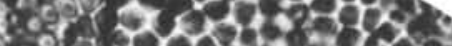

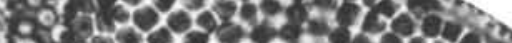

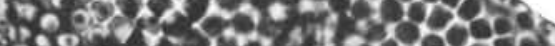

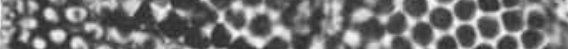

Yos

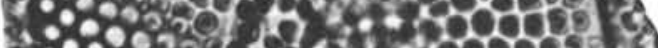

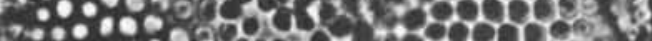

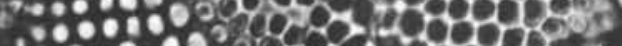

'8\%:0\%

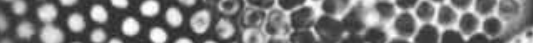

\%oge?

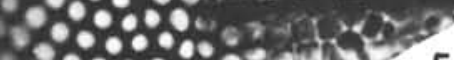

- o.eos 5

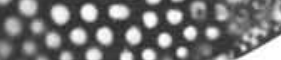

a.e.

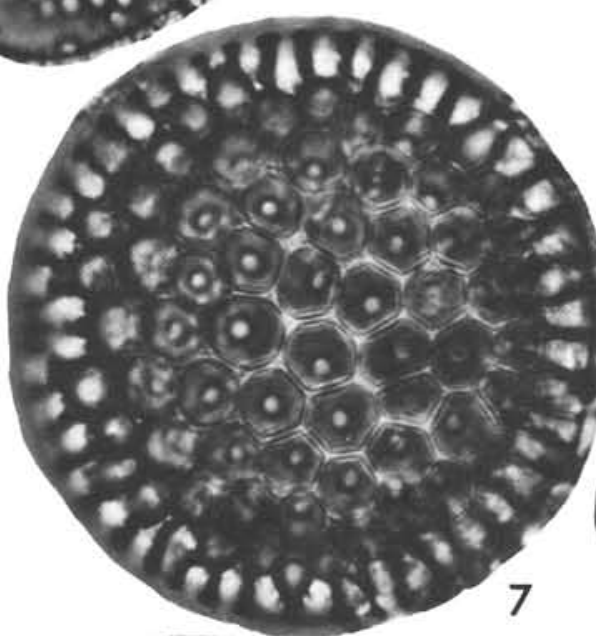

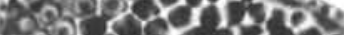

ivo s
2

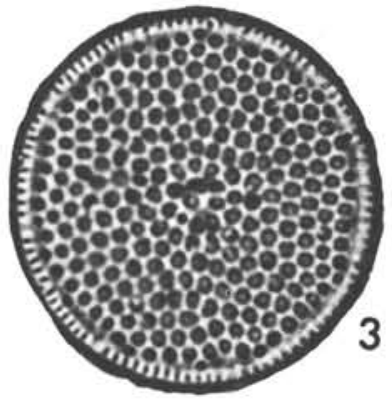

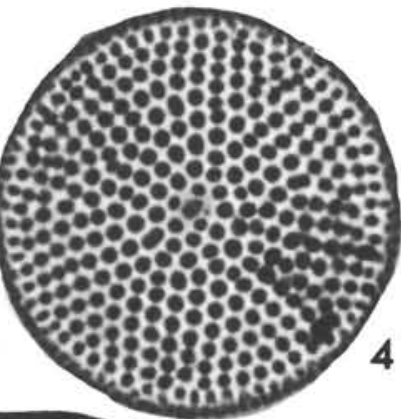

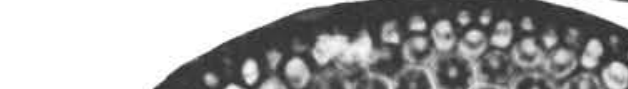

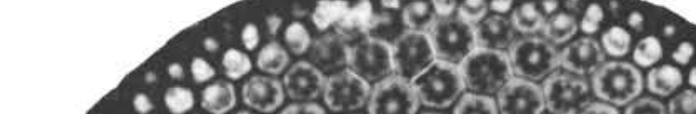

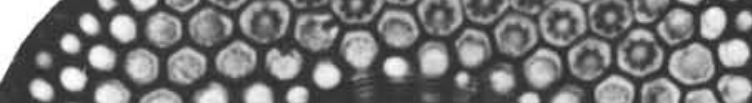
90000

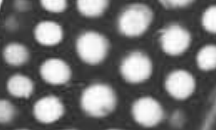

CPe

$\mathrm{COP}_{\mathrm{O}}$

ती०

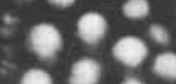

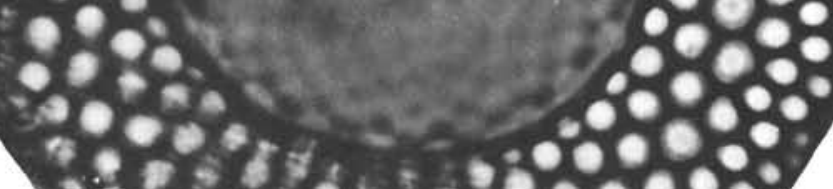

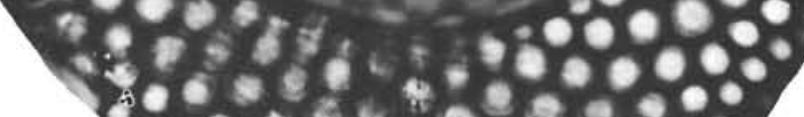

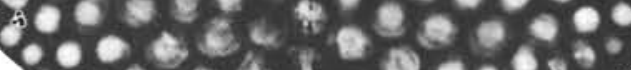
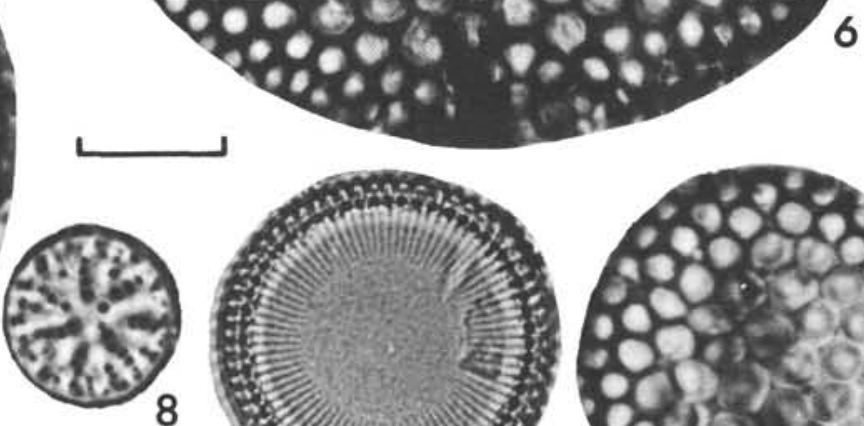

8

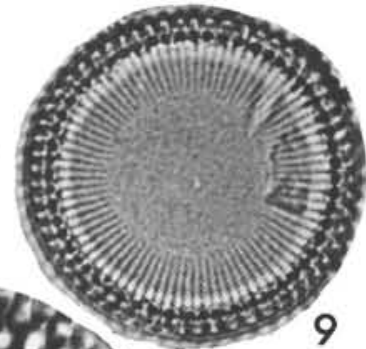

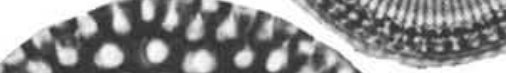
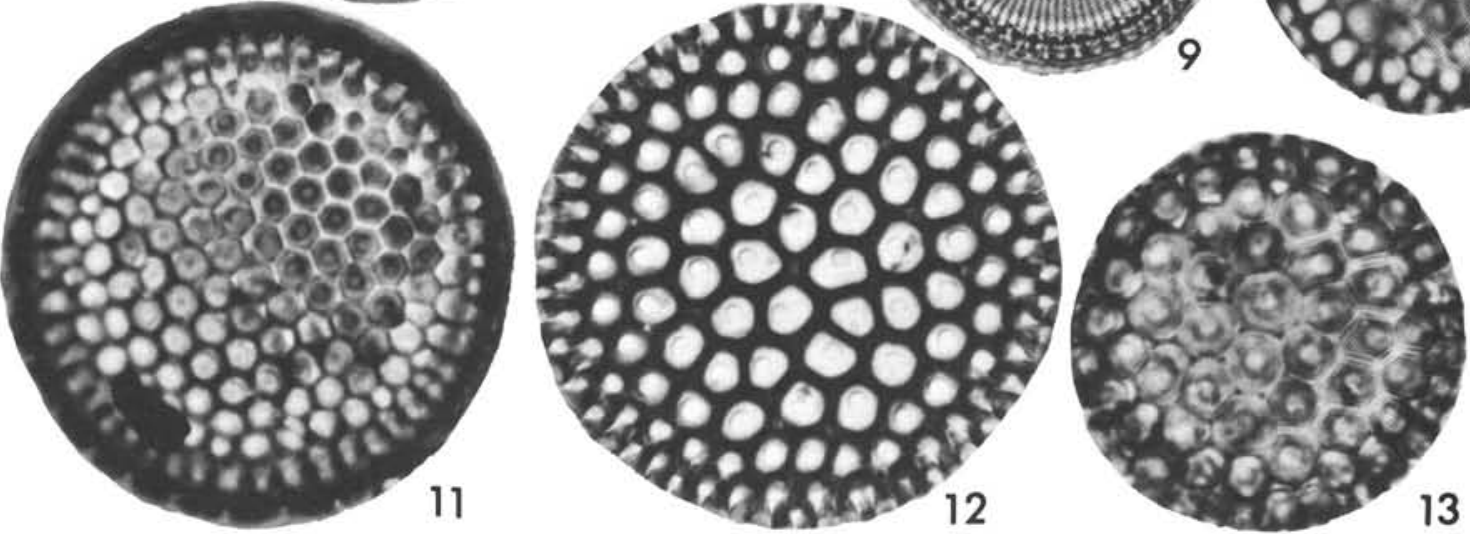

10 
PLATE 21

Magnification 1500X

Figure 1 Asteromphalus robustus CASTRAC. DSDP 173-18-2(55-56).

Figure 2 Asterolampra marylandica EHR. DSDP 173-2-2(43-44).

Figure 3 Asterolampra grevillei (WALL.) GREV. DSDP 173-1-1(119-120).

Figures 4, $5 \quad$ Asteromphalus robustus CASTRAC.

(4) DSDP 178-20-2(110-112); (5) DSDP 173-8-1(60-61).

Figure $6 \quad$ Asteromphalus hookeri EHR. DSDP 173-4-3(55-56).

Figure 7 Asteromphalus $\mathrm{cf}$. robustus CASTRAC. DSDP 173-20-3(55-56).

Figure $8 \quad$ Asterolampra spec. 1 SCHRADER. DSDP 173-20-3(55-56). 
PLATE 21
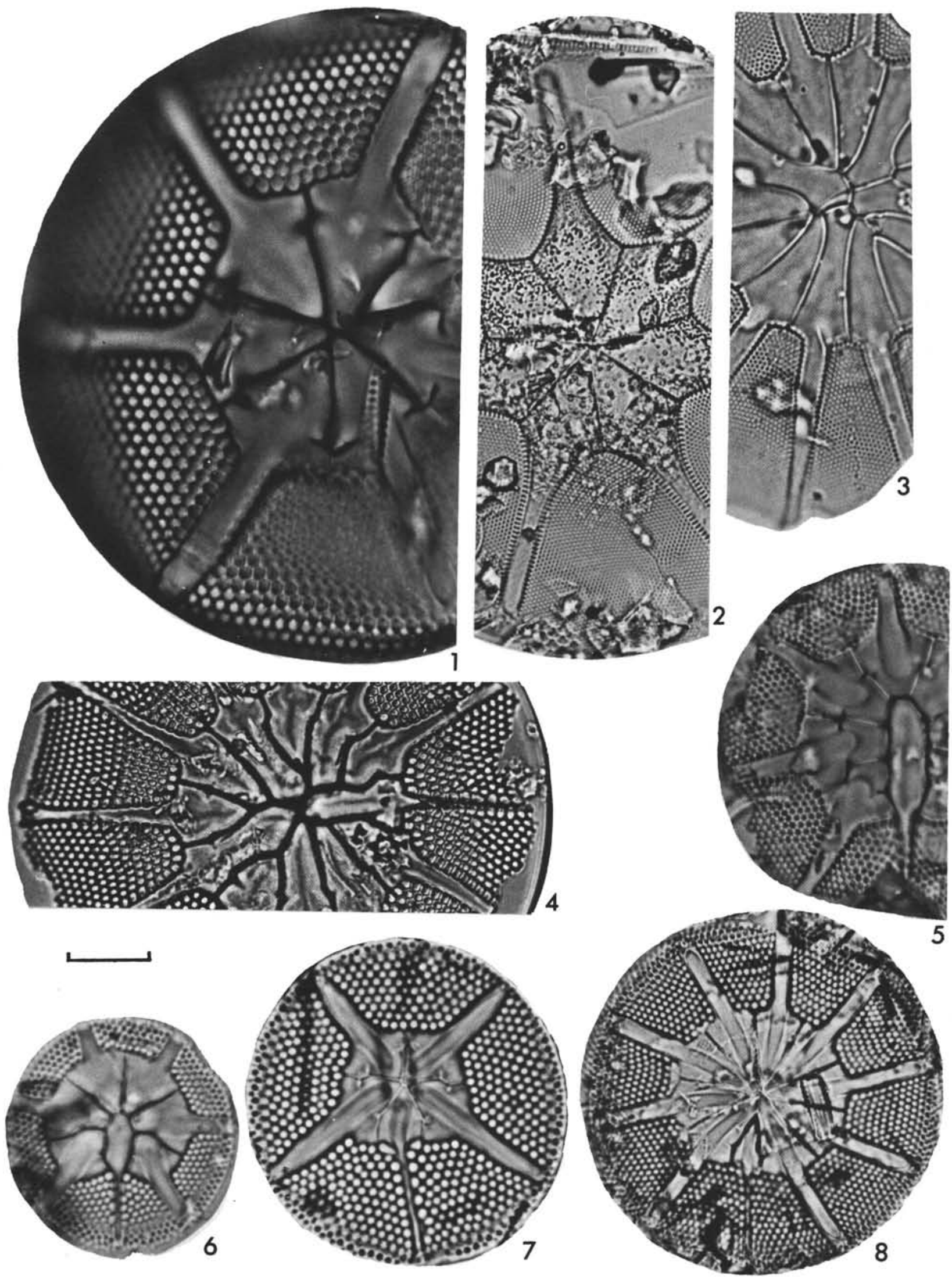
PLATE 22

Magnification 1500X

Figure 1 Actinoptychus splendens (SHADB.) RALFS. DSDP 173-19-2(55-56).

Figure 2 Coscinodiscus vetustissimus PANT. DSDP 173-15-4(55-56).

Figure 3 Coscinodiscus stellaris ROPER. (900X). DSDP 173-19-2(55-56).

Figures 4, 5 Actinoptychus undulatus (BAIL.) RALFS.

(4) DSDP 173-1-2(43-44); (5) DSDP 173-29-2(57-59).

Figure $6 \quad$ Glyphodiscus stellatus GREV. DSDP 173-23-2(55-56).

Figure 7 Raphidodiscus marylandicus CHRIST. DSDP 173-29-2(57-59).

Figures 8,9 Coscinodiscus symbolophorus GRUN.

(8) DSDP 173-30(CC); (9) DSDP 173-30(CC).

Figure 10 Actinoptychus cf. splendens (SHADB.) RALFS. DSDP 173-4-2(55-56).

Figure 11 Actiniptychus $\mathrm{cf}$. splendens (SHADB.) RALFS. DSDP 173-3-6(55-56).

Figure 12 Actinoptychus undulatus (BAIL.) RALFS. DSDP 173-1-3(43-44).

Figures 13, 14 Actinoptychus cf. splendens RALFS.

(13) DSDP 173-4-2(55-56); (14) DSDP 178-12-1(112-114).

Figure $15 \quad$ Actinoptychus undulatus RALFS. DSDP 173-2-5(63-64).

Figure 16 Actinoptychus splendens RALFS. DSDP 173-2-1(103-104).

Figure 17 Actinoptychus cf. undulatus RALFS (?) DSDP 173-2-5(65-66). 
PLATE 22

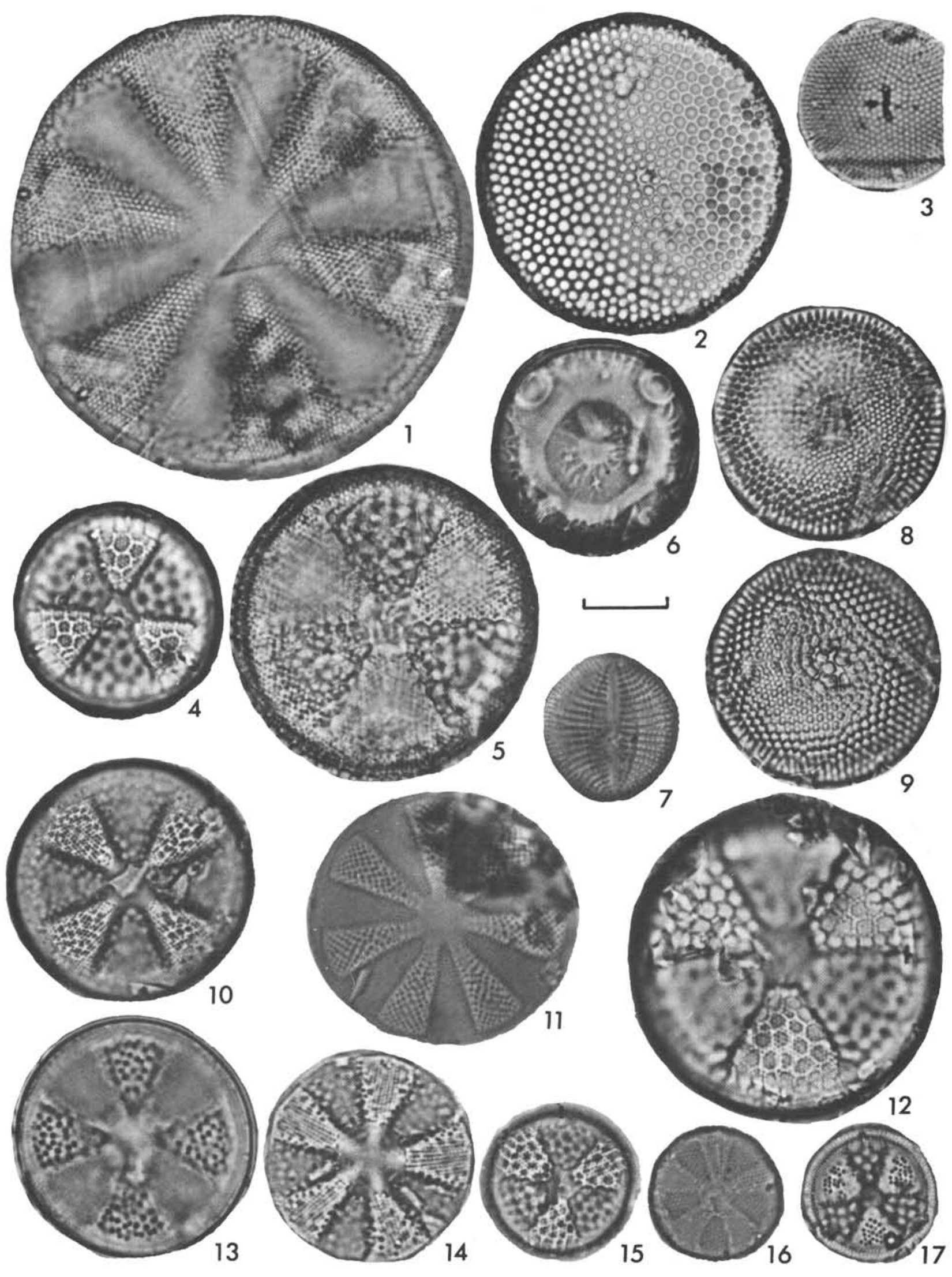


PLATE 23

Magnification 1500X

Figure 1

Figures 2-5

Figure 6

Figure 7

Figures 8-10

Figure 11

Figures 12,13

Figure 14

Figure 15

Figure 16

Figures 17,18

Figure 19

Figure 20

Figures 21-23

Figure 24

Figure 25

Figures 26-30

Figures 31-33

Figure 34

Figures 35-37

Figure 38
Thalassionema nitzschioides GRUN. DSDP 173-1-1(119-120)
Thalassiothrix miocenica nov. spec. (type.)
(2) DSDP 173-25-1(95-56); (3) DSDP 173-25-1(35-36);
(4) DSDP 173-25-1(35-36); (5) DSDP 173-25-1(35-36).

Thalassionema nitzschioides GRUN. DSDP 173-1-4(55-56).

Thalassiothrix longissima CLEVE AND GRUN. DSDP 181-1-6(78-80).

Thalassionema nitzschioides GRUN.

(8) DSDP 173-19-2(55-56); (9) DSDP 181-2-3(21-23);

(10) DSDP 173-14-1(55-56).

Thalassionema claviformis nov. spec. (type). DSDP 173-23-2(55-56).

Thalassionema nitzschioides GRUN.

(12) DSDP 173-21-1(55-56); (13) DSDP 173-21-1(55-56).

Thalassionema lineatum JOUSÉ. DSDP $173-15-4(55-56)$

Thalassionema claviformis nov. spec. DSDP 173-21-1(55-56).

Thalassionema nitzschioides GRUN. DSDP 173-29-2(57-59).

Thalassiothrix longissima CLEVE and GRAN.

(17) DSDP 178-40(CC). (18) DSDP 178-54-2(26-27).

Thalassionema nitzschioides GRUN. DSDP $173-1-4(114-115)$.

Rhaphoneis sachalinensis SHESH.-POR. DSDP 173-16-1(69-70).

Synedra jouseana SHESH.-POR.

(21) DSDP 173-29(CC); (22) DSDP 173-29(CC);

(23) DSDP 173-16-1(69-70).

Thalassionema robusta nov. spec. (type). DSDP 178-37-2(39-41).

Synedra jouseana SHESH.-POR. DSDP 173-29(CC).

Thalassionema antiqua (nov. spec.).

(26) DSDP 178-54-2(26-27); (27) DSDP 178-54-2(26-27);

(28) DSDP 178-54-2(26-27); (29) Type; DSDP 178-54-2(26-27)

(30) DSDP 178-54-2(26-27).

Thalassionema hirosakiensis (KANAYA) nov. comb.

(31) DSDP 173-16-1(69-70); (32) DSDP 173-16-1(69-70).

(33) DSDP 178-52(CC).

Thalassionema nitzschioides GRUN. DSDP 181-1-6(78-80).

Thalassionema robusta nov. spec.

(35) DSDP 178-37(CC); (36) DSDP 173-16-1(69-70).

(37) DSDP 173-29-2(57-59).

Synedra jouseana SHESH-POR. DSDP 173-21-4(55-56). 
PLATE 23

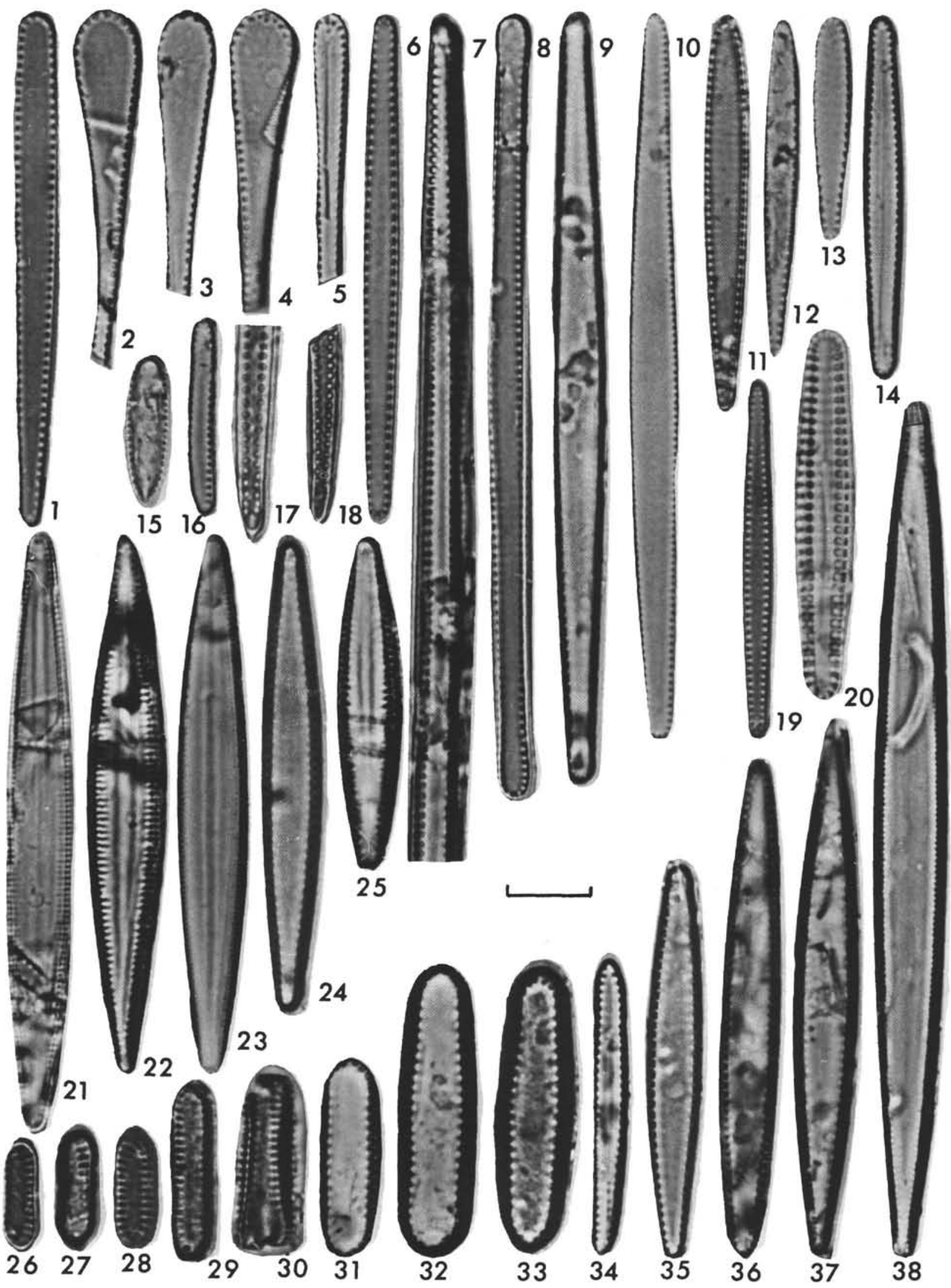




\section{PLATE 24}

Magnification 1500X

Figures 1-3 Rhizosolenia praebarboi nov. spec. (type).

(1) DSDP 173-22-1(10-11); (2) DSDP 173-21-1(55-56);

(3) DSDP 173-26-1(120-121).

Figure 4 Rhizosolenia barboi BRUN. DSDP 173-2-4(42-43).

Figures 5,6 Rhizosolenia curvirostris JOUSÉ.

(5) DSDP 173-8-1(60-61); (6) DSDP 173-8-1(60-61).

Figure $7 \quad$ Rhizosolenia barboi BRUN. DSDP 173-2-3(119-120).

Figures 8, 9 Rhizosolenia curvirostris JOUSÉ.

(8) 900X; DSDP 178-3-3(120-122);

(9) DSDP 178-16-3(6-8).

Figure 10 Stephanopyxis dimorpha nov. spec. (lower valve). DSDP 173-11-1(55-56).

Figure 11 Cladogramma dubium LOHMANN. DSDP 173-17-3(103-104).

Figures 12,13 Hemidiscus simplicissimus HANNA and GRANT.

(12) DSDP 173-18-3(56-57); (13) DSDP 173-16-1(69-70):

Figure 14 Hemidiscus suneiformis WALL. DSDP 173-1-3(43-44).

Figure $15 \quad$ Actinocyclus ellipticus var. moronensis KOLBE (?). DSDP 173-15-3(55-56). 
PLATE 24

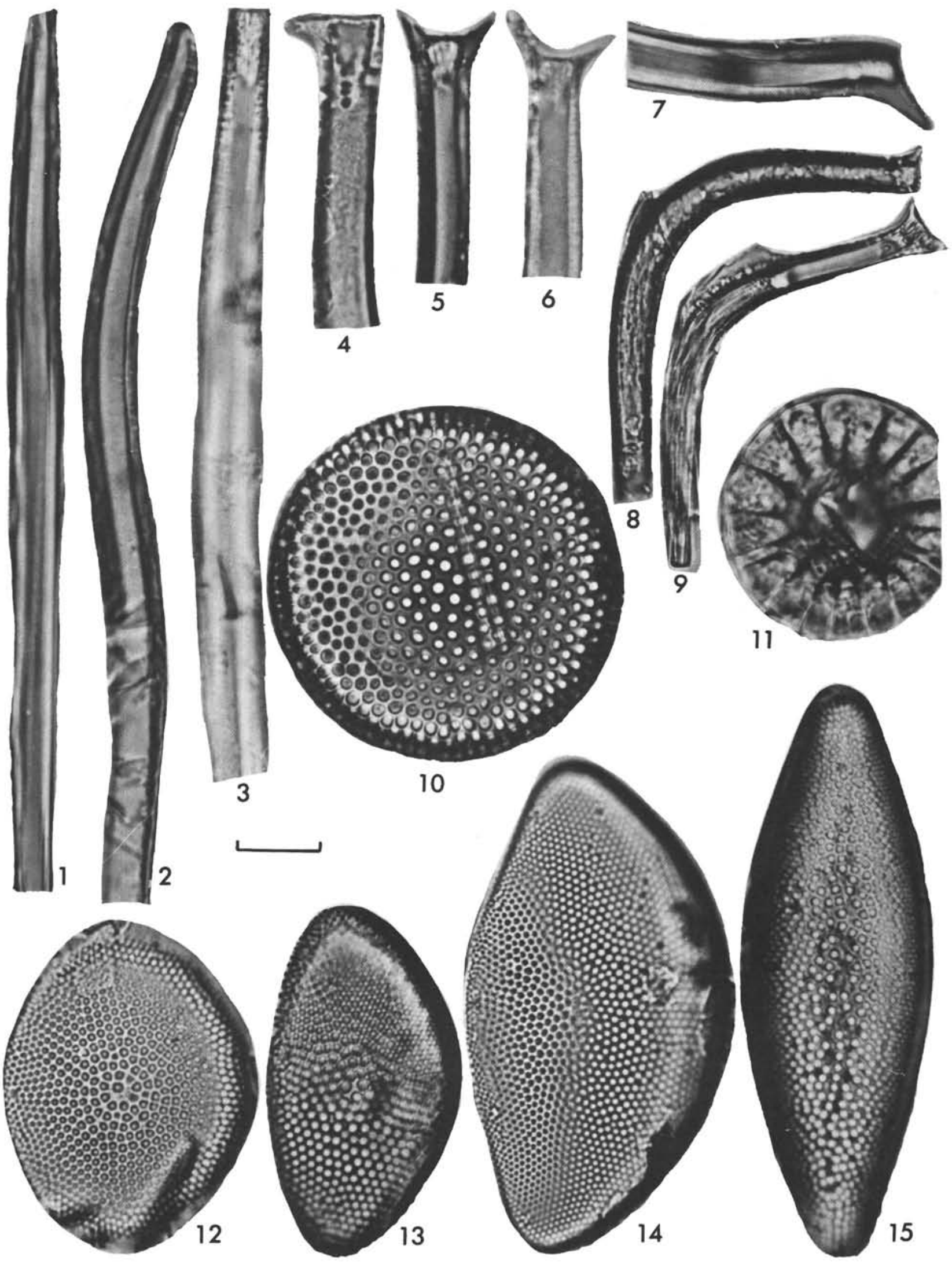


PLATE 25

Magnification 1500X

Figure $1 \quad$ Rhaphoneis miocenica nov. spec. (type).

DSDP 173-30(CC).

Figures 2, 3 Rhaphoneis amphiceros EHR.

(2) DSDP 173-1-1(119-120); (3) DSDP 173-1-2(109-110).

Figure 4 Rhaphoneis surirella GRUN.

DSDP 173-15-2(55-56).

Figure $5 \quad$ Rhaphoneis sachalinensis SHESH.POR.

DSDP 173-18-2(55-56).

Figure $6 \quad$ Rhaphoneis surirella GRUN.

DSDP 173-1-2(43-44).

Figures 7, 8 Rhaphoneis sachalinensis SHESH.POR.

(7) DSDP 173-3-2(55-56); (8) DSDP 173-10-5(55-56).

Figures 9, 10 Rhaphoneis cocconeides nov. spec.

(9) DSDP 173-26-1(120-121); (10) Type; DSDP 173-3-6(55-56).

Figure $11 \quad$ Rhaphoneis miocenica nov. spec.

DSDP 173-30(CC).

Figure 12 Rhaphoneis surirella. GRUN.

DSDP 178-54-2(16-17).

Figure $13 \quad$ Rhaphoneis margaritalimbata MERTZ.

DSDP 173-13-1(55-56).

Figures 14-16 Rhaphoneis sachalinensis SHESH.POR.

(14) DSDP 173-17-3(103-104); (15) DSDP 178-34(CC);

(16) DSDP 178-34(CC).

Figure 17 Thalassiosira excentrica CLEVE.

DSDP 173-1-4(55-56).

Figure 18 Thalassiosira pacifica GRAN and ANGST.

DSDP 181-2-3(21-23)

Figure 19 Thalassiosira antiqua CLEVE.

DSDP 173-15-2(55-56).

Figures 20,21 Thalassiosira pacifica GRAN and ANGST.

(20) DSDP 181-2-3(21-23); (21) DSDP 181-1-6(78-80).

Figure 22 Nitzschia granulata GRUN. var. hispanica AZPEITIA.

DSDP 173-4-1(54-55).

Figure 23 Lithodesmium pliocenicum nov. spec. (type).

DSDP 173-14-1(55-56). 
PLATE 25

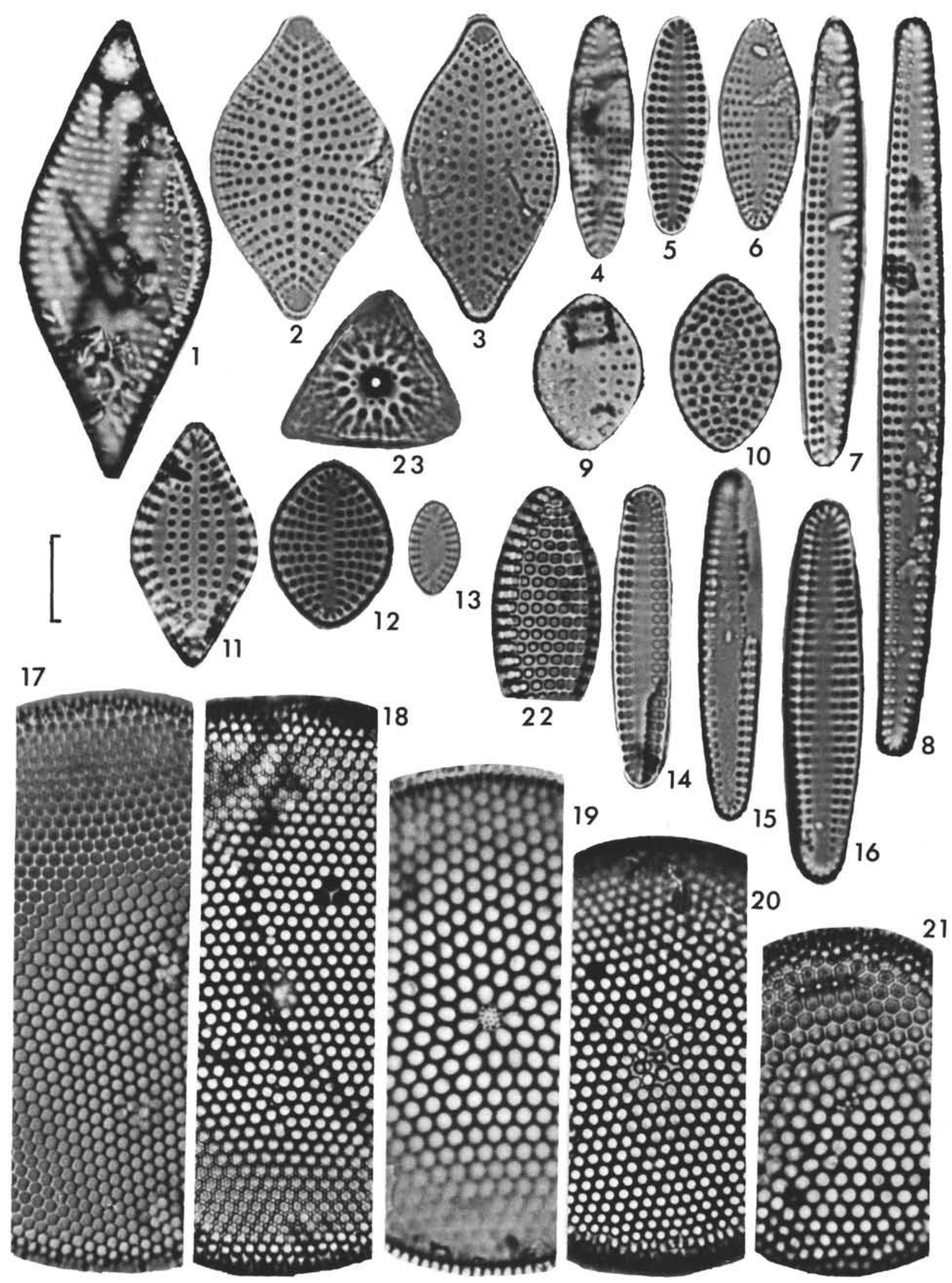


PLATE 26

Magnification 1500X

Figures 1,2 Nitzschia heteropolica nov. spec. (type).

(1) DSDP 173-22-1(55-56); (2) DSDP 173-22-1(55-56).

Figures 3,4 Nitzschia rolandii nov. spec.

(3) DSDP 173-15-2(55-56); (4) DSDP 173-15-2(55-56).

Figure $5 \quad$ Nitzschia invisa nov. spec. (type).

DSDP 173-17-3(103-104).

Figure $6 \quad$ Nitzschia californica nov. spec. (type). DSDP 173-9-3(55-56).

Figure $7 \quad$ Coscinodiscus stellaris ROPER. DSDP 173-17-3(103-104).

Figure $8 \quad$ Cymatogonia amblyoceras HANNA. DSDP 173-30(CC).

Figures 9, 10 Rhaphoneis angularis LOHMANN.

(9) DSDP 173-16-2(55-56); (10) DSDP 173-16-2(55-56).

Figure 11 Pyxilla johnsoniana GREV. DSDP 173-31-1(132-134).

Figure 12 Hemiaulus spec. 3 SCHRADER. DSDP 173-17-3(55-56). 
PLATE 26
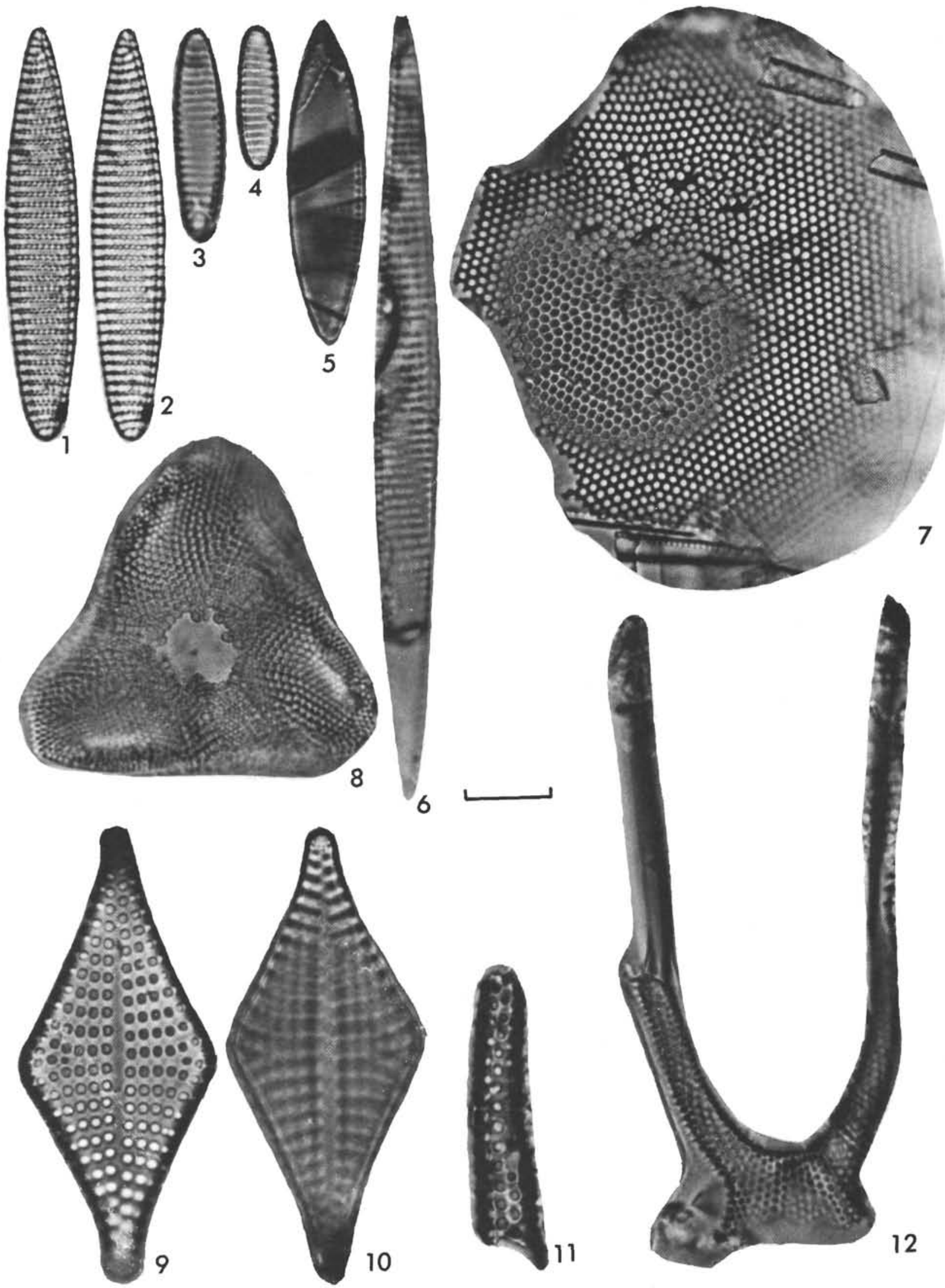